ISBN 978-85-5953-031-5

https://doi.org/10.26626/978-85-5953-031-5.2018B001

\title{
Water Resources Management
}

\section{Takako Matsumura-Tundisi José Galizia Tundisi}

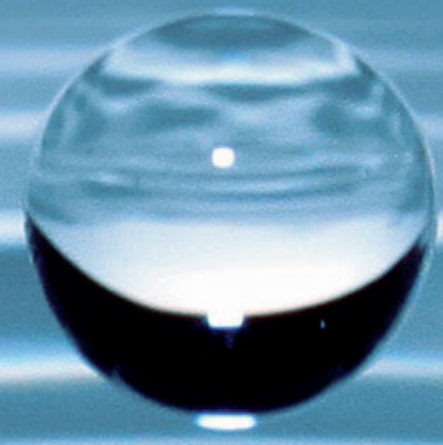

(Editors)
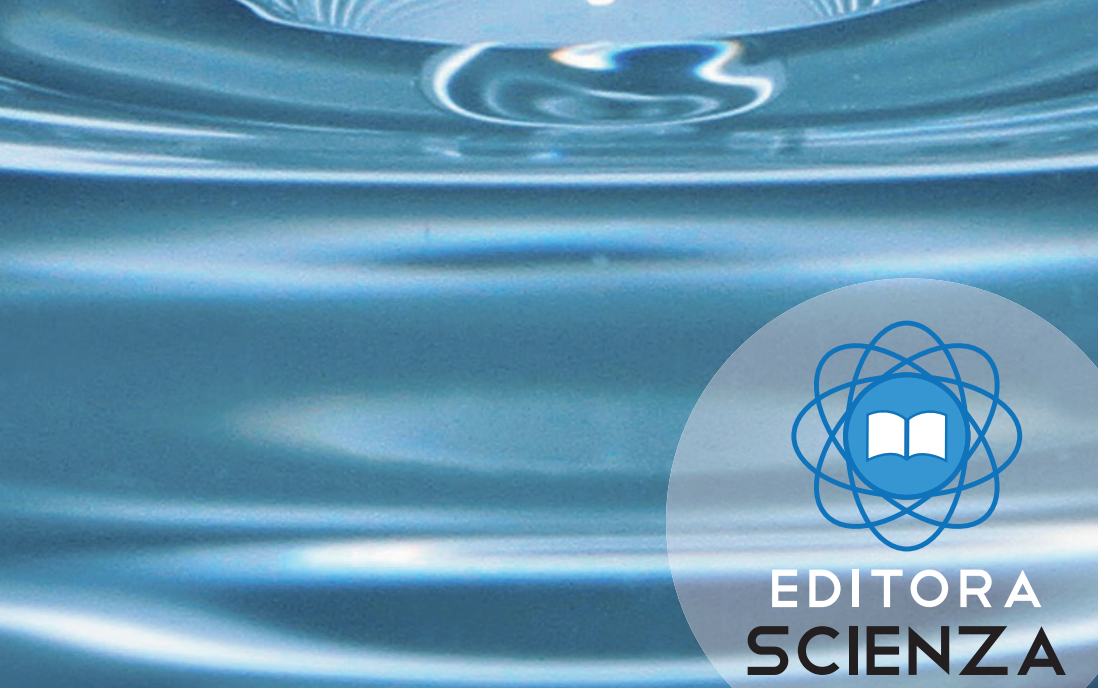



\section{Water Resources Management}

\section{Takako Matsumura-Tundisi J osé Galizia Tundisi (Ed itors)}

São Carlos 2018 



\section{Water Resources Management}

\section{Takako Matsumura-Tundisi J osé Galizia Tundisi (Ed itors)}

São Carlos 2018 
Copyright @ 2018 All rights reserved.

W3242 Water Resources Management / Takako Matsumura-Tundisi, J osé Galizia Tundisi (Editors). São Carlos, 2018.

$248 p$.

ISBN 978-85-5953-031-5

https:// doi.org/ 10.26626/978-85-5953-031-5.2018B001

1. Limnology. 2. Water management technology. 3. Aquatic biodiversity. 4. Pollution control. I. Org. II. Título.

CDD 570

Editoração, Revisão e E-pub:

\section{SCIENZA}

Rua Juca Sabino, 21 - São Carlos, SP

(16) $3364-3346$ | (16) $99285-3689$

www.editorascienza.com.br

gustavo@editorascienza.com 


\section{Acknowledgements}

The Ed itors acknowledge the fina ntial support of FAPESP for this public ation (Process: 2016/18658-0), the Brazilian Academy of Sciences (ABC) and the Inter American Network of Academies of Science (IANAS) which provided support for the SÃO PAULO ADVANCED SC HOOL ON INTEG RATED WATER RESOURCES MANAGEMENT and for this book.
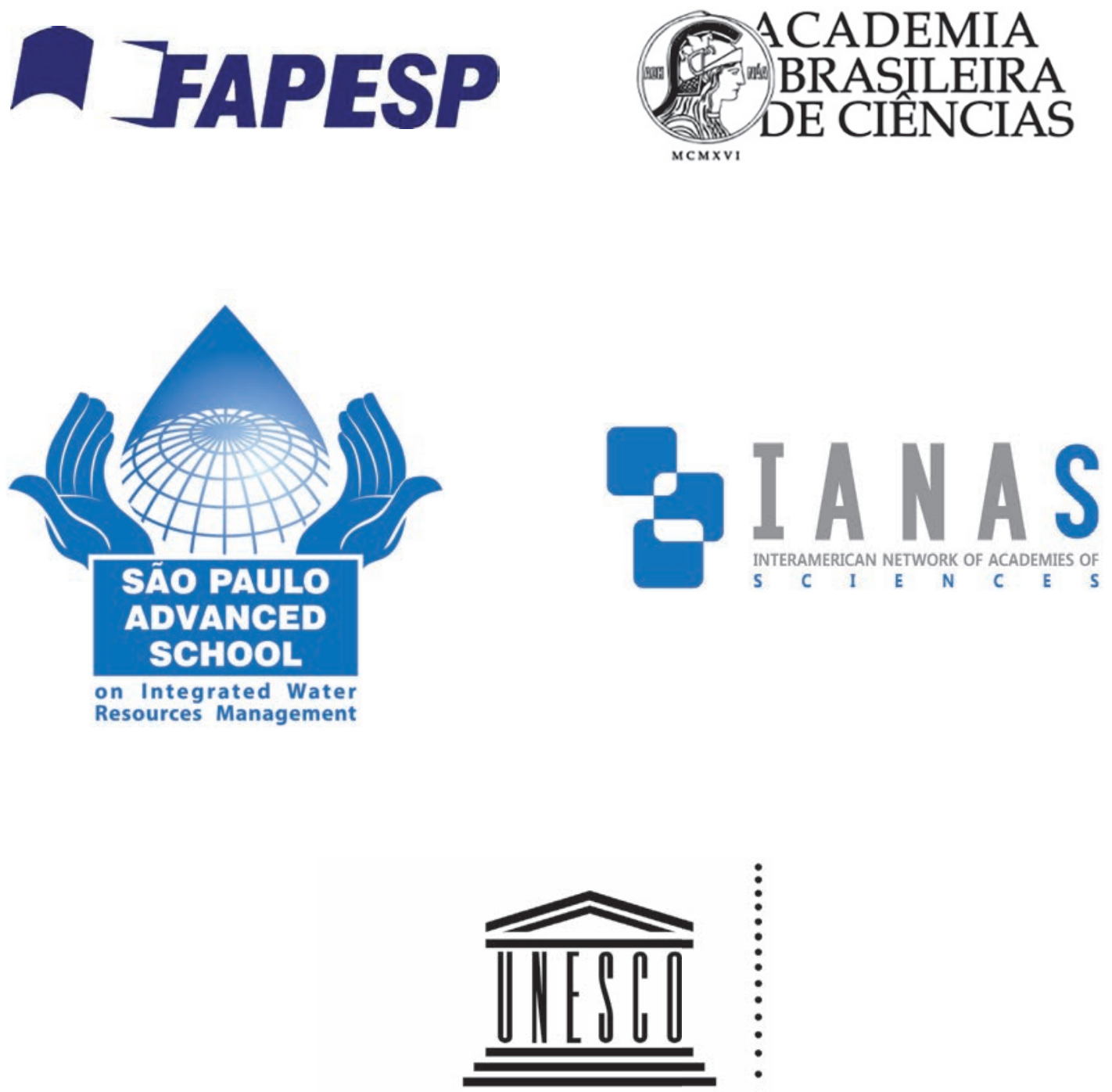

United Nations

Educational, Scientific and

Cultural Organization 
$6 \mid$ 


\section{Contents}

Foreword

11

Preface.

Diatoms as Indic ators of Anthropogenic Changes in Water

Quality in Mucheke and Shaga she Rivers, Masvingo, Zmbabwe.....

Bere, T.; Chakandinakira, A.T.

Analysis of Surface and Ground Water Samples in the Environs of Gold

Mines Linked to Lead Poisoning Incident in Niger State, Nigeria

Adio-Adepoju, A.A., O kiei, W.O., Ogunlesi, M., Ojobe, B.L,

Ibrahim, G.O., Sobowale, O.S.

'Natal' Orange (C itrus sinensis L. Osbeck) Growing Simulation

Model Under Climate $C$ hange Conditions.

Pereira, F.F.S., Queluz, J .G.T.' González, A.M.G.O.' Sánchez-Román, R.M.

Diversity of the Zooplankton (Alpha and Beta) in the Lentic

Environment in the Miranda River Basin (MS, Brazil) 59

Silva, W.M., Zanata, L.H., Roche, K.F., Silva, T.H.P.N., Souza, J ., Severino, L.V., Duarte, J.D., Orikassa, T.N.

Impact Assessment of Water Tra nslocation from the Tuc utunemo River to Camatagua Reservoir (Aragua State, Venezuela).

Matos, M.L, Guajardo, N.

Composition of the Characidae Family (Order: Characiformes, Pisces) in an Andean-Amazonian River, Ca se Study Hacha

River Ba sin (Ca quetá-Colombia)

Remic io-Duque, J .H., Pelaez-Rodriguez, M., Gaspar, S. 
The Fluvial Forests as Indic ators of the Flow and Permanence of Water......

Zambiasio, V.A., Casco, S.L, Neiff, J J .

Geographic al Distribution of Calanoida Species (Copepoda-C rustacea), at 22 UGRHi of São Paulo State - Brazil 99

Matsumura-Tundisi, T., Tund isi, J .G.

Integrated Management Plan for the Itaquir Lobo Watershed and UHE Carlos Botelho (Lobo/Broa) Reservoir.

Tund isi, J .G., Matsumura-Tund isi, T., Tundisi, J .E.

Enhancing Methane Yields by Anaerobic Co-digestion of Sludge with Food Residues.

Aburawaa, A. A., Alrousan, D., Hayek, B.

Improving G lobal Wash Susta ina bility 141 Graydon, R.C.

System of Susta ina bility Ind ic a to rs Applied in River Basin Management. 149

Ba ta Ihã o, A.C.S., Teixeira, D.

The Management of Water Resources as a Factor of Urban Resilience. 159

Corrêa, T.H.P., Teixeira, B.A.N.

Assessment of an in situ Real Time UV/VIS Ba sed Spectrometry System for Chemic al Oxygen Demand Measurement in a Wastewater Anaerobic Treatment Reactor. 167

Hemández. O.A.D., Lisboa, A.M., Cantão, M.P., Possetti, G .R.C., Aisse, M.M. 
Real Time Monitoring of Water Quality in

Supply Pipelines and Ind ustrial Fa cilities.

Calvi, F.A., Ramos, G.P., Tundisi, J .G., G higlieno, F.G.

Prelimina ry Study of a Low-Cost, Ea sily-Implementa ble Altemative for Waterbody Restoration Bertho, G.G.

The Use of Geotec hnologies In the Environmental Vulnera bility Diagnosed in Sustainable Use Conservation Unit 193

Siqueira, H.E., Pereira, G.T., Pissa rra, T.C.T., Valle J unior, R.F., Sa nti, G. L. D., Campos, C.A.A.

World Bank Model Calibration Project with SWATMethodology in Ochomogo River, Nic aragua (1st Stage)

Cordero, M., García, A., Lacayo, N., Ramos, J., Yescas, L.

Using MQual 1.5 Modelling to Assess the Water Quality of a Subtropical Catchment 223 Honda, F.P., Matsumura-Tundisi, T., Tundisi J.G.

The Ec ologic al Dyna mic s of UHE Carlos Botelho (Lobo/Broa) Reservoir: Temporal Changes. 237

Tund isi, J .G ., Matsumura-Tund isi, T. 
10 


\section{Foreword}

One of the priorities of the Water Program of the Interamerican Network of Academies of Sciences (IANAS) is contributing to and organizing capacity building activities for future scientists, managers, and policy-makers on water resource management. Transmitting knowledge to future generations is part of the mission of IANAS as the Science Academies of the Americ as a re concentrated on aiding national govemments and institutions in the respective countries in introducing improved water reso urce management practic es to guarantee the rational and susta inable exploitation of this resource in all of the Americ as and especially in developing countries.

This special c ourse, "Sa o Paulo Advanced School on Integrated Water Resources Management" organized by the International Institute of Ecology (IIE) of Brazil and supported by the Foundation of Support for Research of the State of Sa o Pa ulo (FAPESP) brought to gether 100Msc. or PhD students from different institutiona I origins, universities, NGO 's, govemment and wa ter companies, who were a ll specia lists in different a spects of water resources from 24 different countries of Latin America, North America and Afric a. Top global sc ientists from UNESCO, universities a nd IANAS, a ll spec ia lists from diverse fields of water resource management: wa ter ecosystems, limnology, urban water management, and more were involved as professors. Current special topics on water management such as the relationship between water and other resources (energy, agriculture and food security, mineral extraction), wa ste water reuse and improvement of trea tment systems, the management of a c tua I globa I water quality problems, the importance of the water and susta inable development goals and more were presented in the two weeks.

This course not only had a very rich formative objective but a lso promoted intemational cooperation between students and professors whic $h$ is of utmost importance in a changing world with great needs for new global initiatives in developing effec tive strategies for improving water management. There was active interchange on new research methodologies and applications.

The new knowledge gained by this intemational group of young professionals in water reso urces will help form an up to date scientific and managerial approach to their work and undoubtedly bring multiplying effects to deal with future water resource 
problems intemationally and to a chieve considerable improvements in access and sa nita tion as oriented in the Susta ina bility Development Goal 6 in their countries.

This public ation is the expression of this a c tive interchange between partic ipants of the Course and includes research papers from students and scientists.

Prof. Katherine Vammen

Cha irwoman-Water Comittee InterAmeric an Network of Academy of Science (IANAS) 


\section{Preface}

From 1st to 15th of September 2017, 100 MsC and Ph.D students from 21 countries, partic ipated in São Carlos, Sã o Paulo State, Brazil of an Advanced Course in Integrated Water Reso urces Development sponsored fully by the São Paulo Research Foundation (FAPESP). The a im of this course was to promote a complete overview and systemic approach to the management of water resources a critic al trouble of the 21st Century. Eleven specia lists from Brazil, Colombia, Poland, Venezuela and the Director of The UNESC O Internationa I Hyd rologic a I Program, partic ipated as lectures of this process in Limnology and Aquatic Ecosystems to the Management of Water Resources. Scientific and Technological approaches were developed.

The Course consisted of lectures, disc ussions, field work, and a poster exhibition in the Final Day.

This book is a contrib ution of the students and researc $h$ workers that partic ipated in the event, and it is one of the products of the training activity.

We a re extremely indebted to SABESP that provided photos, and registered all lectures and field work.

Other sponsors were Imobiliá ria Cardinalli, Latina, Airship Brazil, Distribuidora Modenutti, all from São Carlos.

Hotel Nacional Inn was an extremely important support for the course since provided adequate facilities, very good accommodation and recreation sites.

This tra ining a c tivity was und oubted ly only possible with the full sup port of FAPESP (Fundação de Amparo à Pesquisa do Estado de São Paulo) to which Dr. Takako Matsumura-Tundisi the course coordinator is extremely indebted. (FAPESP - Process № 2016/18658-0.

This was a lso a joint a c tivity of IANAS (Inter-Americ an Network of Ac a demies of Science) and Brazilian Academy of Sciences (BAS).

Dr. Takako Matsumura Tundisi

Dr. J osé Galizia Tundisi

Editors 
14 


\title{
Diatoms as Indicators of Anthropogenic Changes in Water Quality in Mucheke and Shagashe Rivers, Masvingo, Zimbabwe
}

\author{
Bere, T. ${ }^{1, *}$; Chakandina kira, A.T. ${ }^{1}$
}

${ }^{1}$ Department of Freshwater and Fishery Science, Chinhoyi University of Technology, Off Ha ra re-Chirundu Rd, P. Bag 7724, Chinhoyi, Zmbabwe

*Corresponding a uthor: taubere@yahoo.com/tbere@cut.ac.zw

\section{Abstract}

The most widely used method of water quality assessment, physic al and chemic al variables a ssessment is less reliable compared to the use of biologic al methods such as diatom assemblages. The objec tive of this study was to (1) assess response of diatom assemblages to anthropogenic changes in water qua lity in two rivers that $\mathrm{dra}$ in a $\mathrm{n}$ urban area in Masvingo, Zmbabwe, (2) test the applic ability of the Trophic diatom index (TDI) and Pampean diatom index (PDI) in assessing water quality in the study area. Water quality sampling and benthic diatom community data were collected in May to J uly 2012 from nine sampling stations in the Mucheke and Shaga she Rivers, Zmbabwe.The data were subjected to canonic al correspondence a nalysis (CCA) to determine environmental gradients a long which the diatom species were distributed. Diatom-based biotic indicesi.e. the TDI and PDI were used to determine the ecological sta tus of study streams in relation to human-induced stressors. Pearson's correlation was used to determine the relationship between the calculated index scores and measured physic al and chemic al water quality data. Two-way ANOVA was used to compare these correlation values among sampling stations. The PDI and TDI scores on all the sampling sites showed signific ant correlations with physic al and chemic al 
variables. Thus, the indic es proved useful in providing an indic ation of the qua lity of the investigated waters. No signific ant differences in physic al and chemic al va ria bles were recorded between the three sampling periods. Diatom community structure closely reflected this gradient, with communities from polluted sampling stations (U1, U2, U3, U4 and U5) being different from other communities. Polluted sampling stations were associated with pollution tolerant species such as Diatoma vulgaris, Nitzsc hia palea, Fragilaria biceps, Achnanthes exigua and Cymatopleura solea. Dia toms communities demonstrated potential for acting as indic ators of changes in water quality due to organic and industrial pollution and are therefore recommended for use in research and monitoring of water bodies by relevant governmental and non-governmental organizations in Zmbabwe.

Keywords: dia toms, biological monitoring, pollution, water quality, dia tom indices.

\section{Introduction}

The success of huma n civilization is la rgely due to our skills as ecosystem eng ineers (KIM; WEA VER, 1994). Although these engineering a ctivities a re prima rily directed towardsachieving some specific purposes (e.g. industrial production), most have major indirect and unintended effects on ecosystems (TANNER, 2001). Freshwater ecosystems a re among the most endangered ecosystems in the world and the decline in freshwater biodiversity is far greater than in most affected te rrestrial ec osystems (DUDGEON et al., 2006). Disposal of huma $n$ waste has now become one of the greatest challenges of urbanization in both developed and developing countries (BERE, 2007; BEYENE et al., 2010). This problem is more severe in developing countries like Zmbabwe where rapid urbanization, coupled with rapid population growth, is not matched by associa ted technic al sta ndards for systems such as sewage treatment, collection of garbage and urban drainage due to economic problems and socio-political bewild erments (DUBE; SWATUK, 2002; BERE; MANGAD正, 2014; MANG AD正 et al., 2016; MWEDZ et al., 2016). In such instances, waterways are used for disposal of sewage and industrial effluent leading to problems such as the eutrophication and organic pollution (HARPER, 1992; BERE, 2007).

Two threads of basic approaches to the assessment of water quality deterio ration in streams run through the literature; physic al and chemical methods and biological methods (BERE; TUNDISI, 2010). Physic al and chemical methods provide, at best, a fragmented overview of the state of aquatic systems, as sporadic or periodic sampling cannot reflect fluxes of efflue nt disc ha rge (TAYLOR et al., 2007b). The chemistry at any given time is a snapshot of the water qua lity at the time of sampling ignoring temporal variation of wa ter quality va riables that is usua lly high in streams (TAYLOR et al., 2007b). In 
contrast, biological monitoring (the theory behind which decoding environmental change information enshrined in biota) gives a time-integrated indic ation of the water qua lity components because of the capa city of reflecting cond itions that a re not present at the time of sample collection and a na lysis (KARR, 1981; TAYLOR et al., 2007b). Biological monitoring is a fast and cost effective approach for assessing the effects of environmental stressors, making it a particularly essentia I tool for the management of rivers in developing countries (ROUND, 1991).

Benthic diatoms are amongst the commonly used biological indic ators because they offer several advantages compared to other potential biological indic a tors like fish, macro invertebrates and plants (HARDING et al., 2005; BERE, TUNDISI, 2010; SMOL; STOERMER, 2010). Dia toms, a type of uni-c ellular algae, have a short developmental cycle (a few hours to several days), depending on species and environmental conditions, a rich species composition and wide distribution thus making them ideal for bio-monitoring (RIMET, BOUC HEZ, 2011). Changes in water chemistry will inhib it the multip lic a tion of some species, while supporting that of others (tolerant species), thus the percentage composition of certa in species within a community will be changed (WERNER, 1977). Dia to ms a re sensitive to changes in nutrient concentrations i.e. growth response is directly affected by changes in prevailing nutrient concentrations and light a va ila bility (ROUND, 1991; SMO L, STO ERMER, 2010; WOOD et al., 2016).
Each taxon has a specific optimum and tolerance for nutrients such as phosphate and nitrogen, and this is usua lly qua ntifiable. While diatoms collectively show a broad range of tolerance along a gradient of changes in water quality, ind ividual species have specific water chemistry requirements (SMOL, STO ERMER, 2010; HARDING, TAYLOR, 2011). Up to $70 \%$ of what happens to water quality can be reflected in diatom assemblages (TAYLOR et al., 2007a). Although over the last few decadesa number of biological monitoring methods have been developed for the a ssessment of water quality in streams, these have ra rely been applied in Africa, especially in Zmbab we (PHIRI et a I., 2007; BERE; MANGAD正, 2014; MANG AD正 et al., 2015, 2016). For instance, dia tom-based water qua lity a ssessment protocols have been developed and used extensively elsewhere but with little use in Zmbabwe.

Isolated cases where attempts have been made to assess water quality using diatoms rely hea vily on information from other countries. However, there is evidence that this information is less suc cessful when a pplied in other a reas (PIPP, 2002). This is due not only to the floristic differences and occurrence of endemics a mong regions, but also to the environmental differences that modify species responses to wa ter-qua lity c ha rac teristic S (POTAPOVA, CHARLES, 2002; TAYLO R et al., 2007b). The first objective of the present study was to a ssess response of diatom assemblages to anthropogenic changes in water quality in two rivers that dra in a $\mathrm{n}$ urban a rea in south-eastem Zmbabwe. The second 
objective was to test the applicability of PDI and TDI in assessing water quality in the study area. In particular, we asked: (1) to what extent observed changes in water quality reflect themselves in diatom communities in the study streams and (2) to what extend PDI and TDI metrics detect changes in water quality in the study streams. We hypothesised that diatom communities are capable of reflecting changes in water quality, with PDI and TDI metric s being sensitive to water quality changes in the study region because of occurrence of ubiquitous taxa that probably have similar environmental tolerances to those recorded for these two indices.

\section{Materials and Methods}

\section{Study area}

The area under study is loc ated in the so uthern parts of Zmbabwe (Figure 1 ) in the Runde catc hment a rea. The two study rivers, Mucheke and Shagashe, fall in a subtropical steppe/low-latitude semi-arid climatic region were the average temperature and ra infall pattems a re $19.4^{\circ} \mathrm{C}$ and $623 \mathrm{~mm}$ per annum. Headwaters of the study rivers fall ma inly within a $n$ agric ultural a rea where crop production and a nimal husbandry is practiced. From the agricultural a rea, the streams pass through urban area of the city of Masvingo, a medium-sized city with a population of 88554 (Zmbabwe National Sta tistic s Agency - ZNSA) loc a ted at the confluence of these rivers. Due to rapid population growth, that is not matched by upgrading of systems such as sewage treatment, collection of garbage and urban drainage due to economic problems and socio-political bewilderments, the capacity of municipal sewage treatment facilities has been exceeded. Poor maintenance and breakdowns of these facilities is a lso very common because of the financial constrains currently facing the munic ipality. Options that a re a vailable for sewage treatment such as biological nutrient removal plants, conventiona I stabilization ponds, septic tanks and blair la trines a re not being exploited to combat eutrophication because of the nation's economic and social problems (MAPIRA, 2011). Therefore, the study strea ms receive untreated or semi-treated effluent from sewage treatment plants and bust sewage pipes as well as other diffuse sources as they pass thorough the city.

Nine sampling sites were established along the two rivers: two sites ( $R 1$ and R2) in the relatively less impacted agric ultural and forested headwaters to act as reference sites; five sites (U1, U2, U3, U4 and U5) in the polluted urban area; and two sites (D1 and D2) in downstream area after the urban area where water quality is expected to improve due to river self-purific a tion c a pa city (BERE, 2007). The rational for choosing the sampling sites was to obta in a pollution gradient of all the stream systems from rela tively unpolluted a gric ultura I head wa ters to highly polluted urban downstream sites. Monthly samplings of diatom and water quality were conducted from may to july 


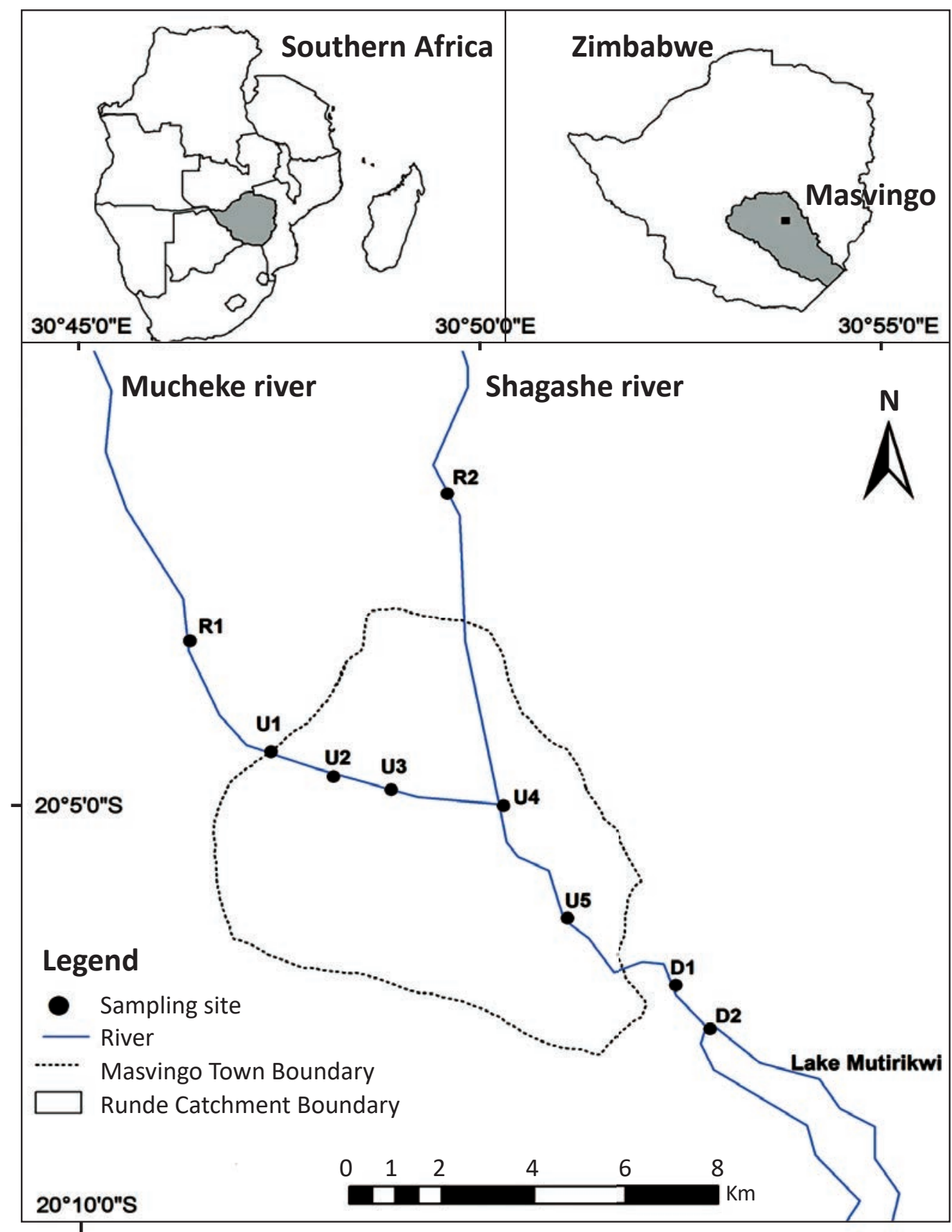

Figure 1 - The location of the Mucheke and Shagashe rivers showing the location of the sampling stations (R1 and R2 = reference sites; U1-U5 = urban sites; D1 and D2 = downstream sites).

2012. The dry season was chosen to avoid variable effects of the ra iny season such as great variations in water level and velocity, floods and inundations. These variations affect the growth, development of diatoms and the relative abundance of different species (ROUND, 1991).
Water quality sampling and analys is

At each site, dissolved oxygen (DO), electric al conductivity, specific conductivity, nitrate $\left(\mathrm{NO}_{3}\right)$, a mmonium, 
a mmonia, chloride, total dissolved solids (TDS), salinity and $\mathrm{pH}$ were measured using a portable meter (YSI professional plus, Yellowstone. USA).

\section{Epilithic diatom sampling}

At each site, epilithic diatoms were sampled by brushing stones with a tooth brush following (HARDING et al., 2005). Prior to sampling of epilithic surfaces, all substrata were gently shaken in the stream water to remove any loosely attached sediments and non-epilithic diatoms. At least five pebble-to-cobble $(5-15 \mathrm{~cm})$, sized stones were randomly collected along each sampling stretch, brushed and the resulting diatom suspensions were pooled to form a single sample which was then put in a labeled plastic container. The dislodged material was decanted into a sample bottle and preserved using formalin to be identified in the laboratory.

In the laboratory, sub-samples of the diatom suspensions were cleaned of organic material using wet combustion with concentrated sulphuric acid and hydrogen peroxide and mounted in Naphrax (Northem Biological supplies Ltd., UK, R1 $=1.74$ ) following Biggs and Kilroy (2000). Three replic ate slides were prepared for each sample. A total of 300-650 valves persample (based on counting efficiency determination method by Pappas and Stoermer (1996) were identified and counted using a compound microscope (× 1000; Nilc on, Alpha phot 2, Type YS2-H,
China). The diatoms were identified to species level based mainly on studies from South Africa (TAYLOR et al., 2007a); stud ies from other tropic al regions were consulted when necessary e.g. (MET\&LTIN, LANG E-BERTALOT, 1998).

\section{Indices calculation}

The PDI and TDI were calculated following Gómez and Lic ursi (2001) and Kelly et al. (2001) respectively. The PDI values range from 0 to 4 as follows: 0-0.5 (very good), > 0.5-1.5 (good), > 1.5-2 (acceptable); $>2-3=$ bad and $>$ 3-4 (very bad) water quality.Values for the TDI range from 1 (very low nutrient concentrations) to 5 (very high nutrient concentrations). The percentage pollution tolerance taxa is then calculated as a measure of the reliability of the trophic dia tom index. Different categories a re drawn out from the percentage values to come up with an interpretation of the proportion of count composed of taxa tolerant to organic pollution.

\section{Statistical analysis}

A two-way a nalysis of va ria nce (Two-Way ANOVA) with Tukey's post hoc HSD tests was used to compare means of physical and chemic al va riables a mong the three sampling station categories and between the three sampling periods. Pearson's correlation was used to determine the relationship between the calculated 
index scores (TDI and PDI) and measured physical and chemical water qua lity data. One-way ANOVA was used to compare the PDI and TDI scores among sampling sta tions.

Multivariate data a nalyses were performed on the diatom community data to explore the main gradients of floristic va riation and to detect and visualize simila rities in dia to $m$ sa mples. Prelimina ry detrended correspondence a nalysis (DCA) was applied on diatom data set to determine the length of the gradient. The DCA revealed that the gradient was greater than three standard deviation units, justifying the use of unimodial ordination tec hniques (ter Bra ak and Verdonschot, 1995). Thus, canonical correspondence analysis (CCA) was performed to relate dia tom community structure to simulta neous effects of predic tor environmental va riables, and to explore the relationship amongst and between species and predictor variables. Preliminary C CA identified collinearvariables and selected a subset on inspection of variance inflation factors (VIF $<20$ ); (Ter Bra ak and Smila uer, 2002). Monte Carlo permutation tests (999 unrestric ted permutations, $p \leq 0.05$ ) were used to test the significance of the axis and determine if the selected environmental variables could expla in nearly a s much variation in the diatom community structure as all the environmental va ria bles combined. DCA and CCAs were performed using CANOCO version 4.5 (TER BRAAK; SMILAUER, 2002). All other statistic al tests were performed with Pala eontological Sta tistics So ftwa re (PAST) Version 2.16 (Ha mmer et al., 2001).

\section{Physical and chemical variables}

The values of the physioc hemical variables recorded in the Mucheke and Shagashe River during this study a re summarized in Table 1 . A tota I of 10 environmental va ria bles were a na lyzed. Generally, water quality deteriorated at sites that were at or near disc harge points a long the two rivers (Table 1 ). Conductivity and TDS were signific a ntly high in U2, U5 and D1 compared to.R1, R2 and D2 (ANOVA, $P<0.05$ ). There were no signific ant differences in $\mathrm{pH}$ and salinity among sampling stations (ANOVA, P > 0.05). Ammonia, ammonium, $\mathrm{NO}_{3}$ specific conductance and $\mathrm{Cl}$ were signific antly high in urba $n$ sampling stations (U1-U5) (ANOVA, $\mathrm{P}<0.05)$, while DO was signific antly low in the same (ANOVA, $P>0.05$ ) compared to the reference and downstream sites.

\section{Diatom indices}

The PDI and TDI scores based on all the site categories showed signific ant correlations $(P<0.05)$ with physical and chemica I variables (Table 2). Significant differences (ANOVA, $P<0.05$ ) in the PDI sc ores based on different site categories were recorded, with reference sites R1 and R2 classified as good. Downstream sites D1 and D2 were generally classified as acceptable and good respectively, while urban sites U1, U2, U3, U4 and U5 were classified as bad.

Simila rly, signific a nt differences (ANOVA, P < 0.05) in the TDI scores 


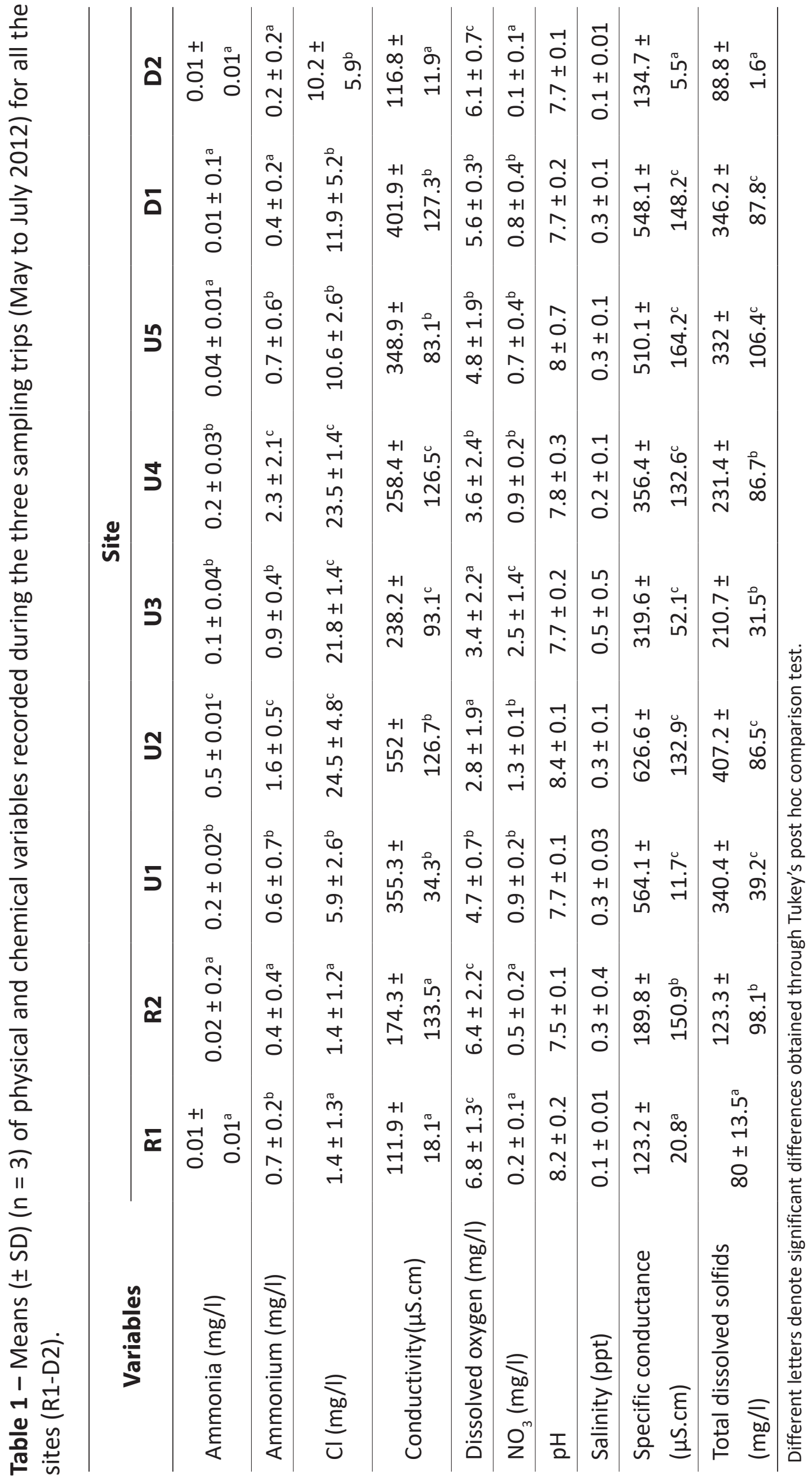


based on different site categories were recorded (Figure 3). Reference sites (R1 and R2) as well as downstream sites (D1 and D2) had low percentage pollution tolerant taxa (below $20 \%$ ), which means they were free from significant organic pollution (Figure 3). Urban sites generally had high percentage pollution tolerant taxa (a bove $20 \%$; Figure 3) ind ic a ting some evidence of organic pollution and in some cases (sites U3, U4 and U5) organic pollution was likely to be contributing signific a ntly to eutro phic ation. Correlations between the PDI scores and physic al and chemic al variables were a lso generally lower compared to those between the TDI scores and physical and chemical variables.

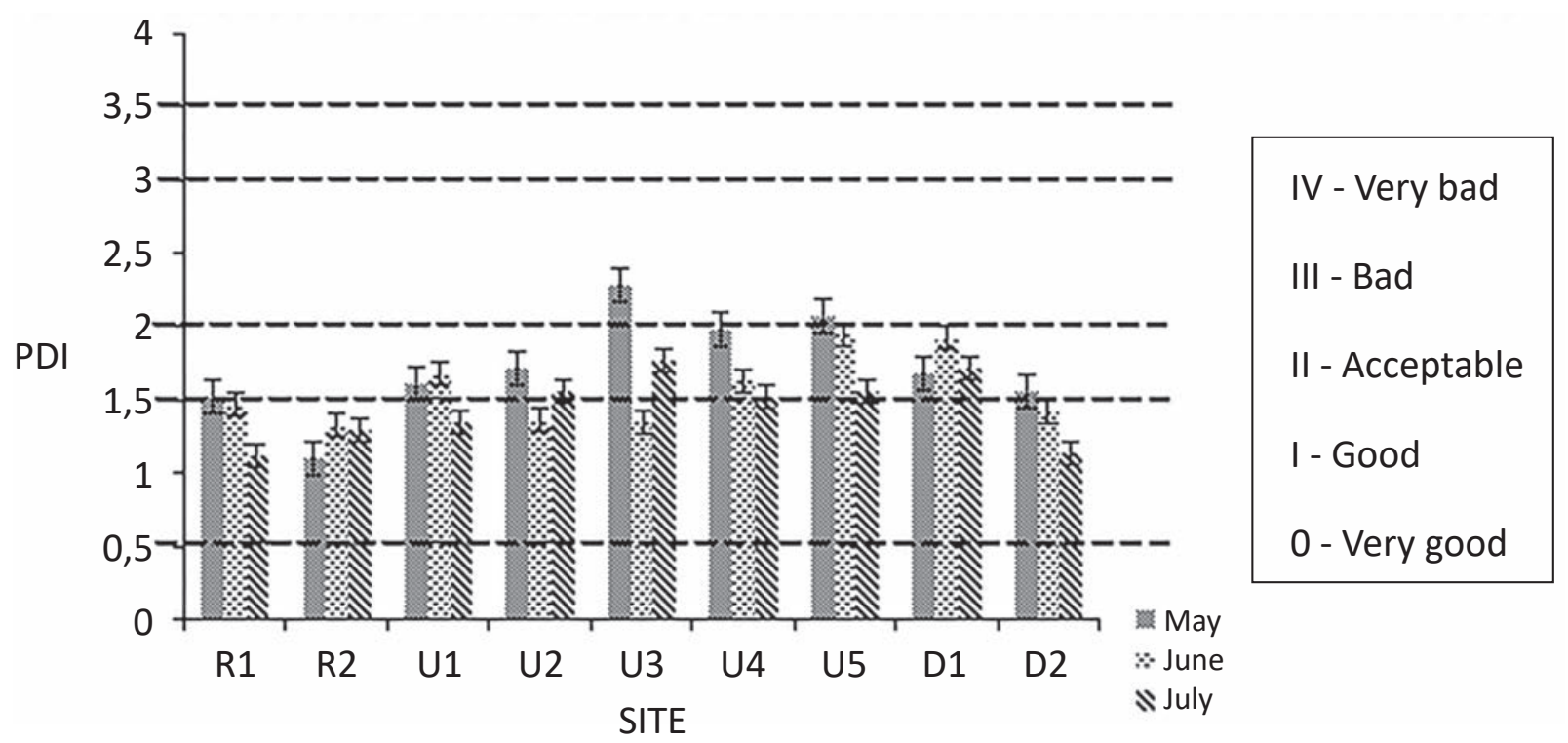

Figure 2 - The Pampean diatom index (PDI) scores recorded at sites along the Mucheke and Shagashe rivers for the study period (may to june).

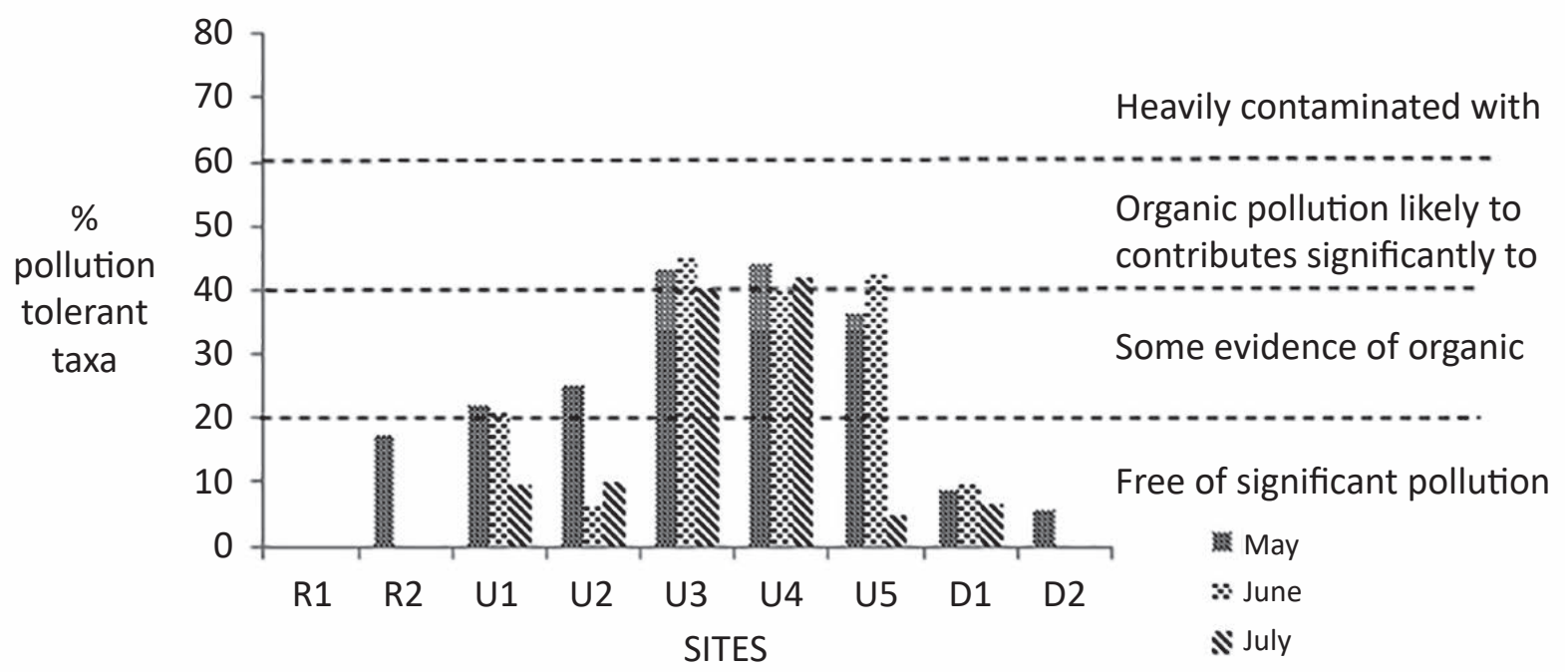

Figure 3 - Percentage pollution tolerant taxa from the nine sampling sites. 
Table 2 - Pearson's correlation between diatom indices and environmental variables.

\begin{tabular}{lcc}
\hline \multirow{2}{*}{ Parameter } & \multicolumn{2}{c}{ Metric } \\
\cline { 2 - 3 } & TDI & PDI \\
\hline Ammonia $(\mathrm{mg} / \mathrm{l})$ & 0.34 & -0.16 \\
\hline Ammonium $(\mathrm{mg} / \mathrm{I})$ & 0.48 & 0.2 \\
\hline $\mathrm{Cl}(\mathrm{mg} / \mathrm{l})$ & 0.16 & 0.07 \\
\hline Conductivity $(\mu \mathrm{S} . \mathrm{cm})$ & 0.31 & 0.29 \\
\hline Dissolved oxygen $(\mathrm{mg} / \mathrm{l})$ & -0.18 & -0.03 \\
\hline NO3 (mg/l) & -0.09 & -0.2 \\
\hline pH & -0.2 & 0.07 \\
\hline Salinity (ppt) & 0.48 & -0.1 \\
\hline Total dissolved solids $(\mathrm{mg} / \mathrm{l})$ & 0.41 & 0.38 \\
\hline
\end{tabular}

\section{Community composition}

A total of 39 diatom species belonging to 25 genera were identified in all nine sampling sites (Table 3). Species composition in terms of species ric hness, species diversity, dominance and evenness is in the same range for reference and downstream sites compared to urban sites.

The results of CCA are presented in Figure 4. The first fouraxes of the selected explora tory variables a c counted for $79.9 \%$ of the total variance in the community data (Table 2). Axis 1 and 2 signific antly explained $26.4 \%$ and $16.3 \%$, respectively, of the diatom species va ria nce (Table 2; Monte $\mathrm{C}$ arlo unrestricted permutation, $\mathrm{P}$ $<0.05)$. CCA Axes 1 and 2 separated the sites into 3 groups. The first group consisted of less polluted sites R1 and R2 that were positively a ssociated with the first axis. Dia to $m$ species characterising these sites include species such as Achnanthidium minutissimum, Aulacoseira distans, Enc yonema silesiacum, Enc yonopsis minuta, Cymatopleura solea, Eunotia flexuosa Diploneis subovalis, Cymbella kappii, Eunotia flexuosa, Fragilaria nanana, Rhopa lodia gibba, Dia desmis confervacea, Bra chysira neoexilis, Gomphonema la tic ollum,C yma to pleura solea, Pinnula ria acrosphaeria, Gomphonema minitum, Pinnularia subcapita ta and Sta urosirella pinnata. The second group consisted of highly polluted sites (U1-U5) that were negatively associated with the first and positively associated with the second axis, respectively (Figure 4). These sites were associated with high ammonium, ammonia and nitrate levels. Diatom species characterising these sites include species such as Frag ila ria bic eps, Fragila ria ulna, Rhoicosphenia abbreviate, Cyclotella meneghiniana, Nitzsc hia palea, Gomphonema parvulum, Cyclotella sp $p$, Pinnularia confirma, Pinnula ria virid iformis. This group of species was associated with high levels of a mmonia, a mmonium and nitra te as compared to the rest of the species. The third group consisted of medium polluted sites D1 and D2 that were negatively associated with the first and second axis. These sites were associated with high salinity and $\mathrm{pH}$ levels. Nutrient levels were generally low compared to those of sites U1-U5. Sites D1and D2 wereassociated Pleurosigma 
elongatum, Ta bellaria flocculosa, frustulum, Gomphonema insigne, Fallacia Sellaphora stroemii, Sellaphora seminulum, monoculata, Achna nthes exigua and Pla nothidium frequentissimum, Nitzschia Diatoma vulgaris.

Table 3 - Mean values of species richness, diversity, dominance and evenness.

\begin{tabular}{lccccccccc}
\hline & S1 & R2 & U1 & U2 & U3 & U4 & U5 & D1 & D2 \\
\hline Speciesrichness & $8 \pm 1$ & $10 \pm 2$ & $8 \pm 1$ & $10 \pm 0$ & $7 \pm 1$ & $5 \pm 1$ & $6 \pm 2$ & $10 \pm 2$ & $9 \pm 2$ \\
\hline \multirow{2}{*}{ Shannondiversity } & $1.6 \pm$ & $2.1 \pm$ & $1.9 \pm$ & $2.1 \pm$ & $1.8 \pm$ & $1.5 \pm$ & $1.5 \pm$ & $1.8 \pm$ & $1.8 \pm$ \\
& 1.8 & 0.1 & 0.3 & 0.04 & 0.2 & 0.1 & 0.4 & 0.3 & 0.2 \\
\hline \multirow{2}{*}{ Dominance } & $0.3 \pm$ & $0.1 \pm$ & $0.2 \pm$ & $0.1 \pm$ & $0.2 \pm$ & $0.2 \pm$ & $0.3 \pm$ & $0.3 \pm$ & $0.2 \pm$ \\
& 0.1 & 0.02 & 0.1 & 0.01 & 0.03 & 0.03 & 0.1 & 0.1 & 0.04 \\
\hline \multirow{2}{*}{ Evenness } & $0.6 \pm$ & $0.8 \pm$ & $0.8 \pm$ & $0.8 \pm$ & $0.9 \pm$ & $0.8 \pm$ & $0.7 \pm$ & $0.6 \pm$ & $0.7 \pm$ \\
& 0.1 & 0.05 & 0.1 & 0.03 & 0.05 & 0.05 & 0.1 & 0.2 & 0.02 \\
\hline
\end{tabular}

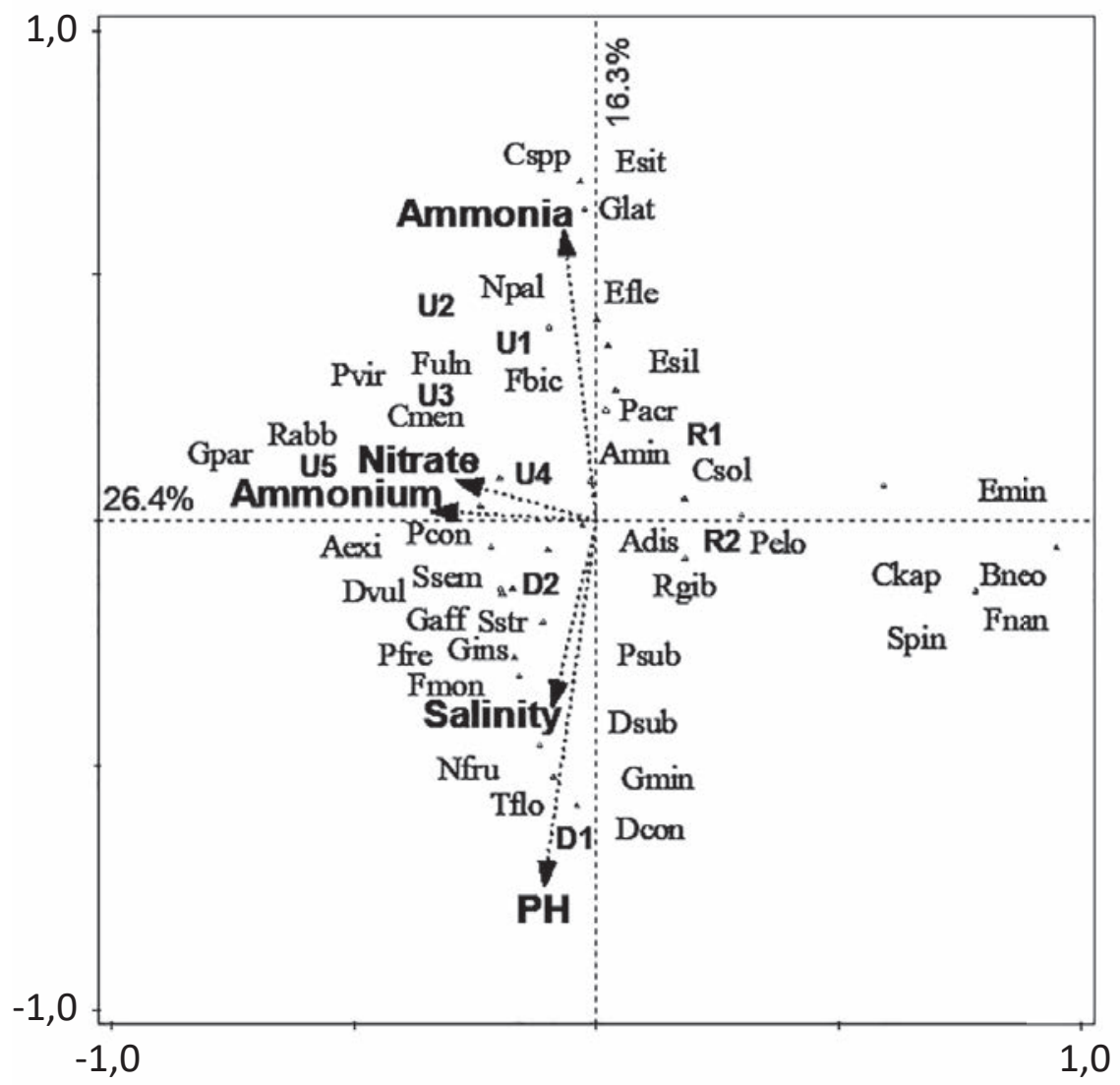

Figure 7-Ordination diagram based on canonical correspondence analysis (CCA) of diatom species composition in nine sampling sites in respect with six environmental variables. 
Table 4 - Diatom species codes used in the canonical correspondence analysis.

\begin{tabular}{lc}
\hline \multicolumn{1}{c}{ Species } & Code \\
\hline Achnanthes exigua & Aexi \\
\hline Achnanthidium minutissimum & Amin \\
\hline Aulacoseira distans & Adis \\
\hline Brachysira neoexilis & Bneo \\
\hline Cyclotella meneghiniana & Cmen \\
\hline Cyclotella species & Cspp \\
\hline Cymatopleura solea & Csol \\
\hline Cymbella kappii & Ckap \\
\hline Diadesmis confervacea & Dcon \\
\hline Diatoma vulgaris & Dvul \\
\hline Diploneis subovalis & Dsub \\
\hline Encyonopsis minuta & Emin \\
\hline Encyonema silesiacum & Esil \\
\hline Encyonema sitesiam & Esit \\
\hline Eunotia flexuosa & Efle \\
\hline Fallacia monoculata & Fmon \\
\hline Fragilaria biceps & Fbic \\
\hline Fragilaria nanana & Fnan \\
\hline Fragilaria ulna & Fuln \\
\hline Gomphonema affine & Gaff \\
\hline
\end{tabular}

\begin{tabular}{lc}
\hline \multicolumn{1}{c}{ Species } & Code \\
\hline Gomphonema insigne & Gins \\
\hline Gomphonema laticollum & Glat \\
\hline Gomphonema minutum & Gmin \\
\hline Gomphonema parvulum & Gpar \\
\hline Nitzschia frustulum & Nfru \\
\hline Nitzschia palea & Npal \\
\hline Nitzschia reversa & Nrev \\
\hline Pinnularia acrosphaeria & Pacr \\
\hline Pinnularia confirma & Pcon \\
\hline Pinnularia subcapitata & Psub \\
\hline Pinnularia viridiformis & Pvir \\
\hline Planothidium frequentissimum & Pfre \\
\hline Pleurosigma elongatum & Pelo \\
\hline Rhoicosphenia abbreviata & Rabb \\
\hline Rhopalodia gibba & Rgib \\
\hline Sellaphora seminulum & Ssem \\
\hline Sellaphora stroemii & Sstr \\
\hline Staurosirella pinnata & Spin \\
\hline Tabellaria flocculosa & Tflo \\
\hline
\end{tabular}

\section{Discussion}

\section{Water quality}

The results of the physic al and chemical variables in the study showed that pollution levels, especially orga nic pollution and eutrophic ation, differed among the sites sampled (Table 1). Conductivity, a mmonium, ammonia, chloride and nitrate were signific a ntly higher in sites that were

near or at a pollution point in the urban a reas. Industrial, domestic and sewage effluent disposals a re the ma in causes of decrease in the water quality along the Mucheke and Shaga she River system. These high levels of nutrients a re assoc ia ted with deterioration of water quality and eventually lead to eutrophic ation and changes in diatom species composition (BERE, 2010). 
Diatom community structure in relation

to environmenta 7 variables

Dia to m community struc ture and composition closely followed the observed changes in pollution levels, with less polluted sites R1 and R2 being associated with diatom communities that were different from highly polluted sites U1, U2, U3, U4 and U5. C luster analysis of sampling stations based on epilithic diatom communities in streams of the Mucheke and Shagashe river clearly reflected the effects of pollution (Figure 2). The epilithic algal communities in this study were prima rily affected by organic pollution and nutrient concentrations in the streams resulting from urban runoff as confirmed by the findings of Beyene et al. (2010). Diatoms have an important role in biological monitoring of lotic systems as they have shown capacity to respond to changes in water quality. Ammonia, Ammonium, salinity, $\mathrm{pH}$ and nitra te were found to be important in structuring benthic diatom communities in the study a rea (Figure 4). Other studies have also shown that nutrients (ammonia, ammonium and nitrate)are the primary drivers of periphyton community struc ture and biomass (BIGGS, THOMSEN, 1995; J OWEIT, BIGGS, 1997). Nonetheless, a review of litera ture ca rried out by (SAROS, FRITZ, 2000) showed that sa linity may influence nutrient availability to primary producers, as well as nutrient requirements and uptake by diatoms. pH exerts a direct physiologic al stress on dia toms (G ENSEMER, 1991), and also strongly influences other water chemistry va riables (SIG G, STUMM, 1981). Based on the CCA (Figure 4), sites that were relatively more polluted had pollution tolerant species such as Nitzsc hia palea, Gomphonema parvulum, Cyclotella spp, Pinnularia confirma and Pinnularia virid iformis. These species are known to be resistant to heavy metal and organic pollution (ROUND, 1991; BERE, TUNDISI, 2010). Whereas, reference sites R1 and $\mathrm{R} 2$ were characterized by low pollution tolerant speciessuch as Fra gila ria nanana, Rhopalodia gibba, Diadesmis confervacea, Bra chysira neoexilis, Gomphonema la tic ollum,Cymatopleura solea,Pinnula ria acrosphaeria, Gomphonema minitum, Pinnularia subcapitata and Sta urosirella pinnata. These species a re mainly found in oligo - to mesotrophic water with moderate cond uc tivity (VAN DAM et al., 1994; BERE, TUNDISI, 2011).

\section{Applicabi7ity of TDI and PDI to the study area}

The signific a nt correlations between TDI and PDI index values and physical and chemical chara c teristic s of streams recorded in this study indic ate that these indices may be used to reflect general changes in water quality of rivers and streams of Zmbabwe (Table 2). Values of the TDI and PDI indices showed signific ant differences between reference sites $R 1$ and R2 and heavily polluted urban sites U1-U5 (Figures 2 and 3). This is supported by (Bate et al., 2004) who found that most dominant dia tom species found in South Afric a n rivers were already recorded in 
intemational studies. Thus, most foreign diatom indices may be used in the study a rea as they are based on the ecology of widely distributed or cosmopolitan taxa. In conclusion, it can be said that the PDI and TDI a re applicable to the study area. Diatoms have an important role in biological monitoring of lotic systems as they have shown capacity to respond to changes in water quality.

\section{Conclusion}

In conclusion, orga nic and ind ustria I effluent has a great effect on the water

\section{References}

BATE, G., SMAILES, P. and ADAMS, J., 2004. A water quality index for use with diatoms in the assessment of rivers. Water SA, vol. 30, no. 4, pp. 493-498.

BERE, T., 2007. The assessment of nutrient loading and retention in the upper segment of the Chinyika River, Harare: Implications for eutrophication control. Water SA, vol. 33, no. 2.

BERE, T., 2010. Benthic diatom community structure and habitat preferences along an urban pollution gradient in the Monjolinho River, São Carlos, SP, Brazil. Acta Limnologica Brasiliensia, vol. 22, no. 1, pp. 80-92.

BERE, T. and MANGADZE, T., 2014. Diatom communities in streams draining urban areas: community structure in relation to environmental variables. Tropical Ecology, vol. 55, no. 2, pp. 271-281.

BERE, T. and TUNDISI, J., 2010. Biological monitoring of lotic ecosystems: the role of diatoms. Brazilian Journal of Biology, vol. 70, no. 3, pp. 493-502.

BERE, T. and TUNDISI, J., 2011. Influence of ionic strength and conductivity on benthic diatom communities in a tropical river (Monjolinho), São Carlos-SP, Brazil. Hydrobiologia, vol. 661, no. 1, pp. 261-276. qua lity of Mucheke and Shagashe Rivers as shown by the physical and chemical variables of the two rivers. Changes in the a ssemblages of diatom species a re also evident of changes in wa ter qua lity a long the rivers, thus a relationship between diatoms and water quality. Diatoms have an important role in biological monitoring of lotic systems as they has shown capacity to respond to changes in water quality. Biologic a I monitoring of wa ter qua lity using diatoms is a reliable method for water quality assessment and should therefore be adapted in research and by relevant govemment organizations.

BEYENE, T., LETTENMAIER, D.P. and KABAT, P., 2010. Hydrologic impacts of climate change on the Nile River Basin: implications of the 2007 IPCC scenarios. Climatic change, no. 100, vol. 3-4, pp. 433-461.

BIGGS, B. and KILROY, C., 2000. Stream periphyton monitoring manual: Niwa.

BIGGS, B.J. and THOMSEN, H.A., 1995. Disturbance of stream periphyton by perturbations in shear stress: time to structural failure and differences in community resistance. Journal of Phycology, vol. 1 , no. 2, pp. 233-241.

DUBE, D. and SWATUK, L.A., 2002. Stakeholder participation in the new water management approach: a case study of the Save catchment, Zimbabwe. Physics and Chemistry of the Earth, Parts $A / B / C$, vol. 27, no. 11, pp. 867-874.

DUDGEON, D., ARTHINGTON, A.H., GESSNER, M.O., KAWABATA, Z.-I., KNOWLER, D.J., LÉVÊQUE, C., NAIMAN, R.J., PRIEUR-RICHARD, A.-H., SOTO, D. and STIASSNY, M.L., 2006. Freshwater biodiversity: importance, threats, status and conservation challenges. Biological reviews, vol. 81, no. 2, pp. 163-182.

GENSEMER, R.W., 1991. The effects of $\mathrm{pH}$ and aluminum on the growth of the acidophilic diatom Asterionella ralfsii var. americana. Limnology and Oceanography, vol. 36, no. 1, pp. 123-131. 
GÓMEZ, N. and LICURSI, M., 2001. The Pampean Diatom Index (IDP) for assessment of rivers and streams in Argentina. Aquatic Ecology, vol. 35, no. 2, pp. 173-181.

HAMMER, O., HARPER, D. and RYAN, P., 2001. PAST (Paleontological Statistics) version 3.14. Software package for education and data analysis. Paleontología Electrónica, vol. 4, no. 1, p. 9.

HARDING, W., ARCHIBALD, C. and TAYLOR, J., 2005. The relevance of diatoms for water quality assessment in South Africa: A position paper. Water SA, vol. 31, no. 1, pp. 41-46.

HARDING, W. and TAYLOR, J., 2011. The South African Diatom Index (SADI): A Preliminary Index for Indicating Water Quality in Rivers and Streams in Southern Africa. Report to the Water Research Commission, Water Research Commission.

HARPER, D.M., 1992. Eutrophication of freshwaters: Springer.

JOWETT, I.G. and BIGGS, B.J., 1997. Flood and velocity effects on periphyton and silt accumulation in two New Zealand rivers. New Zealand Journal of Marine and Freshwater Research, vol. 31, no. 3, pp. 287-300.

KARR, J.R., 1981. Assessment of Biotic Integrity Using Fish Communities. Fisheries, vol. 6, no. 6, pp. 21-27. http://dx.doi.org/ 10.1577/1548-8446(1981)006<0021:AOBIUF>2.0.CO,2

KELLY, M., ADAMS, C. and GRAVES, A., 2001. The Trophic Diatom Index: A User's Manual, Revised Edition, Environment Agency.

KIM, K.C. and WEAVER, R.D., 1994. Biodiversity and landscapes: a paradox of humanity: Cambridge University Press.

MANGADZE, T., BERE, T. and MWEDZI, T., 2015. Epilithic diatom flora in contrasting land-use settings in tropical streams, Manyame Catchment, Zimbabwe. Hydrobiologia, vol. 753, no. 1, pp. 163-173.

MANGADZE, T., BERE, T. and MWEDZI, T., 2016. Choice of biota in stream assessment and monitoring programs in tropical streams: A comparison of diatoms, macroinvertebrates and fish. Ecological Indicators, vol. 63, pp. 128-143.

MAPIRA, J., 2011. Sewage treatment, disposal and management problems, and the quest for a cleaner environment in Masvingo city (Zimbabwe). Journal of Sustainable Development in Africa, vol. 13, no. 4.

METZELTIN, D. and LANGE-BERTALOT, H., 1988. Tropische Diatomeen in Südamerika, I: Koeltz Scientific Books, vol. 1.
MWEDZI, T., BERE, T. and MANGADZE, T., 2016. Macroinvertebrate assemblages in agricultural, mining, and urban tropical streams: implications for conservation and management. Environmental Science and Pollution Research, vol. 1-12.

PAPPAS, J.L. and STOERMER, E.F., 1996. Quantitative method for determining a representative algalsample count 1. Journal of Phycology, vol. 32, no. 4, pp. 693696.

PHIRI, C., DAY, J., CHIMBARI, M. and DHLOMO, E., 2007. Epiphytic diatoms associated with a submerged macrophyte, Vallisneria aethiopica, in the shallow marginal areas of Sanyati Basin (Lake Kariba): a preliminary assessment of their use as biomonitoring tools. Aquatic Ecology, vol. 41, no. 2, pp. 169-181.

PIPP, E., 2002. A regional diatom-based trophic state indication system for running water sites in Upper Austria and its overregional applicability. Paper presented at the Verh. Int. Ver. Theor. Angew. Limnol./Proc. Int. Assoc. Theor. Appl. Limnol./Trav. Assoc. Int. Limnol. Theor. Appl.

POTAPOVA, M.G. and CHARLES, D.F., 2002. Benthic diatoms in USA rivers: distributions along spatial and environmental gradients. Journal of biogeography, vol. 29, no. 2, pp. 167-187.

RIMET, F. and BOUCHEZ, A., 2011. Use of diatom life-forms and ecological guilds to assess pesticide contamination in rivers: lotic mesocosm approaches. Ecological Indicators, vol. 11, no. 2, pp. 489-499.

ROUND, F., 1991. Diatoms in river water-monitoring studies. Journal of Applied Phycology, vol. 3, no. 2, pp. 129-145.

SAROS, J. and FRITZ, S.C., 2000. Nutrients as a link between ionic concentration/composition and diatom distributions in saline lakes. Journal of Paleolimnology, vol. 23, no. 4, pp. 449-453.

SIGG, L. and STUMM, W., 1981. The interaction of anions and weak acids with the hydrous goethite (a-FeOOH) surface. Colloids and surfaces, vol. 2, no. 2, 101-117.

SMOL, J.P. and STOERMER, E.F., 2010. The diatoms: applications for the environmental and earth sciences. Cambridge University Press.

TAYLOR, J., VAN VUUREN, M.J. and PIETERSE, A., 2007a. The application and testing of diatom-based indices in the Vaal and Wilge Rivers, South Africa. Water SA, vol. 33, no. 1. 
TAYLOR, J.C., PRYGIEL, J., VOSLOO, A., PIETER, A. and VAN RENSBURG, L., 2007b. Can diatom-based pollution indices be used for biomonitoring in South Africa? A case study of the Crocodile West and Marico water management area. Hydrobiologia, vol. 592, no. 1, pp. 455-464.

TER BRAAK, C. and SMILAUER, P., 2002. Canoco for Windows version 4.5. Biometris-Plant Research International, Wageningen.

TER BRAAK, C.J. and VERDONSCHOT, P.F., 1995. Canonical correspondence analysis and related multivariate methods in aquatic ecology. Aquatic Sciences, vol. 57, no. 3, pp. 255-289.
VAN DAM, H., MERTENS, A. and SINKELDAM, J. A, 1994. coded checklist and ecological indicator values of freshwater diatoms from the Netherlands. Aquatic Ecology, vol. 28, no. 1, pp. 117-133, 1994. WERNER, D., 1977. The biology of diatoms. Univ of California Press, vol. 13.

WOOD, R.J., MITROVIC, S.M., LIM, R.P. and KEFFORD, B.J., 2016. The influence of reduced light intensity on the response of benthic diatoms to herbicide exposure. Environmental Toxicology and Chemistry, vol. 35, no. 9, pp. 2252-2260. http://dx.doi.org/10.1002/ etc. 3379 


\section{Analysis of Surface and Ground Water Samples in the Environs of Gold Mines Linked to Lead Poisoning Incident in Niger State, Nigeria}

Adio-Adepoju, A.A. ${ }^{1,}{ }^{*}$, Okiei, W.O. ${ }^{1}$, Ogunlesi, M. ${ }^{1}$, Ojobe, B.L.', Ibrahim, G.O.', Sobowale, O.S. ${ }^{1}$

${ }^{1}$ Chemistry Department, University of Lagos, Akoka, Lagos, Nigeria *Corresponding autor: audioderyne@gmail.com

\section{Abstract}

Nine water samples were collected from wells, boreholes and ponds around gold mining sites in Ra fi Local Govemment Area (LGA) of Niger State, Nigeria affected by artisanal gold mining activities and where the deaths of over 28 children were recorded. The water samples were analyzed to determine their concentrations of potentially toxic meta ls using linear sweep anodic stripping volta mmetry (LSASV). The Pb concentrations in the water sample was in the range $50.15 \mu \mathrm{g} / \mathrm{L}-5916 \mu \mathrm{g} / \mathrm{L}$. These values a re above the WHO permissible limit of $10 \mu \mathrm{g} / \mathrm{L}$ for Pb in potable water. The concentrations of $\mathrm{Cu}$ in the water samples were found to be within limits and was in the range $0.002 \mu \mathrm{g} / \mathrm{L}-679$ $\mu \mathrm{g} / \mathrm{L}$. Other parameters determined and their results were $\mathrm{pH}$ (6.28-8.65), total dissolved solids ( $40 \mathrm{mg} / \mathrm{L}-760 \mathrm{mg} / \mathrm{L})$, electric al conduc tivity $(81 \mu \mathrm{S} / \mathrm{cm}-1517 \mu \mathrm{S} . \mathrm{cm})$, temperature $\left(29.6^{\circ} \mathrm{C}-36.6^{\circ} \mathrm{C}\right)$, a cidity; ( $\left.3.86 \mathrm{mg} \mathrm{CaCO} / \mathrm{L}-19.28 \mathrm{mg} \mathrm{CaCO}_{3} / \mathrm{L}\right)$, a lka linity; ( $13.73 \mathrm{mg}$ $\left.\mathrm{CaCO}_{3} / \mathrm{L}-114.45 \mathrm{mg} \mathrm{CaCO}_{3} / \mathrm{L}\right)$ and hardness; $\left(0.12 \mathrm{mg} \mathrm{CaCO}_{3} / \mathrm{L}-4.30 \mathrm{mg} \mathrm{CaCO}_{3} / \mathrm{L}\right)$. The results show that $\mathrm{Pb}$ poisoning may have been responsible for the deaths of these children in parts of Rafi LGA of Niger State.

Keywords: gold mining, heavy metal pollution, lead poisoning, water, voltammetry. 


\section{Introduction}

Mining of solid minera ls has been identified as a major source of potentially toxic metals in the environment because metal ores may conta in potentially toxic meta ls (PTM) as well a s essential elements (AROGUNJ O, 2007). The main threats to human health from heavy metals a re associated with exposure to lead, copper, c admium, mercury as well as a rsenic . These metals may enter the human body through inhalation of dust, consumption of contaminated drinking water and ingestion of food plants grown in contaminated soils (MARTINEZ-FINLEY et al., 2012; J AN et al., 2015).

Artisanal mining operations a re known to be the common methods of extraction of minerals from the earth, especially in developing countries where it is a dopted in rural a reas (VEIGA, 2003; SNEHA et al., 2012). Mining activities have been reported to have adverse effects on water resources and farmlands (ADEG BOYE, 2013) and this could lead to accumulation of PTM in such water bodies.Artisa nal gold mining has long been practiced in Nigeria and a round the world. For a lmost a century, parts of Kebbi, Niger and Zamfara States in Northern Nigeria have become hubs for illegal artisa nal miners, who use crude methods to extract gold from ores by va rious processing methods (MINING AFRIC A, 2017). These a c tivities often impact negatively on the environment resulting in land degradation, pollution of soil, plants, water bodies and air. Gold mining operations are particularly dangerous as miners use mercury to form amalgams with the metal of interest followed by washing with water. Thus water bodies such as rivers, ponds and lakes used in processing the ore a re severely polluted. Water pollution around mining areas has been reported to conta in high concentra tions of PTM which bioconcentrate in a quatic organismsand eventually biomagnifies along the food chain (NIRMAL et al., 2011).

The worst $\mathrm{Pb}$ poisoning incident in modem history took place in Zamfara Sta te in 2010 and led to the deaths of over 400 child ren und er 5 years of age. Despite the efforts of development, la ws and regula tory enforcements to control the activities, $\mathrm{Pb}$ conta mination of the environment a rising from a rtisa nal mining continues to afflict large numbers of children in several parts of northem Nigeria. In 2015 several deaths were recorded in Madaka district in Rafi LG A of Niger State and this was attributed to $\mathrm{Pb}$ poisoning a rising from the a rtisanal mining and processing of gold ores. Blood $\mathrm{Pb}$ levels of children affected were 17 to 22 times higher tha $n$ the acceptable limit of $10 \mu \mathrm{g} / \mathrm{mL}$. A similar incident leading to the deaths of several children occurred in 2010 in Anka LGA of Zamfara State. The Pb and $\mathrm{Cu}$ levels of water samples collected from ponds, streams and boreholes in Dareta and Abare showed very high concentrations of $\mathrm{Pb}$ (O KIEl et al., 2016). This was the motivation for carrying out this study on water samples collected from Madaka, Rafi Local Government Area (LGA) of Niger state.

The objective of this study was to determine the concentration of toxic metals present in surface and ground water samples collected from Rafi LGA of Niger State using electrochemical method. The physic ochemical para meters such as $\mathrm{pH}$, TDS, EC, tempera ture, a cidity, a lka linity, hardness of the water samples were also determined. 


\section{Materials and Methods}

collection of

Samples and Preservation

Samples of water were collected from Maigiro and Kawo in Rafi LGA, Niger State, northem Nigeria in May, 2016. About $500 \mathrm{~mL}$ of water samples were collected in precleaned plastic bottles in duplic a te. Duplicate sample for water collected was ac id ified using $2 \mathrm{~mL}$ of concentrated nitric acid (Sigma-Aldrich), stoppered and kept in polythene bags for hea vy metal a nalysis. Water samples (not a cidified) were also filled to the brim of some plastic bottles, stopperedand kept in dark polythene bags. Both acidified and un-acidified samples were transported to the laboratory and stored in the refrigerator at $4^{\circ} \mathrm{C}$ for further a nalysis. Coordina tes of all sa mpling points were recorded using the Garmin GPS 72 Handheld global positioning system (GPS). Depths of the wells, pondsand boreholes were also measured.

\section{Digestion of Water Samp 7 es}

$50 \mathrm{~mL}$ of eachacidified water sa mple wasmeasured into a conic al flask, heated and allowed to evaporate to $25 \mathrm{~mL}$. The digested sample wasfiltered and made up to $50 \mathrm{~mL}$ with deionized water and stored in a ir tight pre-cleaned plastic bottle.
Voltammetric

Measurements for

Heavy Meta7s

A Basi-Epsilon potentiostat/ga lva nostat was used in the voltammetric determination of heavy metals in the water samples. G lassy carbon (3.0 mm diameter) was used as the working electrode, $\mathrm{Ag} / \mathrm{AgCl}$ as reference while platinum electrode (1.6 $\mathrm{mm}$ dia meter) served as the a uxiliary electrode. The working electrode and the auxiliary electrode were thoroughly cleaned by polishing them with alumina, rinsed with deionized water and a ir dried before each determination.

\section{Calibration Curve}

Stock standard solution of each metal salt was prepared by dissolving weighed amount of the salt [0.1598 $\mathrm{g}$ of $\mathrm{Pb}\left(\mathrm{NO}_{3}\right)_{2}$ and $0.3929 \mathrm{~g}$ of $\mathrm{CuSO}_{4} \times 5 \mathrm{H}_{2} \mathrm{O}$ ] separately in $100 \mathrm{~mL}$ of deionized water to give 1000 ppm of Pband Cu respectively. Serial dilutions were done to get working concentrations of 4000 ppb, 2000 ppb, 1000 $\mathrm{ppb}$ and $500 \mathrm{ppb}$ for $\mathrm{Pb}$ and copper $\mathrm{Cu}$ respectively using $0.1 \mathrm{M}$ acetate buffer, $\mathrm{pH}$ 4.50 conta ining $50 \mathrm{mM}$ nitric acid $\left(\mathrm{HNO}_{3}\right)$, $0.2 \mathrm{M}$ potassium nitrate $\left(\mathrm{KNO}_{3}\right)$, and $80 \mathrm{ppm}$ merc ury (II) nitrate $\mathrm{Hg}\left(\mathrm{NO}_{3}\right)_{2}$. Thestand a rd solutions were used to obta in the calibration curve. $10 \mathrm{~mL}$ each of the standard solution of each metal salt was transferred to the electrochemical cell and purged with nitrogen for $10 \mathrm{~min}$. The pre-concentration of the metal in the standard solution was 
c a rried out at $-900 \mathrm{mV}$ for $120 \mathrm{~s}$ with stiming and after a quiet time of $30 \mathrm{~s}$, the stripping process wascaried out by scanning the potential from $-900 \mathrm{mV}$ to $200 \mathrm{mV}$ using a scan rate of $20 \mathrm{mV} / \mathrm{s}$. Peak currents for lead and copper were observed at -495 $\mathrm{mV}$ and $-19.4 \mathrm{mV}$ respectively.

\section{Analysis of Water Samples for Heavy Metals}

$5 \mathrm{~mL}$ of the digested water sa mple was transferred into the electrochemical cell and $5 \mathrm{~mL}$ of the buffer solution was added and mixed thoroughly. The solution was purged with nitrogen for $10 \mathrm{~min}$. and pre-concentration and stripping were carried out as described for the standard solutions. The peak current obtained at $-495 \mathrm{mV}$ or $-19.4 \mathrm{mV}$ was used to obta in the concentrations of lead or copper respectively in the samples.

\section{Determination of Physico-chemica 7 Parameters of the Water Samples}

The temperature, $\mathrm{pH}$, TDS and EC were determined using a multip robe meter (Hanna HI 98129 Combo waterproof). The determinations were carried out on site. Ac id ity, a lka linity and tota I ha rdness were c a rried out on filtered raw water samples using the methods of the Americ an Public Health Association (APHA, 1998).

\section{Results}

The location of Niger state and the sa mpling stations in Rafi LGA a re shown in Fig. 1. Fig. 2 and 4 show the overlay of the voltammograms obtained for standard solutions of $\mathrm{Pb}$ and $\mathrm{Cu}$. Plots of values of peak current against $\mathrm{Pb}$ or $\mathrm{Cu}$ concentrations are presented in Fig. 3 and 5. Fig. 6 is a n example of a voltammogram obtained for water sample (MAIG/W/5). The coordinates of the sampling sites in Rafi LGA, the concentrations of lead and copper as well as the physico-chemical parameters of the water samples are presented in Table 1.

The results in Table 1 show that $\mathrm{Cu}$ was detected in 8 water samples from Rafi LGA. These levels ranged from $50 \mu \mathrm{g} / \mathrm{L}-679$ $\mu \mathrm{g} / \mathrm{L}$. The maximum permissible limit for copper is $2000 \mu \mathrm{g} / \mathrm{L}(\mathrm{WHO}, 2003)$. Hence the levels of $\mathrm{Cu}$ in these water samples are within safe limit for potable water.

Table 1 also shows the levels of $\mathrm{Pb}$ in the water samples from sites in Rafi LGA. $\mathrm{Pb}$ wasnot detected in sampleMAD/W/2 but eight (8) of the water samples had signific a nt levels of $\mathrm{Pb}$ in the range 50.5 $\mu \mathrm{g} / \mathrm{L}-5916.39 \mu \mathrm{g} / \mathrm{L}$. The permissible limit for $\mathrm{Pb}$ in potable water for adults is $\mathbf{1 0}$ $\mu \mathrm{g} / \mathrm{L}(\mathrm{WHO}, 2011)$ a nd $5 \mu \mathrm{g} / \mathrm{L}$ for child ren (CDC, 2017).

Ponds and borehole exhibited slightly alkaline $\mathrm{pH}$ values which were within the WHO limit of 6.3-8.65. Temperature of the water samples was in the range 29.6 ㅇ -36.6 으 and conductivity of the water sa mples ranged from $81 \mu \mathrm{S} / \mathrm{mL}-1517$ $\mu S / m L$. Elec tric al conduc tivity (EC) is a good measure of dissolved solids. It is a $n$ important criterion in determining the suita bility of a body of water for irrigation (KUMAR; PAL, 2012). Values of EC ranged from $81 \mu \mathrm{S} / \mathrm{mL}-1517 \mu \mathrm{S} / \mathrm{mL}$. 


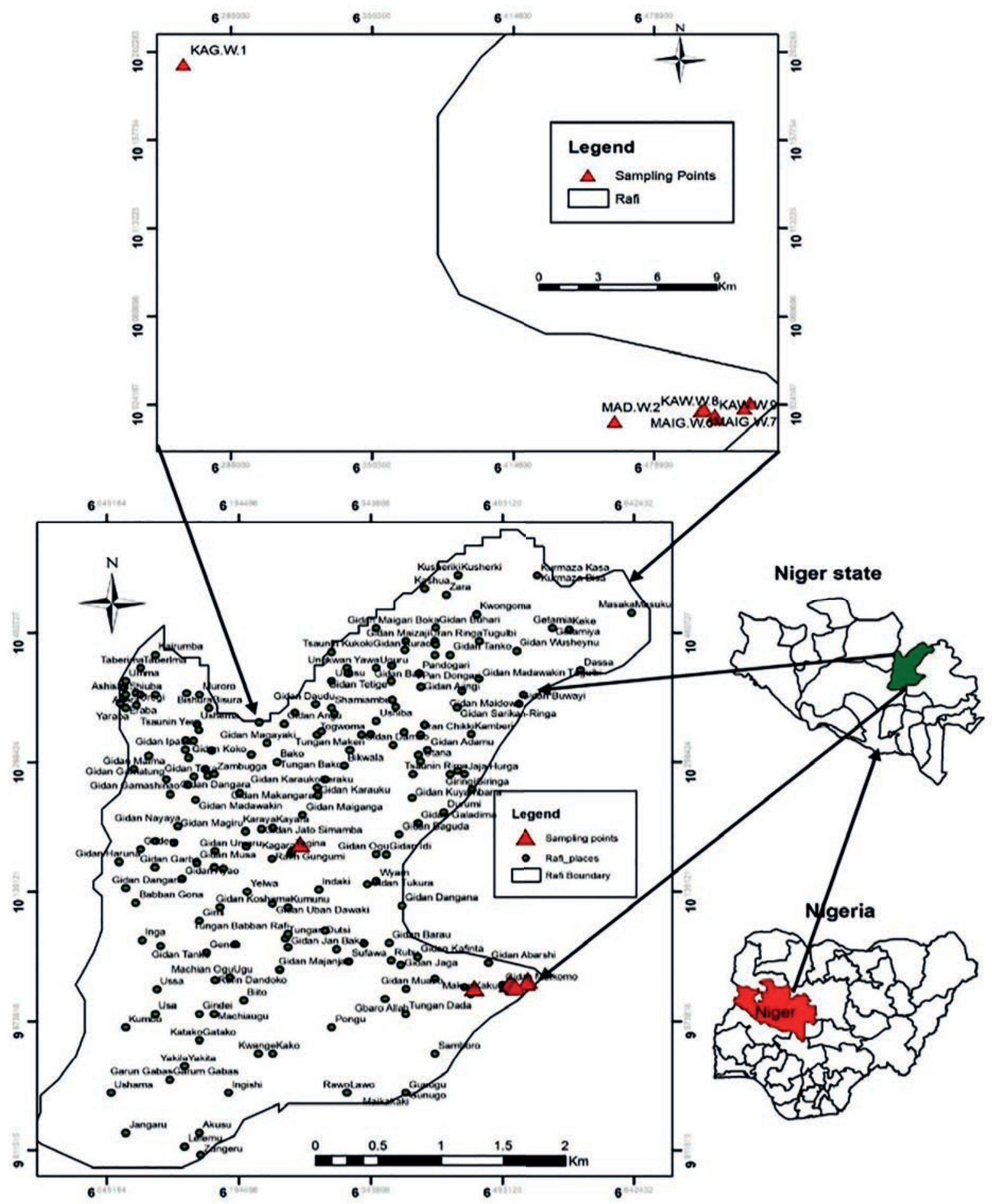

Figure 1 - Composite map of Nigeria showing sampling points inRafi Local Government Area in Niger state. 


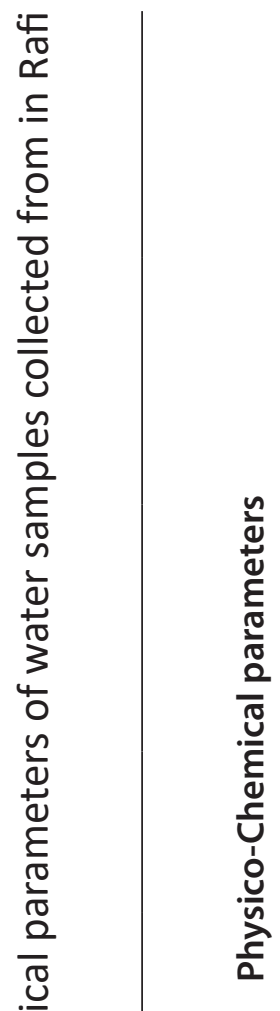

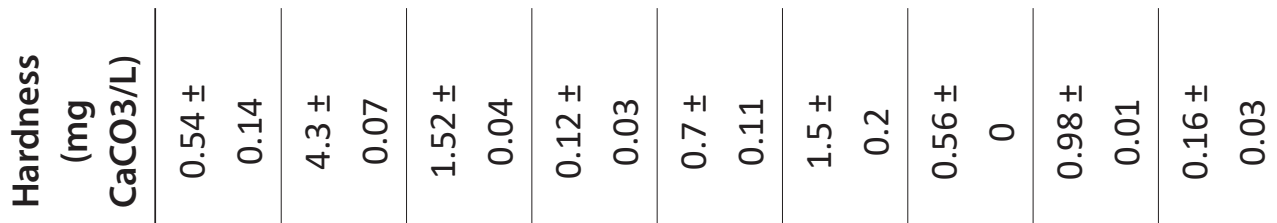

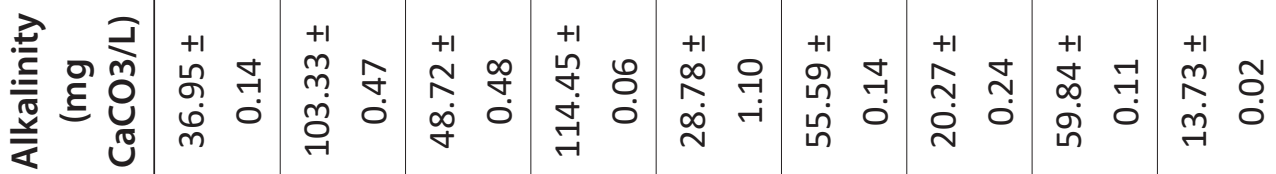

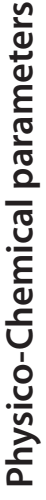

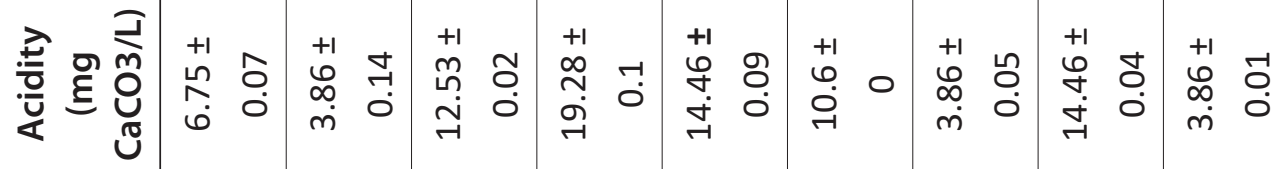

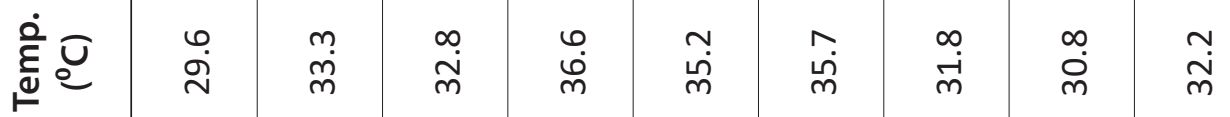

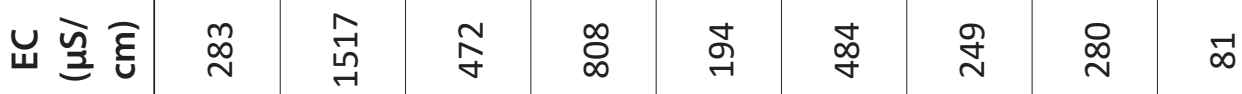

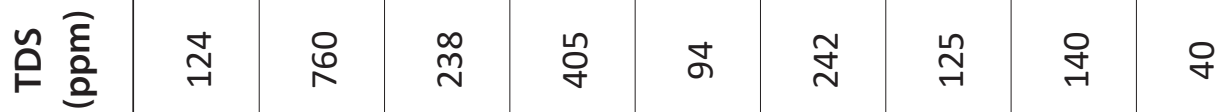

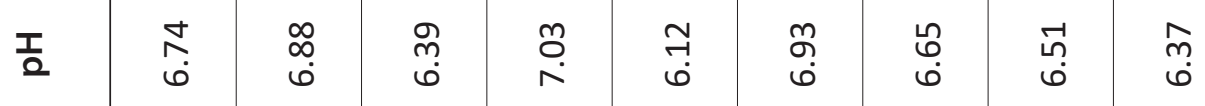

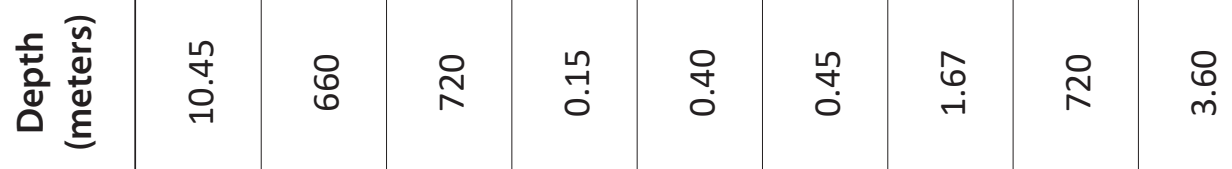

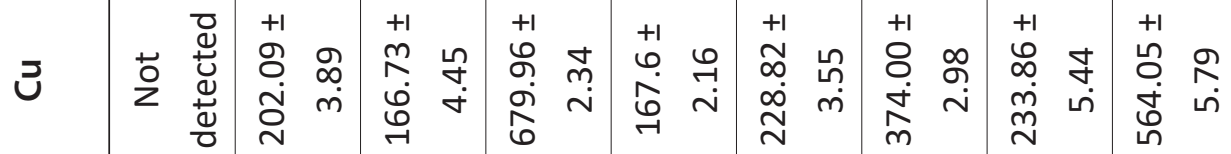

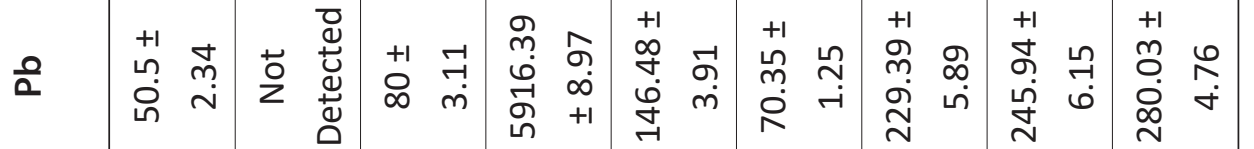
암

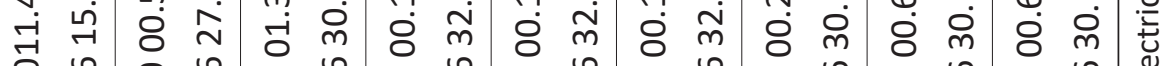

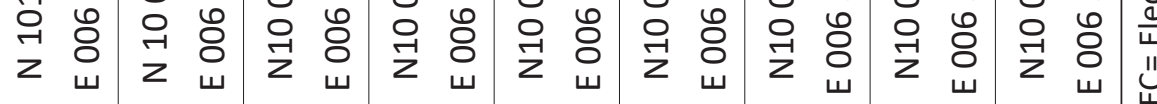

ज部

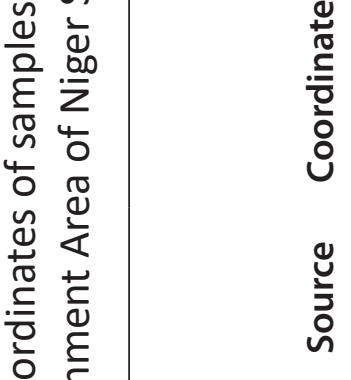

نे

인

응 엄

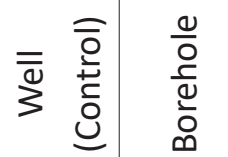 \\ $\sum_{\substack{\frac{1}{3} \\ \frac{1}{3}}}^{\frac{N}{3}}$}

$\frac{0}{0}$

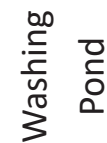

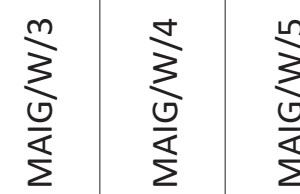

$\frac{\square}{2}$

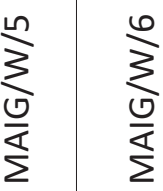

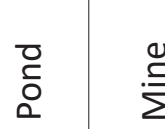

总

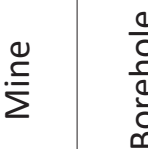

$\sum_{\frac{0}{\Sigma}}^{N} \sum_{\sum}^{\infty}$

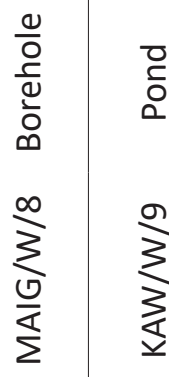




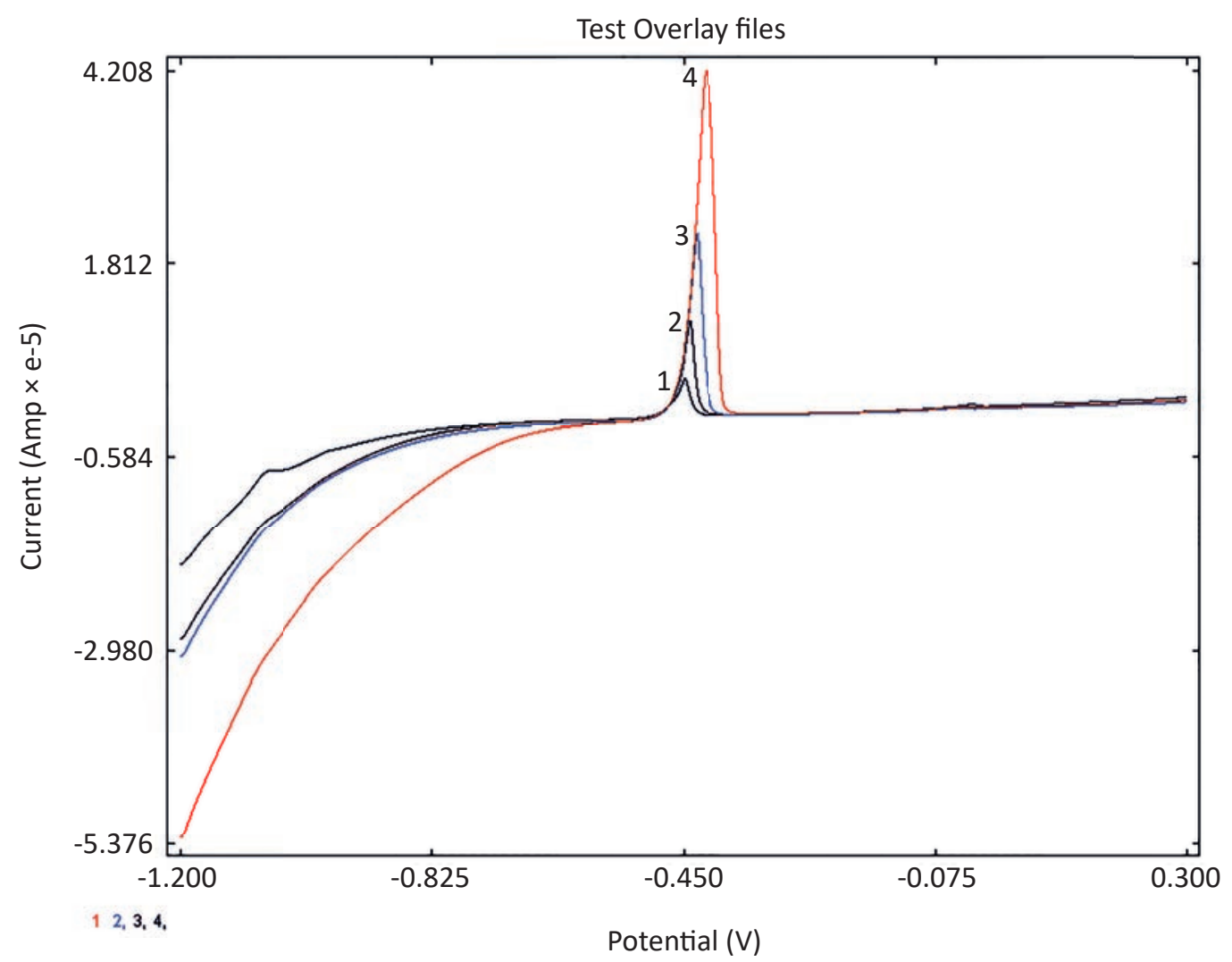

Figure 2 - Overlay of voltammograms obtained for the determination of $\mathrm{Pb}$ in $0.1 \mathrm{M}$ acetate buffer containing $80 \mathrm{ppm} \mathrm{Hg}\left(\mathrm{NO}_{3}\right)_{2}$ and $0.2 \mathrm{M} \mathrm{KNO}_{3}$ at $\left.\mathrm{pH} 4.5\right)$ ( $\mathrm{Pb}$ concentration: 500 ppb (1), 1000 ppb (2), 2000 ppb (3), 4000 ppb (4).

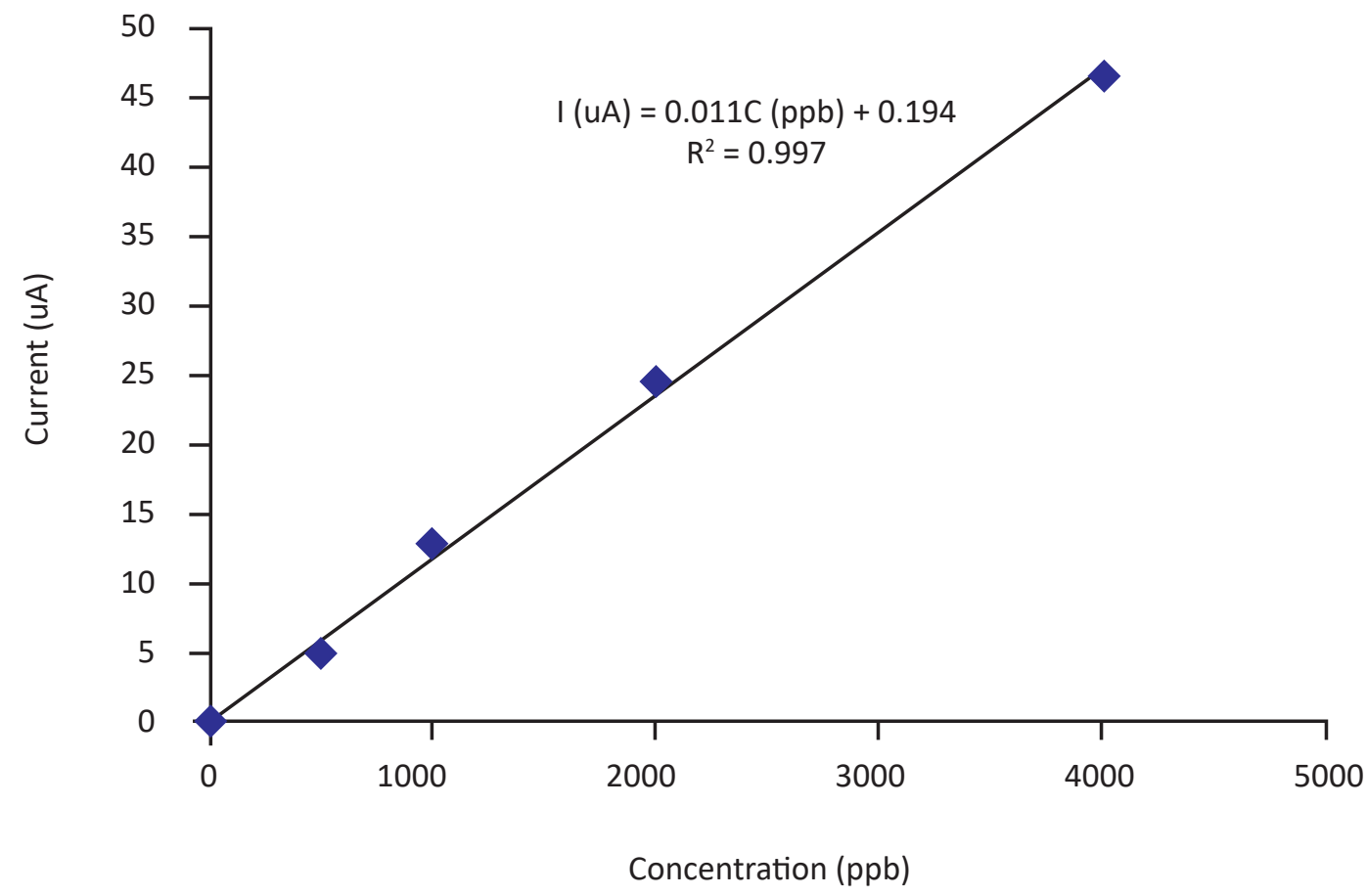

Figure 3 - Lead $(\mathrm{Pb})$ LSSV standard calibration curve: $\mathrm{A}$ plot of peak current against $\mathrm{Pb}$ concentration in background solution. (Pb concentration: $1=500 \mathrm{ppb}, 2=1000 \mathrm{ppb}, 3=$ $2000 \mathrm{ppb}, 4=4000 \mathrm{ppb})$. 
Test Overlay files

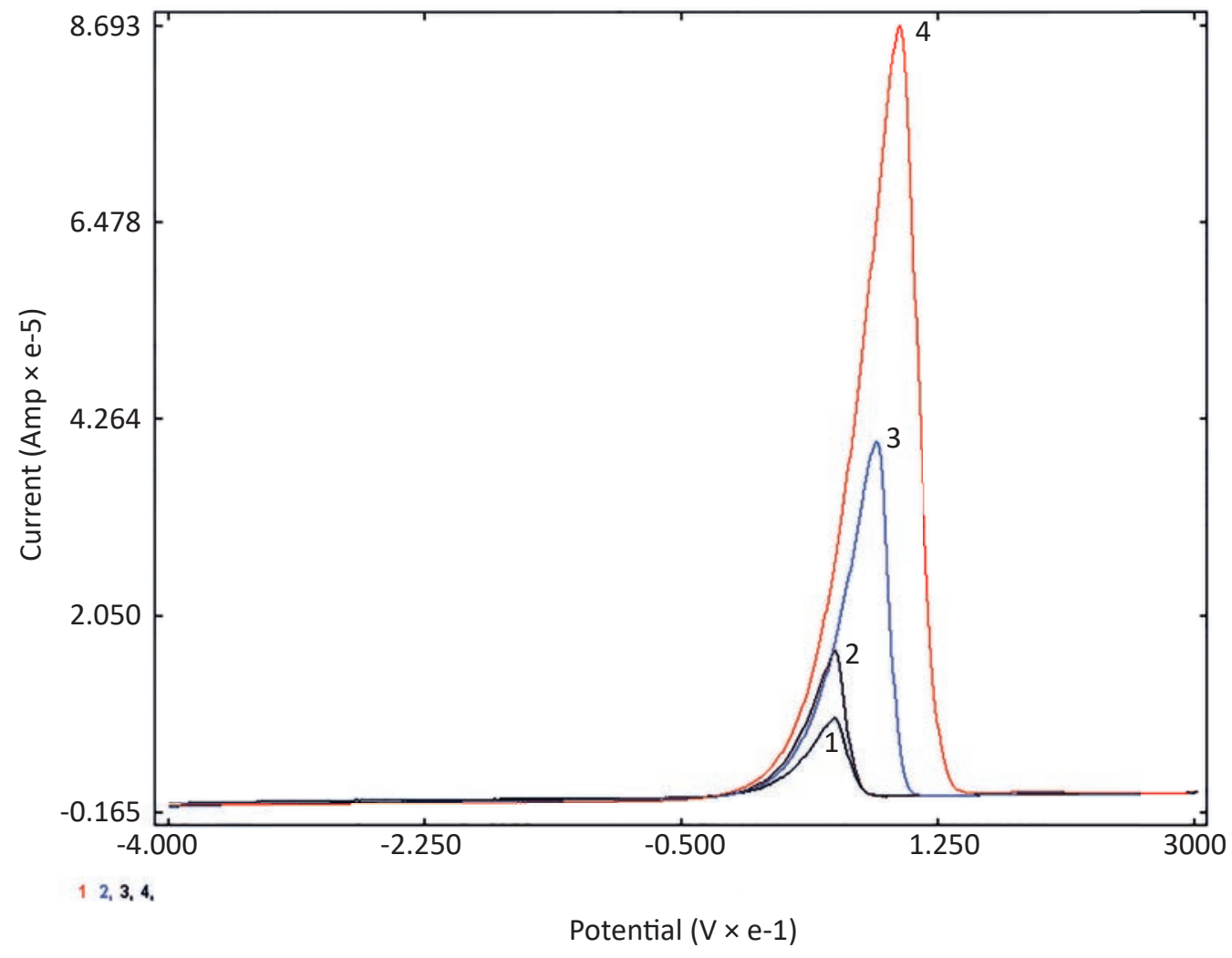

Figure 4 - Overlay of voltammograms obtained for the determination of $\mathrm{Cu}$ in $0.1 \mathrm{M}$ acetate buffer containing $80 \mathrm{ppm} \mathrm{Hg}\left(\mathrm{NO}_{3}\right)_{2}$ and $0.2 \mathrm{M} \mathrm{KNO}_{3}$ at pH 4.5) ( $\mathrm{Pb}$ concentration: $500 \mathrm{ppb}(1), 1000 \mathrm{ppb}(2), 2000 \mathrm{ppb}(3), 4000 \mathrm{ppb}$ (4).

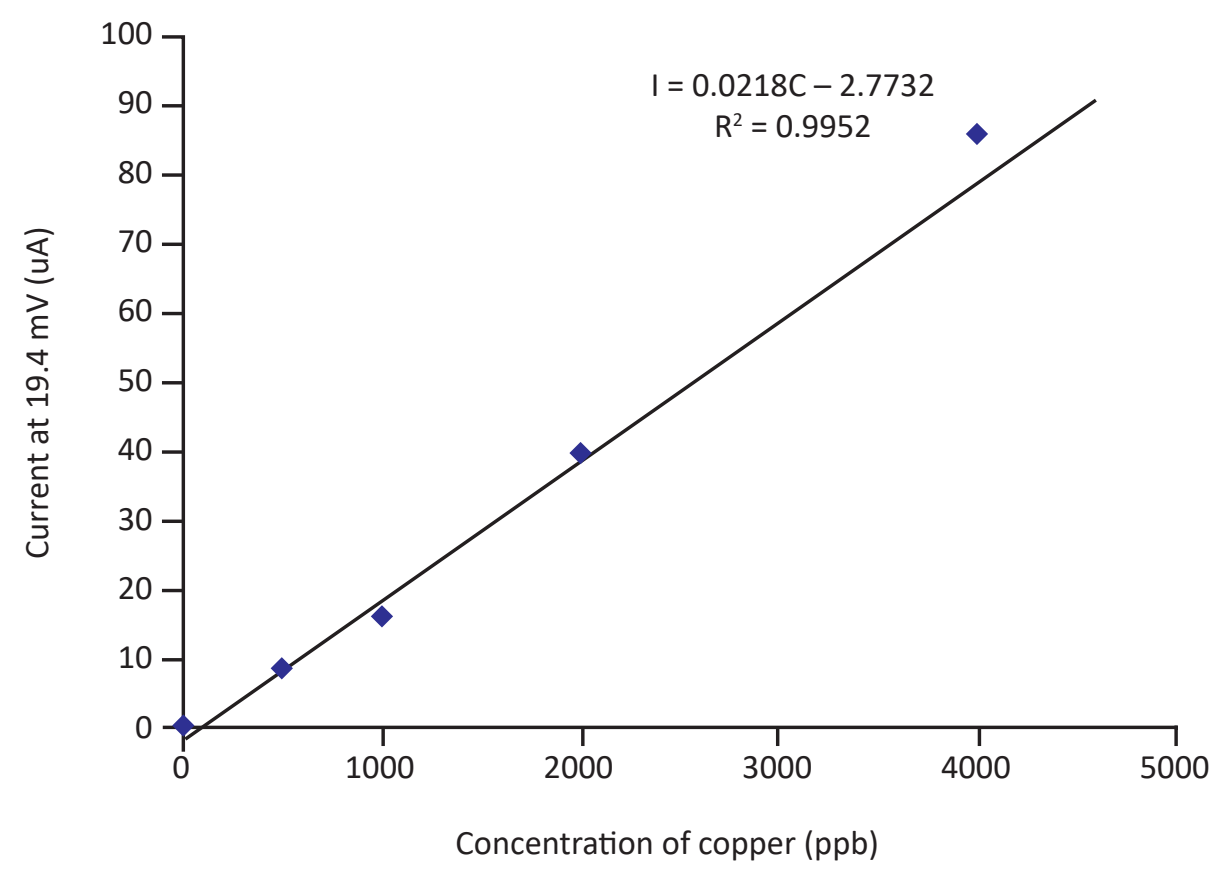

Figure 5 - Calibration plot of peak currents at $19.4 \mathrm{mV}$ against $\mathrm{Cu}$ concentration in $0.1 \mathrm{M}$ acetate buffer $\mathrm{pH}, 4.50$ containing $80 \mathrm{ppm} \mathrm{Hg}\left(\mathrm{NO}_{3}\right)_{2}$ and $0.2 \mathrm{M} \mathrm{KNO}_{3}$. 


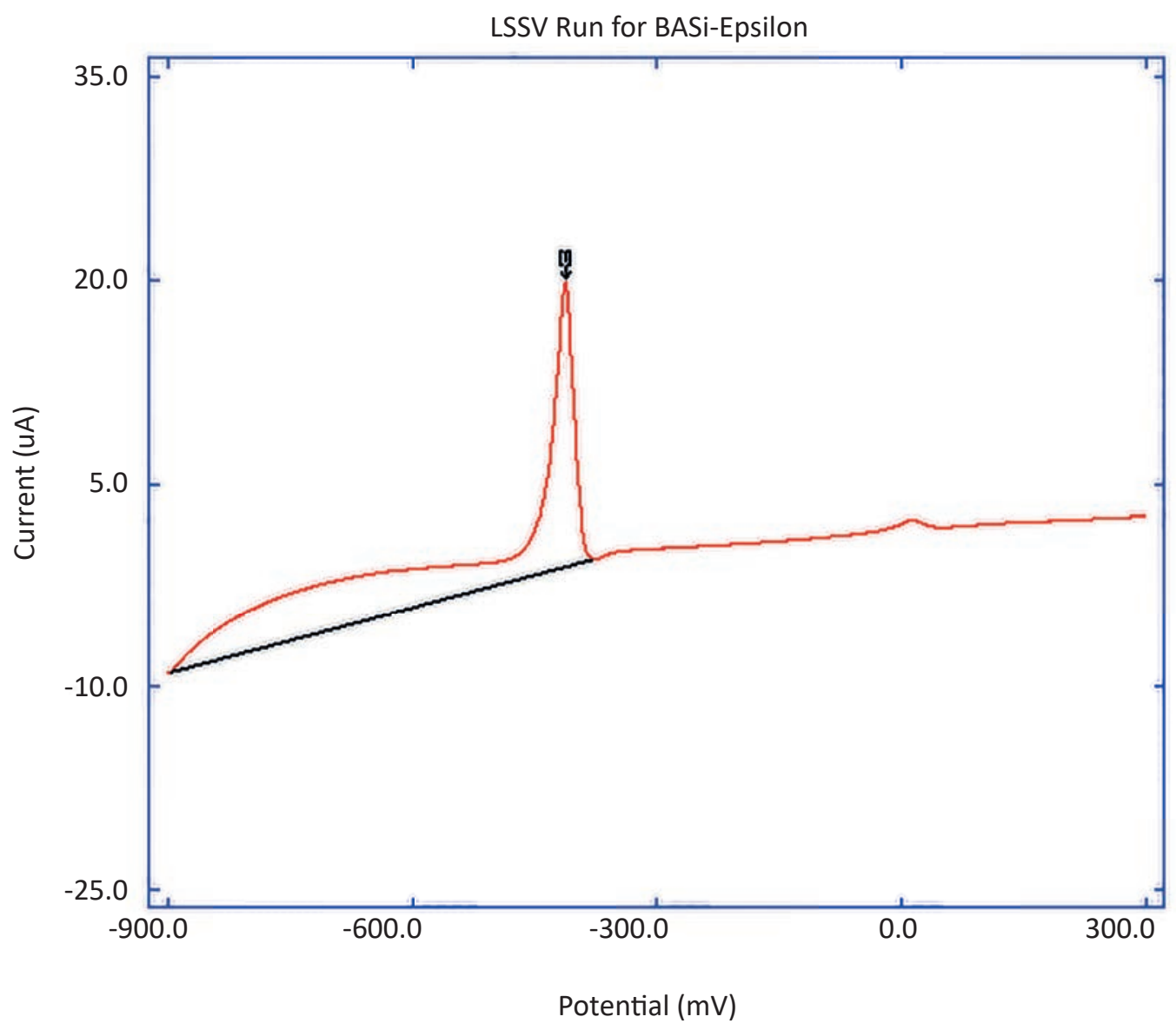

Figure 6 - Voltammogram of water sample MAIG/W/5.

\section{Discussion}

Water samples from Rafi LGA were found to be contaminated by $\mathrm{Pb}$ and $\mathrm{Cu}$. The results presented in Table 1 show $\mathrm{Pb}$ and $\mathrm{Cu}$ contents of the water samples from three boreholes, MAD/W/2, MAIG/W/3 and MAIG/W/8 in Madaka and Maigiro. $\mathrm{Pb}$ was not detected in the water sample from the borehole MAD/W/ 2 but water sample MAIG/W/3 and MAIG/W/8 had Pb levels of $80 \mathrm{\mu g} / \mathrm{L}$ and $245 \mathrm{\mu g} / \mathrm{L}$ respectively. The borehole in Madaka community is 660 meters deep and is situated about 60 kilometers from Kawo and Maigiro where $\mathrm{Pb}$ poisoning was reported. This shows that the ground water a quifer has not been affected by the artisa nal mining operations in Kawo and Maigiro. Hence water from this borehole may be safe for human consumption. It must be noted that no death was recorded in Madaka. The borehole in Madakais about 660 meters deep and covered.

Water sample KAG/W/1 obtained from an open well at the Local Government Hospita lin Kagarawas found to conta in $50 \mu \mathrm{g} / \mathrm{L}$ of $\mathrm{Pb}$. The detection of $\mathrm{Pb}$ in the water sample from this well located $400 \mathrm{~km}$ from mining site is not rea dily explainable but it is probable that miners who visited the hospital for medic al assistance wa shed their hands or clothes with water from this well. The waste water, contaminated 
with $\mathrm{Pb}$ may have drained into the open well. The lack of covering for this well at the hospital signific a ntly puts it at high risk of cross contamination from miners from highly conta minated communities.

The levels of $\mathrm{Pb}$ found in the washing ponds were high. The levels found in the ponds MAIG/W/4, MAIG/W/5, MAIG/W/ 6 and $\mathrm{KAW} / \mathrm{W} / 9$ were $5916 \mu \mathrm{g} / \mathrm{L}, 146$ $\mu \mathrm{g} / \mathrm{L}, 70 \mu \mathrm{g} / \mathrm{L}$ and $280 \mu \mathrm{g} / \mathrm{L}$ respectively. MAIG/W/4 which had the highest lead value in all samples collected exceeded the maximum permissible limit by WHO $(10 \mu \mathrm{g} / \mathrm{l})$ over 590 times (WHO, 2011). This sample was collected from the largest pond where ground gold ore was washed during the floatation process involved in separation of the ore.Domestic a nimals in these communities so metimes consume this wateras nomadic farming is highly practiced in this region. This could have accounted for the deaths of domestic a nima ls in this community (AKO et al., 2014). In rural Nigeria, it is not uncommon to find a nimals and humans drinking water from the same source. Thus, there could be an analogy between human exposures to that of domestic a nimals. Sample MAIG/W/7 obtained from the water body near the mine had $\mathrm{Pb}$ concentration of $229 \mu \mathrm{g} / \mathrm{L}$. This value is over 20 times lower than sample MAIG/W/4 water obtained from the washing pond. Thus excavation of the ore may pose a lesser risk to the community than water bodies such as ponds used for separation of the gold from the ore.
The process of obtaining gold from the ore after excavation sta rts from crushing the main ore to pebbles which helps to inc rease the surface area. Second stage involves the grinding of the pebbles into fine particles which further inc reases the surface area. This is norma lly ca rried out in the homes of miners by wo men and children. It expla ins the greater risk of exposure of women and infants to $\mathrm{Pb}$. Infants ingest the ores when they suck their hands or eat with unwashed hands. In addition to exposure through water, exposure also occurs through inhalation in the first and sec ond stages of ore processing. It has been shown that inhalation or ingesting of contaminated soil, dust, a ir, or water near mining sites, eating conta minated food grown on soil containing lead or food covered with lead-conta ining dust could result in lead toxic ity (NABILAH, 2014). Third stage which is washing of the fine partic les of the ore leads to dissolution of the complexed $\mathrm{Pb}$ and hence becomes available in the water bodies used for its washing as evidenced in the high value of $\mathrm{Pb}(5916 \mu \mathrm{g} / \mathrm{l})$ in MAIG/W/4 obtained from the main washing pond in Maigiro. Water from the borehole MAD/W/2 sampled in this study did not conta in lead which suggests that the pollution most likely remains confined to a reas where processing had taken place and has not spread throughout the groundwater aquifer. This also suggests water bodies which are covered are likely to be less contaminated and will be more suitable for drinking in these communities. 
There is limited information on ind irect so urc es of exposure in this a rea, however a recent study reported a prevalence rate of $100 \%$ was reported in kidney and liver samples from cattle sla ughtered in So koto Central a batto ir (BALA et al., 2012).

No mines were observed in Maigirobut inhabitants of this town travel to Kawo to excavate gold-containing ores. As mentioned above, three stages are involved in ore processing and could all result in the pollution of the environment.

There a re limited studies on the newly emerged problems of mining in Niger state, though, the dangers of $\mathrm{Pb}$ poisoning through this relatively new economic activity in the sta te emphasize the risk to the health of the community. Socioeconomic factors associated with this problem could be non-availability of pipe borne water, overcrowding, poverty, negligence, lack of a wareness and unemployment.

Children a re especially prone to the adverse effects of $\mathrm{Pb}$ and as a result blood $\mathrm{Pb}$ levels have been set lower ( 5 $\mu \mathrm{g} / \mathrm{L})$ (CDC, 2017) and should be regularly monitored where children are exposed. $\mathrm{Pb}$ is dangerous to young children because their bodies and brains a re developing. Young bodies also a bsorb more $\mathrm{Pb}$ than adults. The small intestine of a developing child responds to nutritional needs by inc rea sing the absorption of specific nutrients. $\mathrm{Pb}$ absorption affects the development of young children by causing speech delay, hypera c tivity, attention defic it disorder, lea ming disa bilities, beha vio ra I disorders, neurological and renal damage, stunted growth, a nemia, hearing loss, mental retardation and at high doses death just as was seen in the $\mathrm{Pb}$ poisoning epidemic s in Zamfara state in J une, 2010 and Rafi LGA of Niger state in J une, 2016. Investiga tions of the Zamfara state $\mathrm{Pb}$ poisoning epidemic revealed that the lead poisoning was widespread. Thousands of child ren had dangerous levels of $\mathrm{Pb}$ in their blood, and hundreds of children and a nimals had died throughout the region. It was the la rgest known outbreak of lead poisoning in history according to Centre for Disea se Control (CDC, 2010).

\section{Conclusion}

All samples exc ept one had Pb levels above the WHO maximum permissible limit $(10 \mu \mathrm{g} / \mathrm{L})$, with MAIG/W/4 exceeding this limit over 590 times. The high levels of $\mathrm{Pb}$ in the water samples suggest high level of pollution caused byartisanal mining activities, leading to a discharge of the potentially toxic metals into the water bodies. The consumption or contact with the contaminated water bodies may have been responsible for the $\mathrm{Pb}$ poisoning epidemic which has claimed dozens of lives especia lly those of c hild ren in Rafi LG A of Niger State. Remediation procedures should be planned out and put in motion to quickly tackle the effect of this poisoning on huma $n$, livesto $c k$ and the environment. 


\section{References}

ADEGBOYE, M.A., 2013. Journal of Science and Environmental Management, vol. 3, pp. 77-83.

AKO, T.A., ONODUKU, U.S., OKE, S.A., ADAMU, I.A., ALI, S.E., MAMODU, A. and IBRAHIM, A.T., 2014. Environmental Impact of Artisanal Gold Mining in Luku, Minna, Niger State, North Central Nigeria. Journal of Geosciences and Geomatics, vol. 2, no. 1, pp. 28-37.

APHA (American Public Health Association), 1998. Standard methods for the Examination of Water and Waste water, $20^{\text {th }}$ Edition, Washington DC.

AROGUNJO, A.M., 2007. Heavy Metal Composition of Some Solid Minerals in Nigeria and Their Health Implications to the Environment. Pakistan Journal of Biological Sciences, vol. 10, pp. 4438-4443. https:// doi.org/10.3923/pjbs.2007.4438.4443

BALA, A., JUNAIDU, A.U., SALIHU, M.D., ONIFADE, K.I., MAGAJI, A.A., FALEKE, O.O., SAULAWA, M.A., MUSAWA, A.I., MOHAMMED, M., MUHAMMAD, L.U., PEWAN, S.B., ANZAKU, S.A. and EMENNA, P., 2012. Survey of Lead $(\mathrm{Pb})$ Residue in Kidney and Liver of Slaughtered Cattle in Sokoto Central Abattoir, Sokoto State, Nigeria. Journal of Veterinary Advances, vol. 2, no. 3, pp. 132-138.

CDC (Centers for Disease Control), 2012. CDC Advisory Committee on Childhood Lead Poisoning Prevention. Low Level Lead Exposure Harms Children: A renewed call for primary prevention. Atlanta, GA: US Department of Health and Human Services.

CDC (Centers for Disease Control), 2010. Lead Poisoning Investigation in Northern Nigeria. Available in: https://www.cdc.gov/onehealth/in-action/leadpoisoning.html. Accessed: 23 ${ }^{\text {rd }}$ October, 2017.

CDC (Centre for Disease Control and Prevention), 2017. New lead information. National Center for Environmental Health. Division of Emergency and Environmental Health Services.

JAN, A.T., AZAM, M., SIDDIQUI, K., ALI, A., CHOI, I. and HAQ, Q.M.R., 2015. International Journal of Molecular Sciences, vol. 16, pp. 29592-29630.

JUNG, M.C. and THORNTON, L.T., 1996. Applied Geochemistry, vol. 11, p. 53.

KUMAR, J. and PAL, A., 2012. Water quality monitoring of Ken River of Banda District, Uttar Pradesh, India. Elixir Pollution, vol. 42, pp. 6360-6364.
MARTINEZ-FINLEY, E.J., CHAKRABORTY, S., FRETHAM, S. and ASCHNER, M., 2012. Metallomics, vol. 4, pp. 593-605.

MINING AFRICA, 2017. The Nigerian Mining IndustryAn Underdeveloped Industry. Available in: http:// www.miningafrica.net/mining-countries-africa/ nigeria/. Access: Oct. 2017.

NABILAH D., 2014. Survey of lead poisoning in small ruminants and ducks in Anka local government area of Zamfara state, Nigeria. MSc. Thesis. Department of Veterinary Public Health and Preventive Medicine, Faculty of Veterinary Medicine, Ahmadu Bello University, Zaria.

NIRMAL KUMAR, I., SAJISH, P., NIRMAL, R., BASIL, G. and SHAILENDRA, V., 2011. An Assessment of the Accumulation Potential of $\mathrm{Pb}, \mathrm{Zn}$ and $\mathrm{Cd}$ by Avicennia marina (Forssk.) Vierh. In Vamleshwar Mangroves, Gujarat, India.World Journal of Fish and Marine Sciences, vol. 2, no. 5, pp. 450-454.

OKIEI, W., OGUNLESI, M., ADIO-ADEPOJU, A. and OLUBOYO, M., 2016. Determination of Copper and Lead in Water Samples from Zamfara State, Nigeria by Linear Sweep Anodic Stripping Voltammetry. Int. J. Eletrochem. Sci. vol. 11, pp. 8280-8294. DOI 10.20964/2016.10.06

PEPLOW, D., 1999. Environmental Impacts of Mining in Eastern Washington, Center for Water and Watershed Studies Fact Sheet, University of Washington, Seattle.

PREMIUM TIMES, 2015. Investigation: Shikira: Community where 28 children die from lead poisoning. Available in: https://www.premiumtimesng. com/investigationspecial-reports/185765investigationshikira-community-where-28-childrendie-from-lead-poisoning.html

ROCK, O., OKEKE, O.C. and ABRAHAM, E., 2015. Environmental Problems of Surface and Underground Mining: a review. The International Journal of Engineering And Science. vol. 4, no. 12, pp. 12-20.

SNEHA, G., ADITYA, K. and BASANT, K., 2012. Opencast mines: a subject to major concern for human health. International Research Journal of Geology and Mining, vol. 2, no. 2, pp. 25-31.

SWEET CRUDE REPORTS, 2016. Illegal mining in focus as lead poisoning ravages communities in Niger State. Available in: http://sweetcrudereports. com/2016/04/06/illegal-mining-in-focus-as-leadpoisoning-ravages-communities-in-niger-state/. Access: Oct. 2017. 
VEIGA, M.M., 2003. Mercury in artisanal gold mining in Latin America: facts, fantasies and solutions, UNIDO Expert Group Meeting- Introducing new technologies for abatement of global mercury pollution deriving from artisanal gold mining, Vienna, Austria.

WHO, 2011. Guidelines for Drinking-water Quality (GDWQ). Geneva, World Health Organization. (WHO/SDE/WSH/03.04/09/Rev/1). Available in: http://www.who.int/water_sanitation_health/dwq/ chemicals/lead.pdf
WHO, 2003. $p H$ in drinking-water. Background document for preparation of WHO Guidelines for drinking-water quality. Geneva, World Health Organization (WHO/SDE/WSH/03.04/12). 



\section{'Natal' Orange (Citrus sinensis L. Osbeck) Growing Simulation Model Under Climate Change Conditions}

Pereira, F.F.S. ${ }^{1 *}$, Queluz, J.G.T. ${ }^{2}$, G onzález, A.M.G.O. ${ }^{1}$, Sánchez-Román, R.M. ${ }^{3}$

1Postdoctoral Resea rcher, Rural Eng ineering Department, School of Agriculture, Sã o Pa ulo Sta te University - UNESP, Botucatu, SP - Bra zil.

2Postdoctoral Resea rcher, Petrology and Metallogeny Department, Institute of Na tura I Sc iences and Technology, São Paulo State University - UNESP, Rio Cla ro, SP - Bra zil.

${ }^{3}$ Assistant Professor, Rura I Engineering Depa rtment, Scho ol of Agric ulture, Sã o Pa ulo State University - UNESP, Botucatu, SP - Brazil.

*Corresponding a uthor: fra ncianasousap@gmail.com

\section{Abstract}

The main objective of the research was to develop a model based on dynamic systems. The model was developed through a systematic analysis of the factors that interfere in the formation of crop biomass. It was determined as ma in variables: $\mathrm{CO}_{2}$, a ir temperature, tra nspira tion, precipitation, wa ter defic it, irrigation water depth, canopy cover and their interrelations. The time step used for the simulations and applied was determined by the crop cycle, allowing a time frame from 2010 to 2100. The model hasall the variables that are being able to be quantified, pursuing results closer to reality. In general, the results showed that the rising of $\mathrm{CO}_{2}$ concentrations in the atmosphere combined with higher temperatures will promote greater effic iency of water use by this orange variety. Otherfactors were added such soil water defic it; it was verified that a reduction in the water productivity parameter for non-irrigated condition will be considerably higher than the irrigated condition by 2100 . It was 
concluded that the model, here presented, was able to determine the influence of climate, especially future $\mathrm{CO}_{2}$ concentrations in a ir temperature changes in the water productivity parameter for $\mathrm{Nata}$ I orange. Rising $\mathrm{CO}_{2}$ concentrations in the atmosphere will influence positively the assimilation of $\mathrm{CO}_{2}$ by the Natal orange and, therefore, a increase in gram per millimeter transpired by the orange tree. However this positive effect may be masked by the effects of other va riables such as a ir temperature.

Keywords: system dynamic s, water reso urces, a gric ultura I production and climate va riability.

\section{Introduction}

The current climate changes occur mainly due to the high concentrations of gases in the atmosphere. Data from the Intergovemmental Panel on Climate Change - IPC C (2014), show that carbon dioxide $\left(\mathrm{CO}_{2}\right)$ concentration in the a tmosphere has increased by $40 \%$ between 1750 and 2011, and its concentration tends to increase in the future. (STC $\mathrm{H}$ et al., 2008, IPC C, 2014).

There are several factors that influence the uptake of $\mathrm{CO}_{2}$ by crops. Delgado et al. (2010) states that the water availability as the main factor. According to Ribeiro Machado (2007) and Ribeiro et al. (2009), if the hydric conditions are right, the most important factors that will influence, over the year, the photosynthesis of orange are: changes in a ir and soil temperature, day length and the plant's development stage.

With the concern of the influence of climate changes on a gricultural productivity, there is a growing interest to understand the processes and factors of soil-plant-a tmosphere system caused by increases in atmospheric $\mathrm{CO}_{2}$ concentrations and changes in a ir temperature. In the literature there are models to evalua te the behavior of herbac eous crops in relation to climate change as, for example, the AquaCrop, which was developed from the reassessment and restructuring of the report 33 from the Food and Agriculture Organization of the United Nations - FAO (DO O RENBO S e KASSAN, 1979; STEDUTO et al., 2009; RAES et al., 2009). However, when the desired responses a re tree crops with long cycles, such ascitrus, it is important to enhance the studies, and modeling is a possibility. It is necessary, therefore, a method that interconnects both the climatic factors and the crops yields behavior over the years. Thus, this study fits perfectly in the System Dynamics methodology. Considered by Capra (1996) as a new way of expressing the chains of existing cyclic events in nature, a nalyzing them always in an integrated manner.

Thus, the a im of the study was to develop a simulation model for the orange (C itrus sinensis L. Osbeck) growth in relation to climate changes, based on the principles of system dyna mic s to verify the effects of climate change and va riability and its implic a tion on the water use efficiency by the citriculture in the region of Sã o J osé do Rio Preto, Sta te of Sã o Paulo, Brazil, mediated by changes in 
$\mathrm{CO}_{2}$ concentrations and a ir temperature variations.

\section{Material and Methods}

The dynamic simulation model of the water use efficiency for tree crops, especia lly citrus (MSE-C itrus), was developed with foc us on system dyna mic s using STELLA 10.0.5 platform. A systematic a nalysis of the production process and formation of citrus yield was performed, considering the existence of models that simula te the biomass formation of herbac eous cultures in cond itions of c lima te change, such as Aqua C rop (STEDUTO et al., 2009; RAES et al., 2009). It was possible from then, to integrate previously developed researchesand use these models for tree crops due to lack of models for citrus.

\section{a) Structure of the simulation model of the water use efficiency by citrus (MSE-Citrus)}

The conceptual diagram (Figure 1) shows the major variables involved in the yield formation, which was the source for the model development.

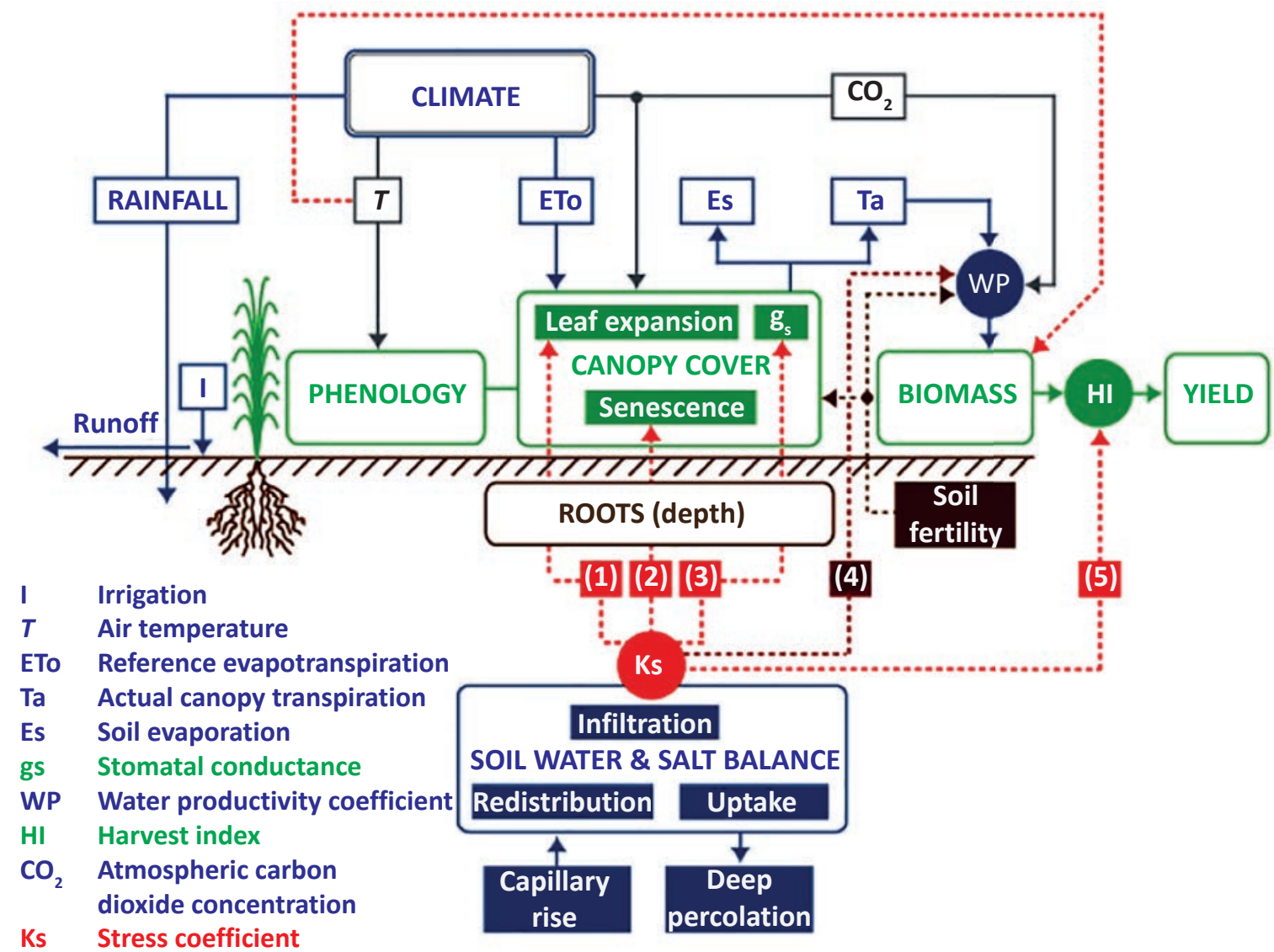

(1), (2), (3), (4), (5): Feedbacks/Feedforwards from water stress

Figure 1 - Conceptual diagram of the yield formation process (adapted from RAES et al., 2012). 
The initial steps include the identification of the elements, their interrelationships and processes that constitute the biomass formation process, mainly the $\mathrm{CO}_{2}$ concentrations in the atmosphere, the relationship of these concentrations with the a ir temperature and its influence on the water use efficiency by the citric ulture. Then the model struc ture was represented in a causal diagram, also called diagram of influences (Figure 2).

In Figure 2 is shown the interrelations between the major variables involved, the water use efficiency and the $\mathrm{CO}_{2}$ are the variables that cause ma in accumulations in the system. The reference evapotranspiration (ETo) and tra nspiration (Tr) a re the variables that quantitatively influence the behavior of water use effic iency and Biomass is the main stock that accumulates in the system. The water use efficiency and biomass receive water during the biomass formation process; $\mathrm{CO}_{2}$ also has a strong influence on the formation of biomass and water use efficiency, acting as a source in the carboxylation process. The ETo and Tr fill or empty the major stocks and, therefore, act as fluxes.

Existing feedback loops between the system components a re characterized by the following points: the increase in $\mathrm{CO}_{2}$ concentration will increase the water use efficiency $(+)$, the same occurs with the inc rease in transpiration which will cause $a n$ increase in biomass and therefore will cause an increase in the water use efficiency (+), and an increase in ETo reduces the water use efficiency (-). The relation between biomass and transpiration shows the same response $(+)$, note that it is a positive reinforcement.

From the causal c ircle (Figure 2) was developed the diagram of stocks and flows, shown in Figure 3, which allows us to describe the system operation in a more detailed way. Thus, it was possible to perform the mathematical simulation of the water use efficiency by orange crop.

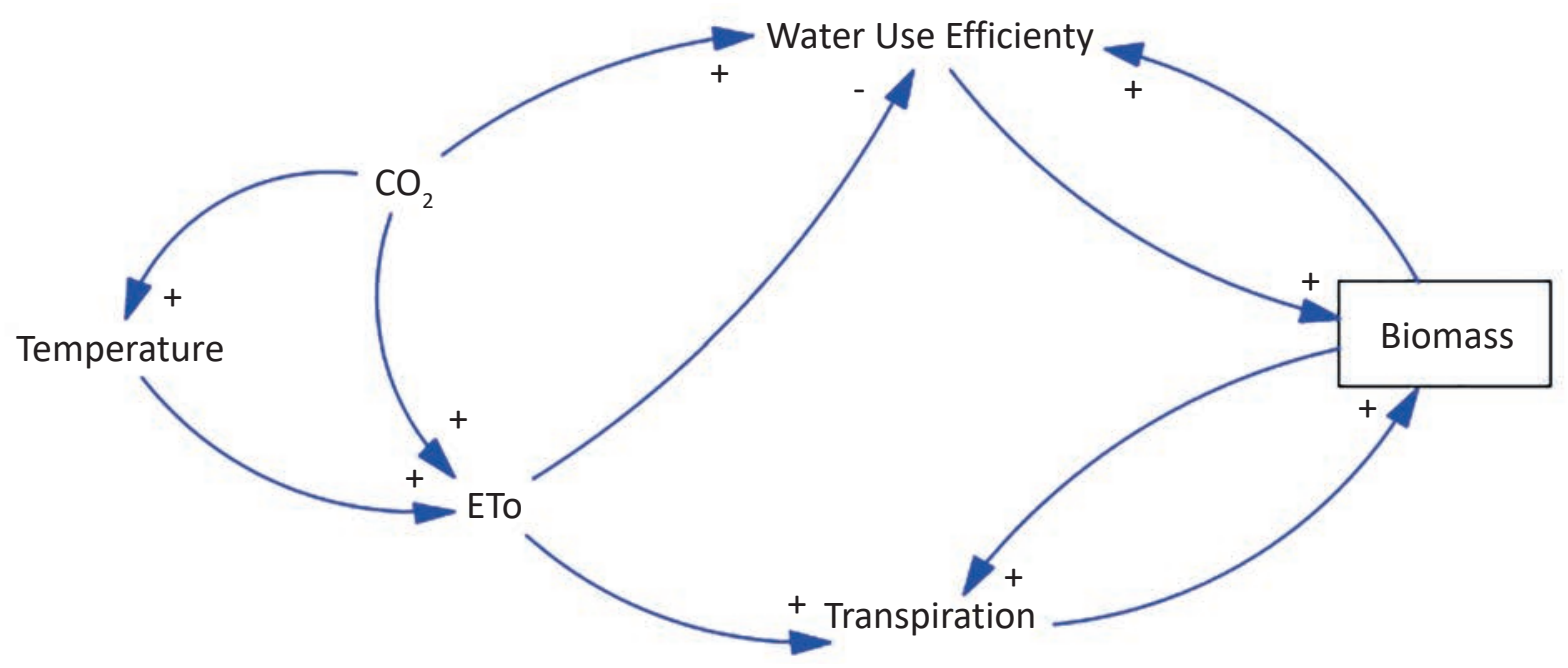

Figure 2 - Causal diagram of the developed model (adapted from PEREIRA; SÁNCHEZROMÁN; ORELLANA GONZÁLEZ, 2017). 
'Natal' Orange (Citrus sinensis L. Osbeck)...

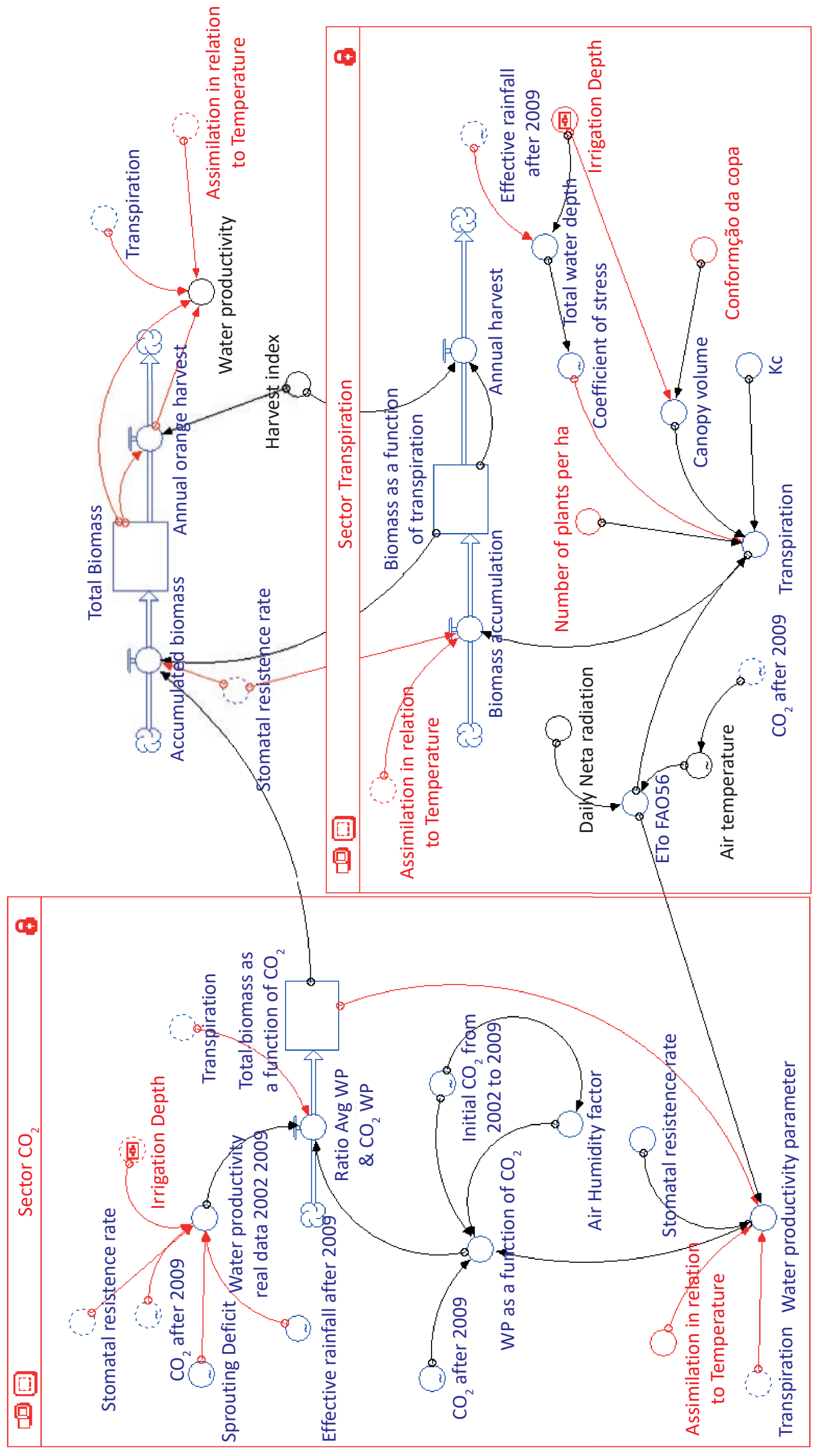

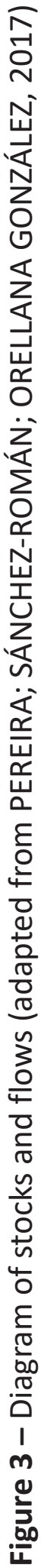


b) Mathematica 1

\section{basis for the}

development of MSE-

\section{citrus}

Was used to calc ulate the water use efficiency (WP) the methodology desc ribed in papers published by FAO (STEDUTO, HSIAO e FERERES 2007; RAES et a I., 2009; RAES et al., 2012). Equations 1, 2 and 3 were fundamental to the WP calculation, and also for the normalization of $\mathrm{CO}_{2}$ concentrations in the atmosphere.

$$
W P=\left(\frac{B}{\sum \frac{\operatorname{Tr}}{E T o}}\right)\left[\mathrm{CO}_{2}\right] \quad \text { Eq. } 1
$$

Where:

B: Total Biomass, $\left(\mathrm{Kg} \mathrm{m}^{-2}\right)$;

WP: Water use efficiency $\left(\mathrm{Kg} \mathrm{m^{-2 }}\right.$ $\mathrm{mm}$ ) kilogram of biomass per square meter and per millimeter of water transpired, or kilogram of biomass per cubic meter of water transpired;

Tr: Crop transpiration (mm);

ETo: Reference evapotranspiration $(\mathrm{mm})$;

$\mathrm{CO}_{2}: \mathrm{CO}_{2}$ concentration in the atmosphere (ppm).

Transpiration was calcula ted using Equation 2, proposed by Raes et al. (2009).

$$
\operatorname{Tr}=K s * D * \% C C * K C_{t r x} * \text { ETo Eq. } 2
$$

Where:

Ks: Drought stress coefficient (decimal);

\%CC:C a nopy volume (decimal);

$\mathrm{KC}_{\mathrm{Tr}}$ : Kc of the maximum transpiration (a dimensional);

ETo: Reference evapotranspiration (mm).
All the complex metabolic processes of the $\mathrm{CO}_{2}$ fixation a re considered in the parameters of the equations 3 e 4 , described in the work of Steduto, Hsia o e Fereres (2007).

$$
W P=W P_{b} \frac{C_{a, o}}{C_{a}} * D
$$

Where:

WP: Water use Efficiency as a function of $\mathrm{CO}_{2}$ concentrations $\left(\mathrm{g} \mathrm{m}^{-2} \mathrm{~mm}^{-1}\right)$,

$W_{b}$ : Biomass water use efficiency (data provided by Citrosuco company) $\left(\mathrm{g} \mathrm{m}^{-2} \mathrm{~mm}^{-1}\right)$;

$c_{a, o}$ : Annual average concentration of $\mathrm{CO}_{2}$ in the atmosphere measured by Mauna Loa Observatory (Havaii), for the reference year

$c_{a}:$ Annual average concentration of $\mathrm{CO}_{2}$ in the atmosphere measured by Mauna Loa Observatory (Havaii), for the year in which the biomass is produced;

D: Empiric al factor originated from an approximation of the sum of $\Delta w$, that is the sum of the difference in the concentration of water vapor between the intercellular air space and the atmosphere in a given situation $(\Delta W)$ and in a reference situation $(\Delta W O)$

Sted uto, Hsia o, Fe re res (2007) recommend that $D$ shall be obtained by Equation 4, where $C_{a, 0}$, is taken as a reference value equal to $360 \mathrm{ppm}$.

$$
D=a-b \times\left(C_{a}-C_{a, o}\right) \quad \text { Eq. } 4
$$

Where:
a: 1.
b: 0,000138 
For the determination of the coeffic ients a and b of equation 4, Steduto, Hsiao e Fereres (2007) performed experiments in chambers under controlled conditions of $\mathrm{CO}_{2}$ emissions, and other parameters related to the conditions of vapor sa turation pressure, a ir tempera ture and humidity. Furthermore, the a uthors suggest that Equation 4 could be used for the sta nda rd iza tion of d ifferent concentrations of $\mathrm{CO}_{2}$ in the atmosphere.

\section{c) Information source for the use of MSE-Citrus}

After developing the model, were obtained data from consecutive years of biomass formation for the orange $c$ ro $p$ in non-irigated condition, to check if the structured model can simulate water use efficiency values close to the values provided by FAO for $\mathrm{C}_{3}$ plants ( 15 to $20 \mathrm{~g} \mathrm{~m}^{-2} \mathrm{~mm}^{-1}$ ).

The planting of the crop wascaried out in 1998 and the data of biomass formation were collected since 2002 , when the crop was five years old.

The stress coefficient (Ks) was calculated for each yearwith the water a mount resulting from ra infall. The climate database, the rainfall in the two farms, whic $h$ formed the basis for the simulation model was obtained from the Department of Water and Power of the State of São Paulo (DAEE). Data for potential evapotranspiration were obtained from the Agronomic Institute of Campinas (IAC).

\section{d) Calculation of} water use efficiency parameter - WP

With orange biomass formation data provided by the Citrosuco company, the total biomass was calculated. The biomass data provided correspond to the useful orange biomass, i.e. the fruit. To convert these values in total biomass was used a conversion factor based on previous researches, that determined what percentage of orange trees correspond to useful biomass (MATTOS J UNIOR et al., 2003).

The variable canopy volume (Vc) was obtained by values established in the literature (QUAGIO et al., 2004; GRAÇA et al., 2001; STUCHI e DONADIO 2000; LEDO et al., 1999). According to Levy, Bielora, Shalhevet (1978) a nd Romero et a I. (2006), in c itrus orchards conducted in ra infed condition, it happens $41 \%$ reduction in canopy volume, from these growth reduction coeffic ients and values of canopy volume percentages, was applied the percentage reduction in the non-irrigated a rea. With the canopy volume, it is possible to determine the transpiration per plant. From the determination of the tranpiration and with the number of plants perhectare, it is determined the amount of water transpired a nnually per hec ta re in irrigated and unirrigated conditions.

To obtain the equa tions that guided the STELLA software, were evaluated the data provided by the Citrosuco company, and it was rea lized that the yields were influenced by some variables, for example, 
the water defic it that occurred in the sprouting period was influenced by weather conditions and the crop cycle. The water defic it was obtained by performing the calculation of the water balance in the period in which the biomass formation data was obtained (2002 to 2009).

The biggest water defic it occur a nnually in the period between the second ha If of May up to first half of August, moment that begins the replacement of evapotranspired water with the use of irrigation in the area conducted under irrigation. From the analysis of the biomass formation, it wascreated a multiple linear correlation.

The multiple linear correlation of non-irrigated a rea is shown in Equation 5; together these variables explain $96 \%$ of the WP's behavior in this growing condition $\left(R^{2}=0,96\right)$.

$$
W P=-10,24-0,03 * D N B+0,04 * P E \quad \text { Eq. } 5
$$

Where:

WP: Water use Efficiency $\left(\mathrm{g} \mathrm{m}^{-2} \mathrm{~mm}^{-1}\right)$;

DNB: Defic it during sprouting $(\mathrm{mm})$; $(70 \geq \mathrm{DNB} \leq 400)$;

PE: Effective rainfall (mm); $(600 \geq P E$ $\leq 1000)$.

Equation 5 has been used in STELLA and added as input variables for the model, performing simulations in the software, with real values of water use effic iency.

To simulate the behavior of water use efficiency in relation to changes in air temperature, it was used the study conducted by Machado et al. (2005) (Table 1). These authors obta ined responses curves of $\mathrm{CO}_{2}$ assimilation due to changes in air temperature; the study was conducted in cha mbers with controlled conditions of a ir temperature and different concentrations of $\mathrm{CO}_{2}$. Moreover, the a uthors reported that the limiting factor for photosynthesis exerted by the stomata is equivalent to $23 \%$.

In its struc ture the model comprises adjacent parameters, which are fundamental. The water defic it included to the model was established from the information provided by Marengo (2006), this author has developed a model that simula tes the behavior of ra infa ll until the year 2100, it was made an a nalogy of the future behavior of water defic it, using future scena rios of precipitation provided by the author cited above. In Table 2 a re shown the input data for the simulation of the developed model.

In Table 3 are shown the characteristics of the 9 scena rios for the non-irrigated condition.

Table 1 - Annual $\mathrm{CO}_{2}$ assimilation rate due to air temperature.

\begin{tabular}{lccc}
\hline Temperature $\left({ }^{\circ} \mathrm{C}\right)$ & 25 & 30 & 40 \\
\hline Assimilation percentage (\%) & 81,37 & 93,01 & 59,96 \\
\hline Annual amount of $\mathrm{CO}_{2}$ assimilation $\left(\mathrm{g} \mathrm{m}^{-2}\right.$ year $\left.^{-1}\right)$ & 527,40 & 648,15 & 388,61 \\
\hline
\end{tabular}

Source: adapted from Machado et al. (2005). 
Table 2 - Description of the variables used in the execution of the model - input data.

\begin{tabular}{|c|c|}
\hline Variables & Characteristics \\
\hline $\begin{array}{l}\text { Annual uptake of } \mathrm{CO}_{2} \text { in function of the air } \\
\text { temperature (decimal) }\end{array}$ & $\begin{array}{l}\text { Three temperatures } 25^{\circ} \mathrm{C}, 30^{\circ} \mathrm{C} \text { and } 40^{\circ} \mathrm{C} \text {, } \\
\text { which corresponded, respectively, to } 0,2 ; 0,1 \\
\text { and } 0,4 \text {. }\end{array}$ \\
\hline Rainfall (mm) & $\begin{array}{l}\text { Total average, derived from the data of } 2002 \\
\text { to } 2009 \text {, an amount equal to } 865,00 \mathrm{~mm} \text { and } \\
\text { was assumed behavioral trend established } \\
\text { for Marengo (2006). }\end{array}$ \\
\hline Hydric deficit (mm) & $\begin{array}{l}\text { Total average deficit }(57,76 \mathrm{~mm}) \text {, acquired } \\
\text { by performing the calculation of the water } \\
\text { balance in the period in which the income } \\
\text { was obtained ( } 2002 \text { to } 2009) \text {. To perform the } \\
\text { simulations was adopted initial value in } 2010 \\
\text { equal to } 54 \mathrm{~mm} \text { with a gradual increase to } \\
74 \mathrm{~mm} \text { of water deficit in } 2100 \text {, this variable } \\
\text { was determined from the study of Marengo } \\
\text { (2006). }\end{array}$ \\
\hline Stomatal resistance (decimal) & 0,23 (MACHADO et al., 2005). \\
\hline Canopy volume (decimal) & $\begin{array}{l}1,0 \text { in irrigated condition and 0,59 in non- } \\
\text { irrigated condition (ROMERO et al., 2006). }\end{array}$ \\
\hline $\mathrm{KC}_{\mathrm{Trx}}$ & $\begin{array}{l}\text { Following the recommendations of } \\
\text { Doorenbos and Pruitt }(1977,1984) \text {, we used } \\
\text { the amount equivalent to } 0.85 \text { to } \mathrm{Kc} \text { of the } \\
\text { maximum transpiration }\left(\mathrm{Kc}_{\mathrm{Trx}}\right) \text { during the } \\
\text { phenological cycle of citrus. }\end{array}$ \\
\hline $\mathrm{CO}_{2}(\mathrm{ppm})$ & $\begin{array}{l}\text { Three } \mathrm{CO}_{2} \text { concentrations in the atmosphere } \\
\text { (SUST, MIN and MAX), determined by the } \\
\text { IPCC. }\end{array}$ \\
\hline Inflection point & $\begin{array}{l}600 \text { ppm: reduction of } 50 \% \text { in carboxylation, } \\
\text { parameter set from a review of studies } \\
\text { (PINTO, ASSAD E ZULLO, 2004; STRECK } \\
\text { and ALBERTO, 2006; STRECK, 2005; } \\
\text { MACHADO et al., } 2005 \text { and AMTHOR, 2001). }\end{array}$ \\
\hline
\end{tabular}


Table 3 - Proposed scenarios evaluated in the study

\begin{tabular}{|c|c|}
\hline Scenarios & Description of the scenarios for the non-irrigated condition \\
\hline A & Temperature $25 \circ \mathrm{C}, \mathrm{CO}_{2}$ in sustainable atmosphere $(387-544) \mathrm{ppm}$ \\
\hline B & Temperature $30^{\circ} \mathrm{C}, \mathrm{CO}_{2}$ in sustainable atmosphere $(387-544) \mathrm{ppm}$ \\
\hline C & Temperature $40^{\circ} \mathrm{C}, \mathrm{CO}_{2}$ in sustainable atmosphere $(387-544) \mathrm{ppm}$ \\
\hline D & Temperature $25^{\circ} \mathrm{C}, \mathrm{CO}_{2}$ in maximum atmosphere $(413-1142) \mathrm{ppm}$ \\
\hline E & Temperature $30^{\circ} \mathrm{C}, \mathrm{CO}_{2}$ in maximum atmosphere $(413-1142) \mathrm{ppm}$ \\
\hline $\mathrm{F}$ & Temperature $40^{\circ} \mathrm{C}, \mathrm{CO}_{2}$ in maximum atmosphere $(413-1142) \mathrm{ppm}$ \\
\hline G & Temperature $25 \circ \mathrm{C}, \mathrm{CO}_{2}$ in minimum atmosphere $(413-794) \mathrm{ppm}$ \\
\hline $\mathrm{H}$ & Temperature $30{ }^{\circ} \mathrm{C}, \mathrm{CO}_{2}$ in minimum atmosphere $(413-794) \mathrm{ppm}$ \\
\hline 1 & Temperature $40^{\circ} \mathrm{C}, \mathrm{CO}_{2}$ in minimum atmosphere $(413-794) \mathrm{ppm}$ \\
\hline
\end{tabular}

Results and Discussion

All qua ntities of $\mathrm{CO}_{2}$ in the a tmosphere projected by the IPCC and used in this study, Susta ina ble (SUST), Maximum (MAX) and Minimum (MIN), show an increase in the $\mathrm{CO}_{2}$ concentration in the atmosphere from 2010 to 2100 (SUST, 387-544 ppm; MAX, 413-1142ppm e MíN, 366-794ppm). The results obtained with the simulation of the developed model show an increase in the water use efficiency in the higher $\mathrm{CO}_{2}$ concentrations. Taiz e Zeiger (1991), state that in plants the $\mathrm{CO}_{2}$ is the primary substrate for photosynthesis, e o a umento da concentra ção desse gás na atmosfera ncreasing the concentration of this gas in the atmosphere provides increased growth rate, these authors add that plants with metabolism $\mathrm{C}_{3}$ (citrus) are the most benefited by higher $\mathrm{CO}_{2}$ concentrations (Table 4).
From the results it was observed that the a ir temperature corresponding to $30^{\circ} \mathrm{C}$ determined the highest values of grams of dry matter per $\mathrm{mm}$ of water tra nspired, having $27,69 \mathrm{~g} \mathrm{~m}^{-2} \mathrm{~mm}^{-1}$ at 2100 under the susta inable concentration of $\mathrm{CO}_{2}$ in the atmosphere (scenario $\mathrm{B}$ in Table 4). Similar results were found by Machado et al. (2005) who found that the highest $\mathrm{CO}_{2}$ assimila tion rates in oranges occurbetween 25 and $30^{\circ} \mathrm{C}$ and at air temperatures above $30^{\circ} \mathrm{C}$ there is a reuction in the assimilation of $\mathrm{CO}_{2}$. The results obta ined by these a uthors was critic al to the composition of the scenarios of the present research, because in their study they found that in extreme temperatures, 15 and $40^{\circ} \mathrm{C}$, stomatal conductance is compromised, resulting in a reduction of photosynthetic rate.

Table 4 shows that water use effic iency is higher in scenario $B$, which provided water productivity of $27,69 \mathrm{~g} \mathrm{~m}^{-2} \mathrm{~mm}^{-1}$ in the year 2100 . 


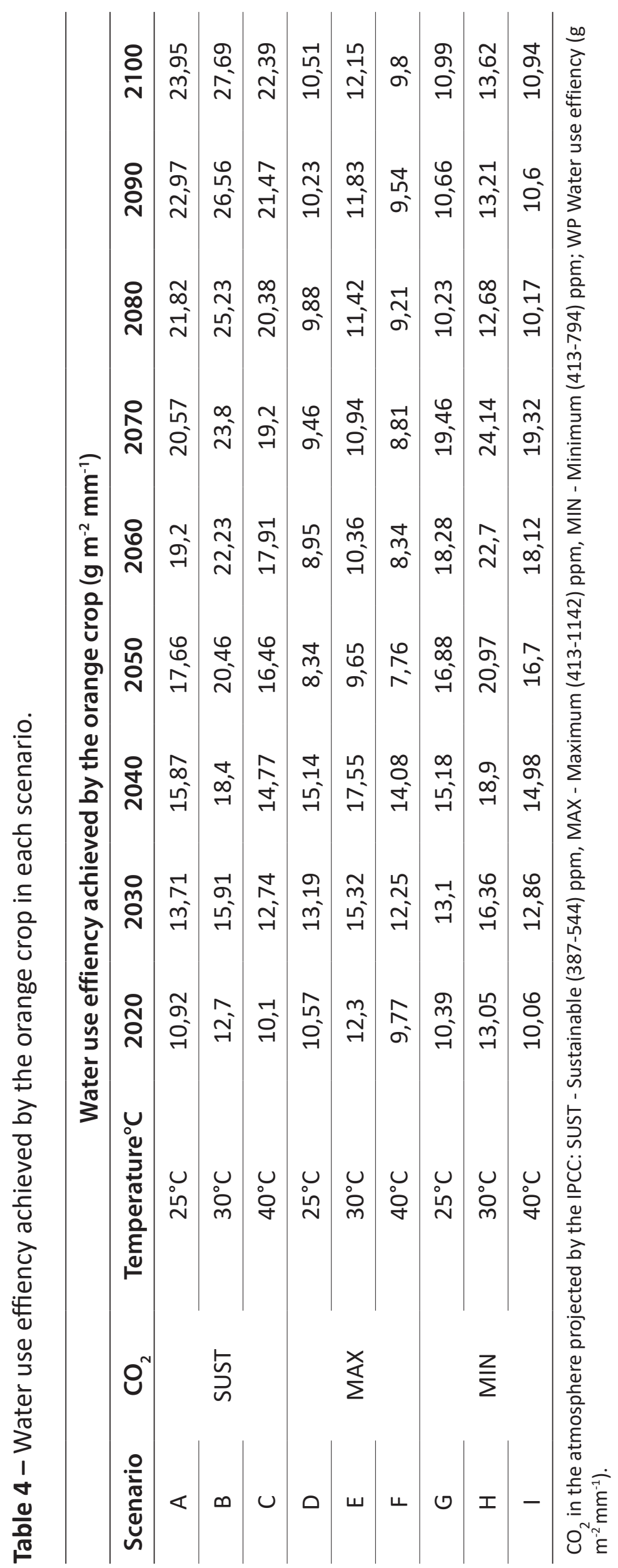


Martinez et al. (2014) performed an experiment with foragers plants subjected to a temperature increase of $2^{\circ} \mathrm{C}$, a lso based on scenarios provided by the IPCC, and found that the increase in temperature by 2050 could benefit the physiology and the biochemical and biophysical processes involved in the growth of these plants. Furthermore, the a uthors found an increase of $32 \%$ in the leaf a rea index and $16 \%$ in the production of above-ground biomass compared to the plants cultivated in normal conditions. The model for the simulation of the orange growth, developed in the present study, predicts an increase in the water use effic iency primarily due to increased biomass production, until atmospheric temperature equal to $30^{\circ} \mathrm{C}$ and $\mathrm{CO}_{2}$ concentration not exceeding 600 ppm.

According Taiz and Zeiger (2004), if the increase in $\mathrm{CO}_{2}$ concentration is followed by an increase in a ir temperature, there can be no increase in growth and crop yields. The works of Allen e Vu (2009); Idso, Kimbal, (1991); Ribeiro e Machado, (2007); Ribeiro et al. (2009); Magalhães Filho et al. (2009) present justific a tions that the increase in $\mathrm{CO}_{2}$ concentrations in the a tmosphere may bring harmful responses in the productivity of citrus.

Other studies using modeling to predict the impact of climate change on agricultural income also demonstra te that for high levels of $\mathrm{CO}_{2}$ in the atmosphere due to the simulta neous increase in temperature can cause a decrease on the agricultural production (KRISHNAN et al., 2007). the a uthors found, according to their model simulations, a reduction of $56 \%$ in rice production, if the $\mathrm{CO}_{2}$ concentration is equal to 700ppm and the a ir temperature inc rea ses $4^{\circ} \mathrm{C}$.

The simulation results for future years (2020 to 2100) show an increase in the amount of biomass of orange per $\mathrm{mm}$ of water transpired with the increase of $\mathrm{CO}_{2}$ in the atmosphere. In fact this is the main result achieved by the developed model, however, in previously published work by Medina, Machado e Pinto (1998), Medina, Machado e Gomes (1999), Medina et al. (2002) e Machado et al. (2005), the authors state that if the increase in $\mathrm{CO}_{2}$ concentrations occur a long with the increase in the vaporpressure defic it, both transpiration rate and $\mathrm{CO}_{2}$ assimilation will be adversely affected, diminuind o o c rescimento das plantas e, portanto, o parâmetro produtividade da água.

\section{Conclusions}

The model represented the processes involved in the water use efficiency by orange under climate changes. At $\mathrm{CO}_{2}$ concentration equivalent to $600 \mathrm{ppm}$ and a tmospheric temperature of $30^{\circ} \mathrm{C}$ the biomass formation will be benefited, but the biomass formation will decrease in higher temperatures and carbon dioxide concentrations.

The increase in $\mathrm{CO}_{2}$ concentrations in the atmosphere positively influences the assimilation and, therefore, increases the biomass production $\mathrm{g}$ per mm of water transpired, however, this beneficial effect may be masked by other effects of that elevation, related mainly to a ir temperature and vapor pressure deficit. 


\section{References}

ALLEN, L.H. and VU, J.C.V., 2009. Carbon dioxide and high temperature effects on growth of young orange trees in a humid, subtropical environment. Agricultural and Forest Meteorology, Amsterdam, vol. 149, no. 5, pp. 820-830.

AMTHOR, J.S., 2001. Effects of atmospheric $\mathrm{CO}_{2}$ concentration on wheat yield: review of results from experiments using various approaches to control $\mathrm{CO}_{2}$ concentration. Field Crops Research, Amsterdam, vol. 73, pp. 1-34.

DELGADO, A.R.S. et al., 2010. Modelagem matemática para otimização da produção e renda de melão e melancia em função de lâminas de água e doses de nitrogênio. Irriga, Botucatu, vol. 15, no. 1, pp. 1-9.

DOORENBOS, I. and KASSAN, A.H., 1979. Yield response to water. Roma: FAO. 193 p. (FAO. Irrigation Drainage Paper, 33).

DOORENBOS, I. and PRUITT, W.O., 1977. LaS necessidades de agua de los cultivos. Estudio FAO Riego y Drenaje, Roma, n. 24. 144p. (FAO. Botelin Irrigation y Drenaje, 24).

DOORENBOS, J. and PRUITT, W.O., 1984. Guidelines for predicting crop water requirements. Rome: FAO.

GRAÇA, J. et al., 2001. Porta-enxertos para laranja 'Natal' no norte fluminense. Laranja, Cordeirópolis, vol. 22, no. 2, pp. 449-456.

IDSO, S.B. and KIMBALL, B.A., 1991. Downward Regulation of Photosynthesis and Growth at High $\mathrm{CO}_{2}$ levels. No Evidence for Either Phenomenon in Three-Year Study of Sour Orange Trees. Plant Physiology, Rockville, vol. 96, pp. 990-992.

INTERGOVERNMENTAL PANEL ON CLIMATE CHANGESIPCC, 2014. Climate Change 2014: Synthesis Report. Contribution of Working Groups I, II and III to the Fifth Assessment Report of the Intergovernmental Panel on Climate Change [CORE WRITING TEAM, R.K. PACHAURI AND L.A. MEYER (Ed.)]. IPCC, Geneva, Switzerland, 151 p. Available in: <http://www.ipcc.ch/ pdf/assessment-report/ar5/syr/SYR_AR5_FINAL_full. pdf>. Access: Out. 2015.

LEDO, A.S. et al., 1999. Porta-enxertos para laranjeirasdoces (Citrus sinenses ( L .) OSB .), em Rio Branco, Acre. Pesquisa Agropecuária Brasileira, Brasília, vol. 34, no. 7, pp. 1211-1216.
LEVY, Y., BIELORAI, H. and SHALHEVET, J., 1978. Long-term effects of different irrigation regimes on grapefruit tree development and yield. Journal of the American Society for Horticultural Science, Alexandria, vol. 103, no. 5, pp. 680-3.

KRISHNAN, P. et al., 2007. Impact of elevated $\mathrm{CO}_{2}$ and temperature on rice yield and methods of adaptation as elevated by crop simulation studies. Agriculture Ecosystems \& Environment, Amsterdam, vol. 122, pp. 233-242.

MACHADO, E.C. et al., 2005. Respostas da fotossíntese de três espécies de citros a fatores ambientais. Pesquisa Agropecuária Brasileira, Brasília, vol. 40, pp. 1161-1170.

MAGALHÃES FILHO, et al., 2009. Variação da temperatura do substrato e fotossíntese em mudas de laranjeira 'Valência'. Pesquisa Agropecuária Brasileira, Brasília, vol. 44, no. 9, pp.1118-1126.

MARENGO, J.A., 2006. Mudanças climáticas globais e seus efeitos sobre a biodiversidade - caracterização do clima atual e definição das alterações climáticas para o território brasileiro ao longo do século XXI. 2. ed. Brasília: Ministério do Meio Ambiente, vol. 1 , pp. 214.

MARTINEZ et al., 2014. Moderate warming increases PSII performance,antioxidant scavenging systems and biomass production in Stylosanthes capitata Vogel. Environmental and Experimental Botany, Amsterdam, vol. 102, pp. 58-67.

MATTOS JUNIOR, D. et al., 2003. Nutrient content of biomass components of Hamlin sweet orange trees. Scientia Agrícola, Piracicaba, vol. 60, pp. 155-160.

MEDINA, C.L., MACHADO, E.C. and PINTO, J.M., 1998. Fotossíntese de laranjeira 'Valência' enxertada sobre quatro porta-enxertos e submetida à deficiência hídrica. Bragantia, Campinas, vol. 57, pp. 1-14.

MEDINA, C.L., MACHADO, E.C. and GOMES, M.M.A., 1999. Condutância estomática, transpiração e fotossíntese em laranjeira 'Valência' sob deficiência hídrica. Revista Brasileira de Fisiologia Vegetal, Londrina, vol. 11, no. 1, pp. 29-34.

MEDINA, C.L. et al., 2002. Photosynthetic response of citrus grown under reflective aluminized polypropylene shading nets. Scientia Horticulturae, Amsterdam, vol. 96, pp. 115-125. 
QUAGGIO, J.A. et al., 2004. Sweet orange trees grafted on selected rootstocks fertilized with nitrogen, phosphorus and potassium. Pesquisa Agropecuária Brasileira, Brasília, vol. 39, no. 1, pp. 55-60.

PEREIRA; SÁNCHEZ-ROMÁN and ORELLANA GONZÁLEZ, 2017. Simulation model of the growth of sweet Orange (Citrus sinensis L. Osbeck) cv. Natal in response to climate change, Climate change, New Jersey, vol. 42, No. 3-4, 2017.

PINTO, H.S., ASSAD, E.D. and ZULLO JR, J., 2004. O aquecimento global e a agricultura. Revista Saneas, São Paulo, vol. 18, pp. 34-37.

RAES, D. et al., 2012. Calculation procedures. In: FAO. AquaCrop. Version 4.0. Roma. Chap. 3

RAES, D. et al., 2009. AquaCrop: The FAO crop model to simulate yield response to water. In: FAO. AquaCrop. Version 4.0. Roma. Chap. 1.

RIBEIRO, R.V. and MACHADO, E.C., 2007. Some aspects of citrus ecophysiology in subtropical climates: revisiting photosynthesis under natural conditions. Brazilian Journal of Plant Physiology, Campinas, vol. 19, pp. 393-411.

RIBEIRO, R.V., MACHADO, E.C. and OLIVEIRA, R.F., 2004. Growth- and leaf-temperature effects on photosynthesis of sweet orange seedlings infected with Xylella fastidiosa. Plant Pathology, Chichester, vol. 53, pp. 334-340.

RIBEIRO, R.V.et al., 2009. Seasonal and diurnal changes in photosynthetic limitation of young sweet orange trees. Environmental and Experimental Botany, Amsterdam, vol. 66, pp.203-211.

ROMERO, P. et al., 2006. Deficit irrigation and rootstock : their effects on water relations, vegetative development, yield, fruit quality and mineral nutrition of Clemenules mandarin. Tree physiology, Oxford, vol. 26, pp. 1537-1548.

SIQUEIRA, O.J.W., STEINMETZ, S. and SALLES, L.A.B., 2001. Efeitos potenciais das mudanças climáticas na agricultura brasileira e estratégias adaptativas para algumas culturas. In: LIMA, M.A.; CABRAL, O.M.R.; MIGUEZ, J.D.G. Mudanças climáticas globais e a agropecuária brasileira. Jaguariúna: Embrapa Meio Ambiente. pp. 33-63.
STEDUTO, P., HSIAO, T.C. and FERERES, E., 2007. On the conservative behavior of biomass water productivity. Irrigation Science, Heidelberg, vol. 25, no. 3, pp. 189-207.

STEDUTO, P. et al., 2009. AquaCrop - The FAO Crop Model to Simulate Yield Response to Water: I. Concepts and Underlying Principles. Agronomy Journal, Madison, vol. 101, no. 3, pp. 426.

STELLA, 2001. Introduction to systems thinking. $\mathrm{NH}$ : High Performance Systems, 165p

STICH, S. et al., 2008. Evaluation of the terrestrial carbon cycle future plant geograph and climatecarbon cycle feedbacks using Five Dynamics Global Vegetation Models (DGVMs), Global Change Biology, vol. 14, no. 9, pp. 1-25.

STRECK, N.A., 2005. Climate change and agroecosystems: the effect of elevated atmosferic $\mathrm{CO}_{2}$ and temperature on crop growth, development, and yield. Ciência Rural, Santa Maria, vol. 35, pp.734-744.

STRECK, N.A. and ALBERTO, C.M., 2006. Estudo numérico do impacto da mudança climática sobre o rendimento de trigo, soja e milho. Pesquisa Agropecuária Brasileira, Brasília, vol. 41, no. 9, pp. 1351-1359.

STUCHI, E.S. and DONADIO, L.C., 2000. Laranjeira folha murcha. Jaboticabal: Funep.

TAIZ, L. and ZEIGER, E., 2004. Fisiologia vegetal. 3.ed. Porto Alegre: Artemed, 719p.

TAIZ, L. and ZEIGER, E., 1991. Plant physiology. Redwood City: Benjamin/ Cummings Pub. Co., 559p. 


\section{Diversity of the \\ Zooplankton (Alpha and Beta) in the Lentic \\ Environment in the Miranda River Basin (MS, Brazil)}

Silva, W.M. ${ }^{1}$, Zanata, L.H. ${ }^{1}$, Roche, K.F. ${ }^{2}$, Silva, T.H.P.N. ${ }^{3}$, So uza, J..$^{3}$, Severino, L.V. ${ }^{4}$, Dua rte, J .D. ${ }^{4}$, Orika ssa, T.N. ${ }^{4}$

'Universida de Federal de Mato Grosso do Sul - Campus Pantanal, Corumbá, MS, Brazil. 2Universida de Federal de Mato Grosso do Sul - FAENG, Campo Grande, MS, Brazil. ${ }^{3}$ Curso de Pós-Graduação em Tecnologias Ambienta is - FAENG, Campo Grande, MS, Brazil.

${ }^{4}$ Curso de Pós-Graduação em Biologia Animal - CCBS, Campo Grande, MS, Brazil. Corresponding autor: wmsilvax@ig.com.br

\section{Abstract}

The zooplankton is one the ma in components of the freshwater environments, and play fundamental services in a quatic system. The diversity of the zooplankton is central to ma inta in these services and inc rease resilience of the system. The a im of this present work was to obta in the values of alpha-diversity, ecologic al diversity and beta-diversity for zooplankton (Rotifera, Cladocera and Copepoda) in lentic environments with different origins, uses, preservation stages in the Miranda River Basin (MRB), Mato Grosso do Sul State (Brazil). The zooplankton was sampled with a graduated trap and filtering water using a net with $20 \mu \mathrm{m}$ of pore size. After counting, the organism it wasapplied the Whitta ker beta diversity coeffic ient and Shannon-wiener diversity index. The total ric hness for each zooplankton group was 62 for Rotifera, 32 for Copepod and 26 for Cladocera. The MRB has two hotspot with different origin and use, one a urban 
reservoir and another a water outcropping. Cladocera presents a more restricted distribution with highest diversity in the platea u and more homogenous population than Rotifera and Copepoda presented a similar pattem.

Keywords: zooplankton distribution, a qua tic ecology, freshwater dispersion, Pa ragua y River Ba sin.

\section{Introduction}

The zooplankton is one the main components of the freshwater environments, and play fundamental services in aqua tic system. These servic es include the nutrient cycling in water (VANNI, 2002) and the energy tranfer by food chain web (TUNDISI, MATSUMURA-TUNDISI, 2003; DIC KMAN et al. 2008). The diversity of the zooplankton is central to mainta in these servic es and increase resilience of the system (DOWING, LEIBO LD, 2010; AWIT, 2011).

Among the many ways to measure the biological diversity, the ric hness (a Ipha-diversity) a nd ecologic a I diversity (Shannon-Weiner index) are the most used (MATSUMURA-TUNDISI, 1997). Another diversity related to spatial a rea is the Beta-diversity that is the product of Gamma diversity (total species of some a rea) by alpha-diversity (the local number of species) (WITHAKER, 1972). Where, if the environment is composed by many sites with low beta-diversity mea ns there is high simila rity a mong them.

The environment changes promote by c lima te and by human a c tivities impact the freshwater system (PERKINS et al., 2015; WALSH et al. 2016) and the diversity dec reasing resulting in loss of biodiversity and diminishing the ecosystem services. In many freshwater systems surrounded by human activities, the biodiversity dec rease changing the ecological diversity too in general became the environment less heterogenic. According McKnight et al. (2007) the environmental homogenization promoting by huma $n$ activities implies in reduction of beta-diversity.

The aim of this present work was to obta in the values of alpha-diversity, ecologic al diversity and beta-diversity for zooplankton (Rotifera, Cladocera and Copepoda)

in lentic environments with different origins, uses, preservation stages in the Miranda River Basin (MRB), Mato Grosso do Sul Sta te (Brazil).

\section{Material and Methods}

The figure 1 show the Miranda River Basin location and the sample point distributions. It were sampled 24 lentic water bodies, including na tural and a rtific ial ones. In each lake were sampled water for chemical and physical analysis. The zooplankton was sampled with a graduated tra $p$ and filtering water using a net with 20 $\mu \mathrm{m}$ of pore size. The filtered sample was preserved using formaldehyde with $4 \%$ in a polyethylene flask. The identific ation and quantification of zooplankton were done using optical mic roscope and 
stereoscope mic roscope and specialized bibliography. It were apply the Whittaker beta diversity coefficient $(y / a)$, where $Y$ is the gamma diversity (all species in the river basin) and $a$ is the alpha diversity (all local species) and Shannon-wiener diversity index (- $\sum$ pi In pi) where pi is the rela tive density of each species at local. The median $(\tilde{x})$ wascalculated for each group.

\section{Results}

The total ric hness for ea ch zo opla nkton group was 62 for Rotifera, 32 for Copepod and 26 for Cladocera. The Rotifera has recorded in 23 sites, the Copepoda in 22 sites and the Cladocera in 15 sites.

The table 1 shows the values for ric hness, Sha nnon-Weiner Index and $\beta$-diversity for zooplankton groups in each sample point.

The results shows that Rotifera presented 12 sites above the median values for diversity index and 11 for Beta-diversity. Copepoda had the same values 12 sites for diversity index and 11 for Beta-diversity, but with one site less and Cladocera presented 8 and 7 respectively.

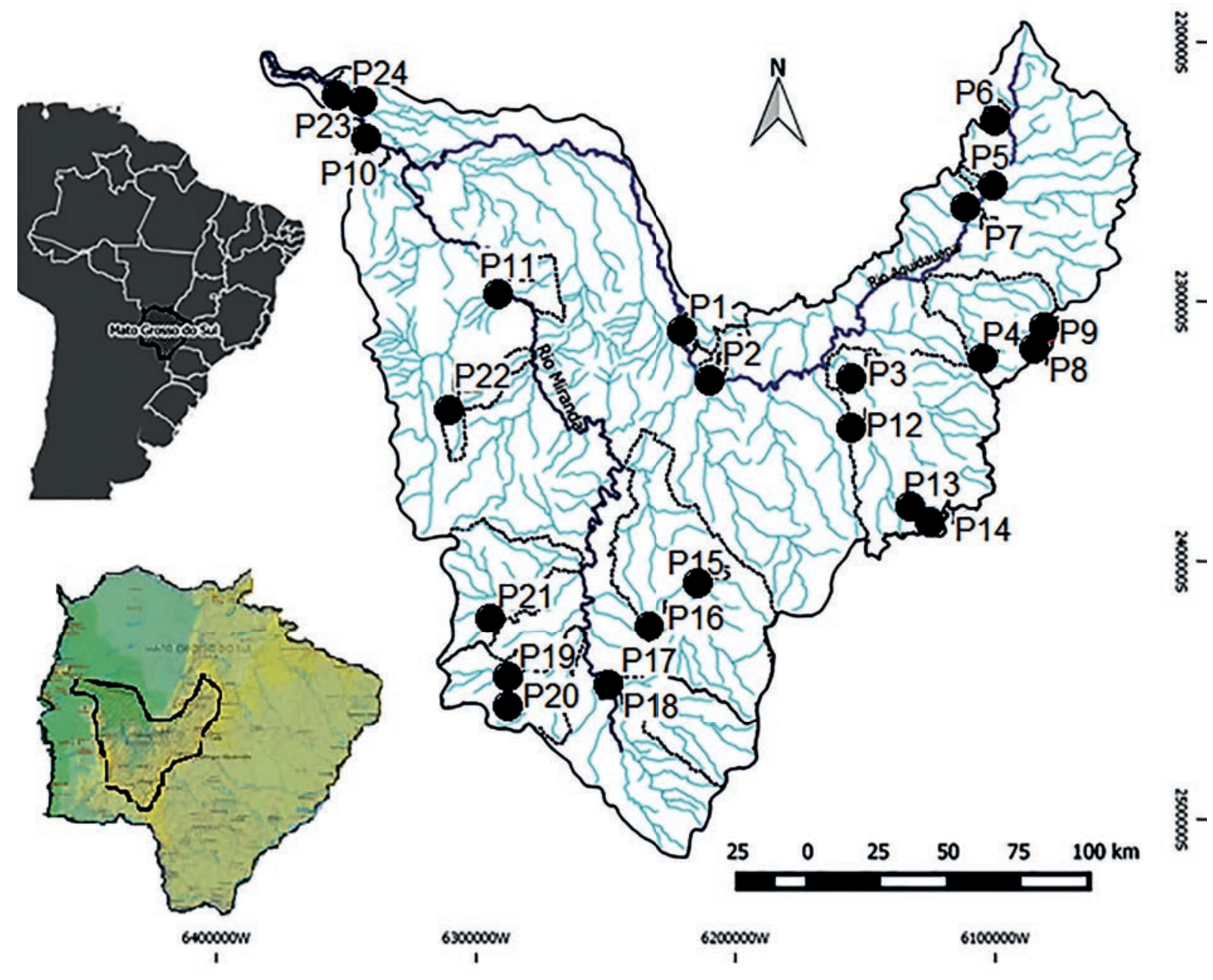

Figure 1 - Location of the Miranda River Basin in the Mato Grosso do Sul State and the samples points distribution. 
Table 1 - The values for richness, Shannon-Weiner index $(H)$ and Beta-diversity $(\beta)$ for Rotifera, Copepoda and Cladocera in the MRB sites and median $(\tilde{x})$.

\begin{tabular}{|c|c|c|c|c|c|c|c|c|c|c|c|}
\hline \multicolumn{4}{|c|}{ Rotifera } & \multicolumn{4}{|c|}{ Copepoda } & \multicolumn{4}{|c|}{ Cladocera } \\
\hline Sites & Richness & $\mathrm{H}$ & $\beta$ & Sites & Richness & $\mathrm{H}$ & $\beta$ & Sites & Richness & $\mathrm{H}$ & $\beta$ \\
\hline P1 & 14 & 2,4 & 4,4 & P1 & 3 & 0,9 & 10,7 & $\mathrm{P} 2$ & 16 & 1,7 & 1,6 \\
\hline P2 & 17 & 2,4 & 3,6 & P2 & 13 & 1,8 & 2,5 & P4 & 6 & 1,6 & 4,3 \\
\hline P3 & 5 & 1,3 & 12,6 & P3 & 4 & 0,6 & 8,0 & P6 & 1 & 0,0 & 26,0 \\
\hline P4 & 12 & 1,5 & 5,2 & P4 & 4 & 0,9 & 8,0 & P11 & 1 & 0,0 & 26,0 \\
\hline P5 & 10 & 1,6 & 6,2 & P5 & 3 & 0,2 & 10,7 & P12 & 5 & 1,3 & 5,2 \\
\hline P5 & 8 & 1,7 & 7,8 & P6 & 4 & 1,3 & 8,0 & P13 & 3 & 0,4 & 8,7 \\
\hline P6 & 14 & 2,5 & 4,4 & P7 & 1 & 0,0 & 32,0 & P14 & 6 & 0,6 & 4,3 \\
\hline P8 & 4 & 1,3 & 15,5 & P9 & 4 & 1,3 & 8,0 & P15 & 3 & 0,5 & 8,7 \\
\hline P9 & 2 & 0,5 & 31,0 & P10 & 1 & 0,0 & 32,0 & P16 & 1 & 0,0 & 26,0 \\
\hline P11 & 3 & 0,6 & 20,7 & P11 & 2 & 0,7 & 16,0 & P17 & 3 & 1,1 & 8,7 \\
\hline P12 & 5 & 1,3 & 12,4 & P13 & 4 & 1,4 & 8,0 & P19 & 5 & 1,3 & 5,2 \\
\hline P13 & 8 & 0,7 & 7,8 & P14 & 2 & 0,5 & 16,0 & P20 & 5 & 0,9 & 5,2 \\
\hline P14 & 9 & 1,4 & 6,9 & P15 & 11 & 1,7 & 2,9 & P21 & 5 & 0,5 & 5,2 \\
\hline P15 & 13 & 0,8 & 4,8 & P16 & 5 & 1,6 & 6,4 & P22 & 4 & 0,9 & 6,5 \\
\hline P16 & 8 & 1,4 & 7,8 & P17 & 3 & 1,1 & 10,7 & P23 & 3 & 0,2 & 8,7 \\
\hline P17 & 10 & 1,6 & 6,2 & P18 & 9 & 1,4 & 3,6 & & & & \\
\hline P18 & 12 & 2,0 & 5,2 & P19 & 3 & 1,1 & 10,7 & & & & \\
\hline P19 & 15 & 2,6 & 4,1 & P20 & 3 & 0,4 & 10,7 & & & & \\
\hline P20 & 6 & 0,4 & 10,3 & P21 & 6 & 0,9 & 5,3 & & & & \\
\hline P21 & 2 & 0,7 & 31,0 & P22 & 2 & 0,7 & 16,0 & & & & \\
\hline P22 & 4 & 1,3 & 15,5 & P23 & 8 & 1,0 & 4,0 & & & & \\
\hline P23 & 10 & 2,0 & 6,2 & P24 & 2 & 0,6 & 16,0 & & & & \\
\hline P24 & 14 & 1,8 & 4,4 & & & & & & & & \\
\hline$\tilde{x}$ & 9,0 & 1,4 & 6,9 & $\tilde{x}$ & 3,5 & 0,9 & 9,3 & $\tilde{x}$ & 4,0 & 0,6 & 6,5 \\
\hline
\end{tabular}

The figure $2 \mathrm{~A}-\mathrm{C}$ shows the loc ation in the MRB of the samples points with high and lowest diversity for the zooplankton group. There were few coincident pointsfor both higher and lower diversity. 
Diversity of the Zooplankton (Alpha and Beta)...
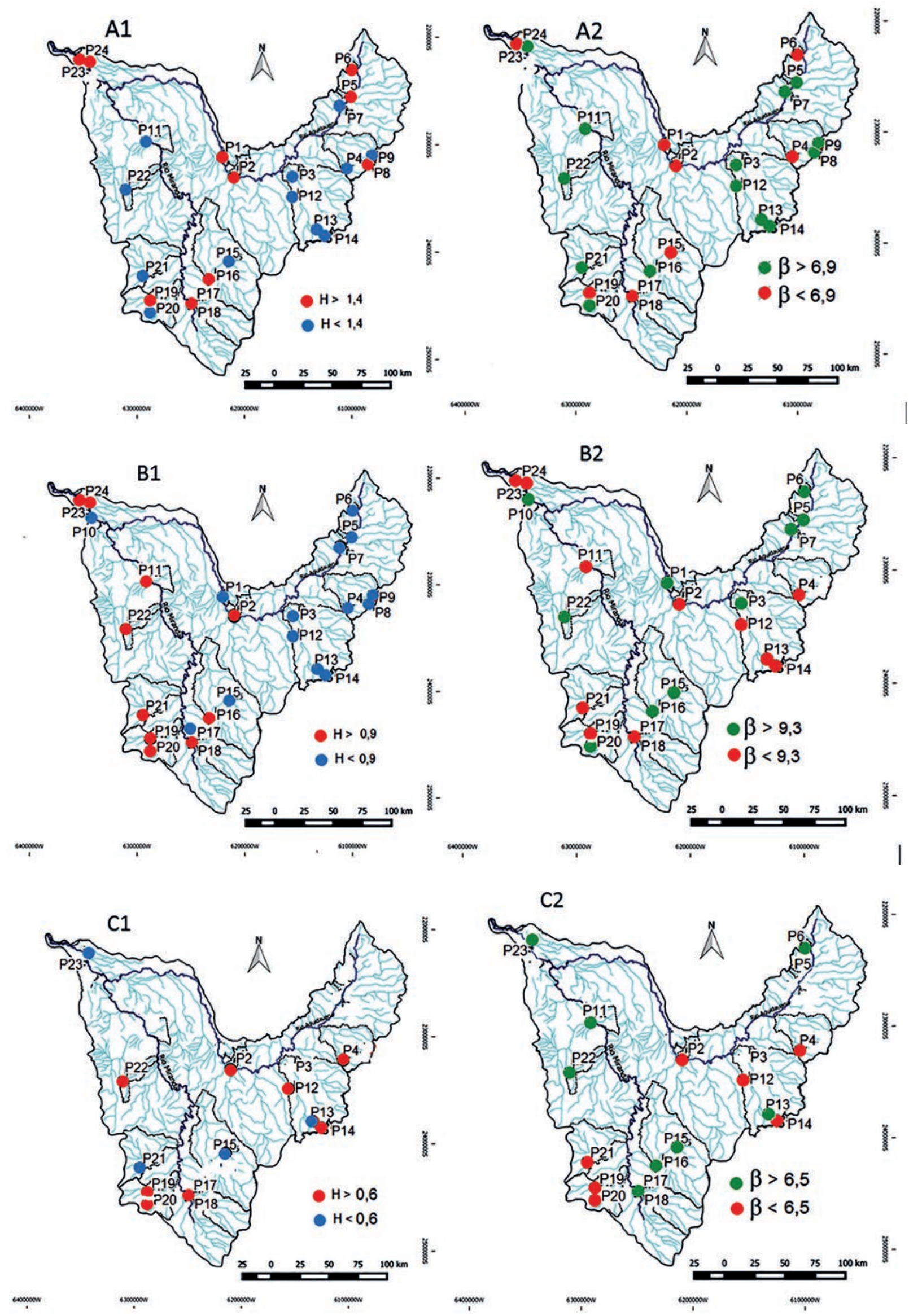

Figure 2 - Distribution of diversity index and beta-diversity for Rotifera $A 1$ and $A 2$; for Copepoda B1 and B2; for Cladocera C1 and C2. 


\section{Discussion}

The distribution of zooplankton has two components by local such as water chemistry and regional factors such as c limate variation (SHURIN et al. 2000). in the RMB the main regional factor is the altimetry degree with high in the east about 250 to $1200 \mathrm{~m}$ and low in the west, Pantanal floodpla in a bout 80 to $150 \mathrm{~m}$ (ALMEIDA et al. 2015).

Rotifera and Copepoda were the most frequent groupsand the Cladocera the less one. The high absence of Cladocera show the na rrow ecological when compared with the Rotifera and Copepoda as observed in other studies of distrib ution (PANARELLI et al. 2013; PINEL-ALOUL, MIMOUNI, 2013). Cladoceran was not retricted to a region but has presented minor frequency in floodpla in area, which is driven by high water fluctuation (ROSSA et al. 2001; PANARELLI et al. 2013; KARPOWICZ, 2016).

Diversity index highest values for Rotifera, Cladocera and Copepoda show some overlap, and point to the hotspot that support high diversity for all groups. Points 2 and 19 are the hotspot. The point 2 is an urban reservoir and 19 is a water outcropping in a cattle farm. These agree with the environmental heterogeneity promotes the diversity in zooplankton communities (COTIENIE, DE MEESTER, 2004; BARNEIT, BEISNER, 2007). Both Rotifera and Copepoda hasa hotspot too in the Pantanal a rea, points 23 and 24, and Cladocera not, with a greementof the hypothesis that this group are most susceptible to wa ter level va ria tion (ROSSA et a I. 2001; PANARELLI et al. 2013; KARPOWICZ, 2016).

Beta-Diversity used be high when the diversity index is low, but some incongruence can be found. The Cladoceran presented a high congruence between both diversities and Rotifera and Cladocera less congruence. Cladocera population is more homogenous (shares more species) in the water bodies, and Rotifera and Copepoda more heterogeneous. The Cladocera presents more restricted environmets and probably is more sensitive to environmental changes (SHURIN et al. 2010), once that population is more homogenous. Most of lakes show a poor combination for diversity had high beta-diversity and low a lpha-diversity (with low diversity index) that is expected (KO LEFF et al. 2003). The small lakes with low diversity index and high beta-diversity valuesare important repository cause has high density that facility the dispersion (DE BIE et al. 2008).

These results combining betadiversity and diversity index drives for two main statements, which works as a tool for environmental managers. The first, Cladocera community shows more sensitive to regional changes, such as plateau and floodplain areas that is in a greement with other distribution studies (SHURIN et al. 2000; NEVALAINEN et al. 2010, SWEETMAN, RÜHLAND 2010). The second, Rotifera and Copepoda communities is determinate by local process, such as pollution and eutrophic ation, these communities histo ric a lly is used for loc al 
water quality indicator (SLÁDEČEK, 1983, MATSUMURA-TUNDISI, 1999, SILVA, 2011, PERBIC HE-NEVES et a I., 2013).

Concluding, the MRB has two hotsp ot with different origin and use, one a urban reservoir and a nothera water outcropping. Cladocera presents a more restricted distribution with highest diversity in the

\section{References}

ALMEIDA, T.I.R., PENATTI, N.C., FERREIRA, L.G., ARANTES, A.E. and DO AMARAL, C.H., 2015. Principal component analysis applied to a time series of MODIS images: the spatio-temporal variability of the Pantanal wetland, Brazil. Wetlands ecology and management, vol. 23, no. 4, pp. 737-748.

AWITI, A., 2011. Biological diversity and resilience: lessons from the recovery of cichlid species in Lake Victoria. Ecology and Society, vol. 16, no. 1. URL: http://www.ecologyandsociety.org/vol16/iss1/art9/

BARNETT, A. and BEISNER, B.E., 2007. Zooplankton biodiversity and lake trophic state: explanations invoking resource abundance and distribution. Ecology, vol. 88, no. 7, pp. 1675-1686.

COTTENIE, K. and DE MEeSTER, L., 2004. Metacommunity structure: synergy of biotic interactions as selective agents and dispersal as fuel. Ecology, vol. 85, no. 1, pp. 114-119.

DE BIE, T., DECLERCK, S., MARTENS, K., DE MEESTER, L. and BRENDONCK, L., 2008. A comparative analysis of cladoceran communities from different water body types: patterns in community composition and diversity. Hydrobiologia, vol. 597, no. 1, pp. 19-27.

DICKMAN, E.M., NEWELL, J.M., GONZÁLEZ, M.J. and VANNI, M.J., 2008, Light, nutrients, and foodchain length constrain planktonic energy transfer efficiency across multiple trophic levels. Proc Nat/ Acad Sci, vol. 105, no. 47, pp. 18408-18412. http:// doi.org/10.1073/pnas.0805566105

DOWNING, A.L. and LEIBOLD, M.A., 2010. Species richness facilitates ecosystem resilience in aquatic food webs. Freshwater Biology, vol. 55, no. 10, pp. 2123-2137. plateau and more homogenous population than Rotifera and Copepoda presented a similar pattern.

\section{Acknowledgement}

We a re thankful to FUNDECT/SUC ITEC/ SEMAC No 09/2012 - BIOTA-MS for their financial support and sc holarship a warded.

KARPOWICZ, M., 2016. Biodiversity of microcrustaceans (Cladocera, Copepoda) in a lowland river ecosystem. Journal of Limnology, vol. 76, no. 1.

KOLEFF, P., GASTON, K.J. and LENNON, J.J., 2003. Measuring beta diversity for presence-absence data. Journal of Animal Ecology, vol. 72, no. 3, pp. 367-382.

MATSUMURA-TUNDISI, T., 1999. Diversidade de zooplâncton em represas do Brasil. In: HENRY, R. Ecologia de reservatórios: estrutura, função e aspectos sociais. Botucatu: Fapesp, Fundibio, cap. 2, p. 39-54.

MCKNIGHT, M.W., WHITE, P.S., MCDONALD, R.I., LAMOREUX, J.F., SECHREST, W., RIDGELY, R.S. and STUART, S.N., 2007. Putting beta-diversity on the map: broad-scale congruence and coincidence in the extremes. PLoS biology, vol. 5, no. 10, p. e272. NEVALAINEN, L., LUOTO, T.P., KULTTI, S. and SARMAJAKORJONEN, K., 2013. Spatio-temporal distribution of sedimentary Cladocera (Crustacea: Branchiopoda) in relation to climate. Journal of Biogeography, vol. 40, no. 8, pp. 1548-1559.

PANARELLI, E.A., GÜNTZEL, A.M. and BORGES, C.N., 2013. How does the Taquari River influence in the cladoceran assemblages in three oxbow lakes? Brazilian Journal of Biology, vol. 73, no. 4, pp. 717-725.

PERBICHE-NEVES, G., FILETO, C., LAÇO-PORTINHO, J., TROGUER, A. and SERAFIM-JÚNIOR, M., 2013. Relations among planktonic rotifers, cyclopoid copepods, and water quality in two Brazilian reservoirs. Latin American Journal of Aquatic Research, vol. 41, no. 1.

PERKINS, D.M., BAILEY, R.A., DOSSENA, M., GAMFELDT, L., REISS, J., TRIMMER, M. and WOODWARD, G., 2015. Higher biodiversity is required to sustain multiple ecosystem processes across temperature regimes. Global change biology, vol. 21, no. 1, pp. 396-406. 
PINEL-ALLOUL, B. and MIMOUNI, E.A., 2013. Are cladoceran diversity and community structure linked to spatial heterogeneity in urban landscapes and pond environments? Hydrobiologia, vol. 715, no. 1, pp. 195-212.

ROSSA, D.C., LANSAC-TÔHA, F.A., BONECKER, C.C. and VELHO, L.F.M., 2001. Abundance of cladocerans in the littoral regions of two environments of the upper Paraná river floodplain, Mato Grosso do Sul, Brazil. Revista Brasileira de Biologia, vol. 61, no. 1, pp. 45-53.

SHURIN, J.B., HAVEL, J.E., LEIBOLD, M.A. and PINELALLOUL, B., 2000. Local and regional zooplankton species richness: a scale-independent test for saturation. Ecology, vol. 81, no. 11, pp. 3062-3073.

SHURIN, J.B., WINDER, M., ADRIAN, R., KELLER, W.B., MATTHEWS, B., PATERSON, A.M. and YAN, N.D., 2010. Environmental stability and lake zooplankton diversity-contrasting effects of chemical and thermal variability. Ecology Letters, vol. 13, no. 4, pp. 453-463.

SILVA, W.M., 2011. Potential use of Cyclopoida (Crustacea, Copepoda) as trophic state indicators in tropical reservoirs. Oecologia Australis, vol. 15, no. 3, pp. 511-521.
SLÁDEČEK, V., 1983. Rotifers as indicators of water quality. Hydrobiologia, vol. 100, no. 1, pp. 169-201.

SWEETMAN, J.N. and RÜHLAND, K.M., 2010. Environmental and spatial factors influencing the distribution of cladocerans in lakes across the central Canadian Arctic treeline region. Journal of Limnology, vol. 69, no. 1, pp. 76-87.

TUNDISI, J.G. and MATSUMURA-TUNDISI, T., 2008. Limnologia. São Paulo: Oficina de Textos, 632 p

VANNI, M.J., 2002. Nutrient cycling by animals in freshwater ecosystems. Annu Rev Ecol Evol Syst., vol. 33, pp. 341-370.

WALSH, J.R., CARPENTER, S.R. and VANDER ZANDEN, M.J., 2016. Invasive species triggers a massive loss of ecosystem services through a trophic cascade. Proceedings of the National Academy of Sciences, vol. 113, no. 15, pp. 4081-4085.

WHITTAKER, R.H., 1972. Evolution and measurement of species diversity. Taxon, pp. 213-251.

WHITTAKER, R.H., 1972. Evolution and measurement of species diversity. Taxon, vol. 21, pp. 213-251 


\section{Impact Assessment of Water Translocation from the Tucutunemo River to Camatagua Reservoir (Aragua State, Venezuela)}

Matos, M.L. ${ }^{1}$, Guajardo, N. ${ }^{1}$

'Universidad Central de Venezuela - UCV y Universidad de los Andes - ULA, Caracas, Venezuela

Corresponding autor: lenymatos@gmail.com, guajardo.nadia@gmail.com

\section{Abstract}

In order to control the increase of water level of Lake of Valencia, during 2009 began the translocation of water from the Taiguaiguay reservoir, through the Tuc utunemo and Guárico rivers, to Camatagua reservoir, which is used as the main source of drinking water for the city of Caracas; this water translocation stopped in J anuary 2015. C onsidering that water of Taigua igua y reservo ir is fed with treated wastewater from Ta iguaiguay treatment plant, which is rich in nutrients, mainly $\mathrm{P}$ and $\mathrm{N}$, the objec tive of this study was to evaluate the impact of water transfer from Taigua iguay reservoir on water quality and quantity of Camatagua reservoir. We a nalyzed the data from 37 sa mples made from 2012 to 2016, near the water intake, in which in situ mea surements and samples were taken for physic ochemic al and biologic al a nalysis (Secchi disk transpa rency, turbidity, a mmonia, phosphates, total dissolved phosphorus, total phosphorus and phytoplankton abundance). Decrease in translocation flow from 2013, until its final elimination in 2015, caused a marked decrease in the water level of $C$ amatagua resenoir. Water transparency and turbidity were affected by the entry of water from the Taiguaiguay reservoir. Also, ammonia and total phosphorus 
concentrations showed an inc rea se from 2012 to 2016, as a consequence of the high content of nutrients reaching to Camatagua reservoir from Taiguaiguay reservoir, as well as the decomposition of the organic matter. Nutrient input stimula ted the increa se of phytoplankton density with dominance of the species Cylind rospermopsis racib orskii, Oscilla toria planctonica, Leptolyng bya limnetica, Mic rocystis a eruginosa and Synechocystis aquatilis for the whole study period.

Keywords: water translocation, ca mata gua reservoir, water quality, eutrophication.

\section{Introduction}

In order to control the water level increase in Lake Valencia, during 2009 the excess of water of Taiguaiguay reservoir was tra sloc ated to the Tuc utunemo River, which joins downstream to the Guá ric o River, the main affluent of the Camatagua resenoir (G ONZÁLEZ et al., 2015). The water from Tuc utunemo River is ric $h$ in nutrients (mostly $\mathrm{N}$ and $\mathrm{P}$ ), which come from the Taiguaigua y treated wastewater treatment plant.

Camatagua is the main drinking water reservoir for the City of Caracas and other adjacent populations (ca. 6 million of inhabitants). The impact of this translocation affected the water quality supplied for human consume, increased the eutrophication process of reservoir

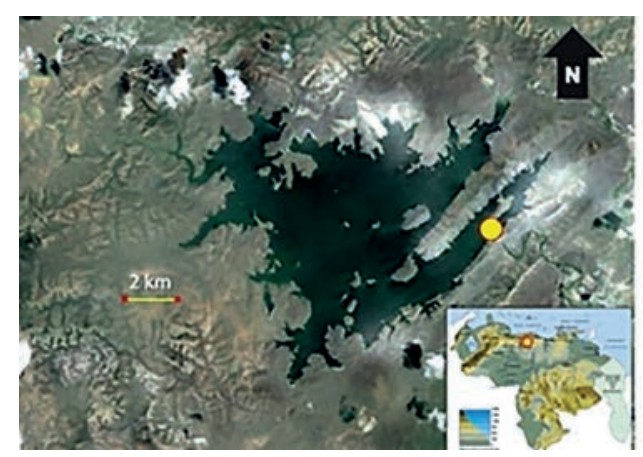

and, by this rea son, it finished in J a nuary 2015.

Camatagua resenoir was classified as eutrophic, according to the criteria of Salas and Martinó (1991) for warm tropical lakes, based on the concentration of total phosphorus (G ONZÁLEZ, 2017).

\section{Objective}

Evaluate the impact of water translocation from Ta iguaiguay reservo ir on the water quality and qua ntity of Camatagua reservoir.

\section{Study Area}

Camatagua reservoir is located in the Central region of Venezuela (Figure 1).

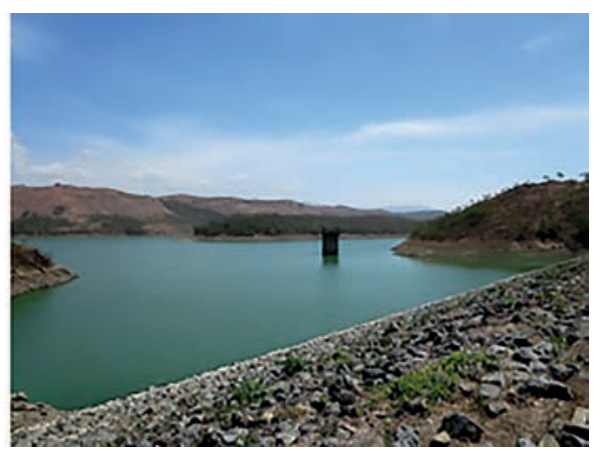

Figure 1 - Relative location of Camatagua reservoir and the sampling site ( ) near the uptake tower. 
Main morphometric

characteristics

of the Camatagua

reservoir

The ma in morphometric characteristics of Camatagua reservoir a re (CASTILLO et al., 1973):

- Geographic location: 950’ N $67^{\circ} 00^{\prime} \mathrm{W}$

- Surface: $59,000,000 \mathrm{~m}^{2}$

- Volume: 1,250,000,000 $\mathrm{m}^{3}$

- Altitude: 302 m.a.s.l.

- Mean depth: $21 \mathrm{~m}$

- Discharge: $19 \mathrm{~m}^{3} / \mathrm{s}$

\section{Methods}

Da ta were analyzed from a total of 37 quarterly sa mples from 2012 to 2016, near the uptake tower in Camatagua reservoir. Samples were taken at the three levels: surface, intermediate and bottom, using a van Dom bottle for physic oc hemic al ana lysis and for phytoplankton in the euphotic layer. In the field, water transparency was measured (Sec chi disk $20 \mathrm{~cm}$ in diameter).

Once in the laboratory, the following variables were a nalyzed:

- Turbidity: Nephelometer HACH.

- Ammonia, phosphates, total dissolved phosphorus and total phosphorus: Standard Methods (APHA, 1992).
- Biological va riables: Phytopla nkton

Samples were fixed with lugol solution. Phytoplankton species were identified after sedimentation in Uthermöhl chambers, observation underan inverted mic roscope and the help of taxonomic al keys for the elaboration of the species inventory. Algal density was determined by counting of c ells in Sedgewick-Rafter and Uthermöhl chambers, with the help of an optical mic rosc ope (APHA, 1992).

Results of all determined variables are shown based on the annual a verage values of the water column. Flow of water transferred from the Ta igua igua y reservoir to the Tuc utunemo River c orresponds to the annual average value.

\section{Results and discussion}

- Translocation diagram from Taiguaiguay reservoir to Camatagua reservoir: During 2009, water translocation from the Taiguaiguay reservoir to the Tuc utunemo River and after to the Camatagua reservoir was made, with an initial flow of $3000 \mathrm{l} / \mathrm{s}$. Figures 2 and 3 show the diagram of water translocation from Taiguaiguay reservoir to Camatagua reservoir. Figure 2 clearly shows clearly the high input of $\mathrm{N}$ and $\mathrm{P}$ to the Guárico River from the Tuc utunemo River. 


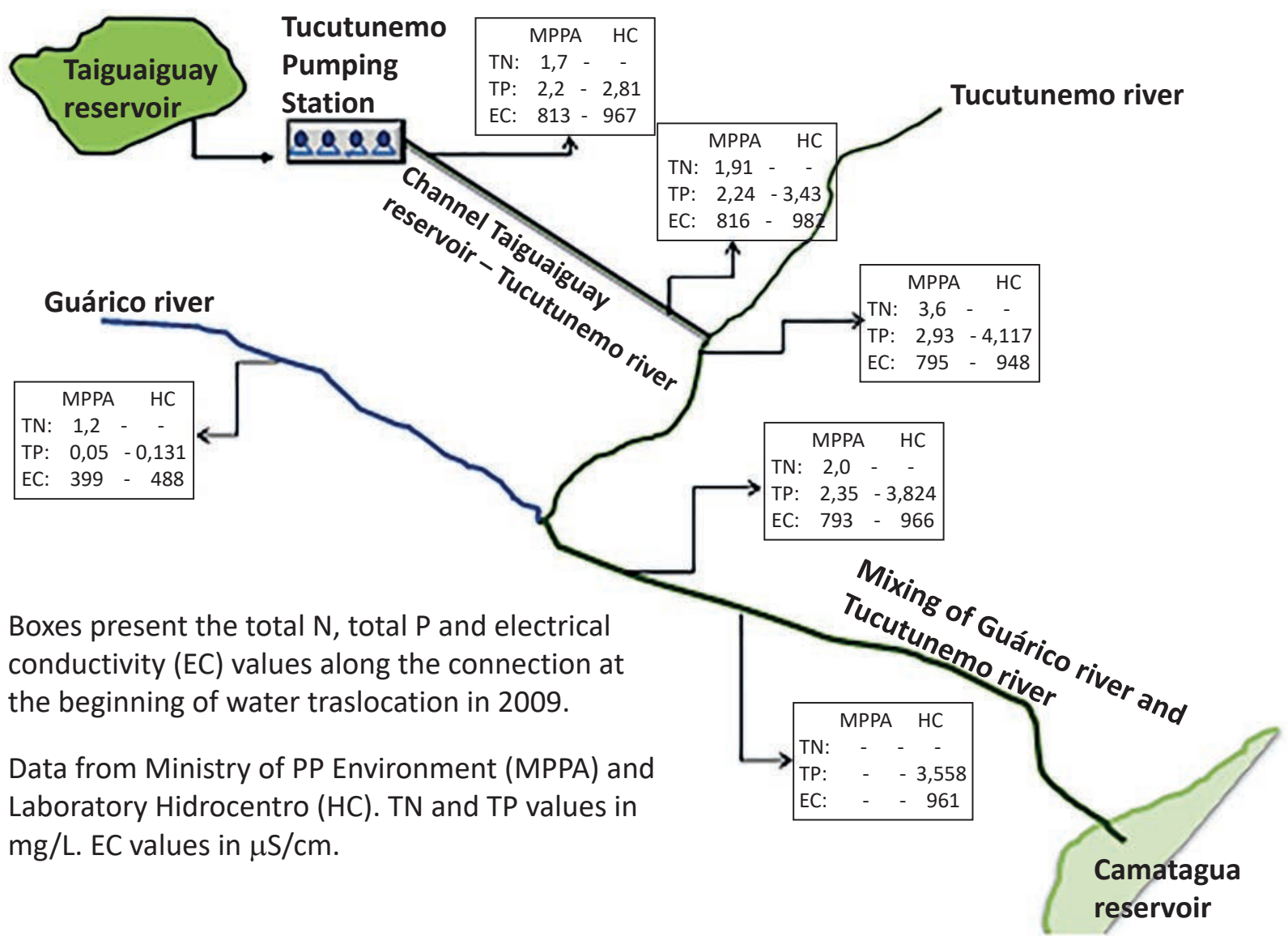

Figure 2 - Diagram of water translocation from Taiguaiguay reservoir to Camatagua reservoir and values of $\mathrm{P}, \mathrm{N}$ and $\mathrm{CE}$ in 2009.

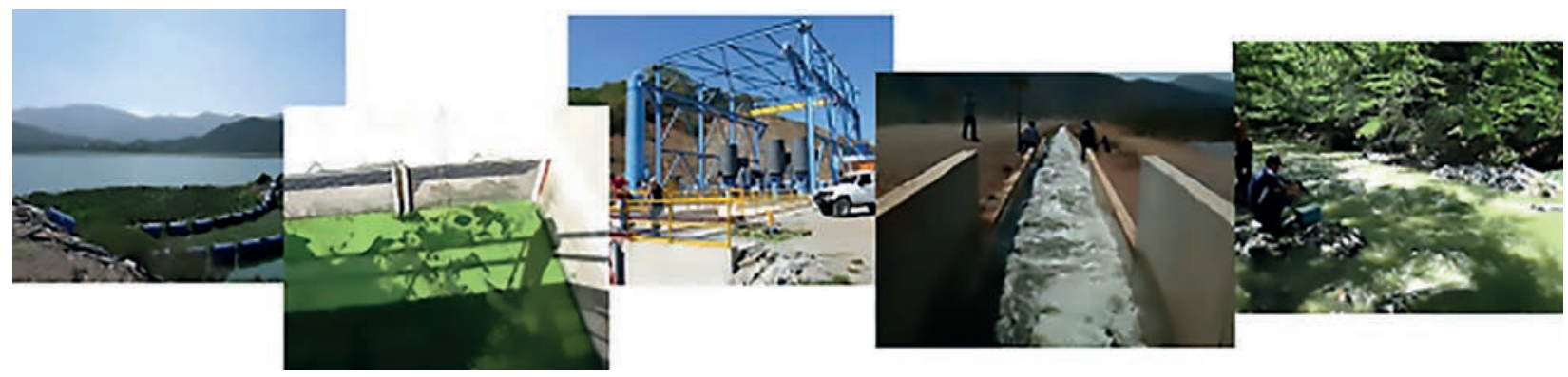

Figure 3 - Flow of translocation from the Taiguaiguay reservoir to the Tucutunemo River. It can be noted the development of a thick layer of phytoplankton in the pit of the pumping station. 
- Translocation and water level in Camatagua resenoir: Water translocation made to control water level of Lake of Valencia, contributed to maintain the nomal level of water in Camatagua reservoir. The decrease in translocation flow from 2013, until its final elimination in 2015, caused a marked decrease in the water level in Camatagua reservoir (Figure 4).

- Transparency and turbidity: Transparency and turbidity (Figure 5) were affected by the entry of water from the Taiguaiguay reservoir. The impact on water qua lity was still present, even after the stop of translocation. As in 2013 , a decrease in water transparency was observed, probably due to the increase in turbidity and the high abundance of phytoplankton, which give the water a turbid greenish color, limiting penetration of light only to a few centimeters from the surface (euphotic layer with no more than $2 \mathrm{~m}$ of extension).

- Ammonia concentration: Ammonia concentration (Figure 6) also showed an increase from 2012 to 2016, as a consequence of the high content of nutrients rea ching the Camatagua reservoir from the Ta iguaiguay reservoir, as well as from the increased organic matter decomposition.

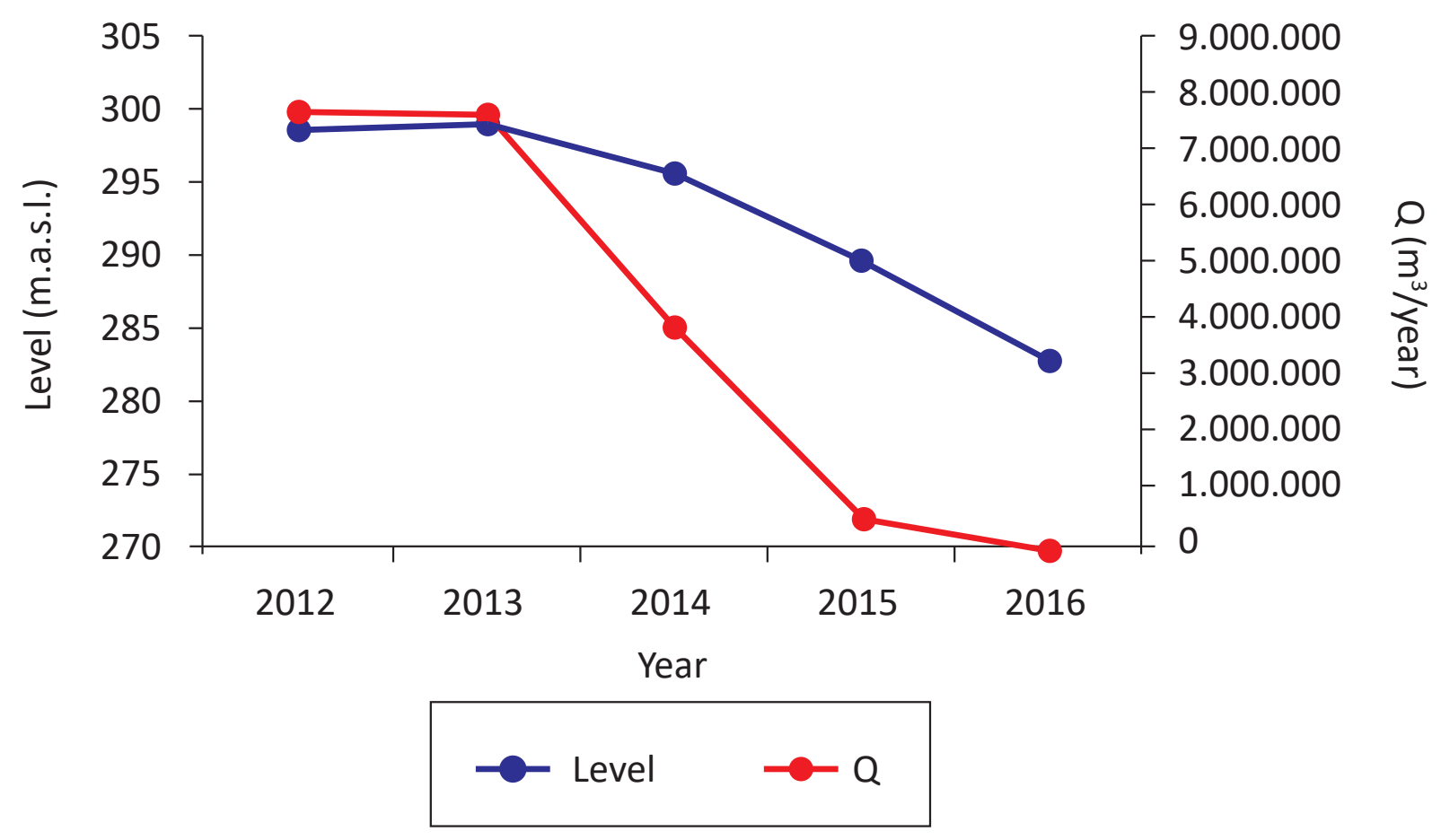

Figure 4 - Relationship between water translocation (Q) and water level in Camatagua reservoir. 

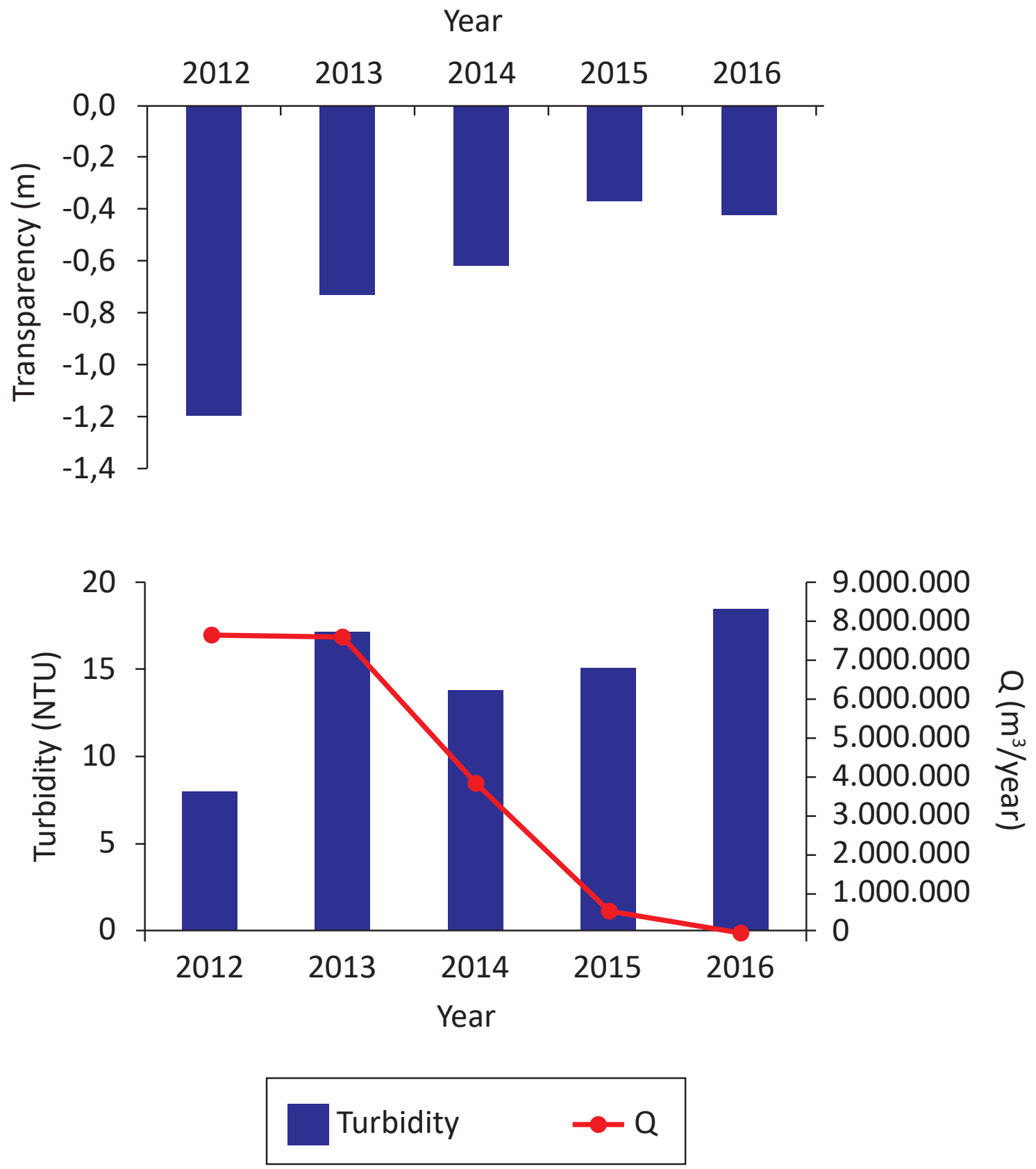

Figure 5 - Relationship between water translocation (Q), transparency and turbidity in Camatagua reservoir. 


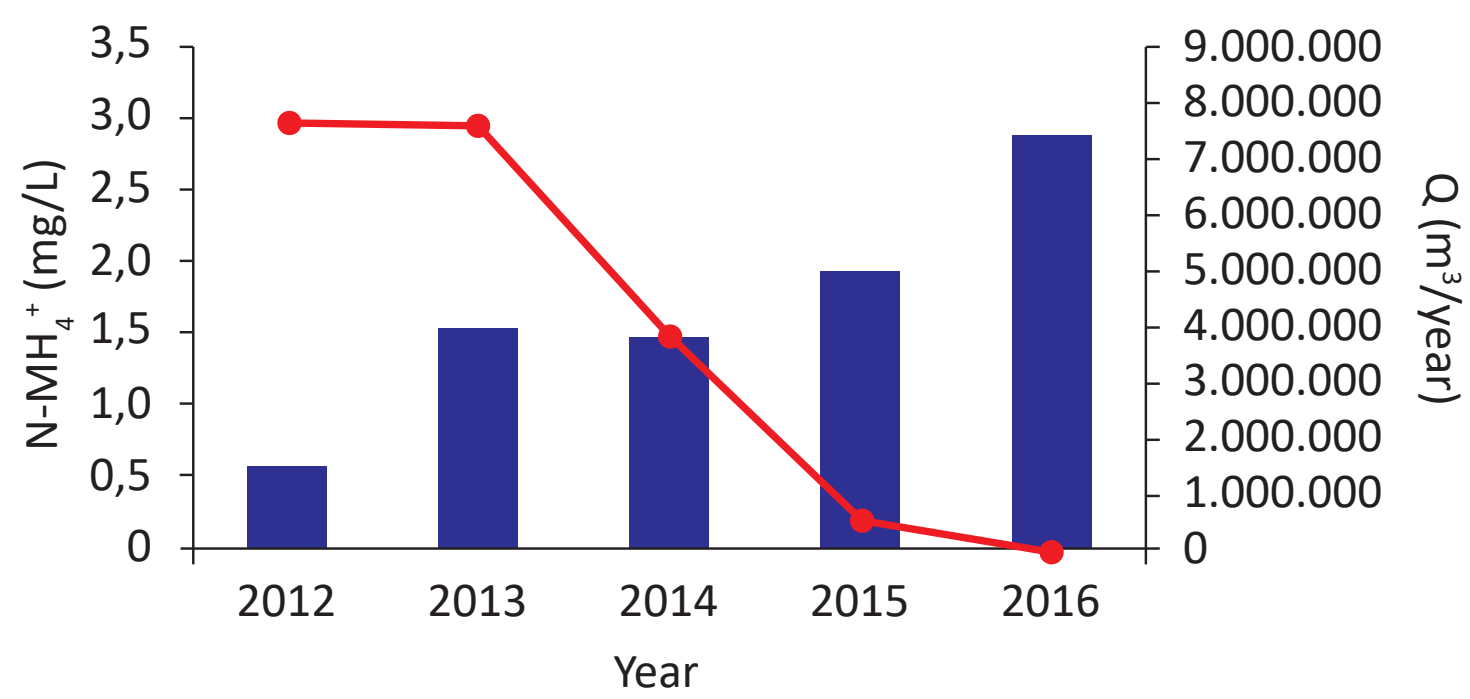

Ammonia $\rightarrow$ Q

Figure 6 - Relationship between water translocation (Q) and ammonia in Camatagua reservoir.

- Orthophosphate, total dissolved phosphorus and total phosphorus concentrations: Ortho phosphate, total dissolved phosphorus and total phosphorus concentration (Figure 7) also showed the same trend of ammonia. According to Salas, Martinó (1991) criteria, this water body was classified as eutrophic. The total-P increased from $40 \mu \mathrm{g} / \mathrm{L}$ in 1992 , to more than $80 \mu \mathrm{g} / \mathrm{L}$ in the euphotic layer (GONZÁLEZ, 2017).
- Phytoplankton: Nutrient input stimulated the increase of phytoplankton density (Figure 8 ) and this community had a change in its composition. Cyanobacteria now accounted up to $90 \%$ of the relative proportion. Cylind rospermopsis raciborskii, Oscillatoria planctonica, Leptolyngbya limnetica, Microcystis aeruginosa and Synechocystis aquatilis were the dominant species during the whole study period. 

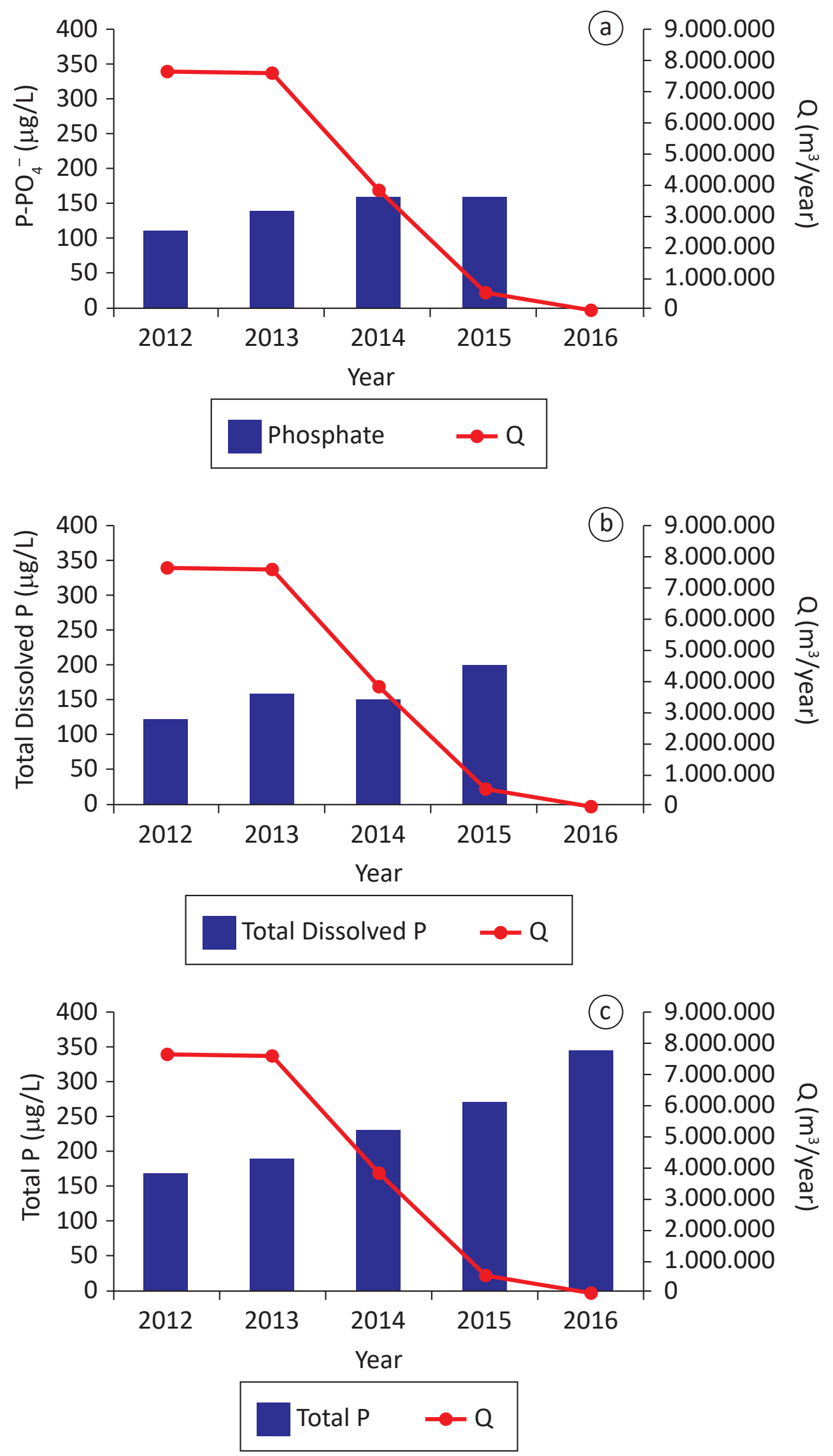

Figure 7 - Relationship between water translocation (Q) and orthophosphate (a), total dissolved phosphorus (b) and total phosphorus (c) in Camatagua reservoir. 


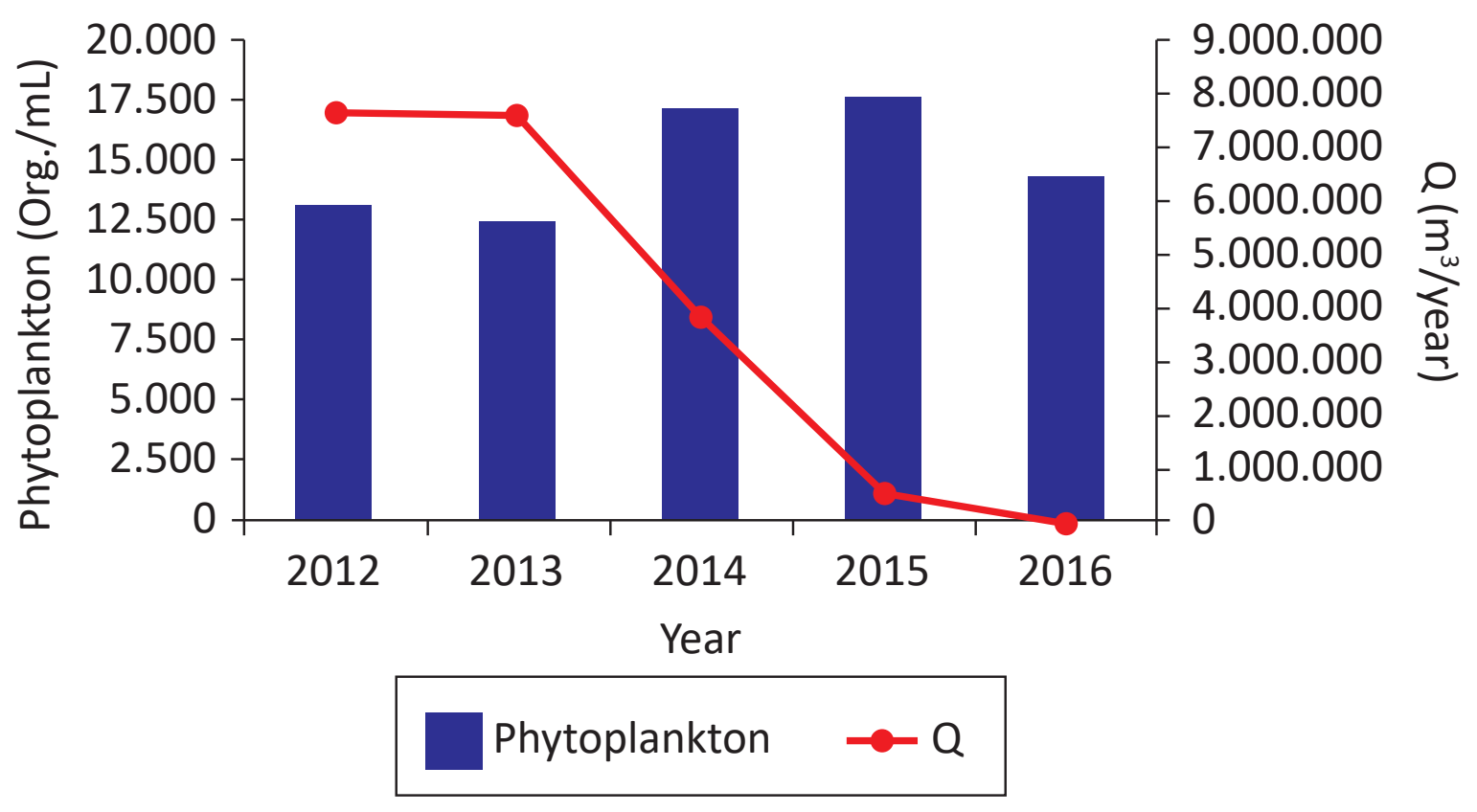

Figure 8 - Relationship between water translocation (Q) and phytoplankton abundance in Camatagua reservoir.

\section{Conclusions}

Water transloc a tion from Ta igua iguay resenoir brought a relative benefit of maintaining the water volume in Camatagua reservoir at normal levels, but affecting its wa ter qua lity.

Despite the reduction of the transloc ation since 2013 until its total elimination in J a nuary 2015, a mmonia, orthophosphate, total dissolved phosphorus and total phosphorus concentrations, continue to increase in Camatagua resenoir, probably due to the decrease of watervolume in Camatagua reservoir that also contributed to the increase of nutrient concentration.

An increase in phytoplankton abundance was also noted, mainly Cya nobacteria species, as a result of the nutrient input from the Taguaiguay reservoir.

Trophic state of Camatagua reservo ir changed from oligo-mesotrophic in 1992, to eutrophic after the water translocation.

\section{Acknowledgements}

Authors wish to thank the hydrological compa nies HIDRO CENTRO, HIDRO C APITAL a nd HIDROVEN, for fina ncial a nd logistic al support. We also thank E. González, who helped in the review of this a rticle. M. L. Matos thanks the São Paulo Research Foundation (FAPESP) and International Institute of Ecology (IIE) for the travel grant to assist to the International Tra ining Course of the São Paulo Advanced School on Integrated Water Resources Management, held in São Carlos, Sã o Paulo Sta te, Brazil, from November $2^{\text {nd }}$ to $17^{\text {th }}, 2017$. 


\section{References}

APHA, 1992. Standard methods for the examination of water and wastewater. 18th. edition. APHA, AWWA, WEF. Washington.

CASTILLO, C.E., GÓMEZ, J. and MONTES, C., 1973.

El Agua. Serie Embalses de Venezuela, vol.1, no. especial. Caracas.

GONZÁLEZ, E.J., 2017. Evaluación limnológica del embalse Camatagua (Edos. Aragua y Guárico). Informe Final del Proyecto PEII 20110001391. FONACIT. Caracas, $37 \mathrm{p}$.
GONZÁLEZ, E.J., MATOS, M.L., BUROZ, E., OCHOAITURBE, J., MACHADO-ALLISON, A., MARTÍNEZ, R. and MONTERO, R., 2015. Urban Water. Venezuela. In: ROLDÁN, G., TORREGROSA, M.L., VAMMEN, K., GONZÁLEZ, E.J., CAMPUZANO, C. and DE LA CRUZ, A. (Eds.). Urban Water Challenges in the Americas. Perspectives from the Academies of Sciences. Inter-American Network of Academies of Sciences (IANAS) - Programa de Aguas, con apoyo de IHPUNESCO. ISBN 978-607-8379-12-5. México: 556-601.

SALAS, H. and MARTINÓ, P., 1991. A simplified phosphorus trophic model state for warm-water tropical lakes. Wat. Res., vol. 25, pp. 341-350. 


\section{Composition of the Characidae Family (Order: Characiformes, Pisces) in an Andean-Amazonian River, Case Study Hacha River Basin (Caquetá-Colombia)}

Remic io-Duque, J .H. ${ }^{1}$, Pela ez-Rodriguez, M. ${ }^{1}$, Gaspar, S. ${ }^{2}$

'Research Group on Quality and Preservation of Aquatic Ecosystems, Facultad de Ciencias Basicas, Universidad de la Amazonia, Florencia (Caquetá) Colombia.

2Ekolur Environmental Consultancy, SLL, 20180 O ia rtzun (G ip uzkoa). Spa in.

Corresponding author: jremicio@uniamazonia.edu.co, mpelaez@unia mazonia.edu.co

\section{Abstract}

An ic hthyologic al inventory of the Characidae family (order: Cha ra ciformes) was ca ried out on a n altitudinal gradient (2112 to 248 m.s.) of an Andean-Amazonian river basin of the Hacha river, located in the municipality of Florencia, department of Caquetá (Colombia). The collections were developed in 10 sampling stations through two fishing gears (electric fishing and traditional fishing); between the months of October to March, in two consecutive years (2009 and 2010), corresponding to the low water period. 459 individuals were collected, identified and grouped into 14 genera and 18 species; the highest abundances corresponded to the species Hemibryc on sp. (151 ind ividuals), Boehlkea cf. fredcochui (88), Creagrutusamoenus (50) and Creagrutusc ochui (35). In conclusion, it can be indic ated that the greatest wealth (12sp.) occurs in the lower basin of the river, it is also noteworthy that the 18 species a re new reports for the Hacha river basin, 12 species for Caquetá and one (1) species for the Colombian Amazon.

Keywords: Characidae, Hacha River, Andean-Amazonian. 


\section{Introduction}

The order Cha raciformes is composed of approximately 1962 species, which correspond to about 34\% of freshwater species in the world (ALBERT et al., 2011), grouped into 274 genera and 18 families (GÉRY, 1977, REIS, KULLANDER 2003, MOYLE, CECH, 2004, NELSON, 2006). By regions, the Amazon basin exhibits the highest ric hness with about 1450 species of fish (GÉRY, 1984), of this number a lmost 50\% a re spec ies of the order Chara c iformes (Nelson, 2006). However, despite the high wealth, there are regions of the basin where the knowledge of this order is meager, such as the Colombian Amazonian Andean region and in particular the case of the river basin of the Hacha River, located in the municipality of Florencia (Caquetá), which supplies drinking water to the municipality (the most populated city of the Colombian Amazon), the Hacha River is the main place of recreation and, a little noble use, as a receiver of the wastewater of the city (PELÁEZ et al., 2006).

The first samplings for the Department of Caquetá were carried out by Brother Nicéforo María on the Ortegüaza Rivera round 1900, the results of which were published by Fowler (1943, 1945). Mojica et al. (2005) and Galviset al. (2007) reported 30 species for the order Characiformescollected in tributa ries of the Caquetá river, a mong them the Ortegüaza river. At the local level, the Universidad of the Amazonia, has c a rried out some works, results of degree projectsand master thesis such as Celis, Ortiz (2003); Rueda, Alma rio (2004); Díaz, Esc obar (2004); Celis (2010); C há ves (2011) and Perdomo et al. (2012). The following is an updated list of the Characidae family (order: Characiformes) of the Hacha River Basin, integrated from the literature review, the biological collection of the Institute of Natural Sciences (ICN) and what was reported in this work.

\section{Materials and methods}

The study wascarried out in the ma in channel of a mounta in river (Hacha) of the Andean-Amazonian region, department of Caquetá (Colombia) between the coordinates $01^{\circ} 52^{\prime} 40,7$ “ N- 75 ${ }^{\circ} 40^{\prime} 44,1$ “W and 133'19,2" N-7531'55 “W. The hydrographic basin covers an area of 490.18 square kilometers and covers a distance of $66.7 \mathrm{~km}$ from its source at 2,400 m. a.s. I. in Cerro Gabinete until its convergence with the Ortegüaza River, at a $n$ altitude of 248 m. a. s. I. (POMCA, 2005) (Figure 1).

The collections were made during two consecutive years, between the months of October to March (low waters) of 2009 and 2010 respectively. These were carried out in 10 sampling stations representa tive of the uses given to the river Hacha (Annex $A$, the list of struc tural cha ra c teristic s of the stations is presented), through two fishing techniques: tra ditional fishing (cast nets and hooks) and electric fishing (LOBÓN-CERVIÁ, 1991; ELOSEGI, SABATER 2009) in order to capture the largest number of specimens present in this ecosystem. The captured specimens were fixed in $10 \%$ formaldehyde, then in 70\% a lc ohol (MOJ IC A et al., 2005; MALDONADO-OCAMPO et al., 2006) and were deposited in the IC N's Ichthyological collection. 


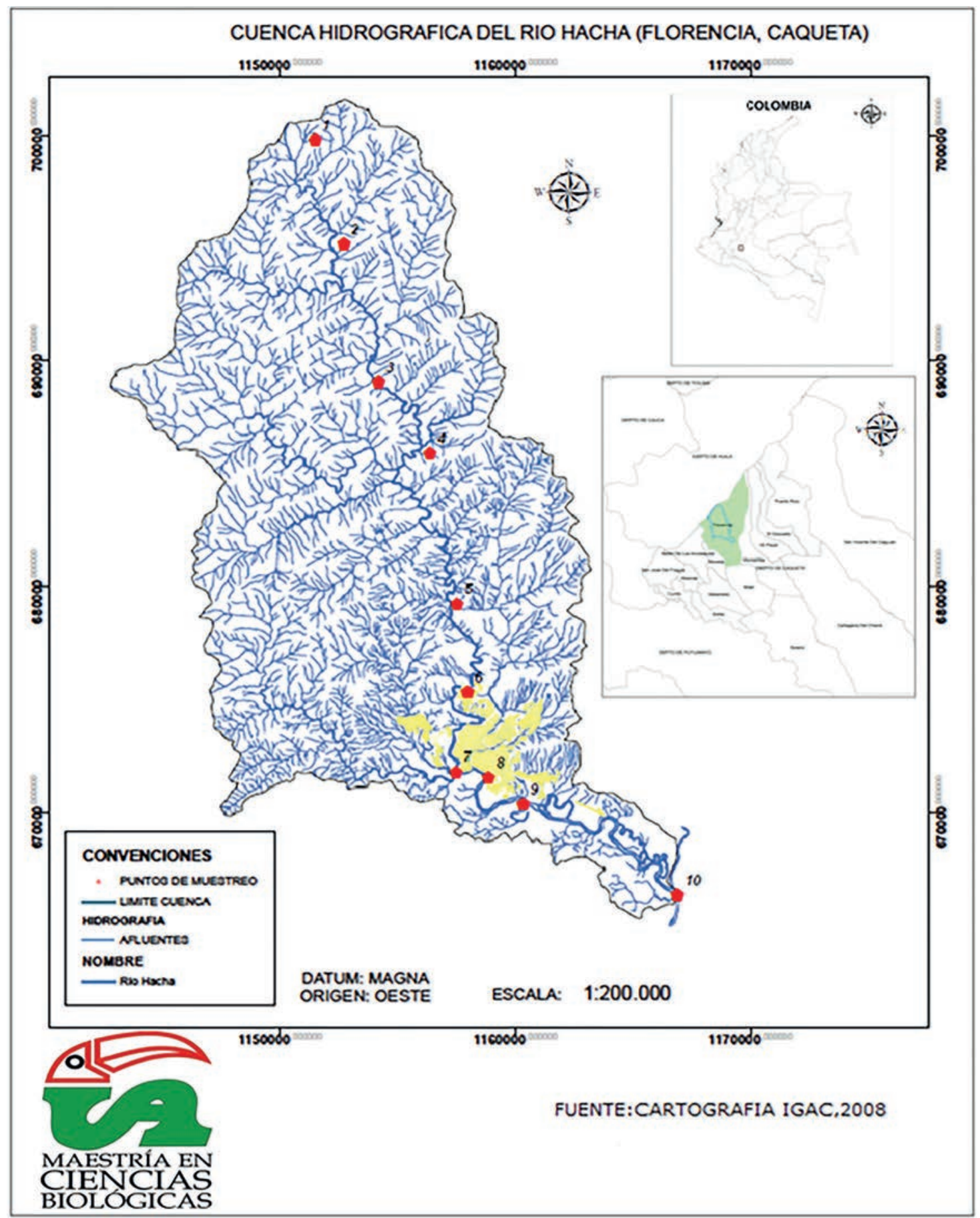

Figure 1 - Geographical location of the study area, municipality Florencia, Caquetá (Colombia).

For the taxonomic determination, we followed Fowler (1943); Fowler (1945); G ÉRY (1977); C a stro (1997); Mojic a (1999); Maldona do et al. (2006); G regory-Mald ona do (2006); Ortega Lara et al. (2006); Galvis et al. (2007);
Rubio (2007) and Román-Valencia et al. (2013). Likewise, ic hthyologic a I materia I deposited in the reference collection of the ICN-MHN of the Universidad Nacional de Colombia and the advice of specia lists wa s c o nsulted. 


\section{Results}

The results obtained are presented through a systematic list of the ic hthyofauna found in the basin of the Hacha river. We collected 459 individuals grouped into 14 genera and 18 species (Appendix B) and Figure 2.
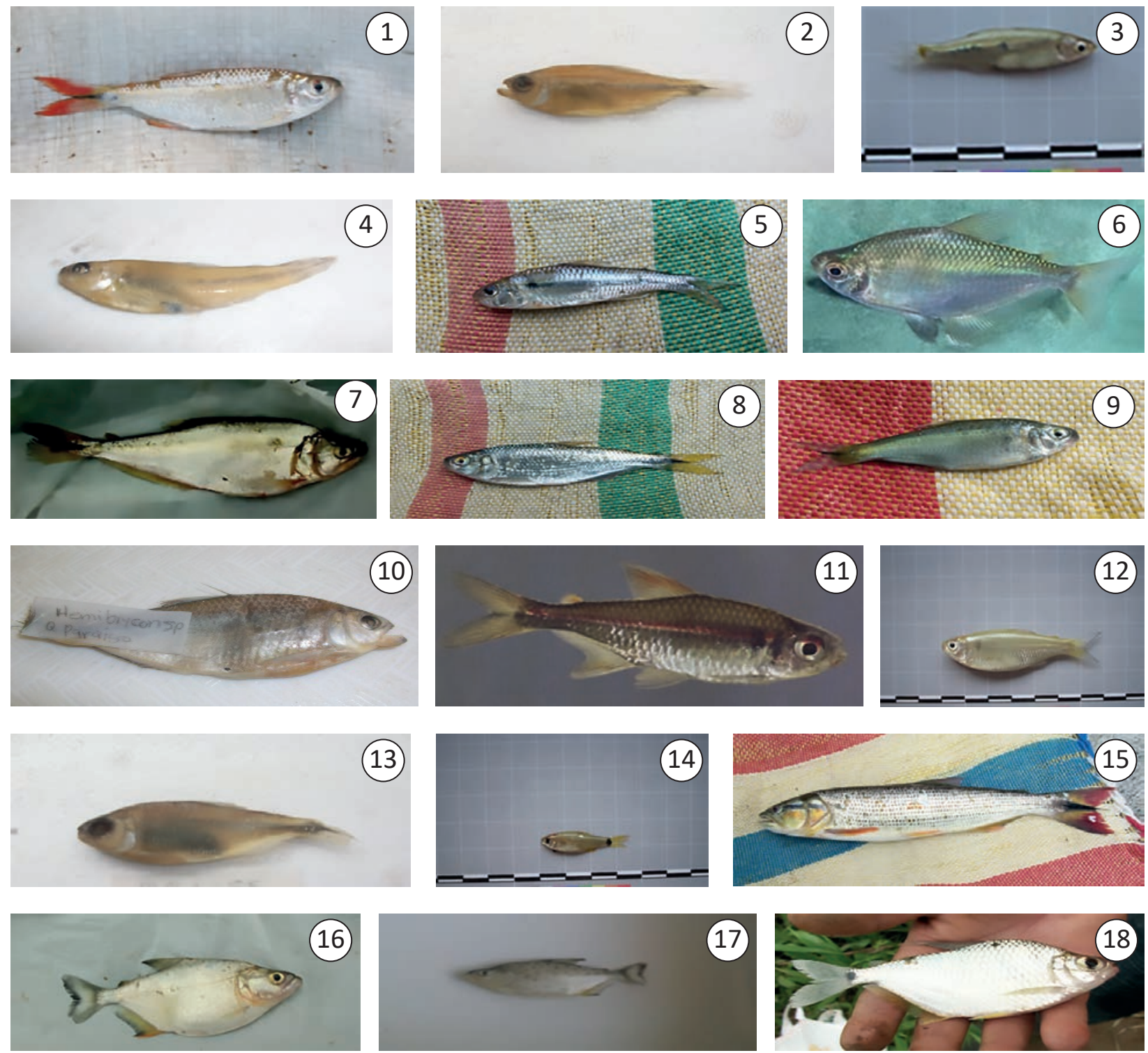

Figure 2 - Species Characidae family 1. Astyanax fasciatus, 2. Astyanax symmetricus, 3. Boehlkea cf. fredcochui. , 4. Creagrutus cf. amoenus, 5. Creagrutuscochui, 6. Ctenobrycon cf. hauxwellianus, 7. Cynopotamusamazonum, 8. Hemybriconsp, 9. Hemibrycon sp2, 10. Hemibrycon sp3, 11. Hyphessobryconsp, 12. Knoduscarlosi, 13. Moenkhausiarobertsi, 14. Odontostilbe cf. caquetae, 15. Salminusaffinis, 16. Pristobryconcalmoni, 17. Serrasalmusrombeus, 18. Tetragonopterus argenteus. 
This list of spec ies inc lud es information on:

- Scientific name: Gender and specific epithet, followed by the a uthor of the description and the year of public ation.

- Species in collection: The number of the file of the deposited species is listed in the Institute of Natural Sciences (INS), Museum of Natural History (MNH), ic hthyology a rea.

- Synonymies: Includes the scientific name, author and year.

- Common name: Reference the regional name of the species.

- Description: Information regarding the pigmentation, morphology, size and morphometry of the species.

- Distribution: It reviews the localities where there are reliable records of the species; they begin with the type loc a lity (altitudinal range in the Hacha river); then, general data of the distribution for Colombia and the Neotropic are referenced, based on the literature review. Also, image of the species is attached.

\section{ORDER CHARACIFORMES: CHARACIDAE FAMILY}

\section{Astyanax fasciatus (CUVIER, 1819).}

Collection number ICN-MHN: 17918.

Synonyms: A. fa sc ia tusortegua sa e (FOWLER, 1943).

Common name: red tail sardine, yellow ta il sardine, tolomba, greedy, old lady (Ven).

Description: Medium-sized fish that reach $17 \mathrm{~cm}$ instandard length (SL), a re silvery color dorsally, cauda I with a well-marked black caudal spot. Some specimens show an intense reddish color in the caudal fin (GALVIS et al., 2007); middle rays of the dark caudal and the other orange with the hya line ends (VARGAS-TISNES, 1989).

Distribution: Located in the stations of the urban area of the city of Florencia between 262-261m. a. s. I.; Fowler (1943, 1945) reported it for the Bodoquero river of Morelia Caquetá; However, in other regions it has a wide distribution as in the Magdalena, Cauca and the Amazon ba sins (FOWLER, 1943; MOJ IC A, 1999; ORTEG A-LARA et al., 2002; G REG ORYMALDONADO, 2006; G a lvis et al., 2007; MALDONADO-OCAMPO et al., 2008; MALABARMA et al., 2003) report ed it from Mexic o to Argentina.

\section{Astyanax symmetric us (EIG ENMANN,} 1908).

\section{Collection number ICN-MHN: 17861.}

Common name: Sardine.

Desc ription: Sma ll fish with SL from 3 to 6 cm, more or less uniform body, terminal mouth. In alcohol it turns brown with a light colored stripe on the ventral side.

Distribution: 262-261 m.a.s.l.; It was loc ated in the stations known as La Floresta and Puente López in the municipality of Florencia (capture method: Electric fishing). Malabarma et al. (2003) reported for the Amazon River basin.

3. Boehlkea cf. fredc oc hui (GÉRY, 1966). Synonymies: Mic robryc onc oc hui (NON LADIG ES, 1950) www.fishba se.org. 
Common name: Little sardine, blue tetra (Per).

Description: Sma ll size fish of 4 to $5 \mathrm{~cm}$ of SL, similar to the Hemibryc on (GÉRY, 1977), irregular lateral line. Its body is met al.lic light blue.

Distribution: 635-262 m.a.s.l.; it was loc ated between the station known as Carañoto the la Floresta station in the city of Florencia (method of capture: electric fishing). Gregory-Maldonado (2006) reported it for the Colombian Amazon.

4. Creagnutusamoenus (FOWLER, 1943). Synonymies: Crea grutusb o ehlkei (GÉRY, 1977).

Common name: Little sa rdine.

Description: Fishes with $\mathrm{SL}$ of $8 \mathrm{~cm}$ are recognized by presenting the maxilla more pronounced than the jaw. They have a gray spot on the dorsal fin and dark patches on the lateral line. The general coloration of the body is silver with reddish overtones and in alcohol presents a clear brown coloration.

Distribution: 635-296 m.a.s.l.; it was collected between the sites known as Paraíso-Carañoto the first bridge (north) of the city of Florencia (capture method: Electric fishing). Fowler (1943) and Galvis et al. (2007) reported it to the Ortegüaza River; Gregory-Maldonado (2006) for the Amazon River basin.

5. Creagrutusc oc hui (GÉRY, 1964).

Collection number ICN-MHN: 17871, 17874, 17887.

821
Common name: Squeaky (Flo rencia), little mojarra, little sardine.

Description: Sma ll spec ies that grows up to $7.9 \mathrm{~cm}$ of SL. With an elongated and cylindric al body, brown with a well-defined horizontal humeral spot and all its fins a re hya line except for the dorsal fin.

Distribution: 890-248 m.a.s.l.; between the sites known as the vereda Sucre to the confluence of the Hacha river with the Orteguaza (methods of capture: traditional fishing and electric fishing). MaldonadoOcampo et al. (2008); Ga lvis et al. (2007); Gregory-Maldonado (2006), reported it in streams of intermediate waters near Leticia.

6. Ctenobryconhauxwellianus (COPE, 1870).

Synonymies: C. spilurusha uxwellia nus, Tetrag ono pterusha uxwellia nus (COPE, 1870).

Common name: Wide sardine (Florence), s. fat, pinky, little mojarra, la mbari (Bra).

Description: Small species that reached $6.5 \mathrm{~cm}$ of SL. Wide body and small sc ales, light brown in the dorsal and silver on the ventral side, with a gray band on the la teral line.

Distribution: 253 - 248 m.a.s.l.; it was located between the Florencia Airport station to the confluence with the Ortegüaza river (capture method: Electric fishing). Galvis et al. (2007); Fowler $(1943,1945)$ reported it for tributa ries of the Caquetá River in the munic ipality of Morelia. It is a lso distributed in the Amazon River basin (MOJ ICA et al. 2005; GREG ORY-MALDONADO 2006; MALDONADO-OCAMPO et al. 2008; WWW. SINCHI.org.Co/2011). 
7. Cynopotamusamazonum (G ÜNTHER, 1868).

Collection number ICN-MHN: 17901.

Subfamily: Cha ra cinae.

Synonymies: Ana c rytuslima esqua mis (COPE, 1878).

Common name: Chango (Caquetá), clear, dog, dentex (Per), cacunda (Bra)

Description: Large species that reached 23 cm of SL of elongated body with a small hump between the dorsal fin and the head, the scales are rough. Its coloration is silver; the caudal and a dipose fins have a yellow hue. Very similar to the Charax species (GÉRY, 1977).

Distribution: 248 m.a.s.l.; it wa s only captured at the confluence (Venecia sector) with the Ortegüaza river (method of capture: Tra ditional fishing). It is loc ated in the Amazon River basin (GREG ORY-MALDONADO 2006; MALDONADO-OCAMPO et al., 2008; WWW.SINCHI.org.co/2011).

\section{Hemibryc on sp. (G ÜNTHER, 1864).}

Collection number IC N-MHN: 17857, 17858, 17918.

Common name: Yellow tail sardine, tolomba, mojara (Per).

Description: Medium-sized fish that reach $17 \mathrm{~cm}$ in SL, a re dorsally dark and la terally silvery in color; the rays of the a nal fin a re orange oryellow (ORTEGA-LARA et al., 2002).

Distribution: 1100-248 m.a.s.l.; It has a wide distribution in the Hacha river basin (method of capture: tra ditional fishing gear and electric fishing). In Colombia, it is also found in the basin of the Meta,
Magdalena and Amazonas rivers (G REG ORY-MALDONADO et al. 2006, GALVIS et al. 2007).

\section{Hemibrycon sp2. (GÜNTHER, 1864).}

\section{Collection number ICN-MHN: 17855.}

Common name: Thunder sardine (Ca quetá), boquilla (Ecu).

Description: Small species that reached $3.5 \mathrm{~cm}$ of SL of color silver and brown on the caudal region.

Distribution: 635-248 m.a.s.l; it was loc a ted between the Vereda Paraíso until the confluence with the Ortegüaza river (method of capture: Traditional fishing and electric fishing ). It is distributed in the Amazon River basin (G REG ORY-MALDONADO, 2006).

10. Hemibryc on sp3. (GÜNTHER, 1864).

Common name: Sardine, tolomba.

Description: Medium spec ies that rea ched $7 \mathrm{~cm}$ of SL of silver color and prominent lower jaw.

Distribution: 262 m.a.s.l.;it was captured in the area called the forest (capture method: electric fishing). It is loc ated in the Amazon basin, O rinoco and Magdalena (GÉRY, 1977; REIS, KULLANDER, 2003; G REG ORY-MALDONADO, 2006; MALDONADO-OCAMPO et al., 2008).

Observation: First report for the Hacha and Caquetá basin.

11. Hyphessobryc on sp. (FO WLER, 1941). Common name: Tetras, little sardines, Colombian tetra. 
Description: Sma ll species that rea ched $5 \mathrm{~cm}$ of SL. They are characterized by having the internal row of premaxillary teeth with five or more teeth on each side, inc omplete lateral line, a dipose fin and caudal non-scaly.

Distribution: 253-248 m.a.s.l.; It wa s collec ted in the a irport sector until the confluence with the Ortegüaza River (capture method: Elec tric fishing). Maldona do et al. (2008), Gregory-Maldonado (2006) reported it for the Colombian Amazon.

12. Knoduscarlosi (ROMÁN-VALENCIA et al., 2013).

Common name: Little sa rdine.

Description: Sma ll species that reached $6.5 \mathrm{~cm}$ of SL. Compressed body, robust and slender. Full la tera I line, silver color and in the yellow outline, in alcohol it is observed of light brown color.

Distribution: 262-248 m.a.s.l.; It was collec ted in the Floresta sector until the confluence with the Ortegüaza River (capture method: Electric fishing). Román-Valencia et al., (2013) reported it for the Amazon River basin.

13. Moenkha usiarobertsi (G ÉRY, 1964).

Common name: Sa rdine, tetra.

Description: Sma ll species that reached the $7.6 \mathrm{~cm}$ of SL of silver color and with a broad humeral sp ot, its fins a re hya line. In alcohol it is observed in brown and some parts in black.

Distribution: 635-296 m.a.s.l.; It wa s loc ated in the middle basin of the Hacha river (capture method: Electric fishing). Fowler (1943), reported for the Ortegüaza River the species Moenkhausialepidura and Moenkha usia ortegua sa e. Also, it is loc a ted in the Amazon River basin (MOJICA et al., 2005; G REG ORY-MALDO NADO, 2006; MALDONADO-OCAMPO et al., 2008; WWW.SINC HI.org.Co/2011).

14. Odontostilbe cf. caquetae (FO WLER, 1943).

Synonymies: Fug itive Cheirod on, Fugitive Odontostilbe, O madeirae.

Common name: Little sardine, moja rra.

Desc ription: Small fish that rea $\mathrm{ch} 4 \mathrm{~cm}$ of SL. Body elongated and brown, with a silver strip that ends in a dark spot that may or may not cover the caudal peduncle (GÉRY, 1977).

Distribution: 261-248 m.a.s.l.; spec ies c aptured in the area called the López bridge to the confluence with the Ortegüaza river (method of capture: traditional fishing and electric fishing). Galviset al. (2007) and Fowler $(1943,1945)$ reported it in the same region. Gregory-Maldonado (2006) reported it for the Amazon River basin.

15. Sa Iminusaffinis (STEINDAC HNER, 1880). Collection number ICN-MHN: 17910.

Subfamily: Sa Iminina e.

Common name: Golden, beaked, blonde, lady (Ecu), male shad (Per).

Description: Medium sized fish that reached $32 \mathrm{~cm}$ of SL. Elongated body shape; caudal without elongation, the caudal lobes a re pink-intense red towards the tips, at the 
base of the yellow fin and a black stripe towards the peduncle, red anal fin, the operculum is a lso pinkish-reddish, the fins present the color yellow, the dorsal part of the body is silver gray and the ventral part white-yellowish (MOJ ICA et al., 2012).

Distribution: 890-253 m.a.s.l.; It was loc a ted from the vereda Sucre to the a irport sec tor of the munic ipa lity of Florencia (method of capture: Tra ditional fishing). It was reported for the Magdalena and Ama zonas river basins (MOJ ICA et al. 2005; G REG ORY-MALDONADO et al. 2006; MALDONADO-OCAMPO et al. 2008; WWW. SINCHI.org.Co/2011).

Observation: In The Red Book of Freshwater Fishes of Colombia, it is classified as vulnerable in the IUC N category ( $A 2 \mathrm{C}$, d) - National in Danger (B1bii, B1ciii) Regional (MOJ ICA et al., 2012). It is a Iso the first report for the basin of the Hacha and Caquetá river.

16. Pristobryc onc almoni (STEINDAC HNER, 1908).

Collection number IC N-MHN: 17912.

Subfamily: Serra sa Imina e.

Synonymies: Se rra sa Imusc a Imoni, S. bilineatus, Pygocentrusb ilineatus.

Common name: Piranha, white piranha (Bra), Caribbean (Ven).

Description: Medium sized fish that reached $12 \mathrm{~cm}$ of SL of silver and orange coloration on the base of the anal, dorsal and adipose fin. Lower jaw prominent.

Distribution: 296-248 m.a.s.l.; It wa s c ollected from the sector called the first bridge to the confluence with the Ortegüaza river (method of capture: traditional fishing). It was reported for the Amazon and Orinoco river basins (MOJ ICA et al., 2005; GREG ORY-MALDONADO 2006; MALDONADO-OCAMPO et al., 2008).

17. Serrasalmusrhombeus (LINEUS, 1766). Collection number ICN-MHN: 17911.

Subfamily: Serra sa Imina e.

Synonymies: Pygocentrusno ma ni, Serra sa Imo humera lisgra cilior, S. imma cula tus, S. normani, S. paraense.

Common name: Piranha, fist, Caribbea $n$ (Orinoco), black piranha (Bra).

Description: Medium fish that reached $13 \mathrm{~cm}$ of SL of orange coloration with met al.lic gray a reas, caudal fin with black border. Border of the elongated lower jaw with well-developed teeth (CASTRO, 1997).

Distribution: 296-248 m.a.s.l.; It was collec ted in the area called the first bridge to the confluence with the Ortegüaza river (method of capture: traditional fishing). Also, it is located in the basin of the Amazon River, Putumayo, Caquetá and Guavia re (GÉRY, 1977; MOJ ICA, et al., 2005; GREG ORY-MALDO NADO , 2006; MALDONADO-OCAMPO et al., 2008; WWW.SINCHI.org.co/2011).

18. Tetragonoptenus argenteus (C UVIER, 1816).

Collection number ICN-MHN: 17912.

Subfamily: Tetragonopterinae.

Common name: Palometa (Caquetá), Golden (Leticia), sabaleta, matupiri (Bra). 
Description: Medium fish that reached $13 \mathrm{~cm}$ of SL of silver colora tion and on the ventral edge of yellow color. It has a high, discoidal, deep and compressed body that differentia tes it from the Moenkha usia genus (GÉRY, 1977).

Distribution: 262-248 m.a.s.l.; It wa s loc ated in the urban area of the municipality of Florencia to the confluence with the O rtegüaza River (method of capture: Tra ditiona I fishing). Celis (2010) reported it for the Quebrada la Venado tributary of the Bodoquero River (Morelia-Caquetá). In the same way, it is located in the Amazon basin (MOJICA et al., 2005; MALDONADOOCAMPO et al., 2008; WWW.SINC HI.org. co/2011).

\section{Discussion}

Due to the few works developed on fish composition in the Colombian Amazonian Andean region, particularly in the Piedmont region of Caquetá, its wealth has been und erestima ted. In fact, the only investigations for the Hacha River Ba sin that address fish composition are that of Chaves (2011) for the order Siluriformes and Perdomo et al. (2012), this last a uthor reported 13 species for the order Characiformes, of which he didn't report for the Characidae family. Fowler $(1943,1945)$ reported 5 species for Caquetá, referenced in the present work. Likewise, 5 species of the Characidae family coincide with the reports made by Galvis et al. (2007) for the department (Annex C). Therefore, the 18 species collected in this basin can predict that the ric hness for the order Cha raciformes can reach 30 species, since they would increase by more than 10 species.

This research is a good a pproximation to the total number of species of the Characidae family present in the basin, considering the size of the basin, the explored places, the scarce records of species and the uncerta inties that a rise over existing id entific a tions (C HERNO FF et a l., 1999). In relation to the abundance and composition of the Characidae fa mily (459 ind (18sp) it is the one with the greatest contribution to the Characiformes order, since from the global study it showed only 70 individuals belonging to 11 species (families: Anostomidae, Crenuchidae, Curima ta dae, Erytrinidae, Hemiod ontidae, Pa rodontidae, Proc hilod ontidae) coinc id ing with other a uthors in several systems of the Amazon basin (SILVANO et al., 2000, LASSO et al., 2004).

Fishing in the munic ipality of Florencia is directly related to economic (income) and social a ctivities (population growth vs. food) (POMCA, 2005). However, according to the observation in the field and conversation with members of the community, it was identified that most of the species a re used in subsistence fishing; young fish are usually caught, which leads to the interruption of the reproductive cycle of the species and the consequent decrease in their populations. Among the ma in methods used for fishing a re hooks, trammel nets, fishing guns and cast nets.

Also, other factors that threaten the ic hthyofauna a re a gric ultural, domestic and ind ustrial pollution; these actions, added 
to the limited distribution ranges, place the fish at extinction risk levels. Therefore, of the 18 species referenced the only one that is in danger (vulnerable national category: A2c, d) according to Trehe Red Book of Freshwater Fishes of Colombia is Sa Iminus cf. a ffinis (MOJ ICA et al., 2012). Consequently, even though Sa Iminus cf. Affinis is in vulnerable danger, at the local level it is unknown that other species of fish may be in the same situation due to lack of studies.

Finally, it is urgent that research programs on the biology of species and the state of aquatic ecosystems be encouraged. Also, it is feasible to propose as conservation measures for the Hacha river basin the compliance with the regulation on the minimum sizes of capture and in general of the fishing and commercialization activity, through total or partial c losures during the reproduction periods.

As a conclusion, it can be indic a ted that the ric hness of species is high, partic ula rly in the lower basin of the HachaRiver. The most abundant and most widely distributed spec ies was Hemibryc on sp. (151), Boehlkea

\section{References}

ALBERT, J.S., BART, H.J. and REIS, R.E., 2011. Species richness and cladal diversity. Historical Biogeography of Neotropical Freshwater Fishes. University of California Press, Berkeley. pp. 89-104.

CASTRO, D., 1997. Peces del Rio Putumayo, Sector de Puerto Leguizamo. Corporación para el Desarrollo Sostenible del Sur de la Amazonia "CORPOAMAZONIA". $174 p$. cf. fred coc hui (88), Crea grutusa moenus (50) and Creagrutusc ochui (35). Also, of the 18 species collected, all are new reports for the basin, 12 in the department and one (1) in the Colombian Amazon.

\section{Acknowledgements}

The a uthorsthank the Universities of the Amazonia, Nacional and Nava ra (Spa in) for the loan of equipment and collections. Also to the CODECYT + I agreement $\mathrm{N}^{\circ}$ 098 of 2010 between Colciencias and Gobemación de Caquetá for the financial support through the young investigator scholarship. Also, we thank the different tea chers (Rafael Miranda, Dona ITha phorn, Germá nGa Ivis, J o sé Iván Mojica, Monica Shirley C elis, J a ime Velásquez, Alexa nder Velá squez and J ona tha $n$ Garaviz) for the comments and suggestions to this document and finally thank FAPESP (Fundacao de Amparo a la Pesquisa do Estado de Sa o Paulo - Brazil) and Professors J osé Galicia Tundisi and Takako Matsumura-Tundisi for the opportunity offered to carry out the Integrated Water Resources Management course and to socialize the research.

CELIS, M.S. and ORTIZ, J.L., 2003. Contenido Estomacal del Denton (Hopliasmalabaricus, bloch 1794) en una Madre Vieja del Piedemonte Amazónico. Universidad de la Amazonia. Trabajo de grado. 70p.

CELIS, M.S., 2010. Estructura de la comunidad íctica en un arroyo del Piedemonte Amazónico (Florencia Caquetá). Universidad Nacional de Colombia sede Leticia. Tesis de Maestría. Leticia - Amazonas. 44p. 
CHAVES, L.C., 2011. Distribución altitudinal de la familia Loricariidae en la región Andino-Amazónica Colombiana (cuenca del río Hacha, FlorenciaCaquetá). Universidad Nacional de Colombia; sede Leticia. Tesis de Maestría. 84p.

CHERNOFF, B., WILLINK, P., SARMIENTO, J., BARRERA, S., MACHADO-ALLISON, S., MENEZES, N. and ORTEGA, H., 1999. Fishes of the Rios Tahuamanu, Manuripi and Nareuda, Depto. Pando, Bolivia: Diversity, Distribution, Critical Habitats and Economic Value. pp. 39-46.

DIAZ, A.C. and ESCOBAR, F.R., 2004. Composición y abundancia Ictica de la Madre Vieja del rio Hacha en la Granja Villa Paola (Florencia, Caquetá) durante los meses de enero a junio de 2004. Universidad de la Amazonia. Tesis de grado. 65p.

ELOSEGI, A. and SABATER, S., 2009. Conceptos y Técnicas en Ecología Fluvial. BBVA. España. 424p.

FOWLER, H.W., 1943. Colección de peces de agua dulce de Colombia, Obtenida Principalmente por Hermano Nicéforo, María. Proceedings of the Academy of Natural Sciences of Philadelphia, vol. 95, pp. 223-266.

FOWLER, H.W., 1945. El estudio zoológico Colombiano Parte I: Peces de agua dulce. Proceedings of the Academy of Natural Sciences of Philadelphia, vol. 97, pp. 93-135.

GALVIS, G., MOJICA, J.I., BELTRAN, L.M., CIPAMOCHA, C.A. and LEIVA, M., 2007. Peces de la Amazonia Colombiana con Énfasis en Especies de Interés Ornamental. Ministerio de Agricultura y Desarrollo Rural. INCODER. Universidad Nacional de Colombia. Bogotá D.C. 489p.

GÉRY, J., 1977. Characids of the World. Printed in the U.S.A. 647p.

GÉRY, J., 1984. The fishes of Amazonia en: H. Sioli (Ed.), The Amazon: Limnology landscape ecology of a mighty tropical river and its basin. Monographiae Biologicae. vol. 56. Dr Junk Public. Dordrecht. pp. 353-370.

GREGORY, J.D and MALDONADO-OCAMPO, J., 2006. Peces de la Zona Hidrogeografica de la Amazonia, Colombia. Instituto de Investigaciones en Recursos Biológicos Alexander von Humboldt. Biota Colombiana, vol. 7, no. 1, pp. 55-94.
LASSO, C.A., MOJICA, J.I, USMA, J.S, MALDONADOOCAMPO, J.A., DONASCIMENTO, C. TAPHORN, D.C., PROVENZANO, F., LASSO-ALCALÁ, O.M., GALVIS, G. VÁSQUEZ, L., LUGO, M., MACHADO-ALLISON, A., ROYERO, R., SUÁREZ, C., ORTEGA-LARA, A., 2004. Peces de la cuenca del río Orinoco. Parte I: lista de especies y distribución por subcuencas. Biota Colombiana, vol. 5, no. 2, pp. 95-158.

LOBÓN-CERVIÁ, J., 1991. Dinámica de poblaciones de peces en ríos. Pesca eléctrica y métodos de capturas sucesivas en la estima de abundancias. Museo Nacional de Ciencias Naturales C.S.I.C., Madrid. 156p.

MALABARMA, L.R., 2003. Subfamily Cheirodontinae (Characins, tetras). pp. 215-221. En: Reis R.E., KULLANDER, S.O. y FERRARIS Jr., C.J. (eds.). 2003. Checklist of the Freshwater Fishes of South and Central America. Edipucrs. Porto Alegre, Brasil. 729p.

MALDONADO-OCAMPO, J.; ORTEGA, A., GALVIS, G., VILLA, F., VÁSQUEZ, L., PRADA, S., ARDILA, C., 2006. Peces de los Andes de Colombia. Guía de Campo. Instituto de investigaciones de Recursos Biológicos "Alexander Von Humboldt". Bogotá D.C-Colombia. $346 p$.

MALDONADO-OCAMPO, J., VARI, R.V., USMA, J.S., 2008. Checklist of the Freshwater Fishes of Colombia. Biota Colombiana, vol. 9, no. 2, pp. 143-237.

MOJICA-C, J.I., 1999. Lista Preliminar de las especies de peces dulceacuícolas de Colombia. Revista de la Academia Colombiana de Ciencias Exactas, Físicas y Naturales. vol 23, no. supl. esp. pp. 546-566.

MOJICA J.I, GÁLVIS, G., ARBELÁEZ, F., SANTOS, M., VEJARANO, S., PRIETO-PIRAQUIVE, E., ARCE, M., SÁNCHEZ-DUARTE, P., CASTELLANOS, C., GUTIÉRREZ, A., DUQUE, S. LEVON-GARCÍA, J. and GRANADOLORENCIO, C., 2005. Peces de la cuenca del río Amazonas en Colombia: Región de Leticia. Biota Colombia, vol. 6, no. 2, pp. 191-210.

MOJICA, J.I., USMA, J.S., ÁLVAREZ-LEÓN, R., and LASSO, C.A., 2012. Libro rojo de peces dulceacuícolas de Colombia 2012. Instituto de Investigación de Recursos Biológicos Alexander von Humboldt, Instituto de Ciencias Naturales de la Universidad Nacional de Colombia, WWF Colombia y Universidad de Manizales. Bogotá, D. C., Colombia, 319p. 
MOYLE P.B. and CECH, J.J., 2004. An introduction to ichthyology. Prentice Hall, Upper Saddle River, New York, USA. 726p.

NELSON, J.S., 2006. Fisches of the World. New York, John Wiley y Sons. 624p.

ORTEGA-LARA, A., AGUIÑO, A. and SÁNCHEZ, G.C., 2002. Caracterización de la ictiofauna nativa de los principales ríos de la cuenca alta del río Cauca en el departamento del Cauca. Informe presentado a la Corporación Autónoma Regional del Cauca, CRC. Fundación para la Investigación y el Desarrollo Sostenible, Funindes. Popayán, Colombia. 139p.

ORTEGA-LARA, A., MOJICA, J.I., ALONSO, J.C. and HIDALGO, M., 2006. Listado de Peces de la cuenca del Rio Putumayo en un sector Colombo-Peruano. Universidad Nacional de San Marcos, Lima. Universidad Nacional de Colombia. Instituto SINCHI. Biota Colombiana, vol. 7, no. 1, pp. 95-112.

PELÁEZ, R.M., GARCÍA, H. and MENDEZ, G.C., 2006. Caracterización y cuantificación de la carga contamínate transportada por el río Hacha (Florencia Caquetá). In: Neolimnos. VII Seminario Colombiano de Limnologia. Ibagué. pp. 17-28.

PERDOMO, A., VELÁSQUEZ, V.A. and CELIS, G.M., 2012. Análisis de la Composición espacial de la Comunidad de peces de la Cuenca Media del Río Hacha. Universidad de la Amazonia. Rev. Momentos de ciencia, vol. 9, no. 2, pp. 120-126.

POMCA, 2005. Plan de ordenación y manejo de la cuenca del río Hacha 2005-2025. Convenio 051 de 2004. 25p.
REIS, R., JAMES and KULLANDER, J. C., 2003. Check list of the freshwater fishes of south and Central America. Pontifícia Universidade Católica do Rio Grande do Sul. Porto Alegre. 729p.

ROMÁN-VALENCIA, C; RUIZ-C., R. I; TAPHORN, B. D. C. and GARCÍA-A., C., 2013. Three new species of Bryconamericus (Characiformes, Characidae), with keys for species from Ecuador and a discussion on the validity of the genus Knodus. Animal Biodiversity and Conservation, vol. 36, no. 1, pp. 123-139p.

RUBIO, E., 2007. Introducción a los Peces Dulceacuícolas de Colombia. Universidad del Valle. Impreso Cali Colombia. 404p.

RUEDA, D. M. and ALMARIO, A.R., 2004. Biosistemática de peces Eléctricos (Ostariophysi: Ginnitiformes) en Ecosistemas Acuáticos del Piedemonte Amazónico. Universidad de la Amazonia. Trabajo de grado. 55p.

SILVANO, R.A.M., DO AMARAL, B.D. and OYAKAWA, O.T., 2000. Spatial and temporal patterns of diversity and distribution of the upper Juruá River fish community (Brazilian Amazon). Environmental Biology of Fishes, vol. 57, no. 1, pp. 25-35.

VARGAS-TISNES, I.C., 1989. Inventario preliminar de la ictiofauna de la hoya hidrográfica del Quindío. Corporación Autónoma Regional del Quindío. Editorial Icnografía. Armenia, Colombia. 96 p. Available in: www.sinchi.org.co/coleccionesbiologicas/index.php 
ANNEXES

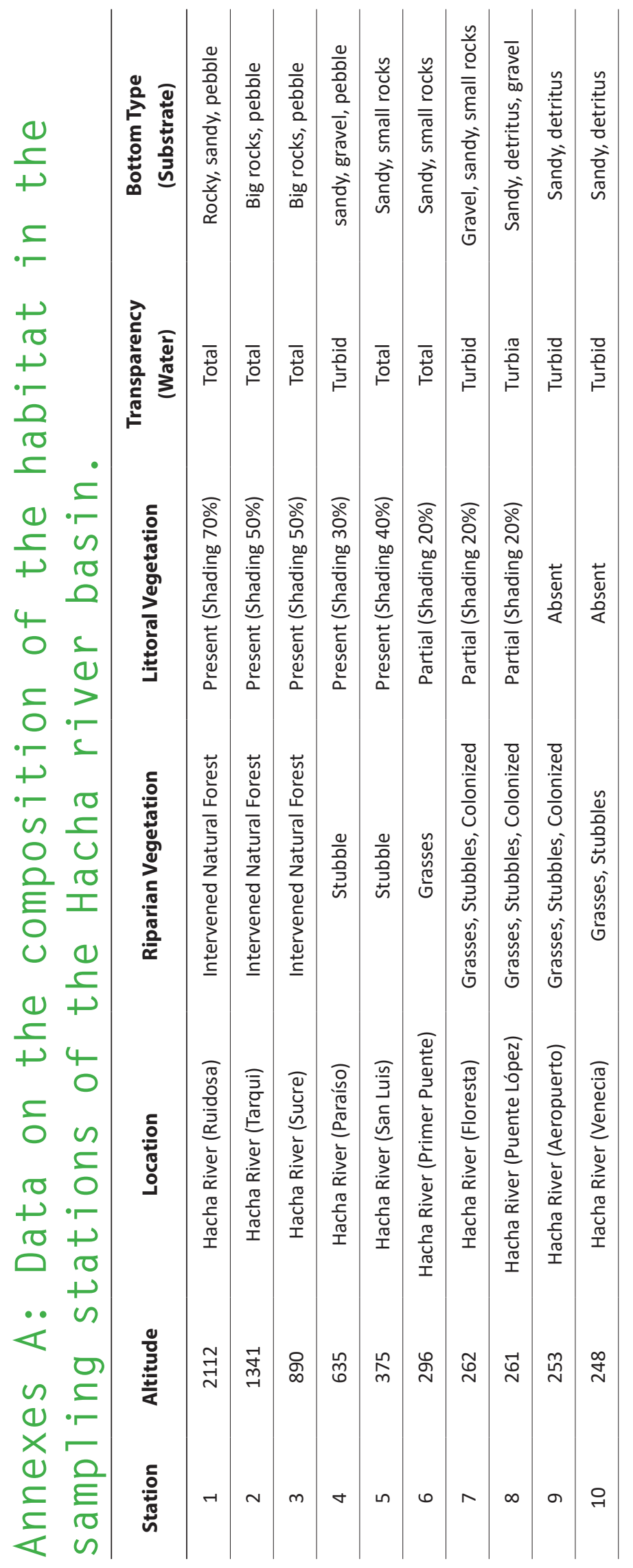




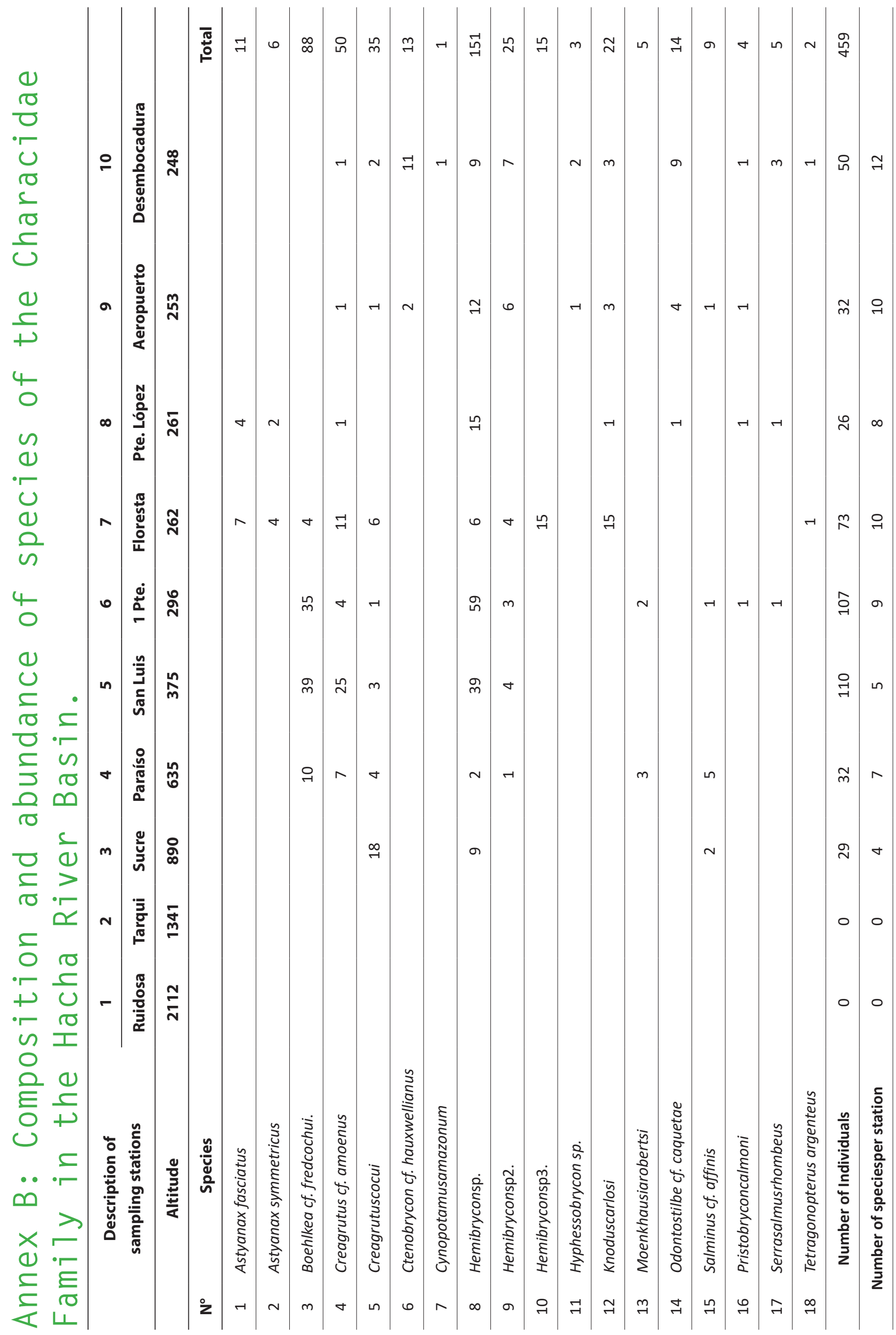




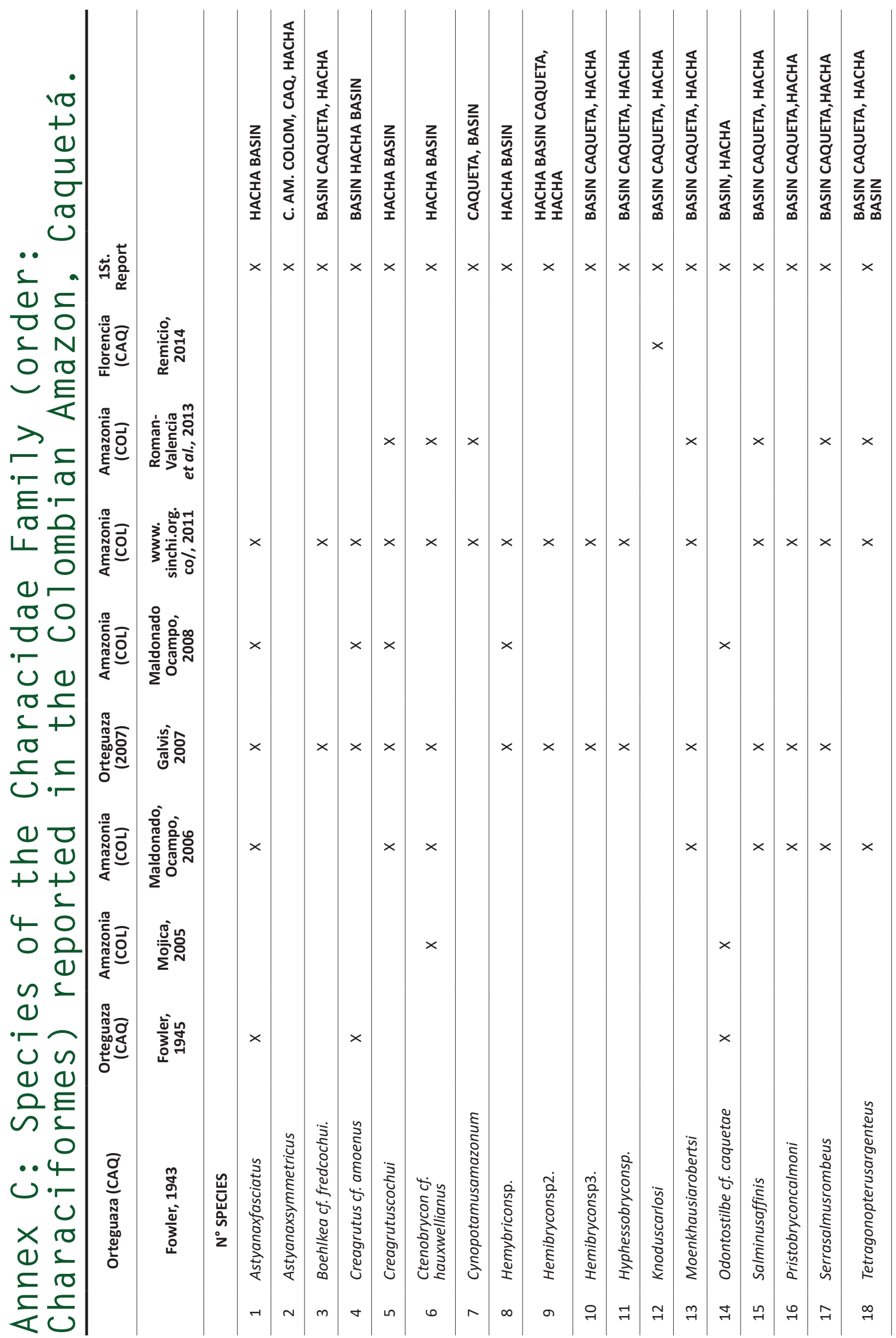




\title{
The Fluvial Forests as Indicators of the Flow and Permanence of Water
}

\author{
Za mbia sio, V.A. ${ }^{1}$, Casc o, S.L., Neiff, J J .
}

${ }^{1}$ Centro de Ecología Aplicada del Litoral - CONICET-UNNE, Corrientes, Argentina.

Corresponding author: violetazambiasio@gmail.com

\section{Abstract}

We evaluated the influence of the horizontal flows of the Para ná River on the composition and distribution of the floodplain landscape and we defined the ecohydrological signature of some species-index in the low Paraná River section, ( $27^{\circ} 38^{\prime}$ 04" S and $\left.58^{\circ} 50^{\prime} 46^{\prime \prime} \mathrm{W}\right)$. During the drought phase, the structure of the vegetation were characterizad using a Cotta $m \&$ Curtis method. The trees were positioned in the topographic gradients during the flood phase, taking as reference the river water sheet in the nearest hydrometric gauge. To obtain the pulse attributes in different positions of the geomorphological gradient, PULSO software was used considering the daily water levels at Comientes city between 1985 and 2015. Two main types of flooded forests were identified: pionner forest, dominated by one or two species (Sa lix humboldtiana, Tessaria integrifolia) in recent bars and islands, and pluri-specific flooded forests (Albizia inundata, Cecropia pachystachya, Croton uruc urana, Inga uruguensis, Ocotea diospyrifolia, Nectandra angustifolia and Peltophorum dubium) occupying bars of the highest islands, with shorter flood phases, with trees a re distributed in 2-3 strata in a closed canopy. Pulses were more frequent in pioneer forests than in multispecific forests. The ecohydrological signa ture allows the optimum condition and distribution limits of each species to be established. It is a tool to know the adjustment of biotic elements (populations) to the river variability regime. The procedure used can be used to anticipate the possible reorganization of the river pla in landscape as a result of flow variations predicted by climate change models.

Keywords: hydrologica I regime, pulses, Pa ra ná River, floodpla ins, ec ohydrology, climatic change. 


\section{Introduction}

Since the beginning of vegetation ecology, attention has been foc used to know the number of species that inhabit a river and its basin. Few projects have been devoted to studying the causes of biodiversity in systems with a high fluctuation level. In this contribution we a nalyze an approach to link the vegetation composition as a consequence of the river regime on each site of the floodplain. Following the Pulse concepts (J UNK et al., 1989, NEIFF, 1990, 1996) we attempt to know the relationship between the tree populations distribution and the pulse attributes. The vegetation, and espec ia lly the forests, are the most conspicuous struc tures and of greater permanence in the fluvial landscape. There is a clear a symmetry a long the river between the floodplain vegetation and the adjacent phytogeographic territories to the Paraná River (CABRERA, 1976).

\section{Objectives}

To evaluate the influence of the horizontal flows of the Pa ra ná River, on the composition and distribution of the fluvial forests.

To define the ecohydrologic al signature of some species of trees in the study area.

\section{Materials and Methods}

This study was ca rried out in the floodpla in of the Para ná River, in Argentina, upstream of Pa raná-Pa ra guay confluence (2738' 04' 'S and 58 50' 46" W, Figure 1). During the drought phase (limnophase), we study the vegetation structure by the centered quadrants method (COTTAM; CURTIS, 1956). The trees were positioned during the flood phase (potamofase) in the topographic gradient taking as reference the river water sheet in the nea rest hyd rometric gauge (Neiff, 1986). PULSO softwa re (NEIFF; NEIFF, 2003) was used to obtain the pulse attributes in different positions of the geomorphic gradient. Between 1985 and 2015, daily records the water level in Corrientes city was a nalyzed. More than a thousand points were measured to cover all possible sites where each of the nine ind ic ator species considered is growing.

\section{Results}

According to our results, it is possible to differentia te two types of forests: the pioneer forests, dominated by Salix humboldtiana and / or Tessaria integrifolia, in low bars, between 45.71 and 48.01 m.a.s.l.. These forests constitute a habitat of very wide variability (water level, runoff velocity, erosion/ sedimentation and nutrient dynamic). The populations that live there can respond to disturbances. The germination phase are short and the vegetative growth is very fast. Plants invest a lot of energy in maintaining a long period of fertility to synchronize the production and release of fruits and seeds in a favorable hydrological phase. As a typic al "r" stra tegists. 
The other type of fluvial forests (mixed gallery forest), growth in the higher position of the topographical gradient, with a lmost 20 sp p., represented by Albizia inundata, between 46.21 and 48.01 m.a.s.l.; Cecropia pa chysta chya (between 46.11 and 48.01 m.a.s.l.); C roton urucurana (between 46.21 and 48.01 m.a.s.l.), Inga uruguensis (between 47.71 and 48.01 m.a.s.l.); Ocotea diospyrifolia (between 46.21 and 48.01 m.a.s.l.); Nectandra angustifolia (between 46.21 and 48.01 m.a.s.l.) and Peltophorum dubium (between 46.21 and 47.01 m.a.s.l.). These forest occupy bars or marginal levees, where the flood phase is shorter, the sediments have more fine materia ls and the soil has more organic matter in surface. The trees a re distributed in 2-3 stra ta with a continuous canopy. They produce an important interference in the flow during extra ord ina ry floods (NEIFF et al., 2006).

In the last twenty years, Paraná River had a irregular regime, with two extra ordinary floods which exceed $8 \mathrm{~m}$ in Corrientes gauge (Figure 2). The pulses were more frequent in pioneer forests than the multiespecific forests (Table 1), that is to say, they are functionally connected to the river flow more times in the sa me time series.

$58^{\circ} 52^{\prime} 0^{\prime \prime} \mathrm{W} 58^{\circ} 51^{\prime} 0^{\prime \prime} \mathrm{W} 58^{\circ} 50^{\prime} 0^{\prime \prime} \mathrm{W} 58^{\circ} 49^{\prime} 0^{\prime \prime} \mathrm{W} 58^{\circ} 48^{\prime} 0^{\prime \prime} \mathrm{W} 58^{\circ} 47^{\prime} 0^{\prime \prime} \mathrm{W} 58^{\circ} 46^{\prime} 0^{\prime \prime} \mathrm{W} 58^{\circ} 45^{\prime} 0^{\prime \prime} \mathrm{W}$

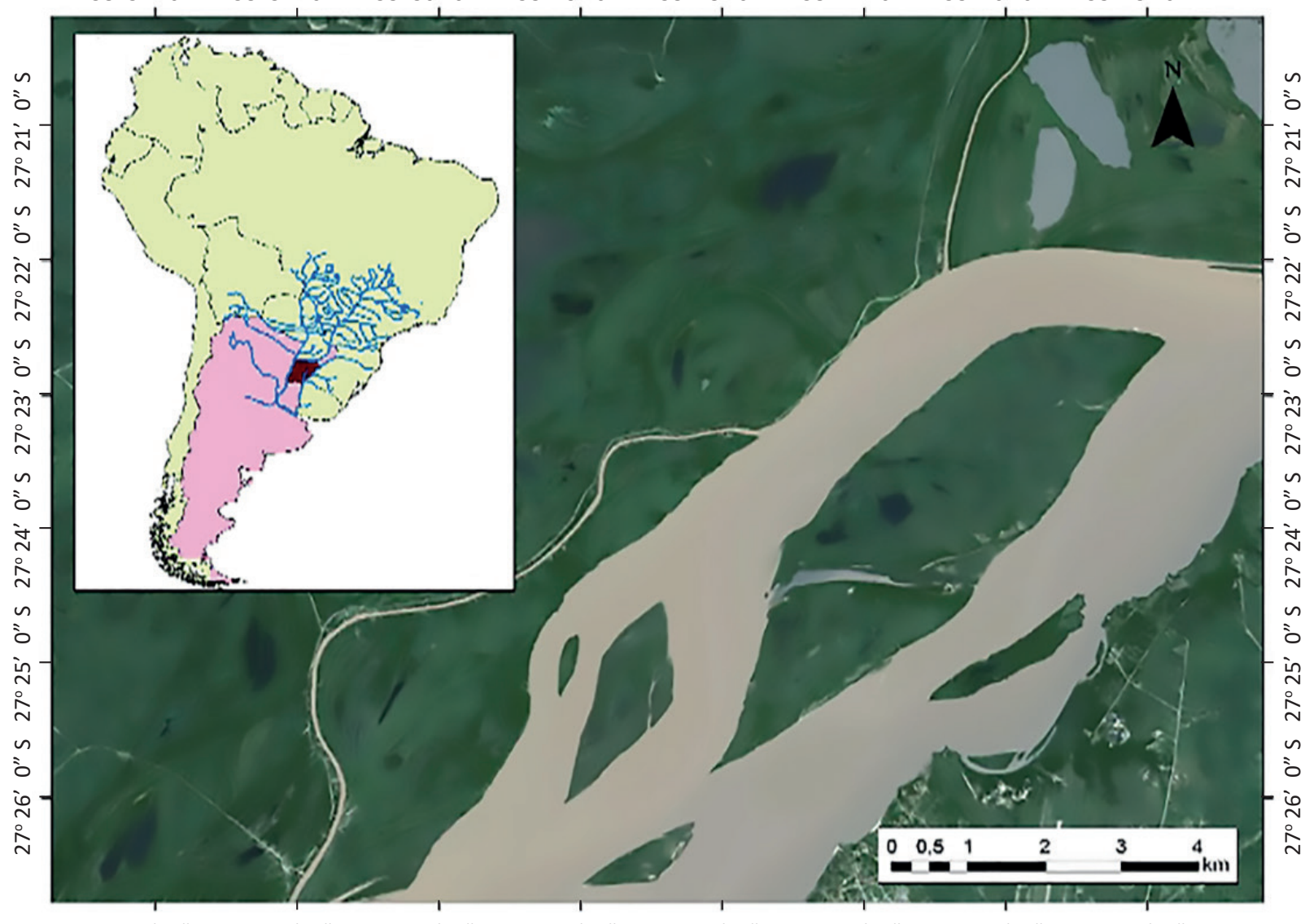

$58^{\circ} 52^{\prime} 0^{\prime \prime} \mathrm{W} 58^{\circ} 51^{\prime} 0^{\prime \prime} \mathrm{W} 58^{\circ} 50^{\prime} 0^{\prime \prime} \mathrm{W} 58^{\circ} 49^{\prime} 0^{\prime \prime} \mathrm{W} 58^{\circ} 48^{\prime} 0^{\prime \prime} \mathrm{W} 58^{\circ} 47^{\prime} 0^{\prime \prime} \mathrm{W} 58^{\circ} 46^{\prime} 0^{\prime \prime} \mathrm{W} 58^{\circ} 45^{\prime} 0^{\prime \prime} \mathrm{W}$

Figure 1 - Location of study area. 
Table 1 - Pulse at tributes during 1985-2015.

\begin{tabular}{lcc}
\hline \multicolumn{1}{c}{ Pulse attributes } & Pioneer forests & Multiespecific forest \\
\hline Overflow level (m.a.s.l.) & $46.39(4 \mathrm{~m})$ & $48.39(6 \mathrm{~m})$ \\
\hline Mean amplitude (days) & 72.2 & 319.08 \\
\hline Mean intensity (m) & 2.44 & 3.3 \\
\hline Pulse frequency & 156 & 35 \\
\hline Mean water level (m) & 3.95 & 3.95 \\
\hline Maximun mean (m) & 6.41 & 1.18 \\
\hline Minimum mean (m) & 2.14 & 0.71 \\
\hline Maximum tension & 61.11 & 61.11 \\
\hline Minimum tension & 65.44 & 65.44 \\
\hline Maximum (m) & & \\
\hline Minimum (m) & \multicolumn{3}{c}{1.64 (30 Aug. 2001) } \\
\hline
\end{tabular}
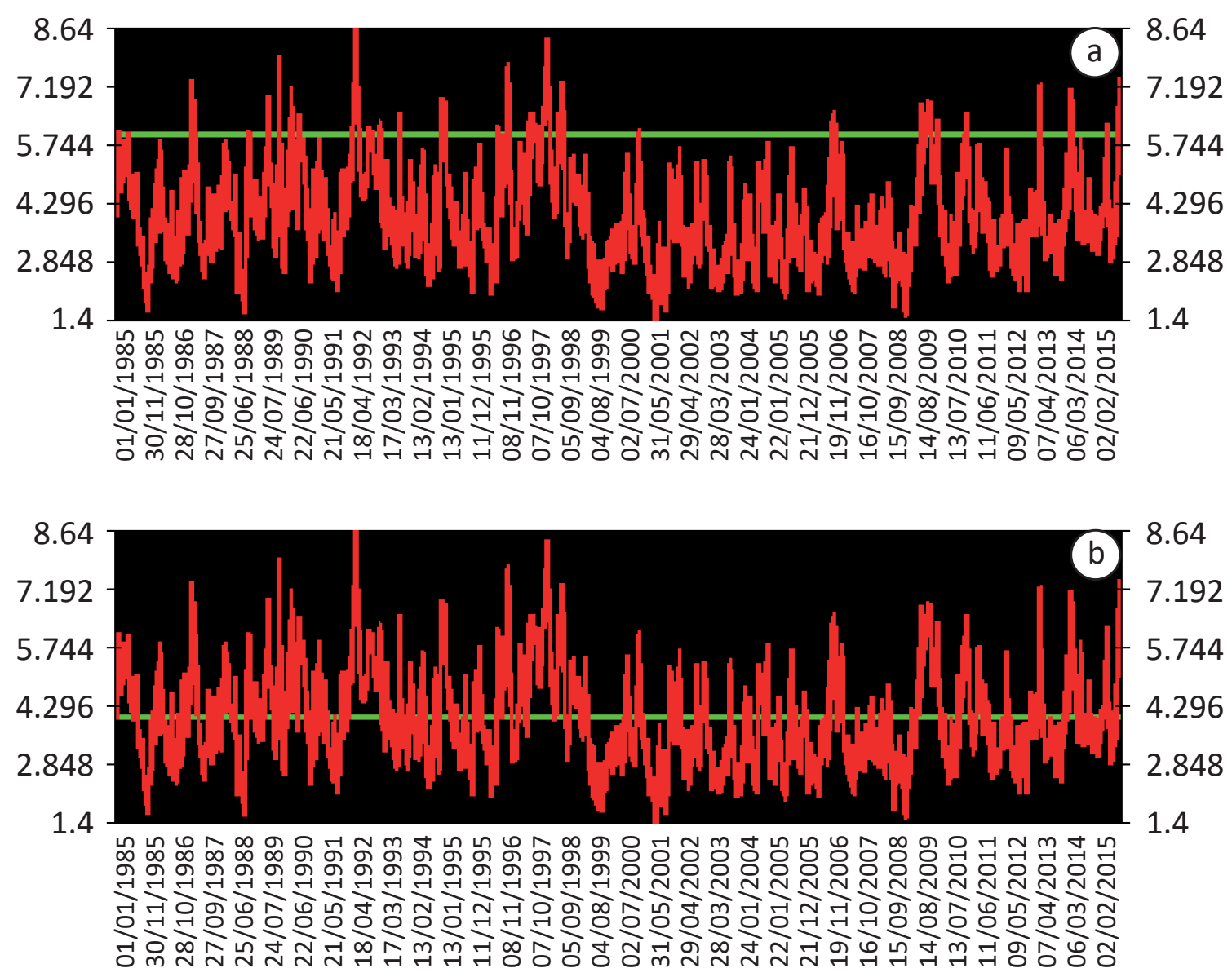

Figure 2 - Water level fluctuations of the Paraná River at Puerto Corrientes between 1985 and 2015. a. Overflow level of pioneer forests: $4 \mathrm{~m}$; b. Overflow level of multiespecific forests: $6 \mathrm{~m}$. 


\section{Conclusion}

The multiespecific forests a re located in the highest sites of the islands and the populations of the pioneer forests occupy the lowest sites of the topographic gradient. Knowledge of the distribution and abundance of organisms allows understanding the biotic complexity of the system, its tempora I variability and the possibilities of organisms to colonize and maintain themselves in pulsatile environments of the rivers.

The species ric hness is conditioned by the frequency intensity, duration and timing of the hydrological phases. The current specific richness has a configuration that must be evaluated knowing the processes

\section{References}

CABRERA, A.L., 1976. Regiones fitogeográficas argentinas. 2. ed. Enciclopedia Argentina de Agricultura y Jardinería. ACME, Buenos Aires. 1-85 pp.

CASCO, S.L., NEIFF, M. and NEIFF, J.J., 2005. Biodiversidad en ríos del litoral fluvial. Utilidad del software PULSO. INSUGEO. Miscelánea, vol. 14, pp. 419-434.

COTTAM G. and CURTIS, J.T., 1956. The use of distance measures in phytosociological sampling. Ecology, vol. 37, no. 3, pp. 451-460.

FEARO - Federal Environmental Assessment Review Office, 1978. Ecological land survey guidelines for environmental impact analysis. Ecological Land Classification Series. Federal Environmental Assessment and Review Process. Lands Directorate Environment Canadá, vol. 13, pp. 42.

JUNK, W.J., BAYLEY, P. and SPARKS, R.E., 1989. The flood pulse concept in river floodplain systems. In: D.P. Dodge, ed. Proceedings of the International Large River Symposium (LARS). Canadian Special Publication of Fisheries and Aquatic Sciences, vol. 106, pp. 110-127. that regulate positively or negatively by the phases of the pulses. PULSE, can be seen as a tool to link the orga nization of biotic communities with the characteristics of the pulses (frequency, intensity, duration and sea sonality). The a nalysis of periodic hydrological phenomena is a tool to understand why fluvial vegetation can be differentiated from the surrounding ec osystems, even from a sa tellite. Climatic changes that modify the hydrological dynamics influence the biodiversity of each site, by modifying the frequency, duration and seasonality of the flooded soil / dry soil phases of the site. These causes of biological settings on a site and in a basin require a nalysis at different sc ales: c urrent evolutionary suc esionaly.

NEIFF, J.J., 1986. Aquatic Macrophytes of Paraná River. In: The Ecology of River Systems. Walker, K.F. y Davies, B.R. (eds.). Dr. Junk Publ. The Netherlands. pp. 557-571.

NEIFF, J.J., 1990. Ideas para la interpretación ecológica del Paraná. Interciencia, vol. 15, no. 6, pp. 424-441.

NEIFF, J.J., 1996. Larges Rivers of South America: toward the new aproach. Verh. Internat. Verein. Limnol. vol. 26, pp. 167-180.

NEIFF, J.J. and NEIFF, M., 2003. PULSO, software para análisis de fenómenos recurrentes. Dir. Nac. de Derecho de Autor № 236164 (Argentina) Buenos Aires, 17 de febrero. http://www.neiff.com.ar.

NEIFF, J.J., PATIÑO, C.A.E. and CASCO, S.L., 2006. Atenuación de las crecidas por los humedales del Bajo Paraguay, 261-276 p. En: Humedales fluviales de América del Sur. Hacia un manejo sustentable. Fundación Proteger. 350 p. 



\section{Geographical Distribution of Calanoida Species (Copepoda-Crustacea), at 22 UGRHi of São Paulo State - Brazil}

Matsumura-Tund isi, T. ${ }^{1}$, Tundisi, J.G. ${ }^{2}$

IInternational Institute of Ecology of Sã o Ca rlos

${ }^{2}$ Feevale University, Novo Hamburgo, RS

Correspondence author: takako@iie.com.br

\section{Abstract}

Geographical distribution of Calanoida species (Copepoda-Crustacea) from São Paulo State were studied considering the 22 UG RHi (Management Units of Hydric Resources). Sa mplings were ca mied out from 250 water ecosystems including small lakes, reservoirs and rivers during the period of 1999 to 2001 . Some species showed a large geographical distribution occuming in a lmost all water ec osystems registered in 22 UG THi. Other species occurred only in the waters of some UGRHi showing a narrow range of geographical distribution. This behavioral difference showed by the speciescan be attributed to several environmental fac tors: clima tologic al conditions, biogeoc hemic al factors, inter spec ific competition for food, habitat and hydrogeochemical factors.

Keywords: eurioecious, stenoecious, clima tologic al factors, biogeochemical factors, new species, interspecific competition. 


\section{Introduction}

São Paulo State is separated by other States through three large rivers: Rio Grande at the north part making border with Minas Gera is State; Rio Paraná at the west part making border with Mato Grosso do Sul and Rio Paranapanema at the south part making border with Parana State. The fourth la rge river Tietê River across the center of São Paulo State from east to west direction to flow into Paraná River.
Based on watershed concept, São Paulo State was divided in 22 UGRHi (Management Units of Hydric Resources) where in each unit a re include its hydric resources. Each unit has its number and the name of the ma in rivers contributors. The following Map shows the 22 UGRHi.

In each UG RHi there are some large dams constructed to the generation of hydroelectric power that will be shown in the Table 1.

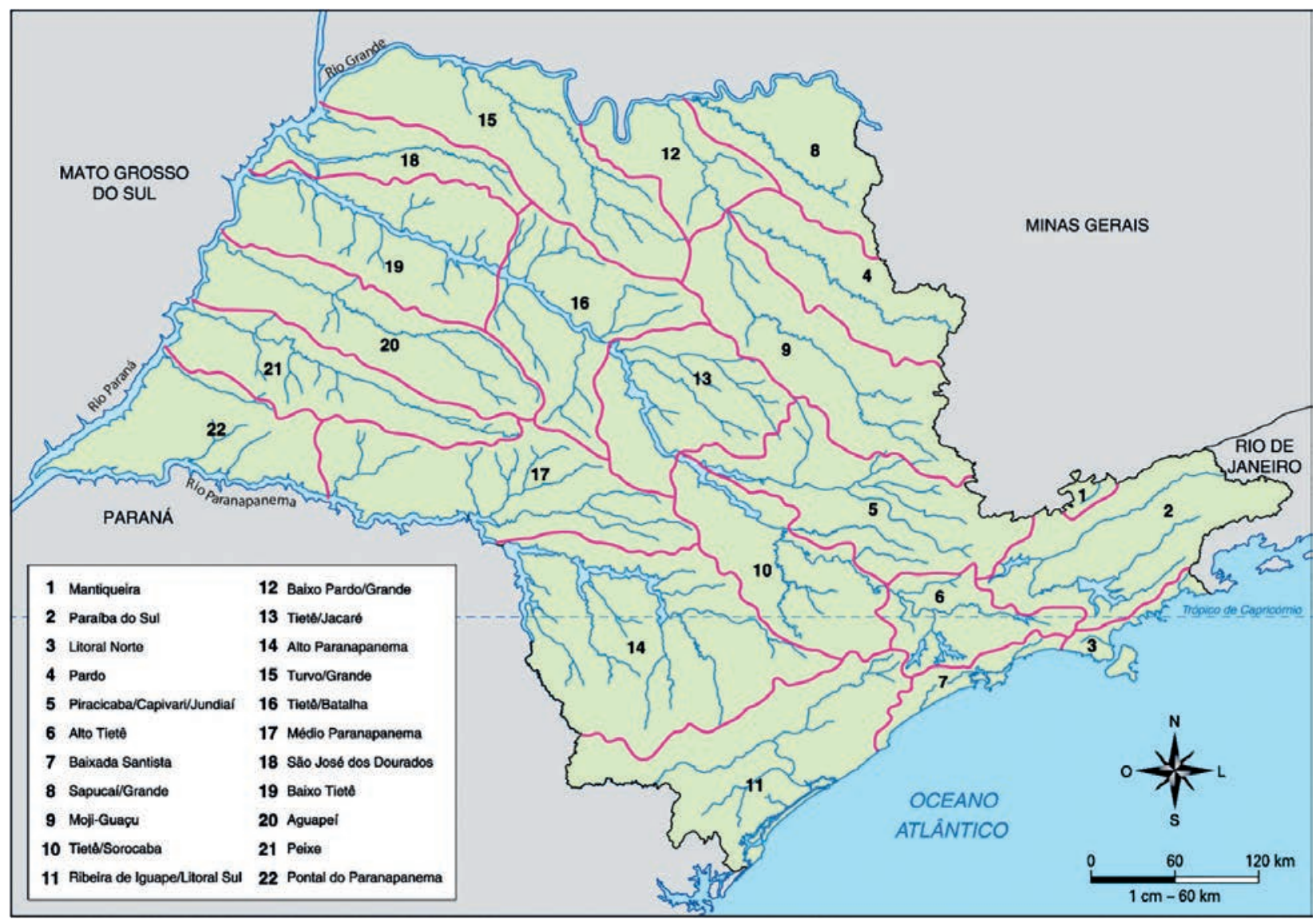

Source: sanderlei.com.br/PT/Ensino-Fundamental/São-Paulo-Historia-Geografia-52 
Table 1 - The main reservoirs belonging to each UGRHi of São Paulo State.

\begin{tabular}{|c|c|c|}
\hline$n^{\circ}$ & UGRHi -Name & Dams construted \\
\hline 1 & Mantiqueira & $x$ \\
\hline 2 & Paraiba do Sul & Paraibuna, Santa Branca,Jaguari, Funil \\
\hline 3 & Litoral Norte & $x$ \\
\hline 4 & Pardo & Graminea (Caconde) \\
\hline 5 & Piracicasba/Capivari/Jundiai & Atibaia,Atibainha, Salto Grande, Jacarei, Cachoeira \\
\hline 6 & Alto Tietê & $\begin{array}{l}\text { Guarapirang, Billings, Paiva Castro } \\
\text { Aguas Claras, Pedro Beicht, Ponte } \\
\text { Nova, Jundiai, Taiaçupeba, Biritiba, } \\
\text { Paraitinga }\end{array}$ \\
\hline 7 & Baixada Santista & $x$ \\
\hline 8 & Sapucaí/Grande & Estreito, Jaguara \\
\hline 9 & Mogi Guaçu & Euclides da Cunha,Limoeiro \\
\hline 10 & Tietê/Sorocaba & represa de Itupararanga \\
\hline 11 & Ribeira de Iguape e Litoral Sul & $\begin{array}{c}\text { França, Fumaça, Barra,Porto Raso, } \\
\text { Alecrim, Serraria }\end{array}$ \\
\hline 12 & Baixo Pardo/Grande & Volta Grande, Porto Colombia \\
\hline 13 & Tietê/Jacaré & Barra Bonita, Bariri, Ibitinga,Lobo/Broa \\
\hline 14 & Alto Paranapanema & Pirajui, Jurumrim \\
\hline 15 & Turvo/Grande & Marimbondo, Agua Vermelha,Turvo \\
\hline 16 & Tietê/Batalha & Promissão \\
\hline 17 & Médio Paranapanema & Capivara, Xavantes \\
\hline 18 & São Jose'dos Dourados & Jupiá,Ilha Solteira \\
\hline 19 & Baixo Tietê & Nova Avanhandava, Três Imãos \\
\hline 20 & Aguapeí & Porto Primavera \\
\hline 21 & Peixe & Boa Esperança \\
\hline 22 & $\begin{array}{l}\text { Baixo ou Pontal do } \\
\text { Paranapanema }\end{array}$ & Taquaruçu, Rosana \\
\hline
\end{tabular}


In 1998 a large Project on Biodiversity in Sa o Paulo State was caried out financed by FAPESP (BIOTA/FAPESP) Matsumura-Tund isi, 2003, covering both terrestrial and aquatic organisms, a imed to explore the maximum biodiversity and to know the geographical distribution of the orga nisms through the construction of the maps using GPS. In the c a se of a quatic orga nisms, specific ally zooplankton community 330 water bodies were studied including, small lakes, resenoirs, rivers, in such a way that in each UGRHi we have explored among 10 to 15 water bodies.

\section{Material and Methods}

The Calanoida specimens were obtained through a standard net sampling

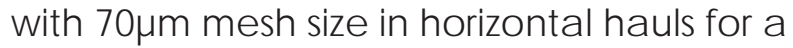
shallow water bodies and vertical hauls for deep water. In both cases the filtered water in the net was around 1 thousand liters. All the sampling sites were determined with GPS and after the analysis of the material at the laboratory identifying the Calanoida copepods at the level of species the metadata was sent to SinBiota (Instituto de Biodiversidade) to processing and producing the distribution map of Calanoida species at the 22 UGRHi of Sã o Paulo Sta te

\section{Results}

In the study of 250 water bodies (including small standing waters, rivers, la rge reservoirs), and 398 samplings carried out in São Paulo State, it was identified 12 species of Calanoida, one of them a new species described by Matsumura-Tund isi et al., 2010.
They a re: Argyro dia pto mus furc a tus (SARS, 1901), Argyrodia ptomus azeved oi (WRIG HT, 1935), Noto dia ptomus ihering i (WRIG HT, 1935), Notodia ptomus cea rensis (WRIG HT, 1936) Notodiaptomus henseni (DAHL, 1894), Notodia ptomus venezola nus deevoyorum (BOWMAN, 1973), Notodia ptomus sp inuliferus (DUSSART, MATSUMURA-TUNDISI, 1986; MATSUMURA-TUNDISI, 2008), Notodia ptomus deitersi (POPPE, 1891), Notodia ptomus oliveirai (MATSUMURA-TUNDISI, et al., 2015), O donto dia pto mus pa ulista nus (WRIG HT, 1936), Pseud odia ptomus ric ha rd i (DAHL, 1894), Sc olodia pto mus corderoi (WRIG HT, 1936).

\section{Geographical distribution of species}

\section{Argyrodiaptomus furcatus}

This species (Figure 1a) was more frequent in the UGRHi of the northeast side of São Paulo State ascan be seen in the Figure 1b.

The specieswere found ma inly on the reservoirs of the following UGRHi: Sapucai/ Grande (8); Pardo (4); Mogi Guaçu (9); Tetê/Sorocaba (10); Pira cicaba/Capivi/ J undiai (5); Tietê/J aca ré (13); Alto Tietê (6); Paraiba do Sul (2) and in some reservoirs of River Paranapa nema.

Argyrodiaptous furcatus was the only Calanoida speciespresent in the Lobo/Broa reservoir (UGRHi-13). 


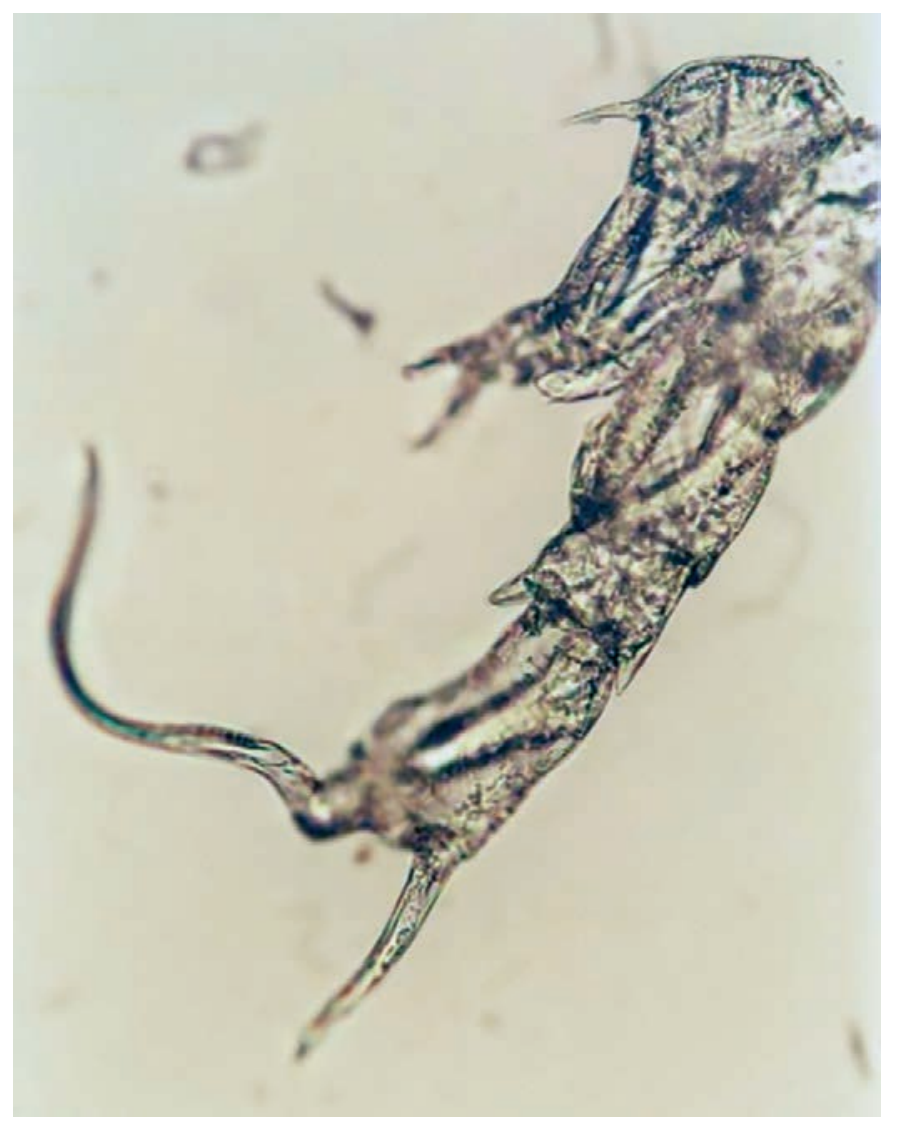

Figure $1 \mathrm{a}-$ Characteristics of $5^{\text {th }}$ leg of male of Argyrodiaptomus furcatus.

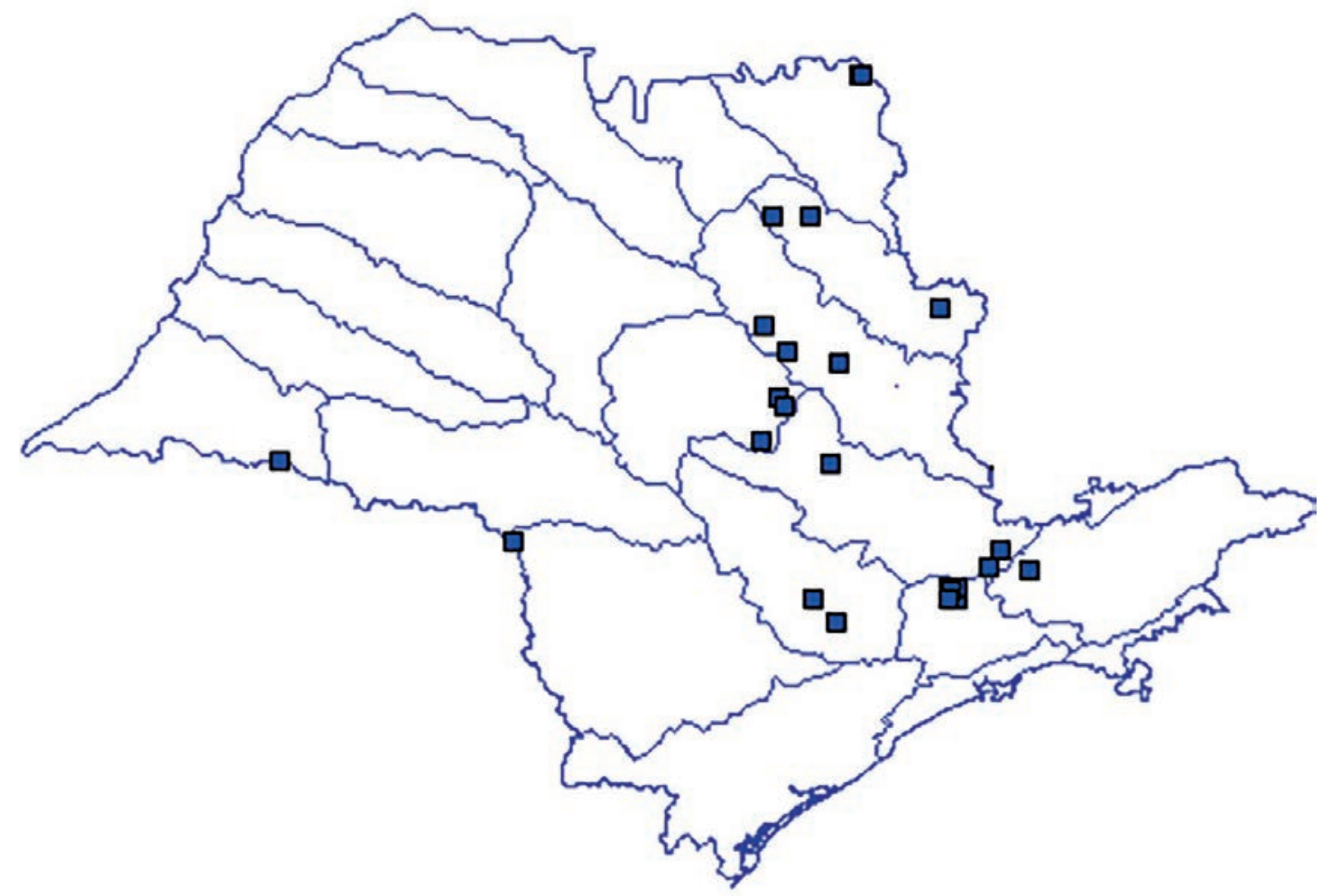

Figure 1b-Map of geographical distribution of Argyrodiaptous furcatus (SinBiota/FAPESP). 


\section{Argyrodiaptomus \\ azevedo ${ }^{2}$}

This species (Figure 2a) is restricted in the UGRHi that rec eive influence of River Paraná. They occurred in the following
Unities located at the west part of the São Paulo State: São J osé dos Dourados (18); Ba ixo Tietê (19); Tietê/ Batalha (16); Aguapei (20). Figure $2 \mathrm{~b}$ shows the geographical distribution of this species in water boies os São Paulo State.

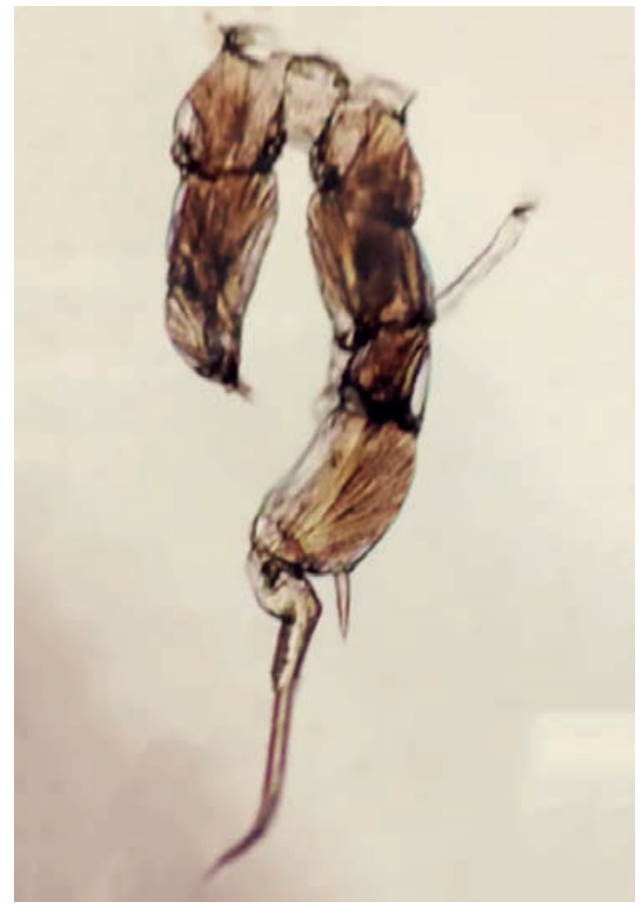

Figure $2 \mathrm{a}-$ Characteristics of $5^{\text {th }}$ leg of male Argyrodiaptomus azevedoi.

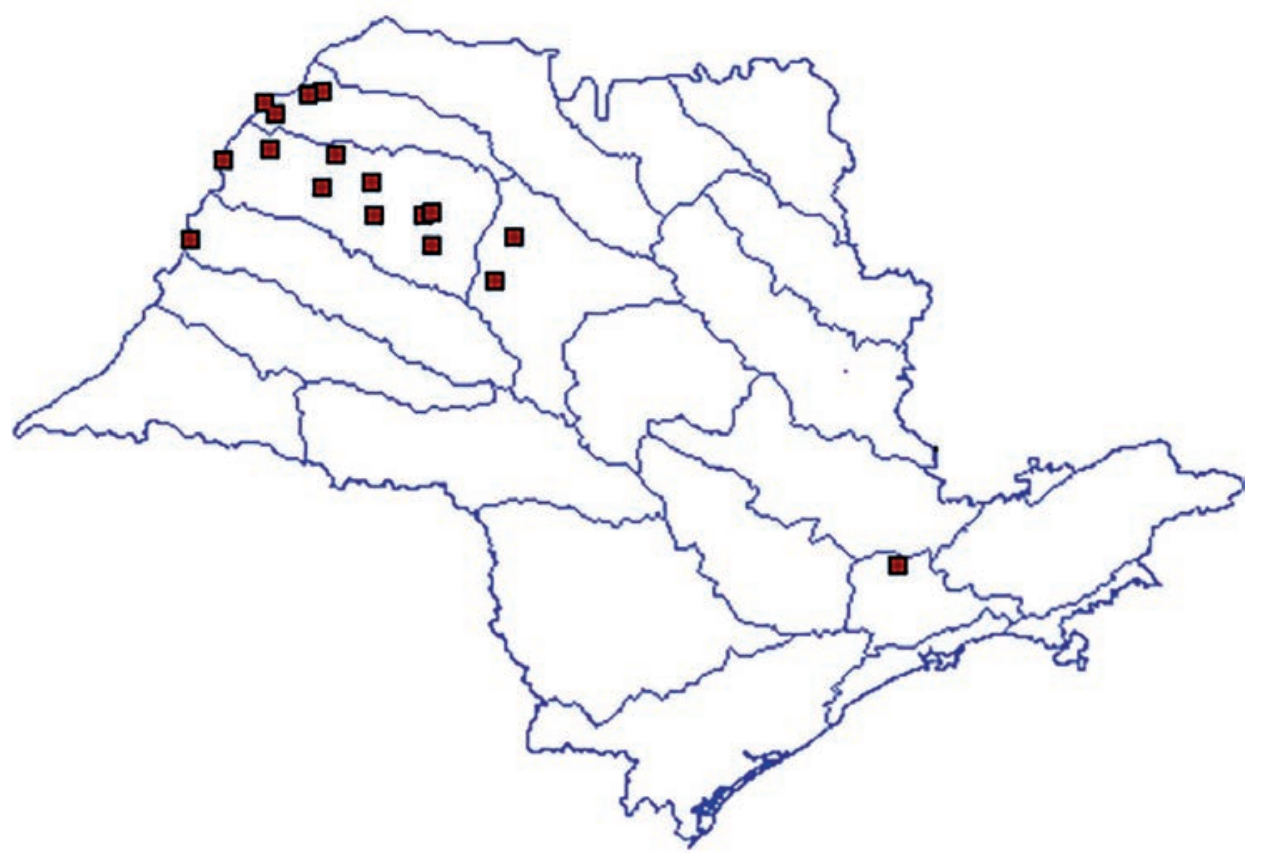

Figure $\mathbf{2 b}$ - Map of geographical distribution of Argyrodiaptous azevedoi (SinBiota/ FAPESP). 
3. Notodiaptomus

\section{iheringi}

This species (Figure 3a) described by Wright, 1935 from the material coming from the northeast part of Brazil, probably dispersed to the South part at São Paulo
State as has been stated Sendacz, Kubo, 1982 and Matsumura-Tund isi, Tundisi, 2003.

Currently as can be seen in the Figure $3 b$, the species a re largely distributed occuming in the most UGRHi of São Paulo State, showing that the species has a strong plasticity supporting a great habitat va ria bility.

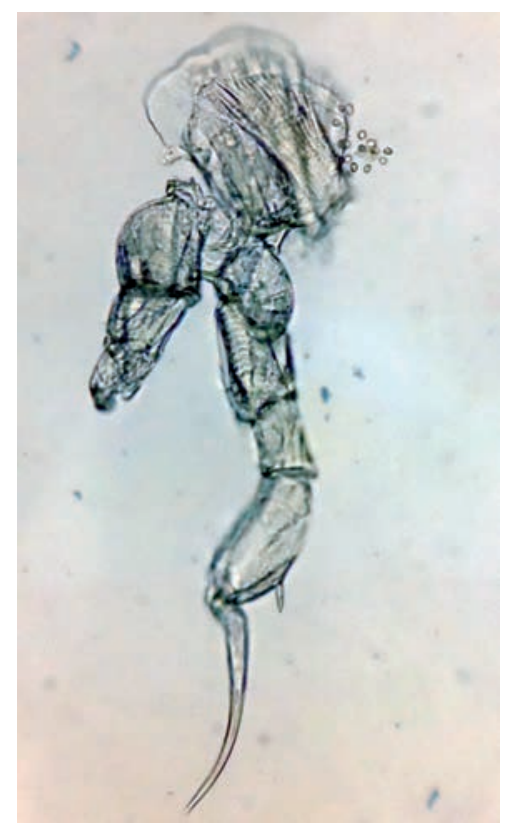

Figure $3 a-C h a r a c t e r i s t i c s$ of $5^{\text {th }}$ leg of male of Notodiaptomus iheringi

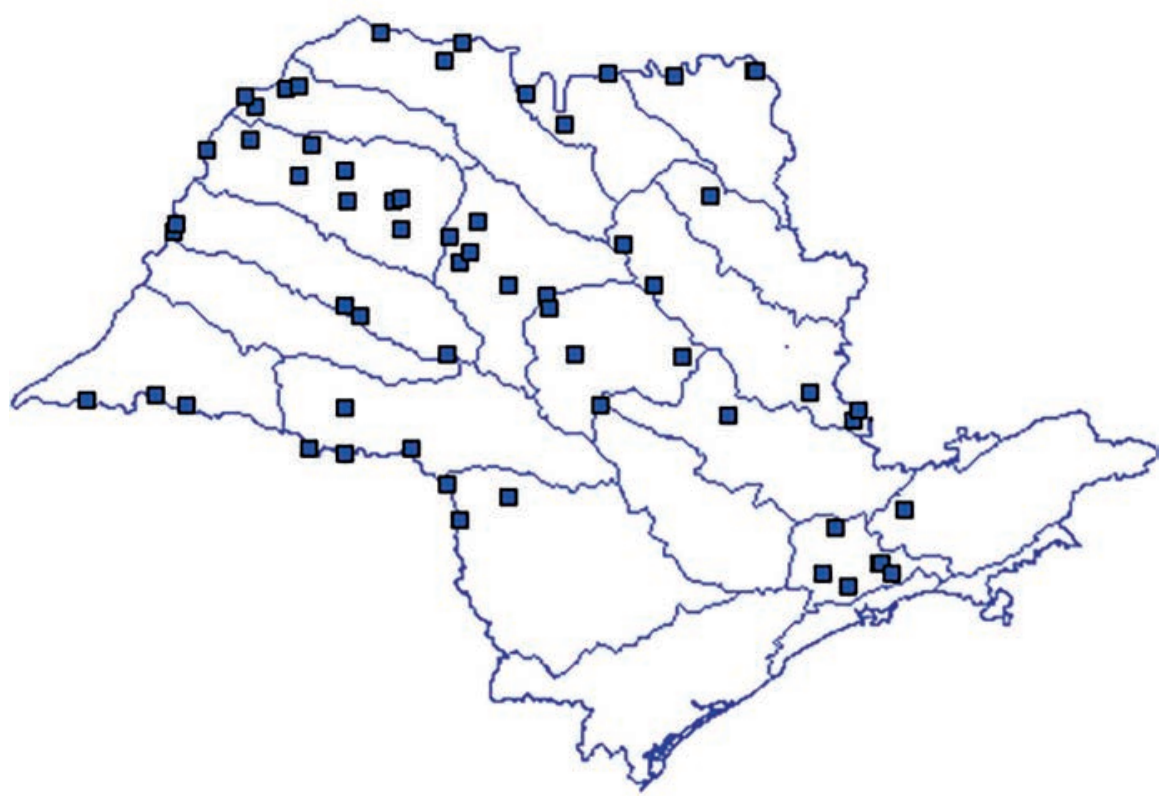

Figure 3b - Map of geographical distribution of Notodiaptomus iheringi in São Paulo State (SinBiota/FAPESP). 


\section{Notodiaptomus}

\section{cearens is}

The species (Figure 4a) is very similar larger than the last one, and also coming to Notodiaptomus iheningi, however is more from the northeast part of Brazil.

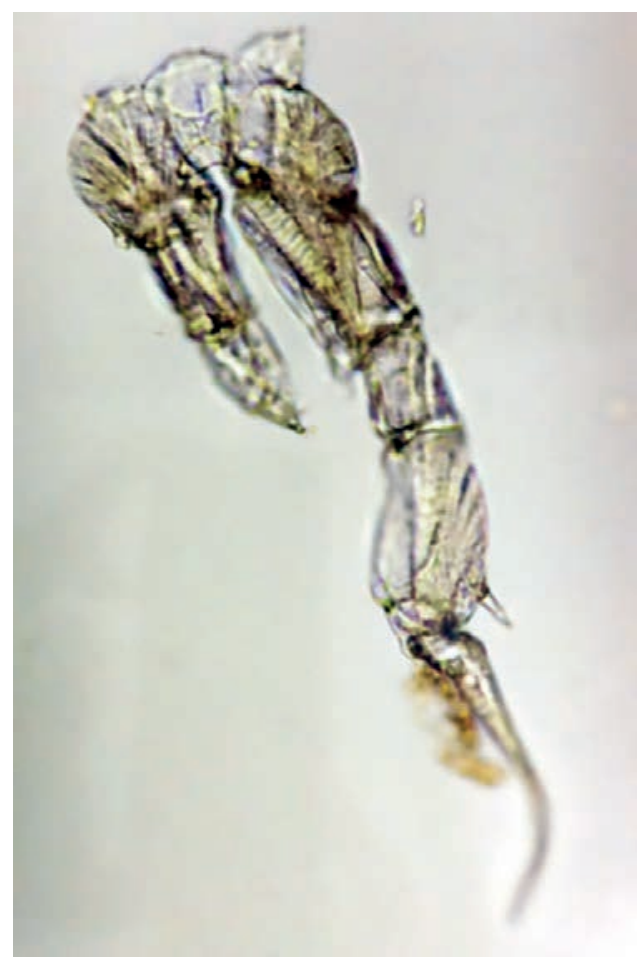

Figure $4 \mathrm{a}-$ Characteristics of $5^{\text {th }}$ leg of male of Notodiaptomus cearensis. Probably the species is coming from lower latitudes at northeast of Brazil.

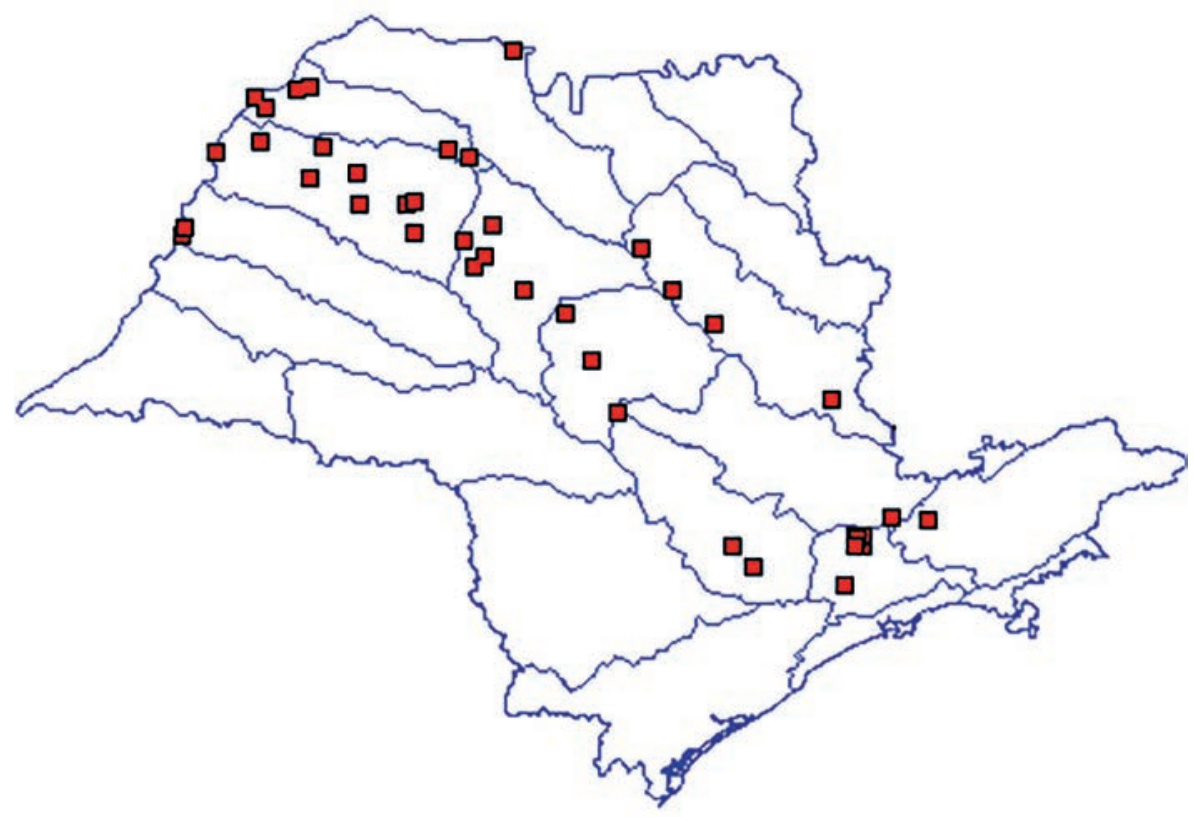

Figure $4 b-$ Map of geographical distribution of Notodiaptomus iheringi in São Paulo State (SinBiota/FAPESP). 
5. Notodiaptomus

\section{oliveirai}

Notodiaptomus oliveirai was observed at the first time in 1992-1993 in Ba rra Bonita reservoir by Espindola, 1994 as Notodiaptomus $\mathrm{n}$ sp. Furtheremore
Matsumura-Tundisi et al., 2010 described as Notodia ptomus oliveira i (Figure $5 a$ ). Recently the speciesbecame the most abundant population of Barra Bonita reservoir dispersing also in the other water bodies belonging at 22 UG RH of São Paulo State ascan be seen in the Figure $5 b$.

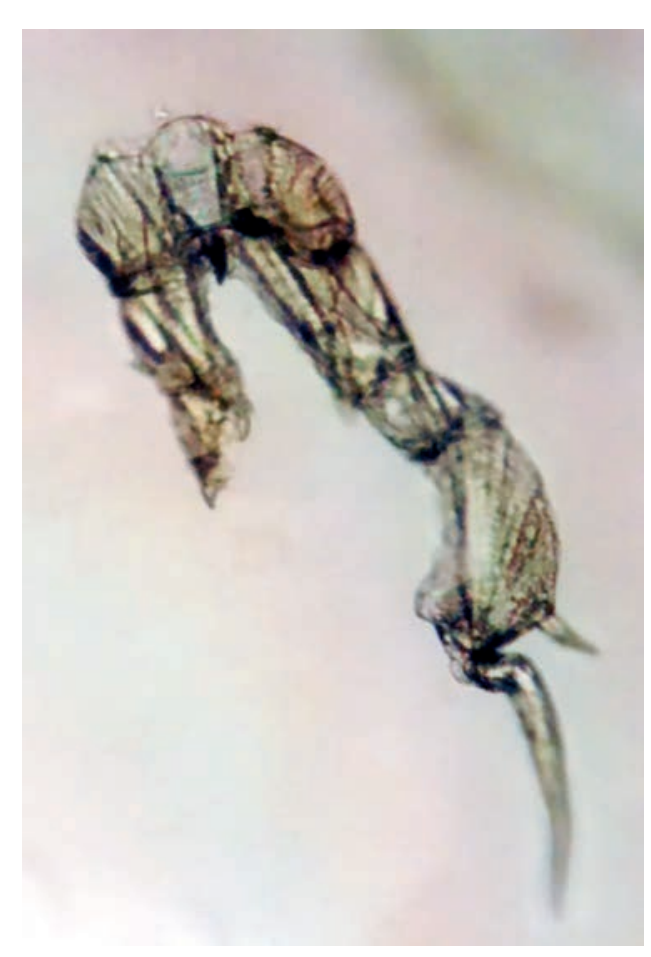

Figure $5 \mathrm{a}-$ Characteristics of $5^{\text {th }}$ leg of male of Notodiaptomus oliverai.

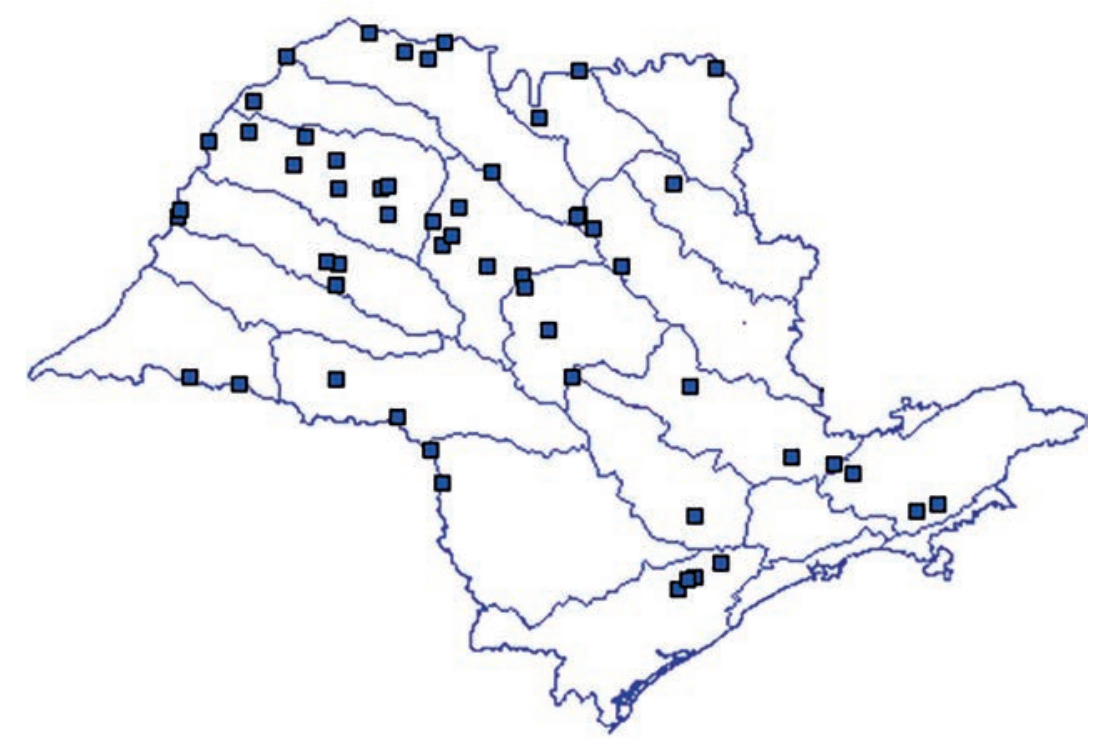

Figure 5b - Map of geographical distribution of Notodiaptomus oliveirai in São Paulo State (SinBiota/FAPESP). 


\section{Odontodiaptomus pautistanus}

This species (Figure 6a) described by Wright (1935) from the material collected in the water bodies of UG RH-Alto Tietê, never have been registered in other places of São
Paulo State. At present study it has been registered only in UGRH Alto Tietê in the following resenoirs: Ribeirão do Campo,, Billings, Ponte Nova and Paiva Castro and in some lakes from UGRH 7 - Ba ixa da Santista ascan be seen in the Figure $6 \mathrm{~b}$.

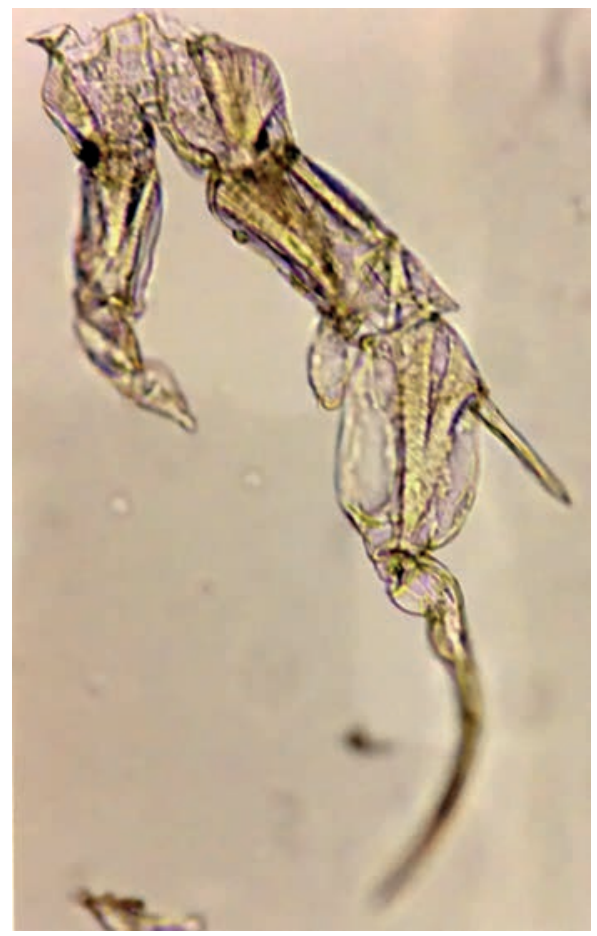

Figure $6 \mathrm{a}-$ Characteristics of $5^{\text {th }}$ leg of male of Odontodiaptomus paulistanus.

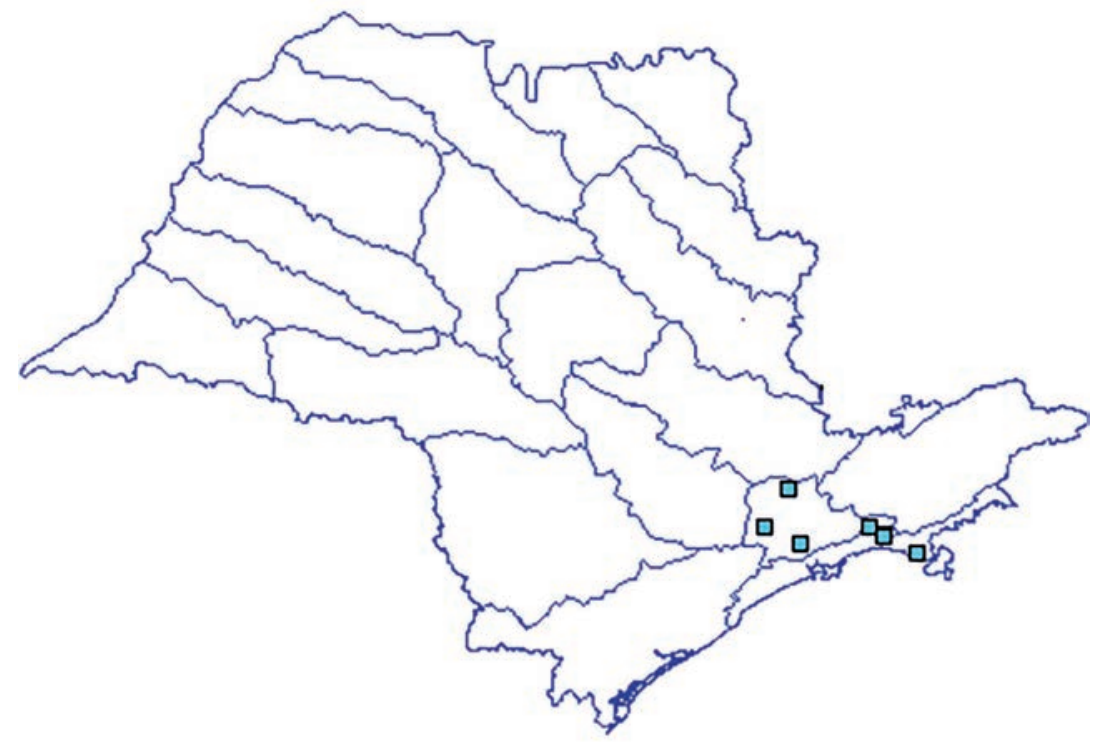

Figure $\mathbf{6 b}$ - Map of geographical distribution of Odontodiaptomus paulistanus in São Paulo State (SinBiota/FAPESP). 


\section{Notodiaptomus hensen ${ }^{\circ}$}

This species (Figure 7a) described by Dahl, 1891 from the material coming from Amazon it has been registered by the other a uthors such as Cipolli, Carva lho (1973) in the waters of Pará State, Matsumura-Tundisi in the lake J osé Maria (0330'S lat. 40 W long).

The present study shows that the species there was restricted in the water of low latitudes it was introduced in some way to the water of more high latitudes

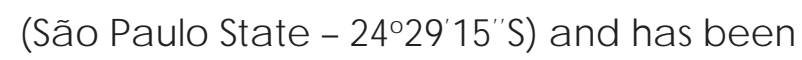
adapted very well a new habitat enlarged their distribution in São Paulo Sta te occuring in 13 UG RHi (Table 2).

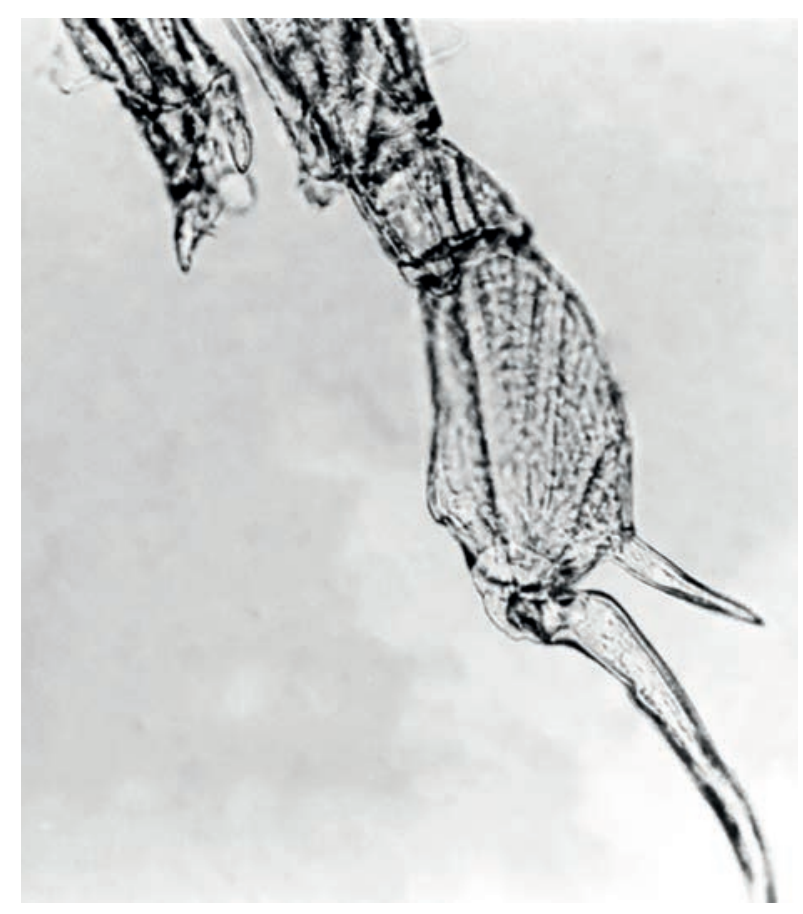

Figure $7 a-$ Characteristics of $5^{\text {th }}$ leg of male of Notodiaptomus henseni.

Table 2 - Occurrence of Notodiaptomus henseni in the lakes and reservoirs of 13 UGRHi of São Paulo State.

\begin{tabular}{ccc}
\hline No UGRHi & Name & Lakes \& Reservoirs \\
\hline 2 & Paraiba do Sul & Paraibuna \\
\hline 4 & Pardo & Graminha \\
\hline 5 & Piracicaba/Capivara/Jundiai & Paramirim,Atibainha \\
\hline 6 & Alto Tietê & Aguas Claras, Taiaçupeba, Jundiai \\
\hline 8 & Sapucaí/Grande & Jaguara, Sapucai, Igarapava, \\
& Volta Grande \\
\hline 10 & Tietê/Sorocaba & Itupararanga \\
\hline 11 & Ribeira do Iguape/Litoral Sul & Serraria,Alecrim, Cachoeira da França \\
\hline 15 & Turvo/Grande & Fumaça, Barra \\
\hline 16 & Tietê/Batalha & Ibitinga, Bariri \\
\hline 17 & Médio Paranapanema & Capivara \\
\hline 18 & São José dos Dourados & Ilha Solteira,lagoa Estancia Semax \\
\hline 19 & Baixo Tietê & Três Irmãos,Jupiá \\
\hline 20 & Aguapeí & lago Country Clube(Rio Aguapeí), \\
\hline & lago Pinopolis, lagoa Central (Rio Paraná) \\
\hline
\end{tabular}




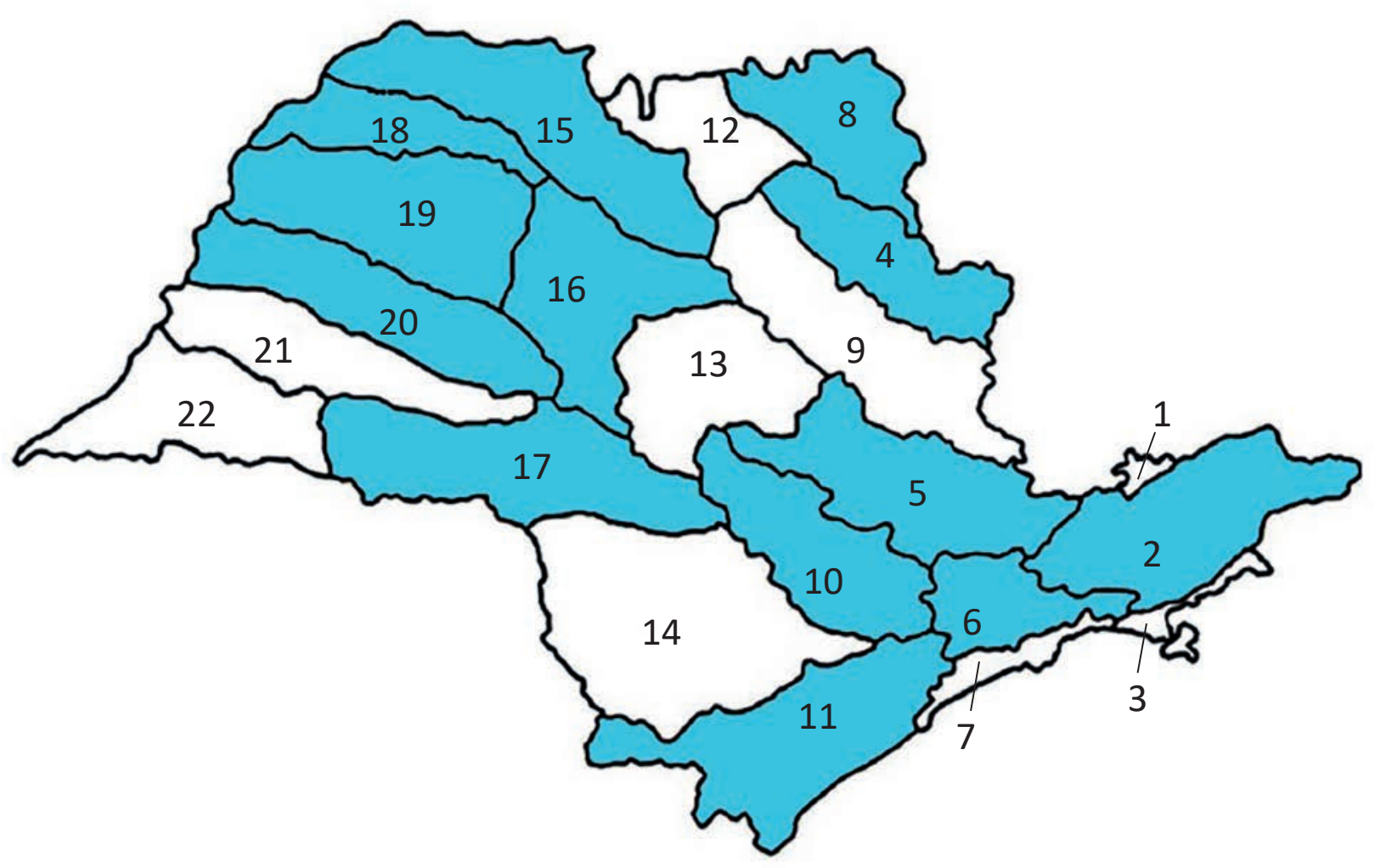

\section{Unidades de Gerenciamento de Recursos Hídricos - UGRHi}

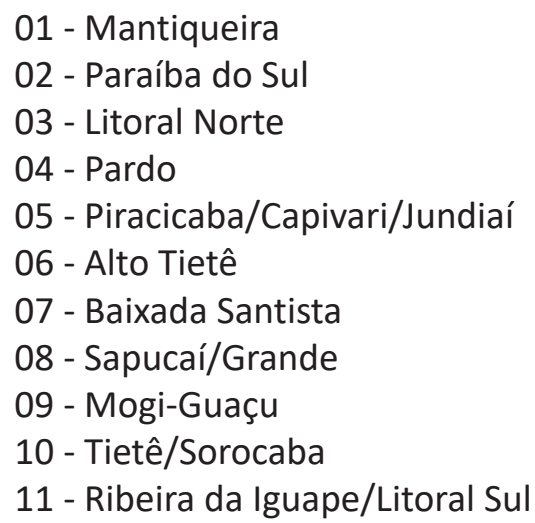

12 - Baixo Pardo/Grande

13 - Tietê/Jacaré

14 - Alto do Paranapanema

15 - Turvo/Grande

16 - Tietê/Batalha

17 - Médio Paranapanema

18 - São José dos Dourados

19 - Baixo Tietê

20 - Aguapeí

21 - Peixe

22 - Pontal do Paranapanema

Figure 7b - Map of geographical distribution of Notodiaptomus henseni in São Paulo State. 


\section{Notodiaptomus deitersi}

This species (Figure 8a) was rec orded in the lakes of Pantanal Matogrossense (Recreio, Sá Mariana) located at 16¹1'39"S lat. and 56 $14^{\prime} 45^{\prime \prime}$ W long. (MATSUMURATUNDISI, 1986).

In the present work it was recorded only at three URG Hi of São Paulo State (Alto Tietê, Tietê/J acaré and Ribeira do Iguape/ Litoral Sul) (Table 3).

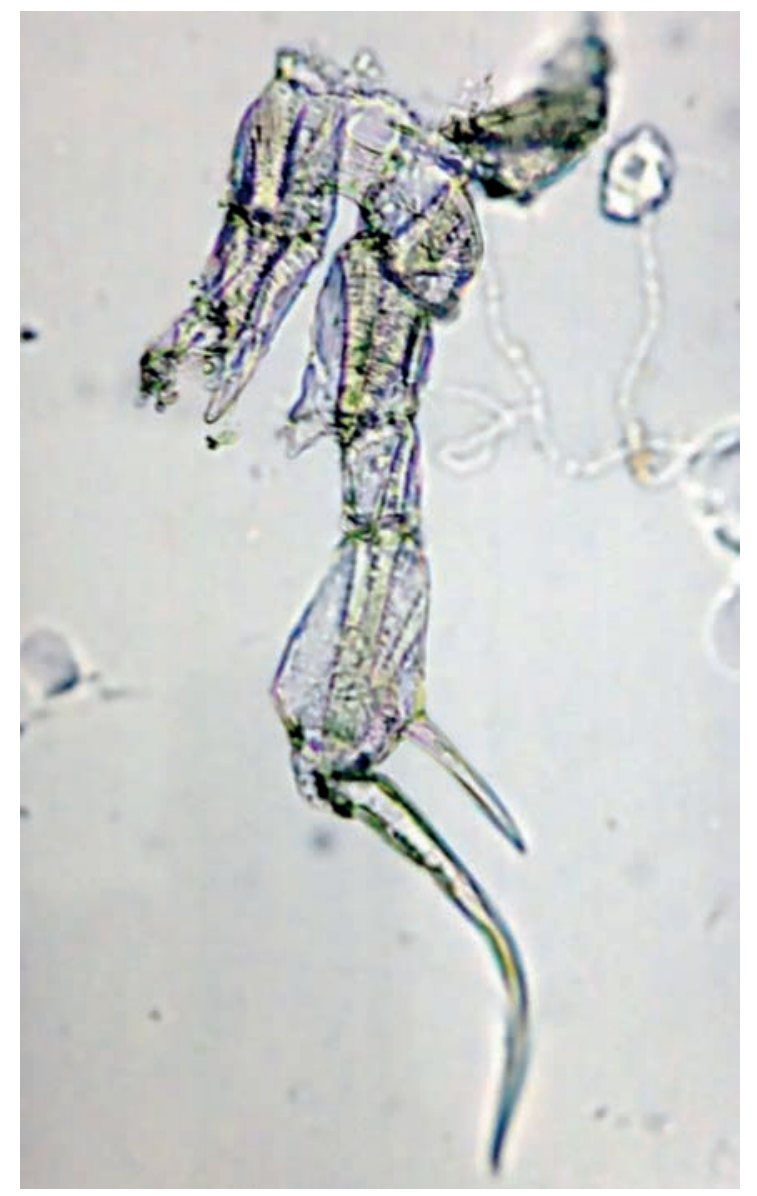

Figure $8 \mathrm{a}-$ Characteristics of $5^{\text {th }}$ leg of male of Notodiaptomus deitersi.

Table 3 - Occurrence of Notodiaptomus deitersi in the lakes and reservoirs of 3 UGRHi of São Paulo State.

\begin{tabular}{|c|c|c|}
\hline No UGRHi & Name & Lakes \& Reservoirs \\
\hline 6 & Alto Tietê & Paiva Castro \\
\hline 13 & Tietê /Jacaré & Ibitinga \\
\hline 11 & Ribieira do Iguape/Litoral Sul & Porto Raso, Barra \\
\hline
\end{tabular}




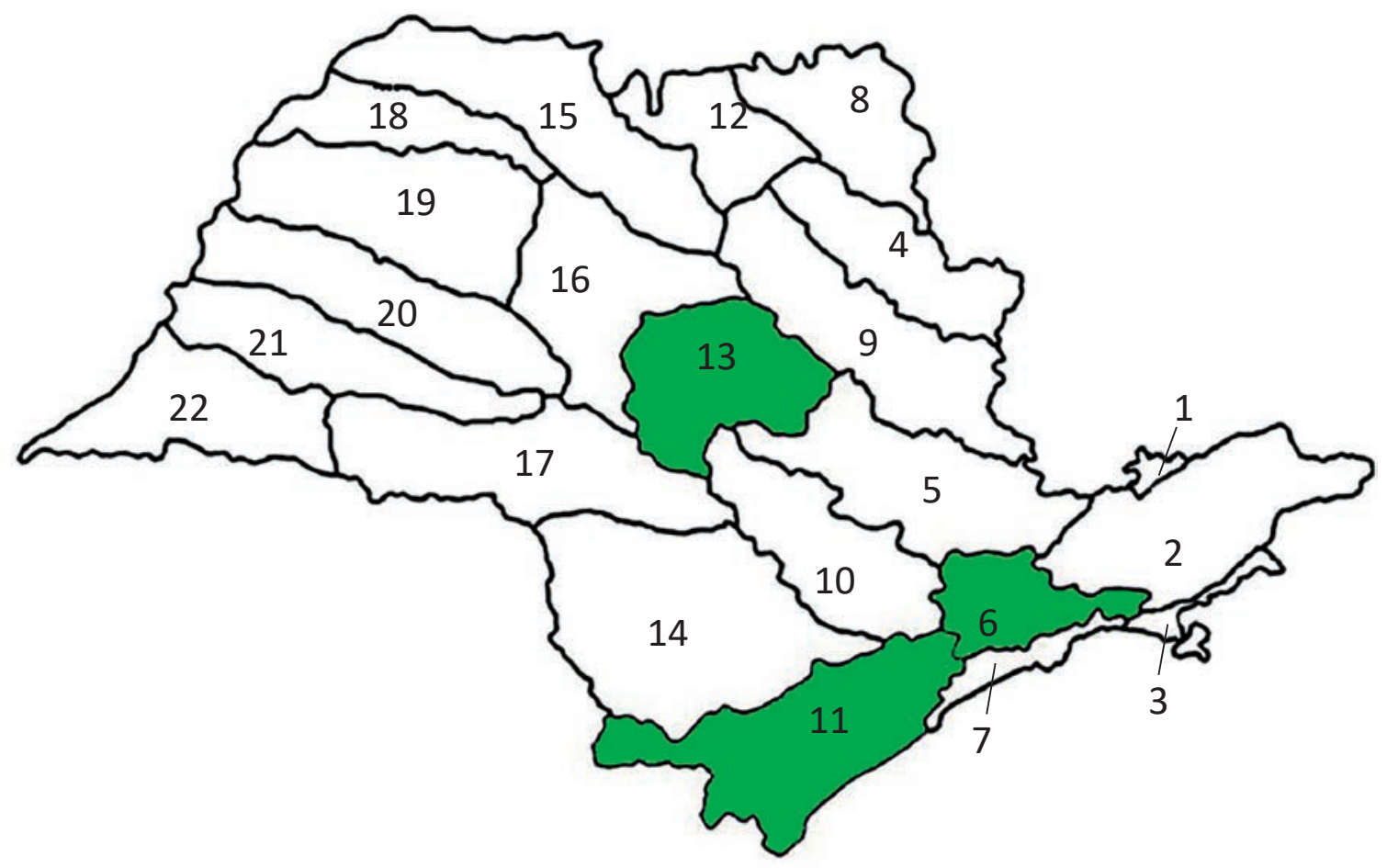

Unidades de Gerenciamento de Recursos Hídricos - UGRHi

01 - Mantiqueira
02 - Paraíba do Sul
03 - Litoral Norte
04 - Pardo
05 - Piracicaba/Capivari/Jundiaí
06 - Alto Tietê
07 - Baixada Santista
08 - Sapucaí/Grande
09 - Mogi-Guaçu
10 - Tietê/Sorocaba
11 - Ribeira da Iguape/Litoral Sul

12 - Baixo Pardo/Grande

13 - Tietê/Jacaré

14 - Alto Paranapanema

15 - Turvo/Grande

16 - Tietê/Batalha

17 - Médio Paranapanema

18 - São José dos Dourados

19 - Baixo Tietê

20 - Aguapeí

21 - Peixe

22 - Pontal do Paranapanema

Figure $\mathbf{8 b}$ - Map of geographical distribution of Notodiaptomus deitersi in São Paulo State.

\section{Notodiaptomus \\ spinutiferus}

This Cala noida was found at the first time in the sampling camied out in llha Solteira resenoir (UG RHi-18, São J osé dos Dourados) during the process of the Project "Typology of reservoirs of São Paulo State" and described as a new species by Dussart,
Matsumra-Tundisi,1986 and ca mied out for rectific a tion by Matsumura-Tundisi, 2008. In the present study it was observed that the species enlarged its occurrence occupying lakes and reservoirs from 9 UG RHi of São Paulo State asca be seen in the Table 4.

Figure $9 \mathrm{~b}$ shows the map of geographical distribution of Notodiaptomus sp inuliferus in the waters of São Paulo State. 


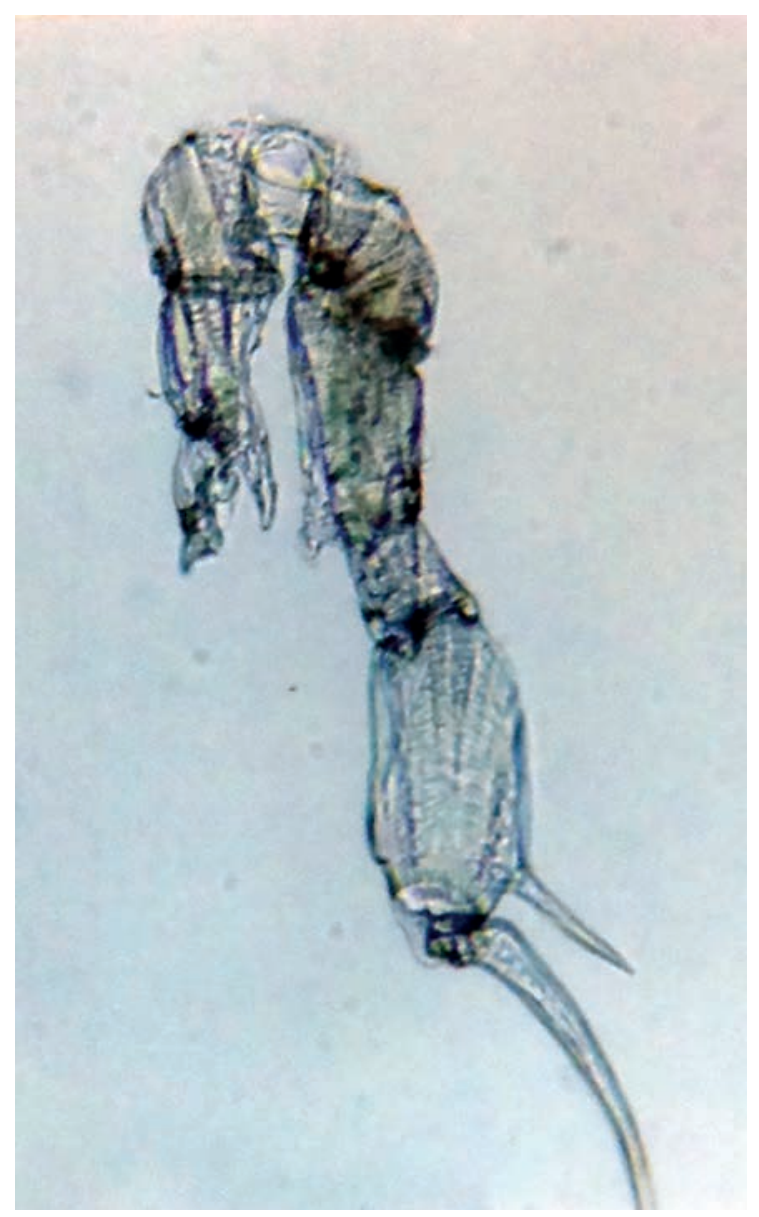

Figure $9 \mathrm{a}-$ Characteristics of $5^{\text {th }}$ leg of male of Notodiaptomus spinuliferus.

Table 4 - Occurrence of Notodiaptomus spinuliferus in the lakes and reservoirs from 9 UGRHi of São Paulo State.

\begin{tabular}{ccc}
\hline No UGRHi & Name & Lakes \& Reservoirs \\
\hline 5 & Piracicaba/Capivara/Jundiai & Atibainha \\
\hline 10 & Tietê/Sorocaba & Itupararanga, Prainha, Hedberg \\
\hline 11 & Ribeira do Iguape/Litoral Sul & Jurupara \\
\hline 13 & Tietê/Jacaré & Cestari, Santa Ana \\
\hline 15 & Turvo/Grande & Taquaruçu, Capivara \\
\hline 16 & Tietê/Batalha & Lago Laranja Azeda (Ibitinga), Bariri, Promissão \\
\hline 17 & Médio Paranapanema & Lagoas: Pau da Onça, Marreco \\
\hline 20 & Aguapeí & Rosana \\
\hline 22 & Baixo(Pontal) Paranapanema & \\
\hline
\end{tabular}




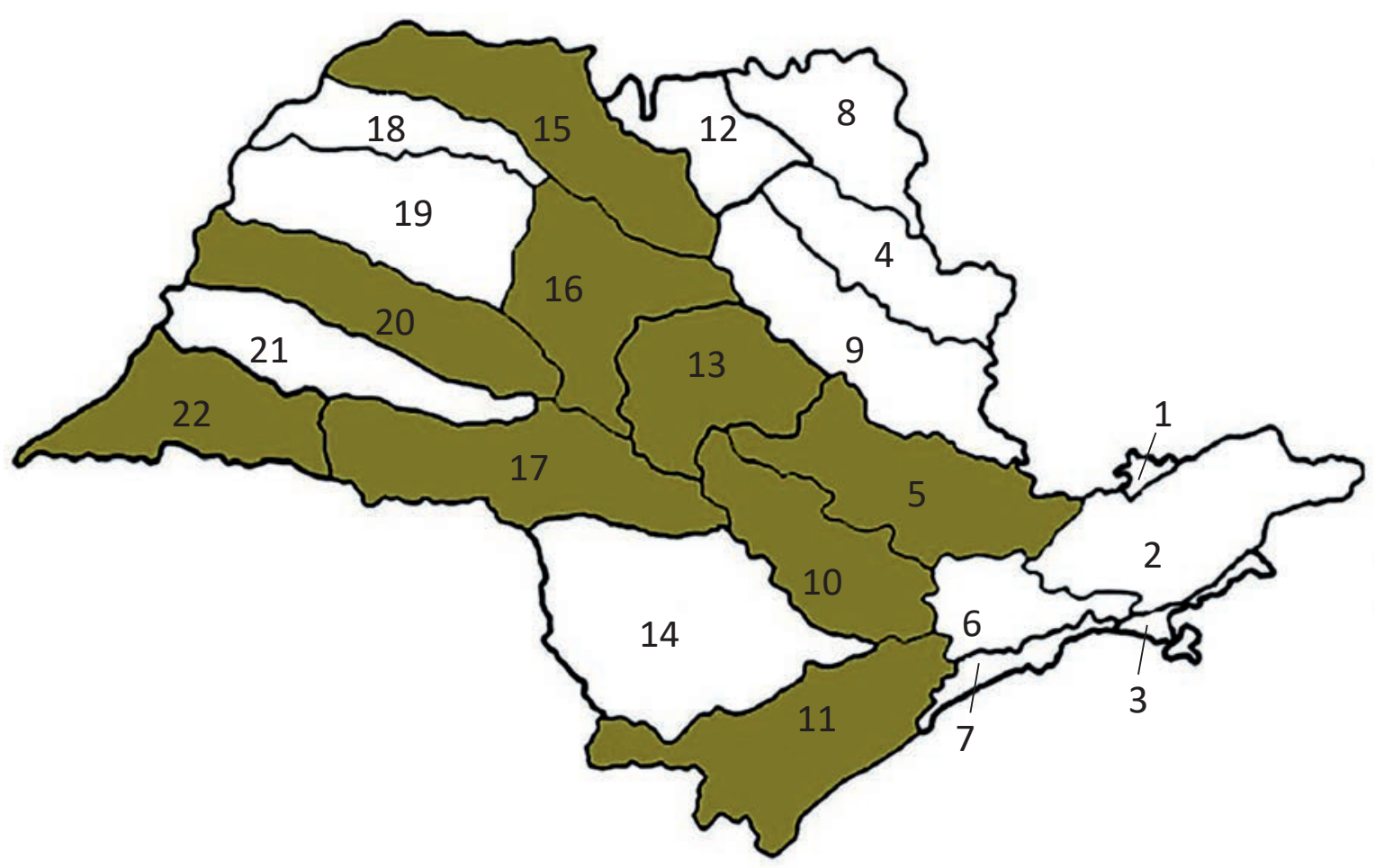

\section{Unidades de Gerenciamento de Recursos Hídricos - UGRHi}

01 - Mantiqueira

02 - Paraíba do Sul

03 - Litoral Norte

04 - Pardo

05 - Piracicaba/Capivari/Jundiaí

06 - Alto Tietê

07 - Baixada Santista

08 - Sapucaí/Grande

09 - Mogi-Guaçu

10 - Tietê/Sorocaba

11 - Ribeira da Iguape/Litoral Sul
12 - Baixo Pardo/Grande

13 - Tietê/Jacaré

14 - Alto Paranapanema

15 - Turvo/Grande

16 - Tietê/Batalha

17 - Médio Paranapanema

18 - São José dos Dourados

19 - Baixo Tietê

20 - Aguapeí

21 - Peixe

22 - Pontal do Paranapanema

Figure 9b - Map of geographical distribution of Notodiaptomus spinuliferus in São Paulo State.

\section{Notodiaptomus}

\section{venezoetanus deevoyorum}

The species (Figure 10) described by Kiefer, 1956 from the material collected from the lakes of Venezuela, it was recorded at the first time in Brazil in the lakes of Pantanal Matogrossense (Sá Mariana, Chacororé, Buritizal) by Ma tsumura-Tundisi, 1986.
In the present investigation this species occurred I the la kes and reservoirs of São Paulo State at $24^{\circ} 29^{\prime} 15^{\prime \prime}$ S showing a large geographic al distribution occupaying 8 UG RHi of São Paulo State (Table 4).

Figure 10b shows the map of geographic al distribution of Notodia ptomus venezoelanus deevoyorum ocupaying 8 UG RHi of Sã o Paulo State. 


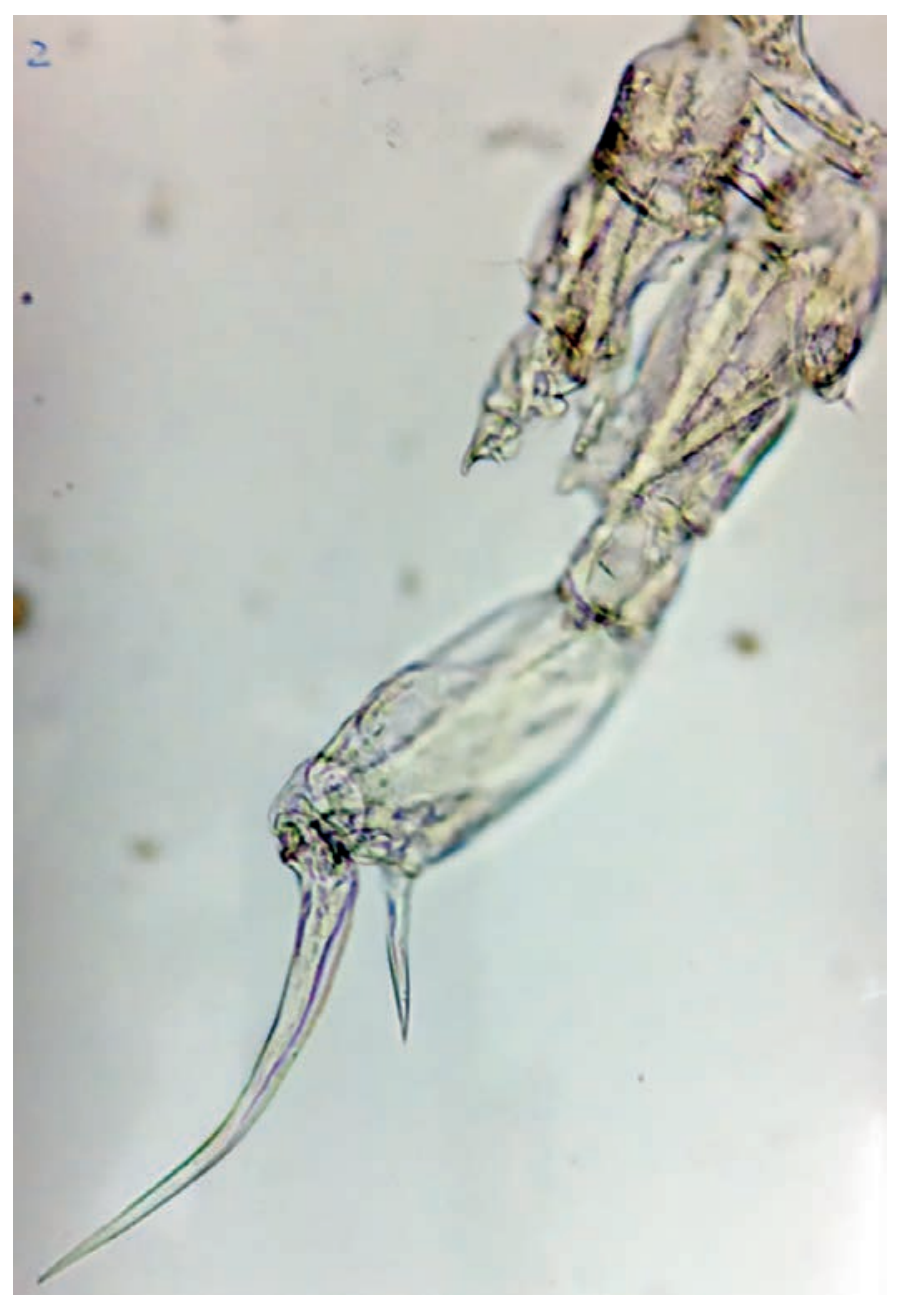

Figure 10a-Characteristics of $5^{\text {th }}$ leg of male of Notodiaptomus venezoelanus deevoyorum.

Table 5 - Occurrence of Notodiaptomus venezoelanus deevoyorum in the lakes and reservoirs from 8 UGRHi of São Paulo State.

\begin{tabular}{ccc}
\hline No UGRHi & Name & Lakes \& Reservoirs \\
\hline 5 & Piracicaba/Capivara/Jundiai & Igaratá \\
\hline 6 & Alto Tietê & Taiaçupeba \\
\hline 10 & Tietê/Sorocaba & Santa Branca, Paraibuna \\
\hline 11 & Ribeira do Iguape/Litoral Sul & Porto Raso, Serraria, Barra \\
\hline 15 & Turvo/Grande & Agua Vermelha \\
\hline 16 & Tietê/Batalha & lago Laranja Azeda (Ibitinga), Bariri \\
\hline 17 & Médio Paranapanema & Taquaruçu \\
\hline 18 & São José dos Dourados & Ilha Solteira \\
\hline
\end{tabular}




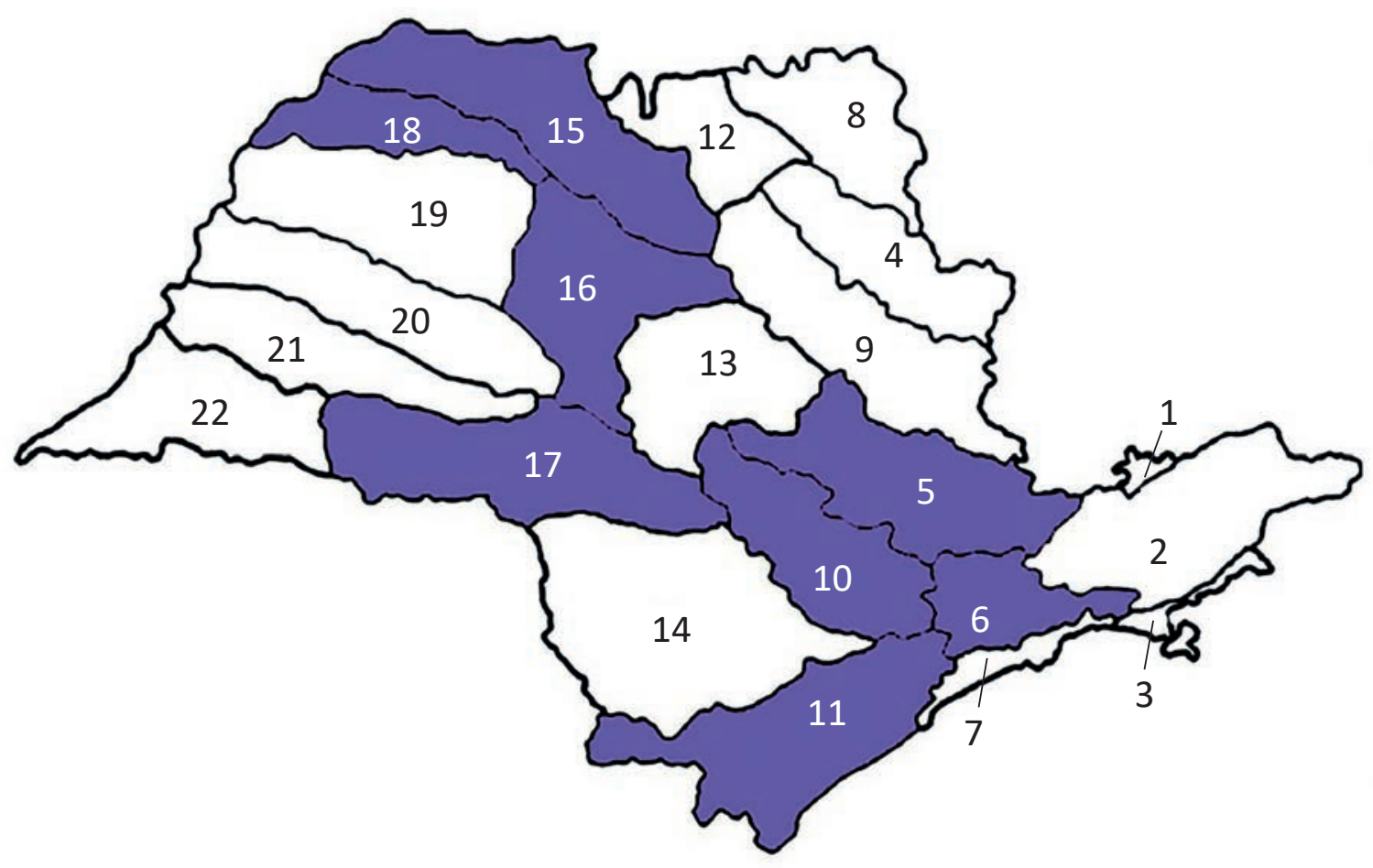

\section{Unidades de Gerenciamento de Recursos Hídricos - UGRHi}

01 - Mantiqueira
02 - Paraíba do Sul
03 - Litoral Norte
04 - Pardo
05 - Piracicaba/Capivari/Jundiaí
06 - Alto Tietê
07 - Baixada Santista
08 - Sapucaí/Grande
09 - Mogi-Guaçu
10 - Tietê/Sorocaba
11 - Ribeira da Iguape/Litoral Sul

12 - Baixo Pardo/Grande

13 - Tietê/Jacaré

14 - Alto Paranapanema

15 - Turvo/Grande

16 - Tietê/Batalha

17 - Médio Paranapanema

18 - São José dos Dourados

19 - Baixo Tietê

20 - Aguapeí

21 - Peixe

22 - Pontal do Paranapanema

Figure 10b-Map of geographical distribution of Notodiaptomus venezoelaus deevoyorum in São Paulo State.

\section{Scolodiaptomus corderoi}

In the samplings made in 1979 (Typology of reservoirs of São Paulo State - TUNDISI, 1980) this species (Figure 11a) was present in the most of reservoirs belonging in the River Paraná basin, Rio Grande River basin and Rio Pardo basin, in large quantity (MATSUMURATUNDISI, TUNDISI, 2003). However rec ent studies showed the complete disappearance of this spec ies from Barra Bonita reservoir that was present in abundance between 19831984 and from other reservoirs. The present data show the scarcity of Scolodiaptomus corderoi presence in the most waterbodies of São Paulo State ascan be seen in the table 6 occuming in some reservoirs from 4 (four) UG RHi: Mantiqueira, Pardo, Alto Tietê, Sapucai/Grande. 


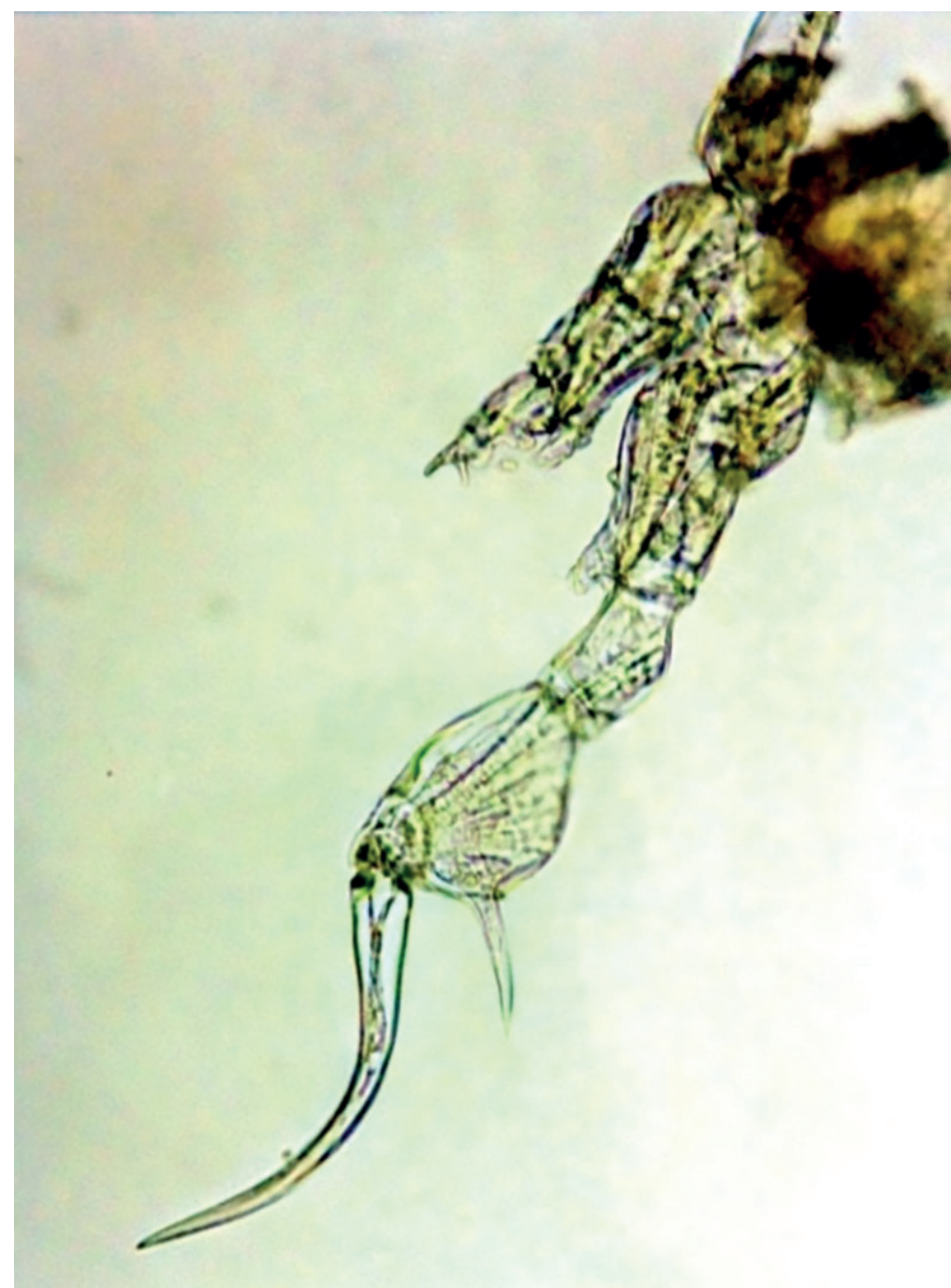

Figure 11a - Characteristics of $5^{\text {th }}$ leg of male of Solodiaptomus corderoi.

Table 6-Occurrence of Scolodiaptomus corderoi in the lakes and reservoirs from 4 UGRHi of São Paulo State.

\begin{tabular}{ccc}
\hline No UGRHi & Name & Lakes \& Reservoirs \\
\hline 1 & Mantiqueira & Lago das Ninfeas, Horto \\
\hline 4 & Pardo & Limoeiro \\
\hline 6 & Alto Tietê & Aguas Claras, Guarapiranga \\
\hline 8 & Sapuai/Grande & Jaguara, Volta Grande \\
\hline
\end{tabular}




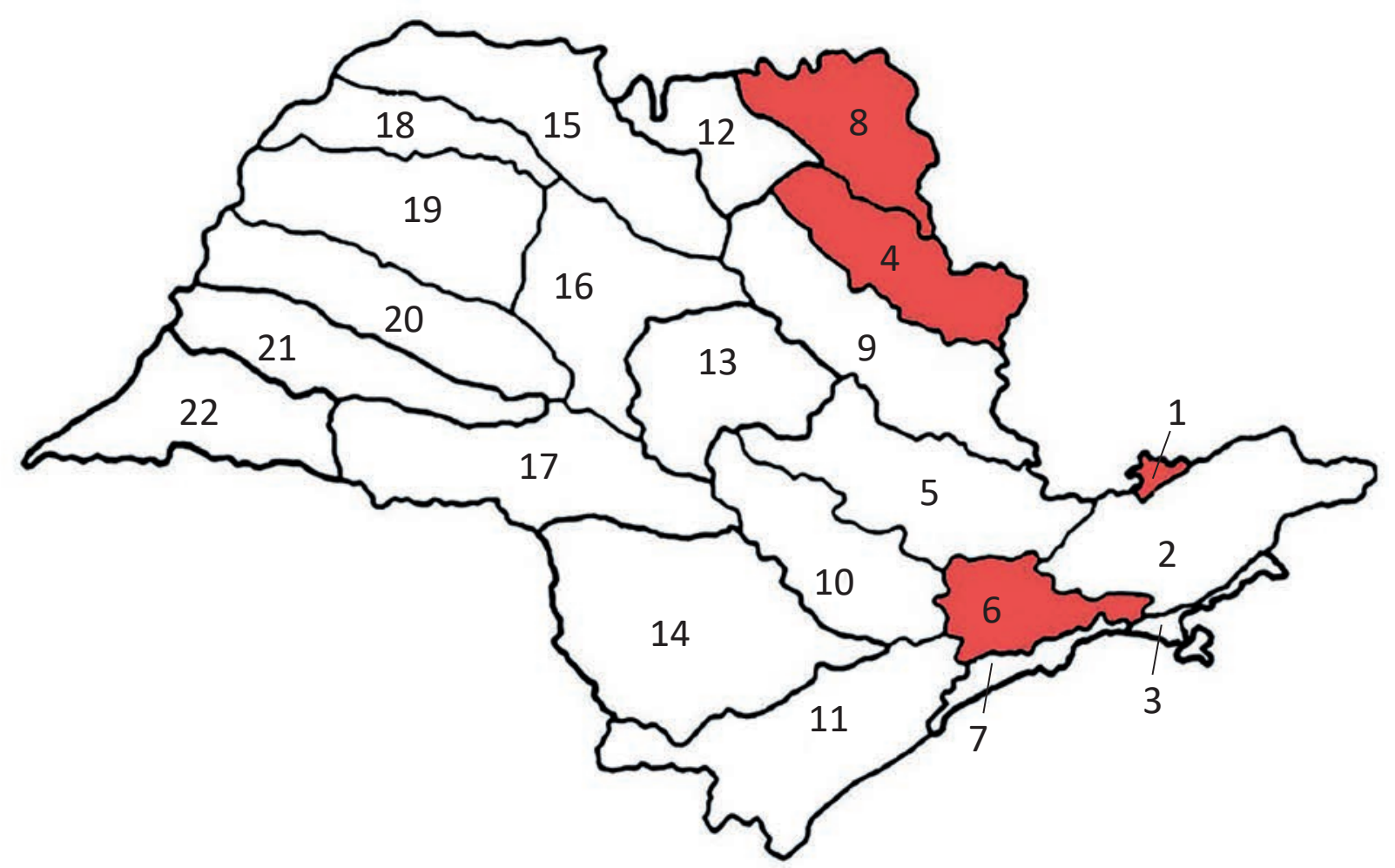

\section{Unidades de Gerenciamento de Recursos Hídricos - UGRHi}

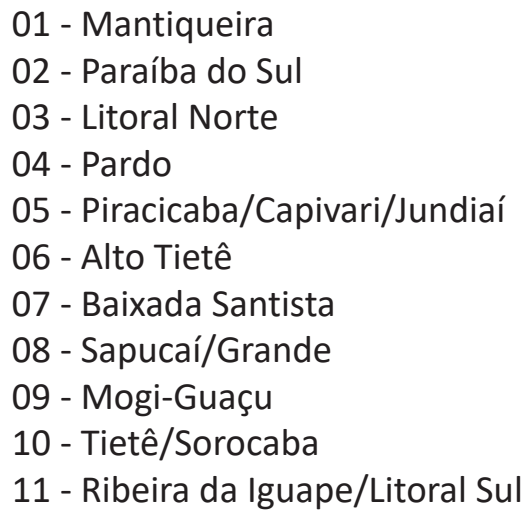

12 - Baixo Pardo/Grande

13 - Tietê/Jacaré

14 - Alto Paranapanema

15 - Turvo/Grande

16 - Tietê/Batalha

17 - Médio Paranapanema

18 - São José dos Dourados

19 - Baixo Tietê

20 - Aguapeí

21 - Peixe

22 - Pontal do Paranapanema

Figure 11b - Map of geographical distribution of Scolodiaptomus corderoi in São Paulo State.

\section{Pseudodiaptomus richardi}

This is a brackish water species (Figure 12a) found only in UG RHi 7 (Baixa da Santista) where the Rio Aguapei that flows to the Atlantic Ocean suffers the influence of the seas. Table 7 and Figure $12 \mathrm{~b}$ show the occurrence of Pseudodiaptomus ric hard only in the UGRHi Baixada Santista. 


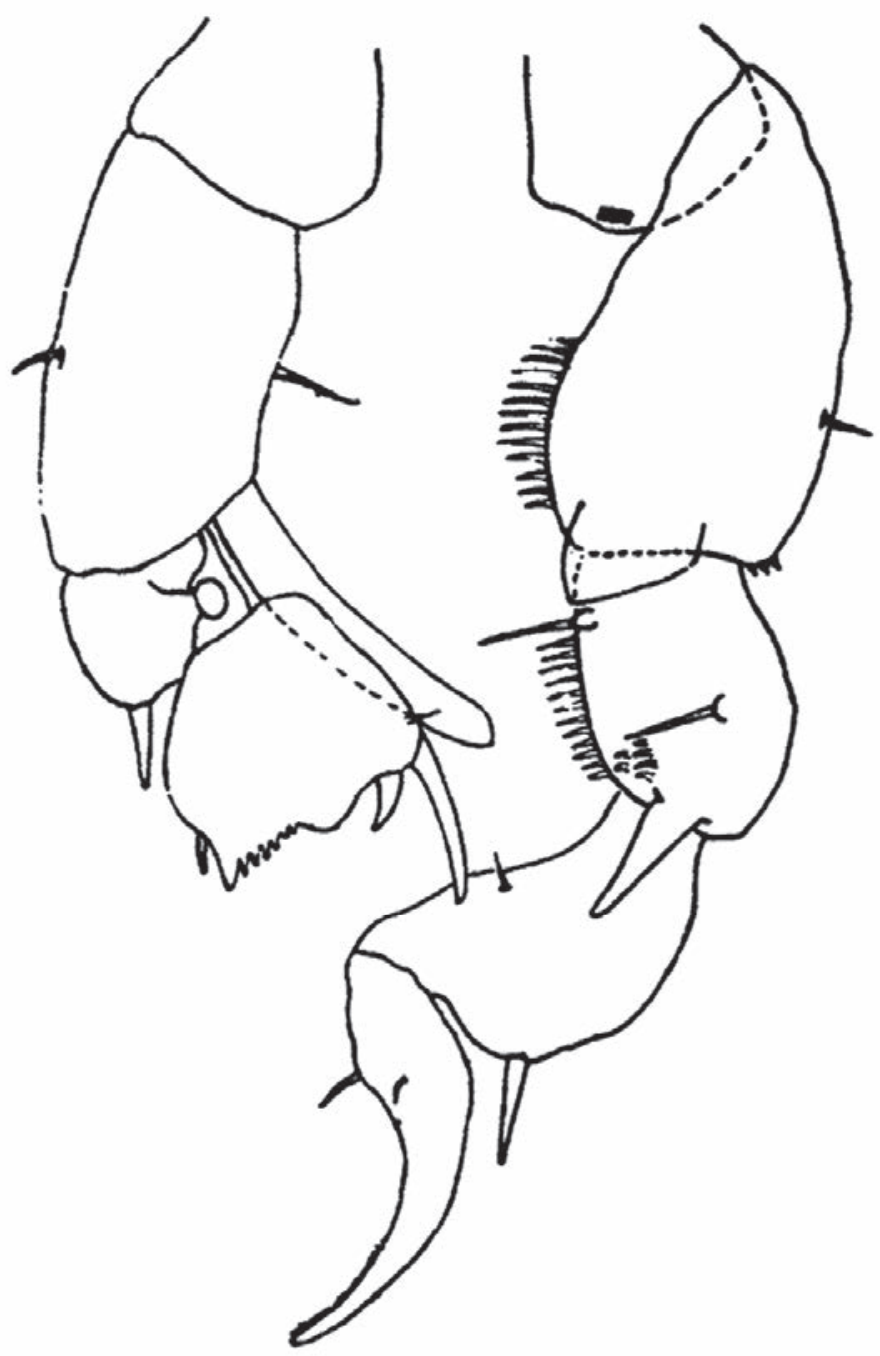

Figure $12 \mathrm{a}-$ Characteristics of $5^{\text {th }}$ leg of male of Pseudodiaptomus richardi. Source: Sars, 1901.

Table 7 - Occurrence of Pseudodiaptomus richardi in the lakes and reservoirs in 1(one) UGRHi of São Paulo State.

\begin{tabular}{ccl}
\hline No UGRHi & Name & Lakes \& Reservoirs \\
\hline 7 & Baixada Santista & Aguapei (Itanhaen) \\
\hline
\end{tabular}




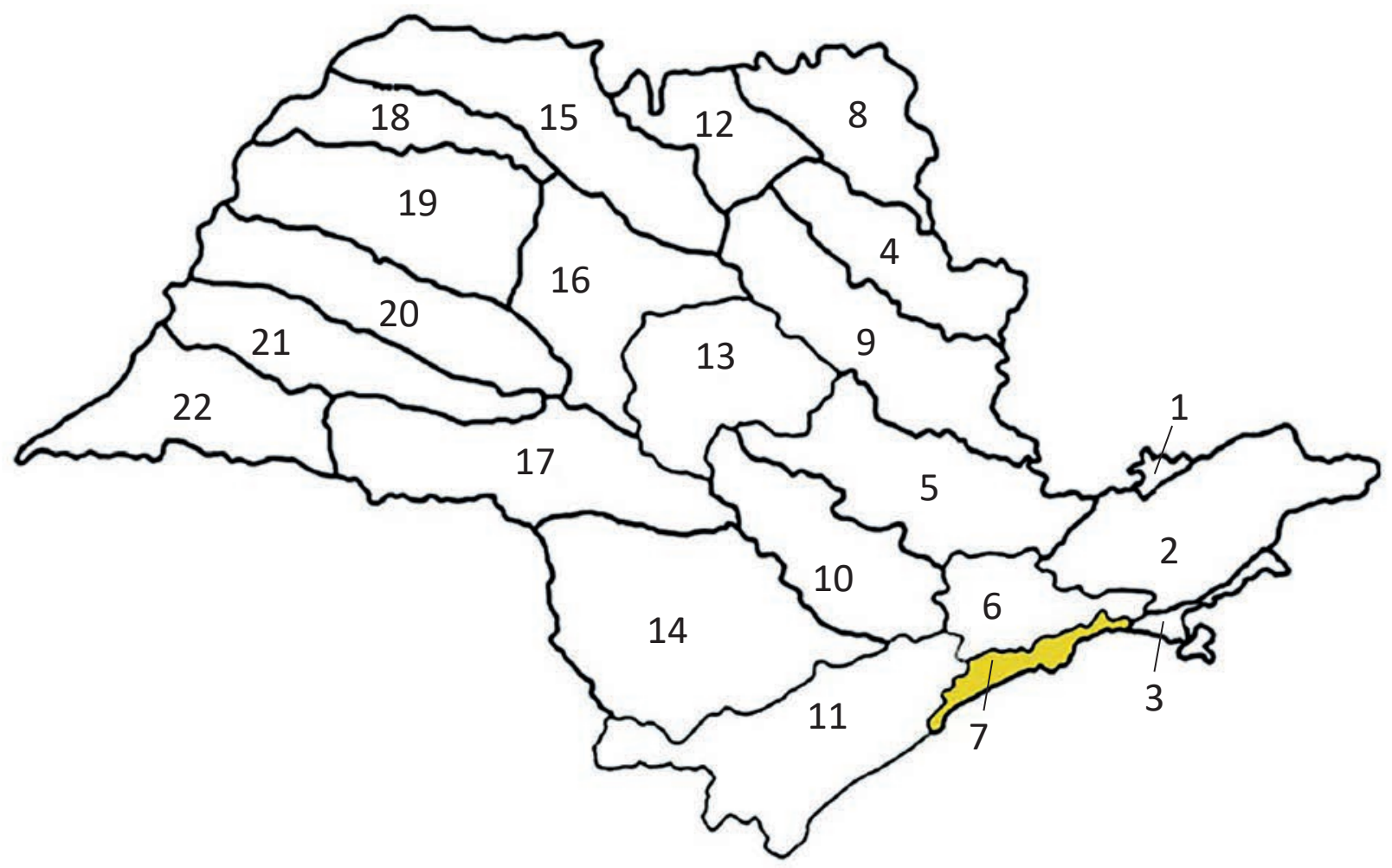

\section{Unidades de Gerenciamento de Recursos Hídricos - UGRHi}

\author{
01 - Mantiqueira \\ 02 - Paraíba do Sul \\ 03 - Litoral Norte \\ 04 - Pardo \\ 05 - Piracicaba/Capivari/Jundiaí \\ 06 - Alto Tietê \\ 07 - Baixada Santista \\ 08 - Sapucaí/Grande \\ 09 - Mogi-Guaçu \\ 10 - Tietê/Sorocaba \\ 11 - Ribeira da Iguape/Litoral Sul
}
12 - Baixo Pardo/Grande
13 - Tietê/Jacaré
14 - Alto Paranapanema
15 - Turvo/Grande
16 - Tietê/Batalha
17 - Médio Paranapanema
18 - São José dos Dourados
19 - Baixo Tietê
20 - Aguapeí
21 - Peixe
22 - Pontal do Paranapanema

Figure 12b - Map of geographical distribution of Pseudodiaptomus richardi in São Paulo State.

\section{Discussion}

The twelve species of Calanoida identified in the freshwater continental ec osystems of São Paulo State (nivers, lakes and reservoirs) can be grouped as those that have large tolerance to environmental factors (c limatological, habitats, chemic al, physic al, hydrogeologic al) as eurioecious species, and those that present a narrow tolerance to these factors as stenoecious species.

Of the identified Calanoida, five species, Notodiaptomus iheringi, Notodiaptomus 
oliveirai, Notodia ptomus spinuliferus, Notodiaptomus henseni and Notodiaptomus venezoelanus deevoyorum can be considered as eurioec io us species. These tolerate an ample spectra of environmental factors with a presence in more than $50 \%$ of the UGRHi of Sã o Paulo State, under the influence of the ma in rivers that limit the frontiers of the major UGRHi: Rio Grande, Rio Paraná, Rio Pa ranapanema, Rio Tietê and Rio Pardo.

The other species such as Argyrod ia pto mus a zevedoi, Odontodia ptomus paulista nus,, Notodia ptomus deitersi, Scolodia ptomus corderoi and Psedodiaptomus richardi are stenoecious species, once their occurrence was registered in a few UGRHi.

As disc ussed by Hutc hinson (1967) most of the species of Ca la noida, specially Diaptomidae have wide tolerance of soft and moderately hard waters. The response of the species of Diaptomidae to environmental factors specially what Hutc hinson (op.cit.) describes as "chemical ec ology of Calanoida" is from field evidences of distribution rather than to experimental work in the laboratory. The endemic ity of Cala noida species is well known from these field samples, therefore. Baily (1969) hás shown a strong correlation between Calanoida distribution in Australian freshwaters ecosystems and the ionic composition of waters specially the $\mathrm{HCO}_{3}^{-}+\mathrm{CO}_{3}^{-}$/clorate. Thus there are ma ny evidences that hydrogeochemic al factors such as the ionic composition of the water, the eutrophic ation and acidific ation processes a re key factors, together with temperature that affect the distribution and survival of Calanoida species. These facts could explain why the copepods Calanoida from Northem hemisphere do not occur in the Southem hemisphere orvice versa. Many a uthors that studied the Dia ptomidae from South hemisphere, since 1891 (POPPE, 1891 described the Diaptomidae from Brasilian material as "Diaptomus" deitersi), described all the Calanoida found as "Diaptomus" until 1958, when Brehm, 1958, c lassified the different "Diaptomus" in several genera.

In response to eutrophic ation changes in the composition of phytoplankton a re expected. Cyanobacteria bloomsare more frequent or permanent components of the phyto plankton community and given the fact that many species of cyanobacteria can produce toxins, it is probably a nother factor that affects the distribution of the Copepoda.

Several reservoirs in São Paulo Sta te changed trophic status in the last 20 years (MATSUMURA-TUNDISI, TUNDISI, 2003; TUNDISI, MATSUMNURA-TUNDISI, 2013) a fact that can explain the changesobserved in the zooplankton composition as regards Calanoida.

As Margalef (1966) pointed out, there is a constant interaction between plants and a nimals and this regulates the speed of phytoplankton and zooplankton succession. Quality of food which is different at each stage of succ ession has a strong influence on zooplankton development and evolution. Food a va ila bility changes, therefore, from smaller partic les at the early stages of succ ession to larger partic les at latter stages of suc cession and this can affect the Copepoda Calanoida distribution. Rietzler et al. (2002) proposed that changes in partic le size and availability was one 
of the factors that caused the change of Argyrodiaptomus furca tus to Notodiaptomus iheringi at Lobo/Broa reservoir.

The production of resting eggs by Copepoda Calanoida is a notherfactor that can expla in the widergeographical distribution of some species and the limited distribution of other species. As stated by Hutchinson (op. cit.) Diaptomidae can produce active and resting eggs The conditions under which the resting eggs hatch is relatively unknown but evidence from Lob/Broa reservoir a shallow ecosystem, with a high level of organic mattercan explain the presence of Argyrodiaptomus furc a tus the unique species of Cala noida present in this reservo ir until 1986. On that time occurred the invasion of Notodiaptomus ihering i in competition with A. furc atus. The conditions of the reservoir a lso were undergoing becoming more eutrophic. Then it is possible to explain that the distribution of Argyrodia ptomus furc a tus oc curs only at the water ecosystems belonging at the UG RHi located in the northeast part of São Paulo State.

Other possible effect on the Copepoda Calanoida composition is the introduction of exoctic species of fishes in the reservoirs of São Paulo State. As shown by MatsumuraTund isi \& Tundisi (2003) major changes in zooplankton Copepoda Calanoida composition occurred ma inly from 1980 to 1990. This was exactly the period during which at least 13 species of fishes from Amazon basin and other basins were introduced. The presence of Notodiaptomus cearensis in the present data and only in the UG RHi, influenced by River Tietê, could be explained by the transportation of this species native from lower la titudes by fishes to São Paulo State, where they found ideal conditions for their a daptation, reproduction and development.

The disappearance or the reduction of the geographic distribution of some speciescan be attributed to changes in the environmental conditions desc ribed above. Eutrophic ation, changes in the ionic composition or predation can be factors that limit the distribution or contribute for the changes in species composition. As Margalef (op. cit.) pointed out new empty spaces are continually produced in places where ec osystems a re a ltered completely. Direct reactions of orga nisms to environmental change is most useful when the environment is altered in an unpredic table way. Reservoirs, lakes and rivers respond to environmental changes from the watershed inputs or the human a ctivities in na unpredic table way depending on soil uses, the water uses, the load of nutrients and suspended material. Therefore a change in composition of Copepoda Calanoida should be expected under these dynamic and not so orga nized environmental conditions. These events may explain the retraction of the occurrence of Scolodiaptomus corderoi and Notodiaptomus conifer in the reservoirs os Sã o Paulo State. Both species were present in 1979 in several resenoirs a related by Matsumura-Tundisi, Tund isi, 2003. At present Sc olodia ptomus corderoi occurred in the reservoirs belonging at only three UGRHi, and Notodiaptomus conifer disa ppea red completely.

As stated by Matsumura-Tund isi, Tundisi (2003), during the decades of 1980 
and 1990, eutrophic ation, acidific ation, the load of nutrients, suspended material and ionic composition changed drastic ally in several resenoirs of Sã o Paulo Sta te.For example in Barra Bonita reservoir amonium content $\left(\mu \mathrm{gL}^{-1}\right)$ had an inc rea se of $200 \%$; conduc tivity changed from $100 \mu \mathrm{Sc} \mathrm{m}^{-1}$ in 1979 to $370 \mu \mathrm{Scm}^{-1}$ in 2002 and the presence of sulphate íon ( $\mathrm{SO}_{4}^{--}$) was detected during 2002 sampling.

Several books and papers reported extensive changes in the limnological conditions of the reservoirs in São Paulo Sta te in the last 20 years (TUNDISI, MATSUMURA-TUNDISI, 2013). This would favor the expansion in the distribution of some species and the reduction in the geographical distribution of other species.

As Margalef (1966) pointed out nature is a channel of information. The genetic channel is replic able ind ividual struc tures. Then the genetic channel of information should probably be the response of the Copepoda Calanoida community to changes in the environment. The appearance of new species as Notodia ptomus oliveirai, would also be a consequence of this response. Due to the dynamic and rapid changes in the environmental conditions and the effect of man a c tivities the genetic channel has been enlarged more rapidly than the ecological channel. The cultural channel of information was very much enlarged, too. This expla in the changes and the appearance of new species in the zooplankton community of Copepoda Calanoida.

Reservoirs are complex systems. They are dynamic and variable ecosystems responding rapidly to the impacts of human activities ("the cultural channel", sensu Margalef, 1966). Effects of intra spec ific competition, predation and changing environmental conditions would be responsible for the composition and succession of zooplankton community (PIANKA, 1999). The response of the Copepoda Calanoida populations dwelling in the reservoirs of Sã o Paulo State can be a good example of the impact of man on the ecosystem struc ture and function.

\section{Acknowledgements}

This work is part of the BIOTA/FAPESP - The Biodiversity Virtual Institute Program (www. biotasp.org.br). The authors express their gratitude to FAPESP for financial sup port (Processes: 1290-7/78; 98/5092-2). 


\section{References}

BAILY, I.A.E., 1969. The occurrence of calanoid copepods in athalassic saline waters in relation to salinity and anionic proportions. Verh. Int. Ver. Limnol. vol. 17, pp. 449-455.

BREHM, V., 1958, Bemerkungen zu einigen Kopepoden Südamerikas. Sber. Öst. Akad. Wiss., Abt. I., vol. 167, pp. 139-171.

DUSSART, B.H., MATSUMURA-TUNDISI, 1986. Nouvelles espèces de calanoides du Brèsil. Rev. Brasil. Biol. 46:249-255.

ESPINDOLA, E.L.G., 1994. Dynamics of congeneric species of Notodiaptomus (Copepoda Calanoida from Barra Bonita Reservoir, São Paulo, Ph D thesis, University of São Paulo. 363pp

HUTCHINSON, G.E., 1967. A treatise on Limnology. vol II, Introduction to lake biology and the limnoplankton. John Wiley \& Sons, Inc., New York-London-Sidney, $1115 \mathrm{pp}$.

MARGALEF, R., 1968. Perspectives in Eological Theory. The University of Chicago Press, Ltd, W.C. 1. 111 pp

MATSUMURA-TUNDISI, T., 1986. Latitudinal distribution of Calanoida copepods in freshwater aquatic ecosystem of Brazil. Rev. Brasil. Biol., vol. 46, no. 3, pp. 527-553.

MATSUMURA-TUNDISI, T., 2008. Rectification of description of Notodiaptomus spinuliferus, Dussart and Matsumura-Tundisi, 1986. Raz. J. Biol. vol. 68 no. 3, pp. 683-684.
MATSUMURA-TUNDISI, T., TUNDISI, J.G., 2003. Calanoida (Copepoda) species composition changes in the reservoirs of São Paulo State (Brazil) in the last twenty years. Hydrobiologia, vol. 504, Kluwer Academic Publishers. Netherlands.

MATSUMURA-TUNDISI, T., ESPINDOLA, E.L.G., TUNDISI, J.G., SOUZA-SOARES, F. and DEGANI, R.M., 2010. A new species of Notodiaptomus Kiefer (Crustacea, Copepoda, Calanoida, Diaptomidae) from Brazil. Braz. J. Biol. vol. 70, n. 3, pp. 867-870 (Suppl).

PIANKA, E.R., 2000. Evolutionary Ecology. 6th ed., Addison Wesley Educational Publishers, Inc. p. 431.

POPPE, V.M., 1891. Ein Neuer Diaptomus aus Brazilien. Zool. Anz. no. 355, pp. 248-250.

MATSUMURA-TUNDISI, T. (coord). 2003. Biodiversidade do zooplancton de águas continentais. Progress Report, vols. 1, 2, 3, 4. (Processo: 1998/05091-2).

RIETZLER, A.C., MATSUMURA-TUNDISI, T. and TUNDISI, J.G., 2002. Life cycle, feedingand adaptive strategy implications on the co-occurrence of Argyrodiaptomus furcatus and Inotodiaptomus iheringi in Lobo/Broa reservoir (SP, Brazil). Braz. J. Biol., vol. 62, pp. 93-105.

TUNDISI, J.G. (coord), 1980. Tipologia de reservatórios do Estado de São Paulo. Progress Report, vols. 1, 2, 3. (FAPESP- Processo: 1290-7/78).

TUNDISI, J.G. and MATSUMURA-TUNDISI, T., 2013. The ecology of UHE Carlos Botelho (Lobo-Broa Reservoir) and its watershed, São Paulo, Brazil. Freshwater Reviews, no. 6, pp. 75-91. Freshwater Biological Association Publ. 


\section{Integrated Management Plan for the Itaquri Lobo Watershed and UHE Carlos Botelho (Lobo/Broa) Reservoir}

Tund isi, J .G . ${ }^{1}$, Matsumura-Tund isi, T. ${ }^{2}$, Tund isi, J .E. ${ }^{2}$

${ }^{1}$ Feevale University, Novo Ha mburgo, RS.

${ }^{2}$ Instituto Internacional de Ecologia, São Carlos, SP.

Corresponding author: tundisi@iie.com.br

\section{Abstract}

This paper refers to the management plan for the watershed and reservoir of the UHE Carlos Botelho, also known as Lobo/Broa. The management is based on the ILBM Platform Process, that is Integrated Lake Basin Management. It includes three main basin regulations and management: basin water qua lity regula tions; basin infra struc ture development plans; basin water quality plans.

The management plan is based on the scientific and technical developments at the watershed and reservoir since 1971.

Keywords: watershed, reservoir, limnology, management, water resources.

\section{Introduction}

Lobo/Broa reservoir is situated in the Ita queri/Lobo watershed. The watershed and the reservoir have the following characteristic s: La titude: $22^{\circ} 15^{\prime} \mathrm{S}$, Long itude: $47^{\circ} 49^{\prime} \mathrm{W}$; Area of watershed: $230 \mathrm{~km}^{2}$;
Area of reservoir: $7 \mathrm{~km}^{2}$; Mean depth of reservoir: 3.0 meters; Volume of reservoir: $22.000 .000 \mathrm{~m}^{3}$.

The watershed islocated in a region of Savanna vegetation ("cerrado") cover and areas of reforestation with Pinus sp and Eucalyptus sp. 
Clima tologic a I fluc tuations shows higher precipitation during summer, very little precipitation during winter and an a verage of $1.500 \mathrm{~mm}$ of ra infall during the yearconcentrated in the summer months (November to March/April) (TUNDISI, MATSUMURA-TUNDISI, RODRIGUES, 2003).

Wind speed is a round $10 \mathrm{~m} / \mathrm{s}$ during the winter. Due to the shallowness of the reservoir, a permanent mixing occurs in the open water. Retention time is a round 20 days. The reservoir is used for hydropower generation ( $2 \mathrm{MW} / \mathrm{h}$ ); recreation; sport fisheries; to urism; a qua tic sports.

The reservoir has an important economical input for the region rec eiving a round 10.000 tourists in the weekends specially during the summer. Periotto, Tundisi (2013) identified 20 servic es of watershed and the reservoir that a re useful to the human well being and to the biologic al communities of terrestrial and aquatic organisms.

Therefore a management plan for the watershed and reservo ir is essential in order to secure permanently a good soil use, pollution control, adequate water qua lity that will enhance touristic a c tivities with economic impact. The management plan was based on the IBLM Platform Process (NAKAMURA, RAST, 2011).

\section{The management plan}

Figure 1 shows the integrated management plan for the reservoir and the watershed. The main purpose of this paper is to inform and guide the process of watershed and resenoir govemance and the implementation of programs, polic ies and actions in a $n$ integrated and systemic view with a mple participation of the basin communities, sta keholders, with high accountability and responsibility. This management plan is, to a large extent based on the research, planning and monitoring a c tivity ca ried on in the watershed and reservoir since 1971, and in disc ussion with a II munic ipa lities, involved, sta keholders, research workers and The Public Ministry of S. Paulo State dedicated to this a rea (GAEMA) (TUNDISI, MATSUMURA-TUNDISI, RODRIG UES 2003; TUNDISI, MATSUMURATUNDISI, 2013, TUNDISI, 2017).

\section{Discussion and Conclusion}

As reported by Nakamura and Rast (2011) ILBM Platform a ctivities develops a series of a ctivities and steps in the following flows:

- Describe the state of lake/reservoir basin management. Develop a lake/reservoir brief.

- Prepare a database and knowledge bases of data and information from monitoring, reconnaissance, survey, inventory.

- Analyze the existing information to ensure a systemic approach and a integrated overview of ecosystems (watershed and reservoir).

- Integrate ways and means for implement future actions.

- Coordinate stakeholder consultations.

- Evaluate improvements in governance issues. 


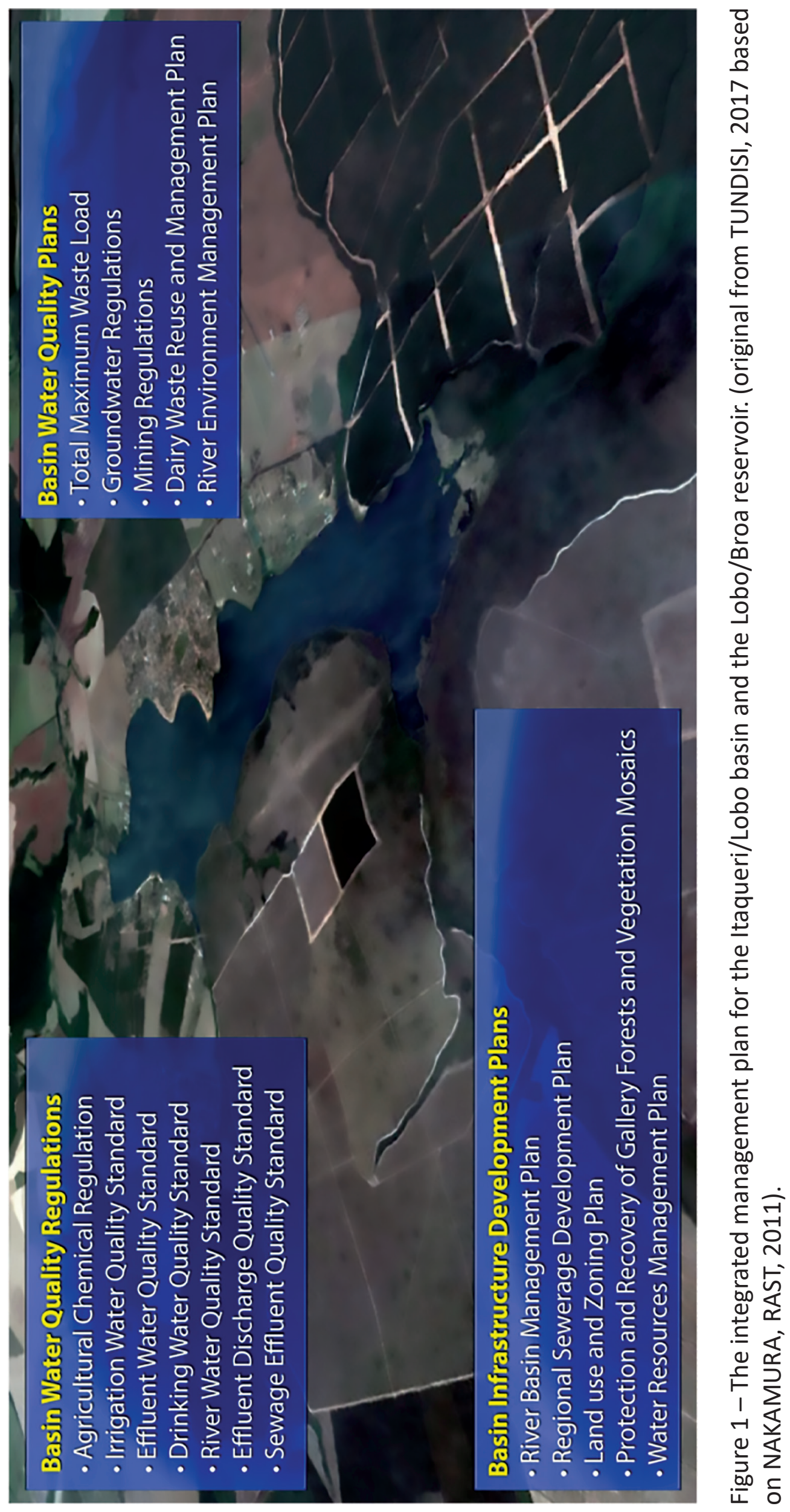


This integrated management plan is complex due to several plans and regulations. Watershed and reservoirs a re complex ecosystems with many interactions, of c lima tologic al, hydrologic al, hidrogeoc hemic al, biologic al and geomorphological process in a dynamic, spatial and temporal succession and fluc tuations. All these complexities were studied at Lobo/Broa reservoir and Itaqueri/ Lobo watershed. Therefore the next step is to promote a sound management

\section{References}

NAKAMURA, M. and RAST, W., 2011. Development of ILBM Platform Process: evolving guidelines through participatory improvement. RCSE. Shiga University and ICEC. 76 pp.

PERIOTTO, N.A. and TUNDISI, J.G., 2013. Ecosystem services of UHE Carlos Botelho (Lobo/Broa): a new approach for management and planning of dams multiple uses. Braz. Journ. Biol., vol. 73, pp. 471-482.

TUNDISI, J.G., MATSUMURA-TUNDISI T. and RODRIGUES S.L., 2003. Gerenciamento e recuperação das bacias hidrográficas dos rios Itaqueri e Lobo e da UHE Carlos Botelho (Lobo/Broa). IIE/IIEGA, ELEKTRO. pp. 54. plan structured in the basic knowledge developed after many years of research (TUNDISI, MATSUMURA-TUNDISI, 2013; TUNDISI, 2017).

\section{Acknowledgements}

The a uthors a cknowledge the fina ncial support of FAPESP-PELD project (2012/51502-3) for the research at the Lobo/Broa reservoir and Itaqueri/Lobo watershed. The support of CNPq for PELD is a lso a c knowledge (Process: 441564/2016).

TUNDISI, J.G. and MATSUMURA-TUNDISI, T., 2013. The ecology of UHE Carlos Botelho (Lobo/Broa) reservoir and its watershed. São Paulo, Brazil. Freshwater Reviews, vol.6, pp. 75-91.

TUNDISI, J.G., 2017. Pesquisas ecológicas de longa duração na bacia dos rios Itaqueri e Lobo e na represa da UHE Carlos Botelho (Lobo/Broa) Itirapina, $S P$, Brasil. Relatório Final - FAPESP, Projeto PELD Pesquisas Ecológicas de longa duração. pp. 82. 


\title{
Enhancing Methane Yields by Anaerobic Co-digestion of Sludge with Food Residues*
}

\author{
Aburawaa, A. A. ${ }^{1}$, Alrousan, D. ${ }^{2}$, Hayek, B. ${ }^{3}$
}

${ }^{1}$ G IZ Water Portfolio - J ordan, Field Project Officer, Decentra lized Integrated Sludge Management (DISM) project, Dept. of Water Management and Environment, Faculty of Natural Reso urc es and Environment, Ha shemite University.

${ }^{2}$ Dept. of Water Management \& Environment, Faculty of Natural Resources \& Environment, Ha shemite University.

${ }^{3}$ GIZ Water Portfolio - J ordan, Team Leader, Decentralized Integrated Sludge Management (DISM) project.

Corresponding author: aaburawwa@yahoo.com, ayman.aburowaa@giz.de,dheaya@ hu.edu.jo; dheaya@gmail.com, bassam.hayek@giz.de, ba sam.hayek@gma il.com

*This publication has been produced as a result of the Deutsche Gesellschaft für Internationale Zusammenarbeit (GIZ) G mbH implemented project "Decentralized Integrated Sludge Management"- DISM activities on behalf of the German Federal Ministry for Economic Cooperation and Development (BMZ).All rights for the content of this paper are reserved for $G \mathrm{IZ}$, the views presented are entirely the responsibility of the authors.

\section{Abstract}

Disposal of biodegradable waste (food residues and sewage sludge) has become a stringent waste management and environmental issue. As a result, anaerobic digestion has become one of the best altemative technologies to treat the food wastes and sewage sludge which can be an important source of bioenergy. This study focuses on the evaluation of biogas and methane yields from the co-digestion of different sewage sludge and food wastes mixture ratios. The biogas potential tests using both types of substrates were performed in la b scale and under mesophilic conditions $\left(35^{\circ} \mathrm{C}\right)$. It was observed that the optimal mixing ratio of food waste to sewage sludge was $1: 2$, corresponding to biogas production of $0.184 \mathrm{Nm}^{3} / \mathrm{kg}$ VS. The study examines 
the possibility of increasing biogas production up to $75 \%$ using food waste substrate addition to sewage sludge inanaerobic co-digestion.

Keywords: a naerobic, co-digestion, food residues, sewage sludge, methane, meso philic conditions.

\section{Introduction}

About 50' 000 tons of dried solid sludge are generated a nnually in J ordan as a by product of wastewater treatment in the 31 wastewater treatment plants (WWTP) distributed all over J ordan and treating more than $152 \mathrm{MCM}$ peryear (MWI, 2015). Around $60 \%$ of the total municipal wastewater produced in J ordan is treated in As-Samra WWTP in Zarqa governorate, the plant serves the biggest two cities, Amman and Zarqa, where $71 \%$ of the population a re living. To accommodate for the increasing demand, As-Samra WWTP is currently undergoing expansion to reach a daily capacity of $367,000 \mathrm{~m}^{3}$. As-Samra WWTP utilizes a na erobic digesters to stabilize sludge, which is then dewatered using belt filter press system. While As-Samra's sludge is utilized as energy sources, only one of the other 30 wastewater trea tment fa cilities has proper utilization of sludge for energy production, which is in AI Shalalah WWTP in the north of J ordan. Thus the qua ntities of generated sludge in other treatment plants still crea te a serious environmental problem.

Nowadays, sludge management is a n integral part of a ny modern municipal wastewa ter treatment plant in order to dispose sludge in a proper environmental way and also economic ally not to lose sludge valuable nutrients and to make efficient use of material and energy. Simila rly, J orda n suffers from a solid waste crisis, which is looming in J ordan with more than 2 million tons of municipal waste and 18,000 tons of ind ustrial wastes are being generated a nnually. Alarmingly, less than $5 \%$ of total solid waste is c urrently recycled in J ordan.

Because of the growing demand on energy and limitation of resource in J ordan, wastewater sludge and solid wastes can be considered as a ltema tive sourc es for energy production. Nowadays the possibilities for biogas production as a $n$ a Iternative energy source a re becoming more important (MOUSDALE, 2008), and from a practical viewpoint determining the capabilities of different organic materials to produce biogas a re vital. Ana erobic digestion (AD) and Co-digestion are promising environmental susta inable biotechnologies that can treat the organic fraction of the municipal solid waste and wastewater sludge to produce biogas as a source of energy. Using such biotechnologies would necessa rily help in solving the problem of the huge accumulated sewage sludge and food wastes and reduce the greenhouse gases emissions from them. Digestion process will result in enhancing physical and chemic al characteristic s of sludge and make it more suitable for land applic ations.

The process of a naerobic digestion consists of three steps: Solubilization, 
Acidogenesis, and Methanogenesis (KIM, 2003). In the first hydrolysis step, the complex organic polymers (proteins, carbohydrates, and fats) a re degraded into simple sugars, a mino acidsand fatty acids by the heterogeneous mic roorga nism. As the second step, acidogenic bacteria produce fermentation intermediates, ma inly volatile fatty acids (VFAs), and lastly, in the methane step, methane and carbon dioxide with a small amount of hydrogen $\left(\mathrm{H}_{2}\right)$ and traces of hydrogen sulphide $\left(\mathrm{H}_{2} \mathrm{~S}\right)$ and ammonia $\left(\mathrm{NH}_{3}\right)$ are produced from these intermediates by methanogenic bacterial meta bolism (ABATZO GLOU, 2009). In each step, the gas production and decomposition rates of organic waste are influenced by environmental factors such as temperature, $\mathrm{pH}$ and hydraulic retention time (HRT) and substrate concentration (CRISTANCHO, 2006; G ÜNGÖ R-DEMIRCI, 2004; MATA-ALVAREZ, 2002).

Anaerobic digestion is conducted using simple reactor technologies such as Single Batch reactor, continuous stirred tank reactor (CSTR) and Plug flow reactor (PFR), (RITTMANN, 2012), The degradation process is complex and depends on a balanced action of several microbial groups (GUJ ER, 1983) in the absence of oxygen and renewable energy biogas is generated (CHEN, 2008).

Biogas from the anaerobic degradation of wastewater can be used in microturb ines or internal combustion engines for generating elec tric ity (CRAWFORD, 2010). The US EPA estima tes that over $80 \%$ of munic ipa lities that utilize a na erobic digestion fla re excess biogas (EPA, 2007). Typ ic al digester gas energy recovery systems can recover $20-40 \%$ of the energy requirement for wastewater treatment plants that use the activated sludge process (CRAWFORD, 2010).

A substance or compound is biodegradable if it can be source of energy for the metabolism and for the growth of the biomass which performs its degradation; on the contrary, a substance is indicated as poorly or nonbiodegradable, if structural (molecular) or extemal causes (concentra tion levels, a va ila bility of nutrients, etc.) hinder their degradation and thus remains partially or totally undegraded in the environment. It may happen that some intermediates are more recalcitrant or even toxic. The degradation process is complex and depends on a balanced action of several microbial groups (GUJ ER, 1983) in the absence of oxygen and renewable energy biogas is generated (CHEN, 2008).

Some factors may influence the activity of mic roorganisms, thus the biodegradation process. From a bioc hemical point of view, temperature and $\mathrm{pH}$ influence the reaction rate of an enzymatic process, in the sense that each enzyme is characterized by an optimal range of temperature and pH. Generally, when the temperature increases, the reactions are accelerated and the growth rate is higher; but if the temperature becomestoo high, a process of irreversible denaturation of the cellular components may occur whereas if the temperature becomes too low, both the bacterial growth and substrate utilization eventually cease.

On behalf of the German Federal Ministry for Economic Cooperation and Development (BMZ), GIZ is supporting the Water Authority of J ordan in its efforts to find suitable solutions for the treatment and reuse of sewage sludge. The project 
a ims to reduce the carbon footprint of the sludge handling process. To this end, it considers the use of sludge prima rily as a source of energy, but also as a soil conditioner and a fertilizer. The project also seeks to demonstrate an integrated approach to the treatment and reuse of sludge in combination with other biomass sources (co-digestion). After the energy potential of the sludge has been tapped, any residual sludge undergoes further processing, together with other sources of biomass, to produce a treated organic mix that can be used to improve soil quality. The integrated approach ensures the involvement of all significant stakeholders, from the relevant ministries and munic ipa lities, to the water utilities and farmers. The project also includes close sc ientific cooperation with Mu'ta University in Karak by building and operating a naerobic co-digestion experiments using a (100 L) STR system and using the same biomass, the University is located close $(2.5 \mathrm{~km})$ to the Mu'ta-Mazar demonstration plant in the Govemorate of Karak.

\section{Objective}

The objective of the current study was to find the maximum mixing ratio of food waste and sludge, and methane production using Laboratory Equipment Modular compact basis plant BTP-2 which is the standard system for substra te testing and gas yield tests.

\section{Material \& Methods}

The biogas yield experiment in Mu'ta Almazar WWTP was performed to simulate the real digester. For this purpose, the (Modular compact basis plant BTP-2) device is ideal as shown in Figure 2. The device has one testing unit with reactor volume capacity up to $17 \mathrm{~L}$ of degradable material (liquid or pulps). The units can be thermostatic ally managed from 0 to $60^{\circ} \mathrm{C}$, with temperatures of $35-55^{\circ} \mathrm{C}$ a re ideal for the ana erobic tests. The device is equipped with a mixer, stirring the solution at programmed mixing intervals. With continuous monitoring of $\mathrm{pH}$-values, temperature and biogas production. Data collection using data loggertechnology.

The producing of biogas is a nalyzed with OPIMA 7 biogas a na lyzer as shown in Figure 3 simulta neous mea surements of up to 7 gascomponents. The biogas measurements include $\mathrm{O}_{2}, \mathrm{H}_{2} \mathrm{~S}, \mathrm{CH}_{4}$ and $\mathrm{CO}_{2}$ (infrared for $\mathrm{CO}_{2} / \mathrm{CH}_{4}$ ).

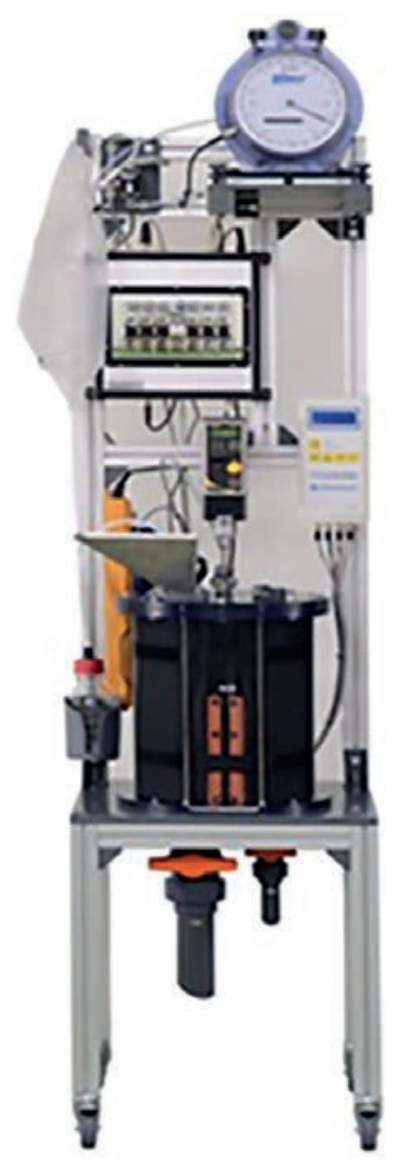

Figure 1 - Biogas Test Plant BTP2. 


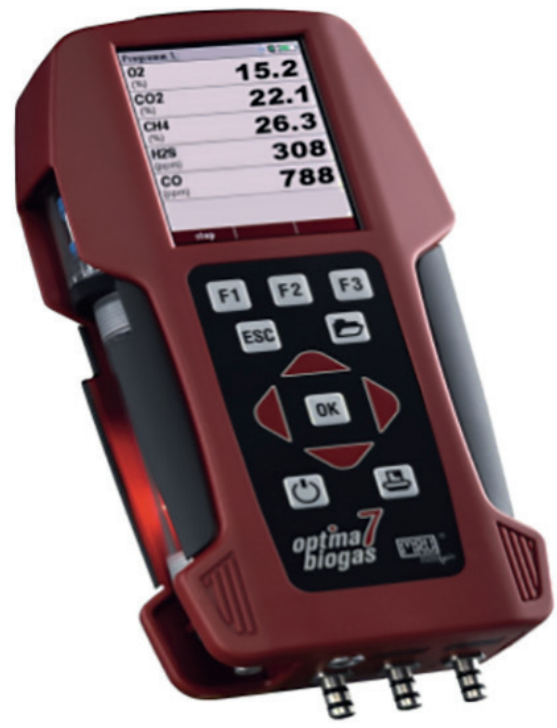

Figure 2 - OPTIMA Biogas Analyzer.

\section{Seeding S7udge ( Inocula)}

Seeding sludge (Inocula) was taken from Mu'ta university biogas reactor. Once collected, the seeding sludge was added to biogas BTP-2. Analyses of its volatile and total solids content (VS, TS) were performed at the lab of the WWTP.

\section{Substrate}

Sludge and a mixture of food residues and sludge were used as substrate in this study. Food residues were taken from Mu'ta University military wing restaurant, after grinding by a electric blender, the material was stored in a refrigera tor at $4^{\circ} \mathrm{C}$. The sludge wastaken from Mu'ta Almazar WWTP, the physic oc hemic al parameters $(\mathrm{pH}, \mathrm{TS}, \mathrm{VS}, \mathrm{T}-\mathrm{N})$ were determined according to standard methods (Standard methods for the examination 2010) in the Royal Scientific Society (RSS) and Eurofins Umwelt
Ost G mbH Hauptniederlassung J ena, berlin - Germany. The physic ochemical cha racteristic s of substra te a re presented in Table 1.

Table 1 - Physicochemical Characteristics of substrate used in this study.

\begin{tabular}{lcc}
\hline \multicolumn{1}{c}{ Parameters } & Sludge & Foodwaste \\
\hline $\mathrm{pH}$ & 6.75 & 4.6 \\
\hline Total Solid \% & 0.61 & 32.1 \\
\hline Volatile Solid \% & 59.2 & 29.8 \\
\hline Electrical & & \\
Conductivity $\mu \mathrm{s} / \mathrm{cm}$ & 2400 & \\
\hline Total Nitrogen \% & 34.1 & 2.8 \\
\hline $\mathrm{NH}_{4}-\mathrm{N} \%$ & 22.4 & 0.003 \\
\hline $\mathrm{NO}_{3}-\mathrm{N} \mathrm{mg/Kg}$ & 281 & $<10$ \\
\hline
\end{tabular}

Productivity, yield, and degree of degradation

Productivity $\left(\mathrm{P}_{(\mathrm{CH} 4)}\right)$, yield $\left(\mathrm{A}_{(\mathrm{CH} 4)}\right)$ and degree of degradation $\left(\eta_{V S}\right)$ are appropriate parameters for describing the performance of a biogas experiment. If gas production is given in relation to digester volume, this is referred to as the productivity. This is defined as the quotient of daily gas production and reactor volume and is consequently an indic ation of the efficiency. Productivity can be related to both biogas production $\left(P_{\text {(biogas) }}\right.$ ) and methane production $\mathrm{P}_{(\mathrm{CH} 4)}$ and is given in $\mathrm{Nm}^{3} /\left(\mathrm{m}^{3} \cdot \mathrm{d}\right)$.

$$
P_{\left(\mathrm{CH}_{4}\right)}=\frac{V_{\left(\mathrm{CH}_{4}\right)}}{V_{R}}\left[\mathrm{Nm}^{3} \mathrm{~m}^{-3} \mathrm{~d}^{-1}\right]
$$


Where:

Methane productivity

$\mathrm{V}_{\left(\mathrm{CH}_{4}\right)}$ :methane production $\left[\mathrm{Nm}^{3} / \mathrm{d}\right]$;

$\mathrm{V}_{\mathrm{R}}$ : reactor volume $\left[\mathrm{m}^{3}\right]$.

Gas production expressed in relation to the input materials is the yield (Lebuhn 2014). The yield can likewise be related to biogas production ( $A_{(\text {biogas) }}$ ) or methane production $\left(\mathrm{A}_{(\mathrm{CH} 4)}\right)$. This is defined as the quotient of the volume of gas produced and the amount of organic matteradded and is given in $\mathrm{Nm}^{3} / \mathrm{t} \mathrm{VS}$.

$$
A_{\mathrm{CH}_{4}}=\frac{V_{\mathrm{CH}_{4}}}{m_{V S}}\left[N m^{3} t^{-1} V S\right]
$$

Where:

Methane yield

$\mathrm{V}_{\mathrm{CH}_{4}}$ : methane production $\left[\mathrm{Nm}^{3} / \mathrm{d}\right]$;

$\mathrm{m}_{\mathrm{vs}}$ : added volatile solids $[\mathrm{t} / \mathrm{d}]$ ).

The yields denote the efficiency of biogas production or methane production from the loaded substrates. They a re of little informa tive value as ind ividual pa ra meters, however, because they do not include the effective loading of the digester. For this reason, the yields should a lways be looked at in connection with the orga nic loading rate. The degree of degradation $\left(\eta_{v s}\right)$ provides information about the efficiency with which the substrates a re converted. The degree of degradation can be determined on the basis of volatile solids (VS) or chemic al oxygen demand (COD). Given the a nalytic al methods most commonly used in practice, it is advisable to determine the degree of degradation of the volatile solids (LEBUHN, 2014).

$\eta_{V S}=\frac{V S_{s u b} \times m_{F M}-\left(V S_{v s c} \times m_{v s c}\right)}{V S_{s u b} \times m_{F M}} \times 100 \% \mathrm{Eq}$. (3)

Where:

Degree of degradation ( $\left.\eta_{\mathrm{Vs}}\right)$ of biomass,

$\mathrm{VS}_{\text {Sub }}$ : volatile solids of added fresh mass $[\mathrm{kg} / \mathrm{t} \mathrm{fm}]$;

$\mathrm{m}_{\mathrm{FM}}$ : mass of added fresh mass [t];

$\mathrm{VS}_{\mathrm{vsc}}$ : volatile solid content of digester discharge $[\mathrm{kg} / \mathrm{t} \mathrm{FM}$;

$\mathrm{m}_{\mathrm{vsc}}:$ mass of digestate [t])

\section{Experimental Design}

The experiment was conducted using $17 \mathrm{~L}$ reactor of modular compact basis plant BTP-2 as shown in Figure 1 . The va rious mixtures of food residual and sewage sludge were added to each batch experiment. Their initial concentrations were all set, as shown in table 3. Each experiment contained organic waste co-digested with different ra tio of sludge, food residual and Inocula. The experiment was started with Inocula $100 \%$, other treatments were made by mixing food residual/sludge by a ratio of (30\%, 50\%) food residue addition as volatile solid (VS), and the final experiment have been $100 \%$ sludge. Everythirty minutes temperature, gas flow rate, total gas volume and $\mathrm{pH}$ value and stimingat $100 \mathrm{rpm}$ a re carried out by the device, while maintaining temperature at $35 \pm 5^{\circ} \mathrm{C}$. 
Table 2 - Batch experiment operating conditions.

\begin{tabular}{cccccc}
\hline \multirow{2}{*}{ Temperature } & Batch & \multicolumn{4}{c}{ Preparation of Substrate } \\
\cline { 2 - 6 } & $\begin{array}{c}\text { Experiment } \\
\text { No. }\end{array}$ & $\begin{array}{c}\text { Sewage } \\
\text { Sludge } \\
\text { (\% of VS) }\end{array}$ & $\begin{array}{c}\text { Sewage } \\
\text { Sludge } \\
\text { (g VS add) }\end{array}$ & $\begin{array}{c}\text { Food waste } \\
\text { (\% of VS) }\end{array}$ & $\begin{array}{c}\text { Food waste } \\
\text { (g VS add) }\end{array}$ \\
\hline \multirow{2}{*}{$\begin{array}{c}\text { Mesophilic } \\
\left(35^{\circ} \mathrm{C}\right)\end{array}$} & 1 & 100 & 29.4 & 0 & 0 \\
\cline { 2 - 6 } & 2 & 75 & 29.4 & 25 & 10.6 \\
\hline
\end{tabular}

\section{Result and} Discussion

Effect of food waste addition on co-digestion performance based on mixing ratio food waste with sludge used in $\mathrm{BMP}$, three batch experiments were operated at $35 \circ \mathrm{C}$ with different mixtures of foodwaste and sewage sludge using mesophilic seed sludge. As shown in Figure 3, accelerated hydrolysis was observed by the addition of the properamount of food waste within the same temperature conditions. Mesophilic digestion showed a higher conversion rate in hydrolysis as well as acidogenesis. In mesophilic conditions, the major portion of biogas was sharply increased within the first six days by fast acidogenesis and metha nogenesis. In ana erobic digestion of organic materials including large molecules or steric ally incompatible molecules or crysta lline molecules, which cannot be easily transported into the bacterial cells, a further step of hydrolysis by exoenzymes should be considered (Borghi 1999).

Figure 4 shows that as the mixing ratios of food waste increased up to $35 \%$, c umulative biogas production a lso inc rea sed. Simila r observation was reported by (HEO, 2004) for the digestion of sepa rately collected (SC) food residuesand sewage sludge. Therefore, it indic ated that the application of co-substrate signific a ntly improved feed characteristics, resulting in higher biogas and methane potential.

Higher ultimate metha ne yield of food waste can be found in Table 3, which shows reported data from various OFMSW. Also, it was confirmed that co-substrate, food waste, gave higher methane yields thanpreviously reported BMP values (Table 3 ). 

- Mixture 30\% food _ sludge — Mixture 50\% food with sludge with sludge

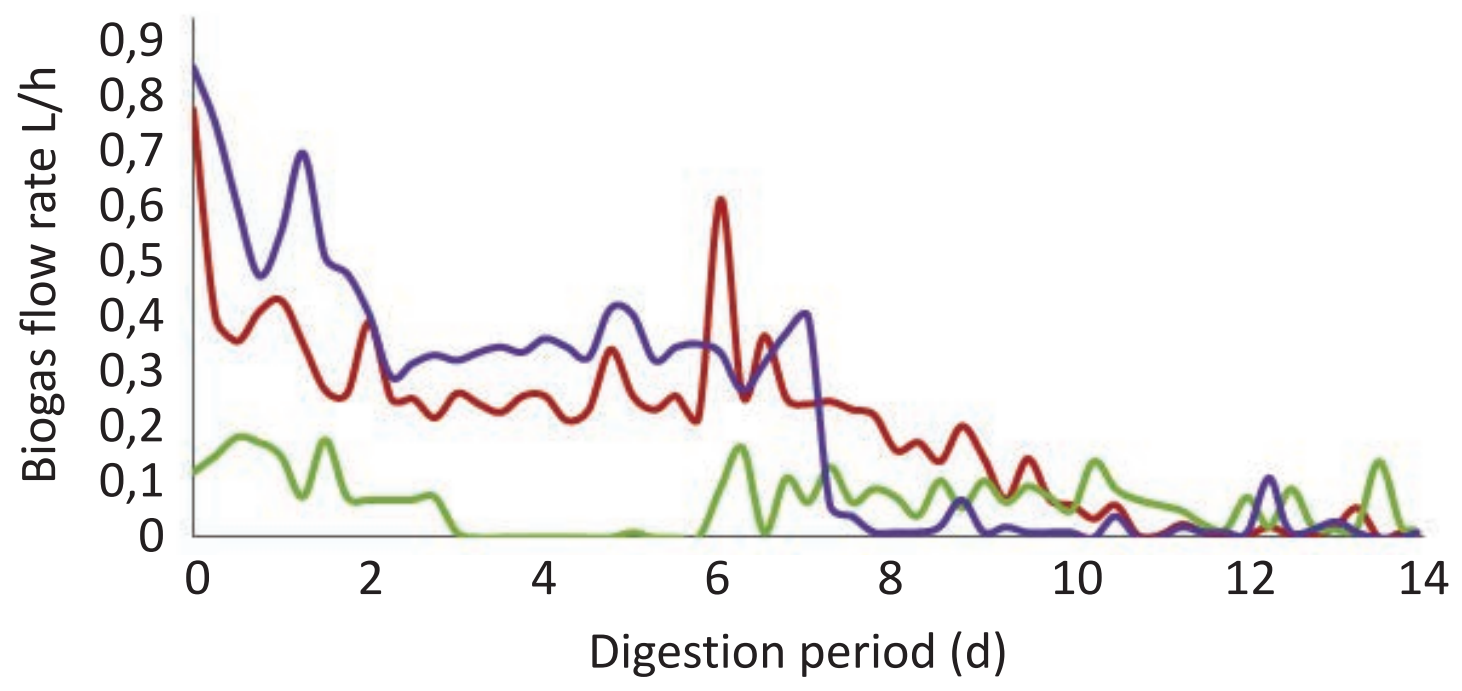

Figure 3 - Daily Biogas Production.

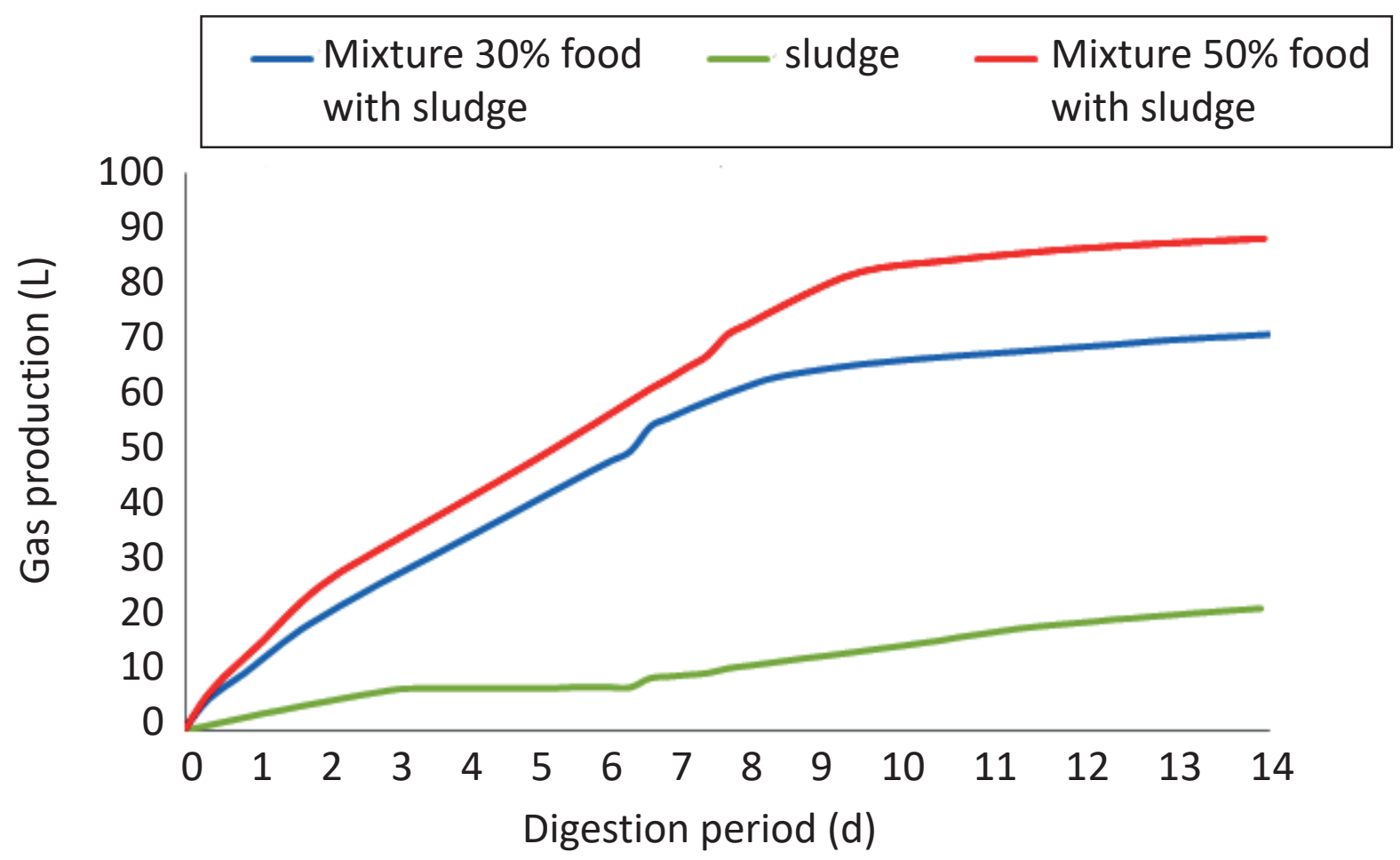

Figure 4 - Cumulative Biogas Production. 
Table 3 - Comparisons of biogas production from co-digestion of various food waste and sewage sludge in mesophilic conditions.

\begin{tabular}{|c|c|c|c|}
\hline Reference & Food Residues & $\begin{array}{c}\text { SPG } \\
(\mathrm{I} / \mathbf{g} \text { VS) }\end{array}$ & $\begin{array}{c}\text { Methane } \\
\mathrm{CH}_{4} \%\end{array}$ \\
\hline This study & SS only & 0.09 & n.r \\
\hline Food waste Source & $26.5 \%$ Food waste, $73.5 \%$ SS & 0.112 & 48 \\
\hline (University Canteen) & $34 \%$ Food waste, 66 \% SS & 0.184 & 55 \\
\hline (CABBAl et al., 2013) & $100 \%$ WAS & 0.39 & 64 \\
\hline Food waste Source & $58.5 \%$ Food waste, $41.5 \%$ WAS & 0.62 & n.r \\
\hline (Canteen, Supermarket, Household) & $25 \%$ Food waste, $75 \%$ WAS & 0.45 & 53.8 \\
\hline $\begin{array}{c}\text { (CAVINATO et al., 2013) } \\
\text { Food waste Source } \\
\text { (Canteen, Supermarket, Household) }\end{array}$ & $\begin{array}{c}100 \% \text { WAS } \\
50 \% \text { Food waste, } 50 \% \text { WAS }\end{array}$ & $\begin{array}{l}0.15 \\
0.34\end{array}$ & $\begin{array}{c}61.8 \\
60\end{array}$ \\
\hline $\begin{array}{c}\text { (NIELFA; CANO; } \\
\text { FDZ-POLANCO, 2015) } \\
\text { Synthetic OFMSW }\end{array}$ & $100 \%$ biological sludge & 0.27 & 60 \\
\hline $\begin{array}{l}\text { (ZUPAŇCICA; URANJEK- } \\
\text { ŽEVARTB; ROŠA, 2008) } \\
\text { Domestic refuse (swill) }\end{array}$ & $\begin{array}{c}80 \% \text { Food waste, } \\
20 \% \text { biological sludge }\end{array}$ & 0.22 & n.r \\
\hline
\end{tabular}

SS : sewage sludge ; WAS : Waste of Activated Sludge, OFMSW: Organic fraction municipal solid waste

The Biogas yields of all experiments are shown in Table 3. Within the mesophilic digestion conditionthe biogas yield increased by $19 \%$ with the addition of $26.5 \%$ food residues to the totaIVS. (Cabbai, et al. 2013)reported that within food residues addition by $25 \%$ biogas yield increased by $13 \%$, intrinsic ally. These trends of biogas yields could be explained by higher degrading capability and methanogenic activity as shown in Figure 3. (KIM, 2003) has reported that the important factors for the enhanced performance of co-digestion are the additional organic carbon, nutrient balance and adequate mixing ratio.
Additional carbon source supplied by food residues create preferable environment for the growth and activity of a naerobic mic ro orga nism.

\section{Conclusion}

The experiment has shown that the codigestion of sewage sludge mixed with food waste had a distinct positive effect on biogas and methane yields by keeping the adequate fraction of food waste. As expected using food waste substra tes positively affects biogas and 
methane production, with a signific ant increases biogas yield in the range of $20 \%$ to $30 \%$, and an increase in the range of 50 to $60 \%$ in removable VS by increase the food waste substrate in the range of $26 \%$ to $35 \%$. Biogas cumula tive production during co-digestion of food waste with sludge inc reases notably when inc reasing the food waste to sewage sludge ratio.

\section{References}

ABATZOGLOU, N., 2009. A review of biogas purification processes. Biofuels, Bioproducts and Biorefining, vol. 3, no. 1, pp. 42-71.

ÁlVAREZ, J.A.,2010. A methodology for optimising feed composition for anaerobic co-digestion of agroindustrial wastes. Bioresource technology, vol. 101, no. 4, pp. 1153-1158.

AMANI, T., 2010. Anaerobic digestion from the viewpoint of microbiological, chemical, and operational aspects-a review. Environmental Reviews, vol. 18, no. NA, pp. 255-278.

BORGHI, D., 1999. Hydrolysis and thermophilic anaerobic digestion of swage sludge and organic fraction of municipal solid waste. Bioprocess Eng., vol. 20, no. 6, pp. 553-560.

BRAUN, R., 1982. Biogas - Methangärung organischer Abfallstoffe. Vienna: Springer.

CABBAI, V., BALLICO, M., ANEGGI, E., GOI, D. BMP tests of source selected OFMSW to evaluate anaerobic codigestion with sewage sludge. Waste Manag., 2013: 1626-1632.

CAVINATO, C., BOLZONELLA, D., PAVA, P., FATONE, F. and CECCHI, F., 2013. Mesophilic and thermophilic anaerobic co-digestion of waste active sludge and source sorted biowaste in pilot and full scale reactors. Renew. Energy, pp. 260-265.

CHEN, Y., 2008. Inhibition of anaerobic digestion process: a review. Bioresource technology, vol. 99, no. 10 , pp. $4044-4064$.

\section{Acknowledgements}

The a uthorswould like to thank GIZ Water Portfolio for allowing using DISM project findings for this public ation. Thanks to DISM project colleaguesfor their technical support and to Mu'ta Almazar WWTP staff and University of Muta for their cooperation.

CRAWFORD, G., 2010. Energy efficiency in wastewater treatment in North America: a compendium of best practices and case studies of novel approaches. Water Environment Research Foundation.

CRISTANCHO, D.E., 2006. Study of the operational conditions for anaerobic digestion of urban solid wastes. Waste management, vol. 26, no. 3, pp. 546-556.

DEMIREL, B. et al., 2007. Microbial community dynamics of a continuous mesophilic anaerobic biogas digester fed with sugar beet silage. Engineering in Life Sciences, pp. 390-398.

EPA, CHP., 2007. Opportunities for and benefits of combined heat and power at wastewater treatment facilities. EPA-430-R-07-003, no. 6.

ESPINOZA-ESCALANTE, F.M., 2009. Anaerobic digestion of the vinasses from the fermentation of Agave tequilana Weber to tequila: the effect of $\mathrm{pH}$, temperature and hydraulic retention time on the production of hydrogen and methane. Biomass and bioenergy, vol. 33, no. 1, pp. 14-20.

GERARDI, M.H., 2003. The microbiology of anaerobic digesters. John Wiley \& Sons.

GUJER, W., 1983. Conversion processes in anaerobic digestiono. Water science and technology, vol. 15, no. 8-9, pp. 127-167.

GÜNGÖR-DEMIRCI, G., 2004. Effect of initial COD concentration, nutrient addition, temperature and microbial acclimation on anaerobic treatability of broiler and cattle manure. Bioresource technology, vol. 93, no. 2, pp. 109-117. 
HEO, N.H., 2004. Effects of mixture ratio and hydraulic retention time on single-stage anaerobic co-digestion of food waste and waste activated sludge. Journal of Environmental Science and Health, Part A, pp. 17561766.

KIM, M., 2003. Hydrolysis and acidogenesis of particulate organic material in mesophilic and thermophilic anaerobic digestiono. Environmental technology, vol. 24, no. 9, pp. 1183-1190.

KROISS, H., 2015. Einflussfaktoren auf die anaeroben biologischen Abbauvorgänge. Springer.

LAGERKVIST, A., 2012. The effects of substrate pretreatment on anaerobic digestion systems: a review. Waste Management, vol. 32, no. 9, pp. 1634-1650.

LEBUHN, M., BERNHARD, M. and EFFENBERGER, M., 2014. Agricultural biogas production in Germany-from practice to microbiology basics. Energy, Sustainability and Society, vol. 4, no. 10.

LINDMARK, J., 2014. Effects of mixing on the result of anaerobic digestiono. Renewable and Sustainable Energy Reviews, vol. 40, pp. 1030-1047.

LIU, C-F., 2008. Prediction of methane yield at optimum $\mathrm{pH}$ for anaerobic digestion of organic fraction of municipal solid waste. Bioresource Technology, vol. 99, no. 4, pp. 882-888.

LIU, T., 2002. Ammonia inhibition on thermophilic aceticlastic methanogens. Water Science and Technology, vol. 45, no. 10, pp. 113-120.

MATA-ALVAREZ, J., 2002. Biomethanization of the organic fraction of municipal solid wastes. IWA publishing.
MOUSDALE, D.M.,2008. Biofuels: biotechnology, chemistry, and sustainable development. CRC press.

MWI., 2015. Annual Report: domestic wastewater sector. Amman, Jordan: Ministry of Water and Irrigation.

NIELFA, A., CANO, R. and FDZ-POLANCO, M., 2015. Theoretical methane production generated by the co-digestion of organic fraction municipal solidwaste and biological sludge. Biotechnol. Rep., pp. 14-21.

OECHSNER, H., 2009. Was kann die Hydrolyse bei der Biogasvergärung leisteno. VDI-Ber, pp. 37-46.

RITTMANN, B.E., 2012. Environmental biotechnology: principles and applications. Tata McGraw-Hill Education.

SEYFRIED, C.F. et al., 2011. Abundance of trace elements in demonstration biogas plants. Biosystems Engineering, pp. 57-65.

SME., 2010. Standard Methods for the Examination. Washington: APHA AWWA WEF.

TUROVSKIY, I.S., 2006. Wastewater sludge processing. John Wiley \& Sons.

WEILAND, P., 2010. Biogas production: current state and perspectives. Applied microbiology and biotechnology, vol. 85, no. 4, pp. 849-860.

ZUPAN ${ }^{\vee} \mathrm{Cl}^{\vee} \mathrm{CA}$, D.G., URANJEK-ŽEVARTB, N. and ROŠA, M., 2008. Full-scale anaerobic co-digestion of organic waste and municipal sludge. Biomass Bioenergy, pp. 162-167. 



\section{Improving Global Wash Sustainability}

Graydon, R.C. ${ }^{1}$

1Department of G lobal Hea lth, College of Public Hea Ith, University of South Florida, USA. Corresponding author: rgraydon@health.usf.edu

\section{Abstract}

This paper provides a review of the health and economic effects of water, health, and sanitation (WASH) infrastruc ture. G lobal stra tegies to inc rease WASH infrastruc ture and the current coverage levels a re discussed revealing mixed progress and disparities particularly in rural areas. Many rural WASH infra struc ture interventions have failed or operate significantly below intended capacity demonstrating the need for a grea ter foc us on susta ina bility. This paper defines susta ina bility in the context of WASH infrastructure and describes the tools used to assess susta inability of water projects. Finally, this paper concludes with specific recommenda tions for governments, nongovemmental organizations, and donors to improve the susta inability of water projects and ultimately the development of communities.

Keywords: susta inable development goals, water, sa nitation, hygiene, global health, development.

\section{Introduction}

Depending on one's point of view and situation, water, sanitation, and hygiene (WASH) servic esconta in the ability to sustain healthy life and positive development (NAUG ES; STRAND, 2013; WHO, 2012) or, on the other hand, developmental determent and cause of one's suffering and untimely death (FERDO US et al., 2013; GUERRANT; DEBOER; MOORE; SC HARF; LIMA, 2013; HASANAIN; J AMSIAH; ZALEHA; AZMI; MOHAMMED, 2012; PRÜSS-USTÜN et al., 2014). Susta inable WASH services is crucial to ensure its effectiveness and long-term be nefits (BO ULENOUAR; SC HWEITZRR; 
LOCKWOOD, 2013; KWANG WARE; MAYO; HOKO, 2014; MC CONVILLE; MIHELCIC, 2007; RO NDI; SO RLINI; COLLIVIG NARELLI, 2015; SC HWEITZR; MIHELCIC, 2012).

\section{Health and Economic Consequences}

The lack of adequate WASH services poses the paramount threat to the health and development of the global community. Improper WASH causes a variety of diseases including diarrheal disea ses, dracunculia sis, and lymphatic filariasis through the ingestion of pathogenic orga nisms in drinking water and unsanitary soil with pathogens such as Entamoeba histolytic a, Giardia duodenalis, and Asc a ris lumbric oid es(G EERS C HILDERS; PALMIERI; SAMPSO N; BRUNET, 2014). In terms of effect on health, ina dequate WASH was estimated to be the cause of 842,000 diarrhea deaths globally representing $58 \%$ of dia rrheal disea ses in 2012 (PRÜSS-USTÜN et al., 2014), which is a p proxima tely 2,300 deaths per day. An estimated 361,000 deaths a mong children under five years of age, representing 5.5\% of deaths in that age group, could have been prevented with proper WASH. Persistent diarrhea among children is associated with malnutrition, cognitive impairment (FERDOUS et al., 2013; HASANAIN et al., 2012), and an inc reased risk of developing o besity la ter in life (G UERRANTet al., 2013). Proper WASH is crucial to a healthy life and development.
Conceming effect on development, the water crisis ranks number one in terms of global societal impact and number eight in terms of like lihood to occur within the next ten years (WEF, 2015). Lack of a clean drinking water source poses such a great economic threat due to the resulting morta lity, morbidity, and disability by rendering a person unable to work and due to the enormous quantity of time demanded to haul water. Women and children bear the majority of the water hauling responsibilities with the largest group spending more than 30 minutes on a single trip tota ling an estimated 140 million hours every day hauling water (UNIC EF; WHO, 2015). This da ily time demand causes obvious conflict with development by reducing time invested in an income-generating job, caring for fa mily members, or attending school. However, through improved water sources and, thus, reduced hauling times, children's school attendance has signific antly increased in multiple developing countries (NAUGES; STRAND, 2013). Investing in WASH infra structure also has a high rate of retum with an estimated US\$ 4 economic retum on every US $\$ 1$ spent by keeping people healthy and productive (WHO, 2012). Investing in adequate WASH infrastruc ture would greatly reduce this burd en of disease and provide enormous economic benefits.

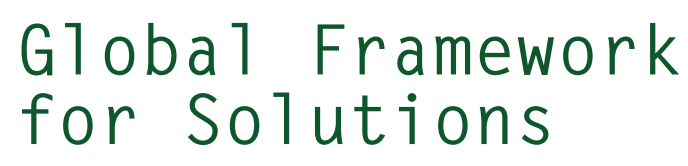

Clean water and sa nitation is a building block to global public health 
and development as evidenced by its inclusion in the Millennium Development Goals (MDGs) and now the Sustainable Development Goals (SDGs). On September 25,2015 , the member sta tes of the United Nations celebrated the beginning of a new era of cooperation in development with the adoption of the SDG s for 2030 (UNITED NATIONS, 2015). The SDG s a re the post-2015 goals that follow the MDGs, which was the framework of development between 2000 to 2015 (UNITED NATIONS, 2000). The MDGs contained eight broad goals of which MDG 7c wasto halve the proportion of people without susta ina ble access to safe drinking water and basic sa nitation between 1990 and 2015. Well ahead of the 2015 deadline, the goal for improved drinking water was announced as being met and surpassed in 2010 (UNICEF; WHO , 2012). However, this a nno unc ement was criticized as being overly optimistic when the microbial water quality was considered revealing improved water supplies with unsa fe levels of coliforms in several countries ra ising serious concems about the safety of the improved water so urc es (BAUM; KAYSER; STAUBER; SOBSEY, 2014; SHA HEED; ORG ILL; M O NTG O MERY; J EULAND; BROWN, 2014). This suggests new efforts are needed to ensure both qua ntity and quality of improved water sources.

When the final MDGs assessment report was published in 2015, it boasted numerous signific ant improvements but also revea led areas of needed improvement (UNICEF; WHO, 2015). Conceming drinking water, key positive highlights were that $91 \%$ of the global population was measured asusing an improved water source and 2.6 billion people gained access to an improved water source since 1990. On the other hand, an una chieved goal was that the Cauca sus and Central Asia, Northern Africa, Oceania, and Sub-Saharan Afric a regions did not a chieve their regional coverage goals. Specific disparities were noticed as $96 \%$ of the global urban population uses improved drinking water sources compared to only $84 \%$ of the global rural population. Stated a nother way, 8 out of 10 people without an improved drinking water source live in rural a reas. As of the report's publishing, 663 million people still lack an improved drinking water so urce. Despite the global increase of improved rural water systems, evidence shows that $30-40 \%$ of these systems fail or operate signific antly below intended capacity demonstrating the need for a greater fo cus on susta ina bility (LOCKWOOD; SMITS; SC HO UTEN; MORIARTY, 2010).

Conceming sanitation, the target of $77 \%$ improved sanitation coverage was missed by a lmost 700 million people (UNICEF; WHO, 2015). Geographic disparities a lso exist in improved sanitation coverage as $82 \%$ of urban population was reported to have access to an improved sanitation facility compared to only $51 \%$ of rural population. Of those who lack access to a improved sanitation facility, 7 out of 10 live in rural a reas, and 9 out of 10 people who practice open defecation live in rural a reas. Although this ta rget was not a chieved, a highlight is that 2.1 billion people gained access to improved 
sanitation since 1990. However, 2.4 billion people still lack access to an improved sa nita tion facility. Based on this report, the SDGs were created to continue this progress.

There are 17 SDG s set to be achieved by 2030. SDG six is "Clean Water and Sanitation." Addressing drinking water and sanitation, target 6.1 is to "achieve universal and equitable access to safe and affordable drinking waterfor all" and target 6.2 is to "achieve access to a dequate and equitable sanitation and hygiene for all and end open defecation..." (UNITED NATIONS, 2015). There a re several other targets under this goal but these targets are relevant for the scope of this paper.

\section{Interventions: Focus on Sustainability}

The goal in providing WASH servic es is to ensure the entire a rray of benefits while minimizing its c osts over time. Susta ina ble development has been defined as "development that meets the needs of c urrent generations without compromising the ability of future generations to meet their own needs" (WCED, 1987, p. 43). Thus, susta inable WASH infrastructure is the continued delivery of c lea $n$ d rinking water and sanitation without resource depletion. How to best ensure sustaina bility is highly debated but one recurring theme is dema nd-d riven a p proach (DAYAL; VAN WIJ K; MUKHERJ EE, 2000; KWANG WARE et al.,
2014; MADRIG AL; ALPÍZAR; SC HLÜTER, 2011; MONTG O MERY; BARTRAM; ELIMELEC $H$, 2009).

\section{Demand-driven approach}

Demand-driven approach is the principle that local communities a re active in the decisions that affect their communities and the consideration that different user groups may desire different interventions (DAYAL et al., 2000; MADRIG AL et al., 2011). Evidence has revealed that community partic ipation in the design, financing, and administration signific antly inc rea ses project susta ina bility (BARNES; ASHBO LT; ROSER; BROWN, 2014; MADRIG AL et a I., 2011; MARKS; KO MIVES; DAVIS, 2014). Depth, not breadth, of resident's involvement in the planning process is associated with water point sustaina bility. Project outc omes a re better when the community participates more in management decisions and less fa vorably with technic al decisions (MARKS et al., 2014).The opposite of demand-driven approach is the supply-driven approach in which communities a re not included in the decision-making process but a re simply observers. Supply-driven approach, a paternalistic behavior, perpetuates cyclic al poverty and ineffective interventions (CORBEIT; FIKKERT, 2014). To improve susta ina bility outc o mes, susta ina bility frameworks and assessment tools have been developed to guide and measure sustainable development. 


\section{Sustainabi 1 ity}

assessment tools

Dozens of susta ina bility a ssessment tools have been made to improve the susta inability of development projects addressing all stages of the planning and life cycle utilizing various susta ina bility models. The susta ina bility a ssessment tools conta in a litany of questions based on its specific model of susta ina bility fra mework rating the likelihood of success and susta ina bility. Sc hweitzer, G rayson, and Lockwood (2014) performed a review of 191 susta ina bility a sse ssment to o ls eva lua ting the context of their use and their strengths and weaknesses. Their review should be used as a resource in choosing the proper tool for the a nticipated project. Besides these susta inability assessment tools, other specific recommendations exist forva rious groups that provide WASH infrastruc ture.

\section{Recommendations for governments}

According to Boulenouar and Schweitzer(2015), governments should develop an infrastructure asset management (IAM) stra tegy partic ula rly for rural water supply where parastatal corporations and community management organizations manage the majority of WASH infra structure. IAM in the WASH sector refers to the physic al components of water systems as well as the decisions and processes to assure services. The government should also provide template contracts between service authorities and service providers and ensure the financing of WASH infra struc ture. Lastly, government should provide the technical support and training to both service a uthorities and service providers. Evidence suggests that access to post-construc tion support services g rea tly a ffec ts susta ina bility outc omes (FERDO US et al., 2013; MARKS et al., 2014). Although govemment financing is suggested, strong government subsidies have many drawbacks and may not appropriate for every project (GOMES; HELLER; CAIRNCROSS; DOMENÈC H; PENA, 2014). A more effective financing method to the financial recovery and func tiona lity of installed water systems is the collection of a userfee (FOSTER, 2013; MONTG O MERY et a I., 2009).

\section{Recommendations for non-governmenta 1 organizations and donors}

Boulenouar and Sc hweitzer (2015) suggest that non-govemmental orga niza tions (NGOs) can improve the susta inability of WASH infrastructure by supporting local governments to inventory the water assets in their jurisdiction and to implement the national IAM guidelines. Donors should also support the govemment by providing technical and financial support, ensuring all the water assets a re registered, and sharing pertinent information. Many studies have demonstrated that the use 
of financial tools are benefic ial to project susta ina bility (BOULENO UAR et a l., 2013; J ONES, 2013; KWANG WARE et al., 2014; MADRIGAL et al., 2011; RONDI et al., 2015; SCHWEITZR; MIHELCIC, 2012). These three levels of organizations working together can provide greater accountability and local support, which increases project susta ina bility (J ONES, 2013; SMITS; RO J AS; TAMAYO, 2013; WINTERS, 2010).

\section{Conclusion}

In order to achieve SGD six and to reduce the rates of death and disease as well as its associated economic

\section{References}

BARNES, R., ASHBOLT, N., ROSER, D. and BROWN, P., 2014. Implementing sustainable water and sanitation projects in rural, developing communities. Waterlines, vol. 33, no. 1, pp. 71-88. https://doi. org/10.3362/1756-3488.2014.008

BAUM, R., KAYSER, G., STAUBER, C. and SOBSEY, M., 2014. Assessing the microbial quality of improved drinking water sources: Results from the Dominican Republic. The American Journal of Tropical Medicine and Hygiene, vol. 90, no. 1, pp. 121-123. https:// doi.org/10.4269/ajtmh.13-0380

BOULENOUAR, J. and SCHWEITZER, R., 2015. Infrastructure asset management for rural water supply. Avaiable from: http://www.ircwash.org/ resources/infrastructure-asset-management-ruralwater-supply.

BOULENOUAR, J., SCHWEITZER, R. and LOCKWOOD, H., 2013. Mapping sustainability assessment tools to support sustainable water and sanitation service delivery. IRC International Water and Sanitation Centre, The Hague, the Netherlands. Avaiable from: http://www.ircwash.org/sites/default/files/2013_ wp6_sustainabilityassessmenttools.pdf consequences, WASH services and infrastructure must be built especially in the a reas where it is lacked most and disease is most prevalent, namely rural areas. Simply providing WASH infrastruc ture (i.e. supply-d riven demand) to communities in need has resulted in inoperable systems and the perpetuation of poverty foiling development efforts(Loc kwood et al., 2010). Therefore, through the recommendations of demand-driven approach and usage of susta inability a ssessment tools, new WASH infrastructure can provide lasting health benefits and support the economic development of the recipient communities in both rural and urban areas.

CORBETT, S. and FIKKERT, B., 2014. When Helping Hurts: How to Alleviate Poverty Without Hurting the Poor... and Yourself (New Edition). Chicago, IL: Moody Publishers.

DAYAL, R., VAN WIJK, C. and MUKHERJEE, N., 2000. Methodology for participatory assessments with communities, institutions, and policymakers : linking sustainability with demand, gender, and poverty, no. 20831, pp. 1-120. The World Bank. Avaiable from: http://documents.worldbank.org/curated/ en/2000/03/693353/methodology-participatoryassessments-communities-institutions-policymakerslinking-sustainability-demand-gender-poverty

FERDOUS, F. et al., 2013. Severity of diarrhea and malnutrition among under five-year-old children in rural Bangladesh. The American Journal of Tropical Medicine and Hygiene, vol. 89, no. 2, pp. 223-228. https://doi.org/10.4269/ajtmh.12-0743

FOSTER, T., 2013. Predictors of sustainability for community-managed handpumps in Sub-Saharan Africa: Evidence from Liberia, Sierra Leone, and Uganda. Environmental Science \& Technology, vol. 47, no. 21, pp. 12037-12046. https://doi.org/10.1021/ es402086n 
GEERS CHILDERS, K.A., PALMIERI, J., SAMPSON, M. and BRUNET, D., 2014. Prevalence of gastrointestinal parasites in children from Verón, a rural city of the Dominican Republic. Research and Reports in Tropical Medicine, vol. 5, pp. 45-53. https://doi. org/10.2147/RRTM.S64948

GOMES, U., HELLER, L., CAIRNCROSS, S., DOMENÈCH, L. and PENA, J., 2014. Subsidizing the sustainability of rural water supply: the experience of the Brazilian rural rainwater-harvesting programme. Water International, vol. 39, no. 5, pp. 606-619. https:// doi.org/10.1080/02508060.2014.951255

GUERRANT, R., DEBOER, M., MOORE, S., SCHARF, R. and LIMA, A., 2013. The impoverished gut-a triple burden of diarrhoea, stunting and chronic disease. Nature Reviews Gastroenterology and Hepatology, vol. 10, no. 4, pp. 220-229. https://doi.org/10.1038/ nrgastro.2012.239

HASANAIN, F., JAMSIAH, M., ZALEHA, M., AZMI, M.T. and MOHAMMED, A., 2012. Association between drinking water sources and diarrhea with malnutrition among kindergarten's children in Baghdad City, Iraq. Malaysian Journal of Public Health Medicine, vol. 12, no. 1, pp. 45-48.

JONES, S., 2013. How can INGOs help promote sustainable rural water services? An analysis of WaterAid's approach to supporting local governments in Mali. Water Alternatives, vol. 6, no. 3, pp. 350-366.

KWANGWARE, J., MAYO, A. and HOKO, Z., 2014. Sustainability of donor-funded rural water supply and sanitation projects in Mbire district, Zimbabwe. Physics and Chemistry of the Earth, Parts A/B/C, pp. 76-78, pp. 134-139. https://doi.org/10.1016/j. pce.2014.10.001

LOCKWOOD, H., SMITS, S., SCHOUTEN, T. and MORIARTY, P., 2010. Providing sustainable water services at scale. IRC and Aguaconsult. Avaiable from: http://www.ircwash.org/sites/default/files/ Lockwood-2010-Providing.pdf

MADRIGAL, R., ALPÍZAR, F. and SCHLÜTER, A., 2011. Determinants of performance of community-based drinking water organizations. World Development, vol. 39, no. 9, pp. 1663-1675. https://doi.org/10.1016/j. worlddev.2011.02.011

MARKS, S., KOMIVES, K. and DAVIS, J., 2014. Community participation and water supply sustainability: Evidence from handpump projects in rural Ghana. Journal of Planning Education And Research, vol. 34, no. 3, pp. 276-286. https://doi.org/10.1177/0739456X14527620
McCONVILLE, J.R. and MIHELCIC, J.R., 2007. Adapting life-cycle thinking tools to evaluate project sustainability in international water and sanitation development work. Environmental Engineering Science, vol. 24, no. 7, pp. 937-948. https://doi.org/10.1089/ ees.2006.0225

MONTGOMERY, M.A., BARTRAM, J. and ELIMELECH, M., 2009. Increasing functional sustainability of water and sanitation supplies in rural Sub-Saharan Africa. Environmental Engineering Science, vol. 26, no. 5, pp. 1017-1023. https://doi.org/10.1089/ees.2008.0388

NAUGES, C. and STRAND, J., 2013. Water hauling and girls' school attendance: Some new evidence from Ghana. The World Bank. Avaiable from: http://elibrary. worldbank.org/doi/abs/10.1596/1813-9450-6443

PRÜSS-USTÜN, A. et al., 2014. Burden of disease from inadequate water, sanitation and hygiene in low- and middle-income settings: A retrospective analysis of data from 145 countries. Tropical Medicine \& International Health, vol. 19, no. 8, pp. 894-905. https://doi.org/10.1111/tmi.12329

RONDI, L., SORLINI, S. and COLLIVIGNARELLI, M.C., 2015. Sustainability of water safety plans developed in Sub-Saharan Africa. Sustainability, vol. 7, no. 8, pp. 11139-11159. https://doi.org/10.3390/su70811139

SCHWEITZER, R., GRAYSON, C. and LOCKWOOD, H., 2014. Mapping of Water, Sanitation, and Hygiene Sustainability Tools. IRC and Aguaconsult. Avaiable from: http://www.ircwash.org/sites/default/files/ triple-s_wp10mappingofwashsustainabilitytools.pdf

SCHWEITZER, R.W. and MIHELCIC, J.R., 2012. Assessing sustainability of community management of rural water systems in the developing world. Journal of Water, Sanitation and Hygiene for Development, vol. 2, no. 1, p. 20. https://doi.org/10.2166/washdev.2012.056 SHAHEED, A., ORGILL, J., MONTGOMERY, M., JEULAND, M. and BROWN, J., 2014. Why "improved" water sources are not always safe. Bulletin of the World Health Organization, vol. 92, pp. 283-289. https:// doi.org/http://dx.doi.org/10.2471/BLT.13.119594

SMITS, S., ROJAS, J. and TAMAYO, P., 2013. The impact of support to community-based rural water service providers: Evidence from Colombia. Water Alternatives, vol. 6, no. 3, pp. 384-404. 
UNICEF, WHO, 2012. Millennium Development Goal drinking water target met. Avaiable from: http:// www.who.int/mediacentre/news/releases/2012/ drinking_water_20120306/en/. Access: Oct. 2015.

UNICEF, WHO, 2015. Progress on Sanitation and Drinking Water: 2015 Update and MDG Assessment. United States of America: UNICEF. Avaiable from: http://www.unicef.org/publications/index_82419.html

UNITED NATIONS, 2000. Millennium Summit. Avaiable from: http://www.un.org/en/events/pastevents/ millennium_summit.shtml. Access: Oct. 2015.

UNITED NATIONS, 2015. Sustainable Development Goals. Avaiable from: http://www.un.org/ sustainabledevelopment/sustainable-developmentgoals/. Access: Oct. 2015.

WHO, 2012. Global costs and benefits of drinkingwater supply and sanitation interventions to reach the MDG target and universal coverage. Geneva, Switzerland: WHO Document Production Services. Avaiable from: http://www.who.int/water_sanitation_ health/publications/2012/global_costs/en/
WINTERS, M.S., 2010. Accountability, participation and foreign aid effectiveness. International Studies Review, vol. 12, no. 2, pp. 218-243. https://doi. org/10.1111/j.1468-2486.2010.00929.x

WCED, 1987. World Commission on Environment and Development. Our Common Future (p. 300). Oxford, United Kingdom: Oxford University Press. Avaiable from: http://www.un-documents.net/ourcommon-future.pdf

WEF, 2015. World Economic Forum. The Global Risks 2015 Report. Avaiable from: http://reports.weforum. org/global-risks-2015/. Access: October 2015. 


\section{System of Sustainability Indicators Applied in River Basin Management}

Ba talhã o, A.C.S. ${ }^{1}$, Teixeira, D. ${ }^{1}$

'Post-Graduate Prograns in Environmental and Sa nitary Engineering and Environmental Sciences - PPEAS- CIAMB, Fed eral University of G oiás - UFG.

Corresponding author: andre.ciamb.ufg@gmail.com

\section{Abstract}

The historic al context of the ind ic a tors clearly shows their complementary role in the decision-making processes, seeking to make perceptible a current condition resulting from a historical process of past practices and actions, reflecting the reflexes of previous planning. This tool can be used for river basin planning and management, including monitoring, assessment and reporting. The general a im of this research is to suggest a model of sustaina bility indic a tors for the PCJ basin committees management, as an auxiliary tool for assessing the region's susta inability level. The research to be developed has qua ntitative and qua lita tive characteristic s, characterized as a mixed method. The Preliminary findings of this research point to the need for institutional innovations and their formalization and emancipation before public management, with the creation and performance of partic ipatory procedures prescribed in specific laws, such as in the area of water resources, where the participation of multi-stakeholders through the Watershed Committees represents a signific ant breakthrough for good govemance. It is necessary to consolidate the articulation between institutions at the municipal level so that the dimensions of susta inability are treated in a fair and proactive way, so that progress towards regional susta inable development is possible.

Keywords: susta ina bility ind ic a tors, river basin management, PCJ basin committees. 


\section{Introduction}

Susta ina bility supports a universa lly shared common vision of progress towards a just, sec ure and susta inable soc iety for huma nity. This concept recognizes not only the need for environmental protection but also the urgency to improve the quality of life through strategies that create socio-economic growth and address a wide range of cross-c utting issues. While there is a growing consensus that a more susta ina ble soc iety embrac es all ind ivid ua Is, opinions about what susta ina bility means and how that can be achieved are diverse (ALSHUWAIKHAT et al., 2017).

In the monitoring of regional enviro nmental and susta ina bility issues one of the main goals is to support decisionmaking processes, thus improving regional susta ina bility ma na gement and a chieving better development results. In the face of heterogeneity of methods and tools for mea suring susta ina bility, ind ic a tors a lmost a lwa ys play a fundamental role. Sustainable Indicators a re one possible way of ensuring that sustaina bility issues a re being consistently and transparently integrated into sector activities on a local, regional and national scale. Indicators provide substantial susta ina bility performance mea surement, reporting and transparency to stakeholders (RAMOS, 2009). According to Santos (2004), regard less of the objectives or the planned site, this stra tegy requires the specialization of a broad set of data that needed to be compared, overlapped and evaluated in a holistic way.

The historic al context of the ind ic a tors clearly shows their complementary role in the decision-making processes, seeking to make perceptible a current condition resulting from a historic al process of past practices and actions, reflecting the reflexes of previous planning. When an ind ic a tor is a na lyzed, its c urrent portra it is viewed from the historical perspective, sustaining the ability to project future trendsand conditions to develop ways to monitor and measure its temporal behavior (BATALHÃO; TEIXEIRA, 2017).

Susta ina bility ind ic a to rs a re essentia I tools to ensure the identific ation of a comprehensive strategiesand realistic way of a ssessing and improving sustainability. This tool can be used for river basin planning and management, including monitoring, assessment and reporting. Also, ind ic a tors are important assessment tools to id entify social needs and contribute to public planning and management. However, the properuse of indic ators in the public management is still a methodological and politic al challenge with rather vague guidelines in many scales. Few studies explored the different potential uses and impacts of indic a tors a s complementary tool to decision-making in water management and planning processes (WU; LEONG, 2016).

The development of strategies related to the monitoring of sustainable development requires data and information of va rious natures. Indic a tors fulfill this role, with qua ntita tive and qualita tive attributions, as they qua ntify and simplify complex phenomena and realities to a manageable amount of significant information to foment the dec ision-making process (HARMANCIOGLU; BARBAROS; CEINKAYA, 2013).

At regional scale, planning for the proposal of sustainable development is more comprehensive and robust, by the size of the temitory and by the number of key actors, which facilita tes the identific ation 
of problems, community demands and local knowledge, with grea ter possib ilities for partic ipation. Mic kwitz et al. (2006) emphasizes that on a regional sc a le any attempt at metho dologic al genera liza tion can be questioned because the problems are different and need customized tools.

Meet the susta ina bility development demands are critical to a renewal and ma intenance of practic es that enable an effective and secure flow of information to strengthen the most important decision-making processes. From the management of water and the environment we can perceive multiple relationships and interactions and their regional interests. Therefore, it is nec essary to promote a ssessments and work with findings to project trends. This is justified by the increasing demand for evalua tion systems using ind ic a tors that capture the subjectivities of the research object and make them objective.

In this perspective, this study c an also assist river basin committees and public management, serving as a reference for the development and maintenance of public polic iesaimed at basin susta inability, considering the use of water, its economic importa nce, environmental degradation, and the level of productivity, a mong its multiple dimensions. This contributes to broadening the vision of all the actors involved in the management of the basins and the municipalities that constitute these spaces, generating new discussions about the factors that may enable a way to promote development, not forgetting the social and environmental demands, leaving behind the concept that development is only chained to economic growth. Scientifically, its relevance is in the development and reproducibility of the methodology, considering possible adaptations to the regions of a nalysis, and can serve as a starting point for future work.

For this, the research's main issue should answer the question:

- Is it possible to find ways to evaluate the sustainability level of Piracicaba, Capivari and J undiaí (PCJ) basin region in Brazil using the Basin Plan as a reference and involving key stakeholders (decision makers, basin committees, organized civil society, municipal/ state/federal agencies, consultancies and other users) based on a set of indicators which considers the characteristics of susta inability and meets the wishes and demands of the stakeholders, to improve the management of the subjects related to susta inable development?

In a ddition, confirm or falsify a ma in hypothesis which is:

- It is possible to develop a model (structure) of indicators based on the participation of the key stakeholders, which can serve as an evaluation tool for the elaboration of a situational pic ture of the object, and also as a complementary tool for the management of susta inable development within the framework of PCJ basin.

The general a im of this research is to suggest a model of susta ina bility indic a tors for the PCJ basin committees the management, as an a uxiliary tool for assessing the region's susta ina bility level. In order to achieve the major goal, the research plan will be developed in five tasks that a re shortly described:

To provide an overview of the challenges and demands present in the literature and associate them with the main 
stages of elaboration and implementation of susta ina bility ind ic a tors.

- To analyze the main models of systems of indic a tors a pplied in river basins region based on initiatives of indicators in the world;

- To evaluate practices and environmental and susta ina bility management) related to municipal water resources based on selfassessment;

- To identify and involve the decision makers of the basin committees and other stakeholders in order to ensure their participation in the process of selection and development of the set of indicators based on Agenda 2030 (building the archetype);

- To apply the new methodological proposal of indicators systems developed in the previous stage, in order to evaluate the level of sustainability of the region and to visualize future scenarios.

\section{Methods}

\section{study area}

The study a rea of this research is delimited by the region of PCJ river basins, and has a n approximate area of $15,320 \mathrm{~km}^{2}$. Approximately $92 \%$ of this a rea a bout $14,040 \mathrm{~km}^{2}$ are in the State of São Paulo and the remaining $1,280 \mathrm{~km}^{2}$ belong to the State of Minas Gerais, Brazil, where the headwaters of the Jaguari, Camanducaia and Atibaia rivers are loc ated. This a rea is located between the meridians 460 and 49o west and the la titudes $22 \circ$ and $23.5 \circ$ so uth, presenting an approximate extension of $300 \mathrm{~km}$, in the east-west direction, and of $100 \mathrm{~km}$, in the north-so uth direction (AGENCIA DAS BACIAS PCJ , 2016).

The region of $\mathrm{PCJ}$ river basinscovers a reas of 76 munic ipalities, and 62 are headquartered in the region's drainage areas. Of these, 58 are in the State of São Paulo and four in Minas Gera is. With approxima tely five million inhabitants, this region is considered one of the most important in Brazil due to its economic development, which represents about 7\% of the National Gross Domestic Product (GDP). The munic ipalities of the State of São Paulo with headquarters in the region belong to Campinas, which also includes municipalities located in the Alto Mogi-Guaçu basin. In the PCJ basins there are five Govemment regions of Sã o Paulo's Sta te: Ca mpina s region, J undiaí region, Piracicaba region, Limeira region and Bragança Paulista region, which are intermediate levels of politic al-a d ministra tive management between the Administrative Region and munic ipalities. (PCJ , 2016).

The main justification for choosing the hydrographic basins of the Piracic aba, Capiva ri and J undiaí rivers for resea rch is the emerging need to communic ate (information system) the society and the main stakeholders about the levels of development and sustainability of these basins, which has great economic and strategic importance for the Sta te of São Paulo, Brazil, in order to evaluate the environmental, economic, social and institutional spheres seeking the understanding of the susta inable soc iety- environment relationship. 
System of Sustainability Indicators Applied...

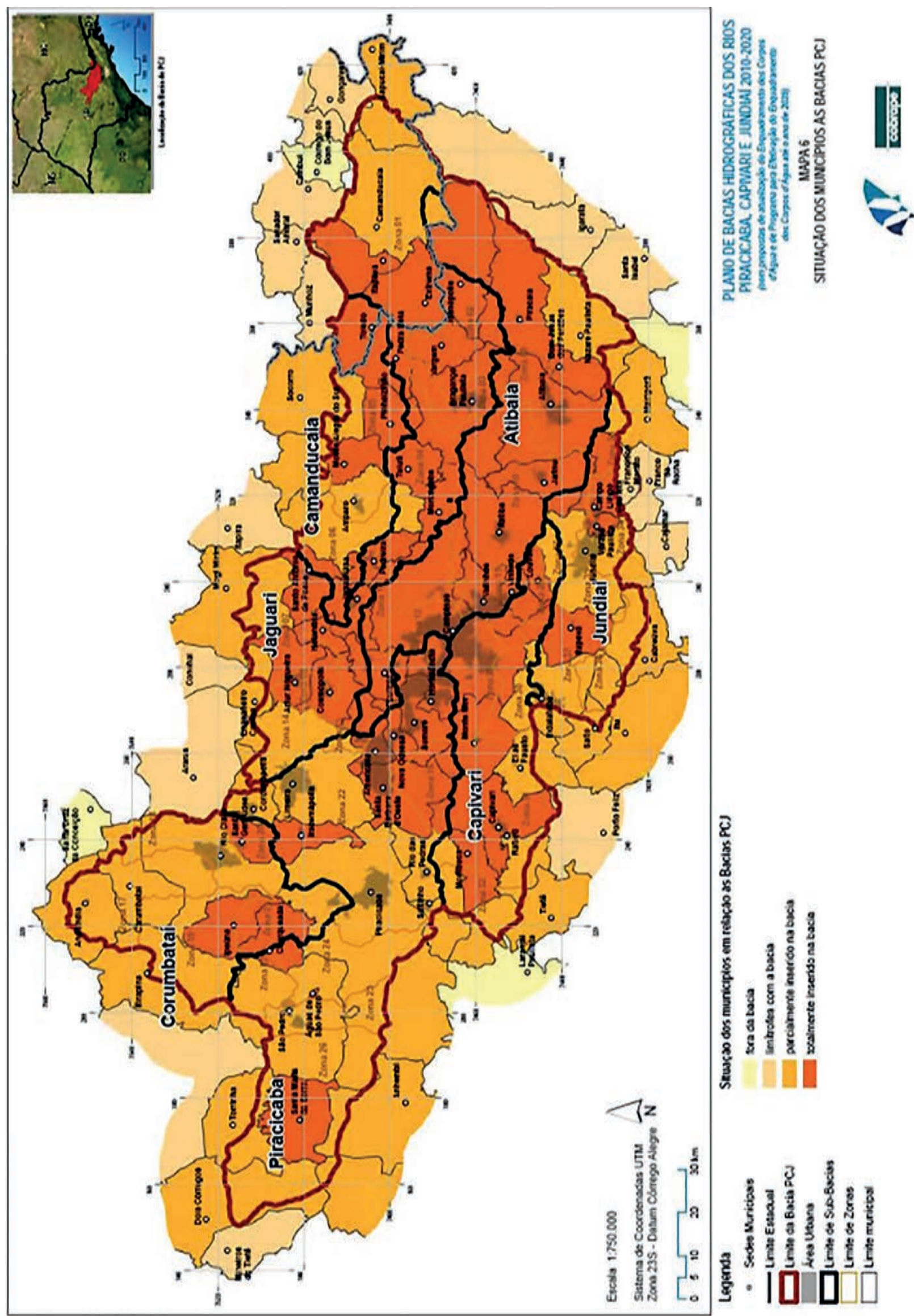

Figure 1 - Spatial location of the object of study. Source: Agência das Bacias PCJ, 2016. 


\section{Methodo 7 ogica 7 resources}

The research to be developed has qua ntita tive and qua lita tive cha rac teristics, characterized as a mixed method. The quantitative part will be based on a structured procedure for the collection of secondary data, sought in reference sources already used in the Basin Plan, and other sources that a re in line with the resea rch objectives. Already, in the qualita tive part will be used the semi-structured questionna ire instruments and individual and collective interviews, personally and electronically, with the participants chosen for the research, representing a focus group. In this case, the scope of potentially relevant info mation provided by the interviewee is restricted, where the interview guide has a directive function. Mixed methods allow better exploration and explanation of data and information, and are an opportunity to develop new methodological skills for research.

The triangulation method will be used to combine the results of qua ntitative and qualitative methods. In this case, the different methodologic al perspectives a re complemented for the a nalysis of a theme, this process being understood as the complementary compensation of the deficiencies and the obscure points of each isolated method. The basis of this view is that "qualita tive and qua ntitative methods must be seen as complementary rather than rival fields" (J ICK, 1983, p. 135). However, the various methods rema in a utonomous, continue to operate side by side, having as a meeting point the subject under study.

Figure 2 contains the methodological summary in a simplified way.

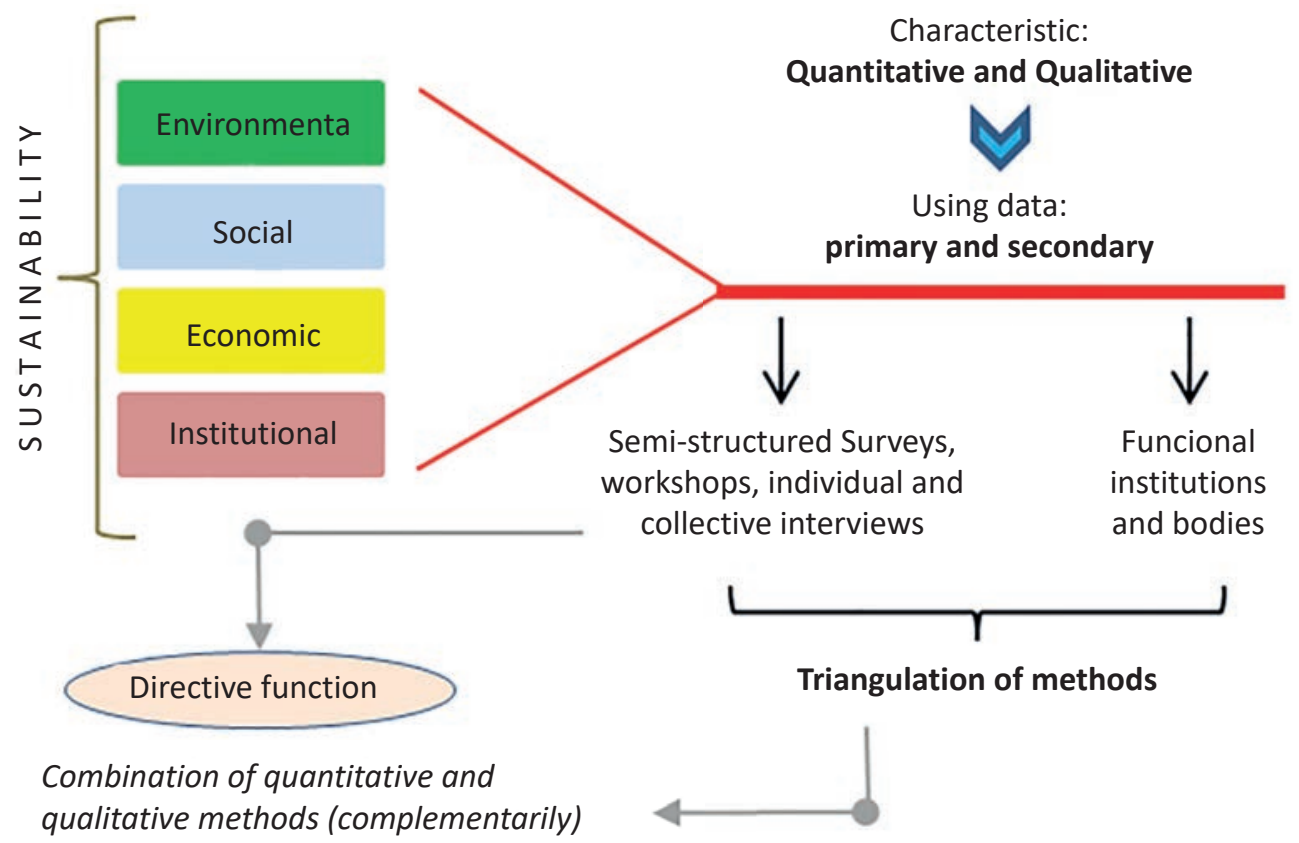

Figure 2 - Methodological summary of study. Source: Prepared by the authors. 


\section{Preliminary results}

So far we can offer some preliminary results of this research. We generate the profile of river basin initiatives in the world that use indic a tors in their experiences. These findings genera te the general profile:

- Regionalarea;
- Using pure indicators approach;

- Based on environmental scope; (it limits the evaluation of sustaina bility, and does not reflect the interactions between environment and society).

These findings may be better perceived in Figure 3.

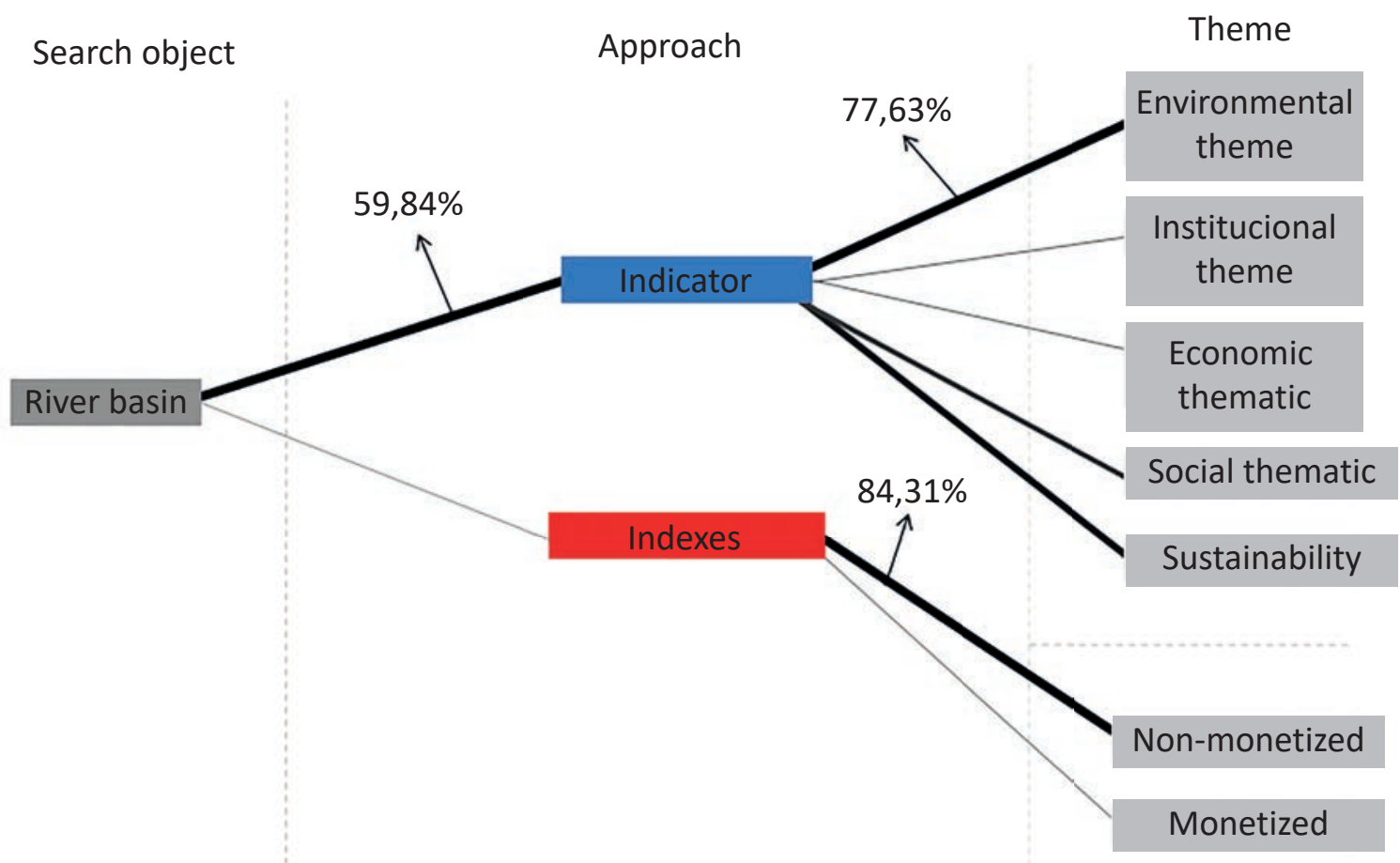

Figure 3 - Profile of river basin initiatives in the world using indicators. Source: Prepared by the authors.

In indexes the scope does not have a centra lity in the environmental dimension, using different dimensions (ecological, social, economic, and institutional). Here the non-monetized was greater than the monetary valuation.So far we have the following findings regarding field research:
- 76 munic ipa lities a re involved in this research;

- $42 \%$ were concluded so far being $70 \%$ face-to-face visits;

- $58 \%$ of them had a high level of response (75\% - 100\%).

Figure 4 presents these preliminary field work findings. 
Municipalities covered so far $\longrightarrow 42 \% \longrightarrow 70 \%$ face-to-face visits

\begin{tabular}{|c|c|}
\hline $\begin{array}{c}\text { Distribution by size of municipality in study } \\
\text { area }\end{array}$ & Proportion \\
\hline up to 100 thousandinhabitants & $74 \%$ \\
\hline 100 thousand - 500 thousandinhabitants & $25 \%$ \\
\hline above 500 thousand inhabitants & $1 \%$ \\
\hline
\end{tabular}

\begin{tabular}{|c|c|}
\hline Responses by municipality size so far & Proportion \\
\hline up to 100 thousandinhabitants & $47 \%$ \\
\hline 100 thousand - 500 thousand inhabitants & $35 \%$ \\
\hline above 500 thousand inhabitants & $100 \%$ \\
\hline
\end{tabular}

Figure 4 - Preliminary results of fieldwork.

According to the literature of the topic studied, the level of response is considered acceptable for a nalysis of the results. However, we are still looking to improve these numbers to provide a more robust result.

There is inc rea sing recognition of one's own institutional limitations in dea ling with complex problems at all spatial scales. The findings of this research point to the need for institutional innovations a nd their forma lization and emancipation before public management, with the creation and performance of participatory procedures prescribed in specific laws, such as in the area of water resources, where the participation of multi-sta keholders through the Watershed Committees represents a signific ant breakthrough for good govemance. It is necessary to consolidate the artic ulation between institutions at the municipal level so that the dimensions of susta inability a re treated in a fair and proactive way, so that progress towards regional sustainable development is possible. The diffic ulty in this research so far is to access and streamline a link with the va rious stakeholders and to build interfaces with inter-sectora I relationships to stimula te the flow of information in these networks.

Many challenges have been found for the construction of evaluation systems with ind ic a to rs like: geogra phic al or spatial delimita tion; temporal disc ontinuity; validation; type of aggregation; lack of information; subjectivity of the concept of susta ina bility; a ccess to data; decision support/policy advisor; methodological consensus; integration of information; mea sura bility; complexity; qua lity of data; potential use; medium and long-term approach - targets; legal congruence; partic ipatory ap proach; relevance; credibility; legitima cy; tra nspa rency; technical knowledge; effective communication; compara tive a na lysis; op era tio na liza tion; selection; monitoring; self-evaluation; scope definition. 


\section{References}

AGENCIA DAS BACIAS PCJ- PIRACICABA, CAPIVARI E JUNDIAÍ. Informações das bacias PCJ. Avaiable from: http://www.agenciapcj.org.br/novo/informacoesdas-bacias>. Access: july, 2016.

ALSHUWAIKHAT, H.M., ABUBAKAR, I.R., AINA, Y.A., ADENLE, Y.A. and UMAIR, M., 2017. The Development of a GIS-Based Model for Campus Environmental Sustainability Assessment. Sustainability, vol. 9, no. 439, pp.1-23.

BATALHÃO, A.C.S. and TEIXEIRA, D., 2017. Indicators Approaches in Municipal Sustainability. Saarbrücken: Novas Edições Acadêmicas.

HARMANCIUGLU, N. B., BARBAROS, F. and CENTIKAYA, C. P., 2013. Sustainability Issues in Water Management. Water Resources Management, vol. 27, pp. $1867-$ 1891.
JICK, T., 1983. Mixing Qualitative and Quantitative Methods: Triangulation in Action. IN: MAANEN, J. V. (ed.), Qualitative Methodology. London: SAGE. pp. 135-148.

MICKWITZ, P., MELANEN, M., ROSENSTROM, U. and SEPPALA, J., 2006. Regional eco-efficiency indicators - a participatory approach. Journal of Cleaner Production, vol. 14, no. 18, pp. 1603-1611.

RAMOS, T.B., 2009. Development of regional sustainability indicators and the role of academia in this process: the Portuguese Practice. Journal of Cleaner Production, vol. 17, pp. 1101-1115.

SANTOS, R.F., 2004. Planejamento Ambiental: teoria e prática. São Paulo: Oficina de Textos.

WU, H. and LEONG, C., 2016. A composite framework of river sustainability: integration across time, space and interests in the Yellow River and Ganges River. Water Policy vol. 18, pp. 138-152. 



\title{
The Management of Water Resources as a Factor of Urban Resilience
}

\author{
Corrêa, T.H.P. ${ }^{1}$, Teixeira, B.A.N. ${ }^{1}$
}

'Pós Graduação da Universidade Federal de São Carlos (UFSCar)

Corresponding author: tha isprado@hotmail.com, bemardo@ufscar.br

\section{Abstract}

The urban centers represent a dense and complex system of interconnected servic es and as such face a growing number of aspects leading to disaster risk. In this way, urb a n resilience emerges as a city's a bility to resist, absorb, a dapt and recover from exposure to threats, producing effects in a timely and effic ient manner, which includes preserving and restoring its structures and functions. For the development of the project it is intended to work the city in the context of urban waters, through a case study of three munic ipa lities in which criteria such as size (small, medium or la rge), water a va ila bility (high, medium or low) and vocation of the municipality (tourism, agribusiness, industry, among others) will be carried out a methodologic al adaptation that will present a n evaluation tool for the applic a tion of resilience thinking, a iming at increasing the understanding of water resources and their vulnera bility in cities. Water safety is a key determinant of city growth, so the development of methodologies that assess urban systems will help planners to address water issues and develop a legal framework to regulate, guide, and promote the practice of resilience water resources. Therefore, as a result, the resea rch a ims to provide technic al inputs for decision-making on resilient development through integrated water resources management to generate wa ter sec urity at the loc al level and river basin committees.

Keywords: resilient cities, waters in resilient cities, urban waters, water resources, management of water resources, susta ina bility. 


\section{Introduction}

Resilience is a concept often used in many fields, specific ally ecology, economics, and engineering. According to Djordjevic et al. (2011) there a re several definitions for the same concept. Resilience is determined by the degree to which the social system is able to organize itself to increase its learning capacity with past $d$ isasters, protection of a better future and for the improvement of risk reduction measures.

In 2013 the Rockefeller Foundation la unched a network called 100 Resilient $\mathrm{C}$ ities. This is a $\mathrm{n}$ initia tive that is dedic ated, through funds to share experiences and peer-to-peer knowledge to help cities to adapt to the shocks and pressures of today's world and turn them into opportunities for growth (THE ROC KEFELLER FO UNDATION, 2016). Nowadays a mong the participants of the network there a re cities like Barcelona, Milan, Pa ris, London, Boston Lisbon, Chicago, Singapore and Buenos Aires. In Brazil, there a re Porto Alegre, Rio de J aneiro and Salvador as partic ipants as well.

\section{Objective}

The general aim of the research is to evaluate the role of integrated water resources management in the urban environment as a resilience factor. After understanding the problem, we want to identify and evaluate methodological options. We hope to present results such as the discussion about the applic ation of methodology studied to support the selection of a methodology with better applic ability for the study object. We also hope to identify stakeholders and their roles in the development stages of the methodology; to discuss the need to invest in water sec urity for the resilient development of the cities; to develop and disc uss strategies for water resilience of those cities; to disc uss the results with members of river basin committees and potential users, and to disc uss the potential applic ability of the study to other river basins.

\section{Method}

The method and the work plan that will be used in the research are presented, and can be visualized in the flow chart of Figure 1.

\section{Construction of the Conceptual Base}

Cities and urban a reas represent a dense and complex system of interc onnected services. As such, they face a growing number of aspects that lead to the risk of disaster. Strategies and public policies can be developed to meet each aspect as part of a global vision to build cities of all sizes and more resilient and livable profiles. (UNITED NATIONS OFFICE FOR DISASTER RISK REDUCTION, 2012).

Resilience at the munic ipal level recognizes the urban a rea as a dynamic and complex system that must continuously adapt to various challenges in an integrated and holistic way (UNITED NATIONS 2015), so through the integrated and predictive planning of water resources it is possible to build a resilience to better manage water resourc es and, consequently, benefit va rious sec tors of so c iety. 


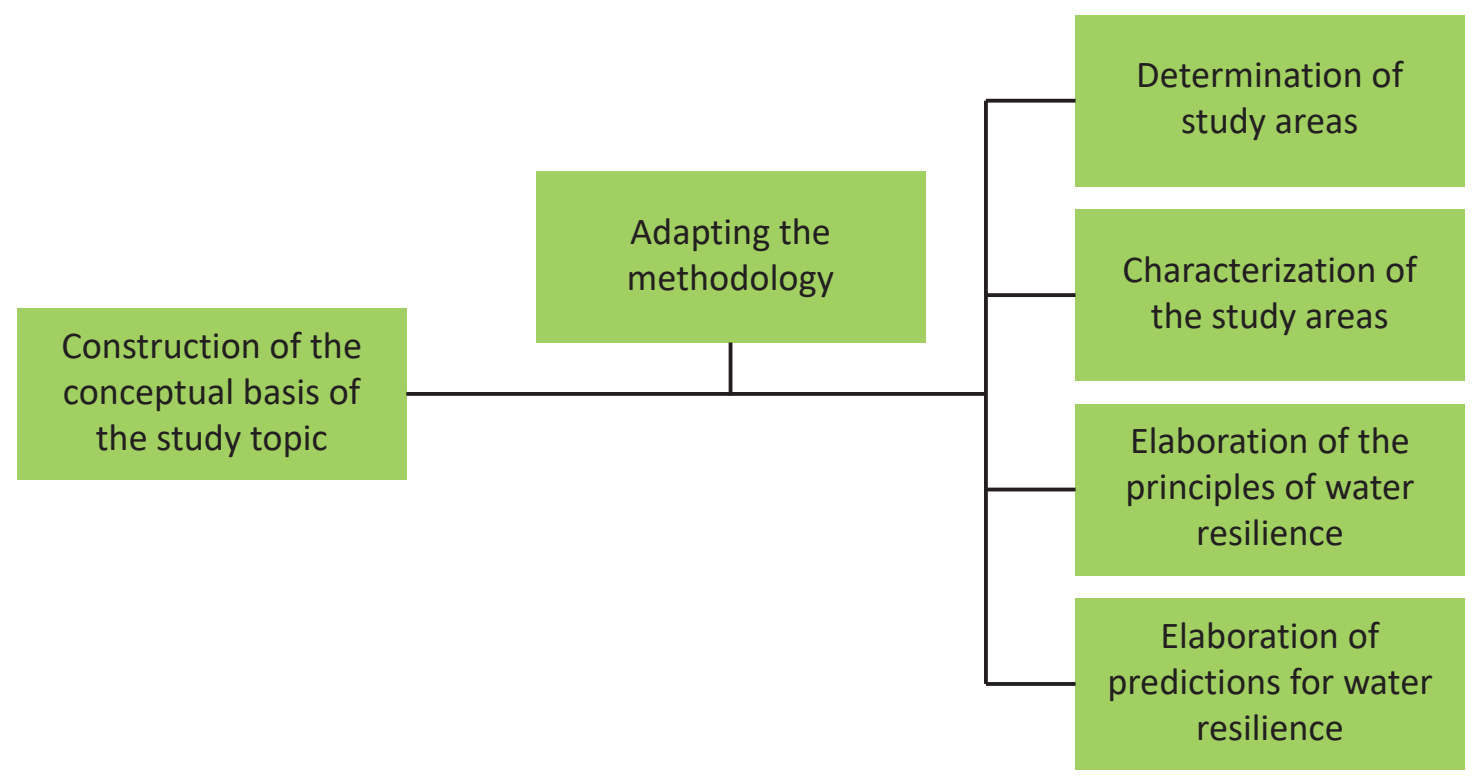

Figure 1-Schematic representation of the work plan.

In order to evaluate the hypotheses, a descriptive research of an exploratory na ture will be camied out, in order to deepen the bibliographical review with articles published in international and national joumals, books, theses, dissertations and also in the legislation regarding urban planning, resilience and water resources. Experiences will also be raised in other cities that a re applying the concept of resilience.

The methodological line to be followed contemplates the aspect of exploratory and descriptive character, aiming to understand the context of the topic addressed.

\section{Determination of study areas}

For the development of the project, it is intended to work the city in the urban context by carrying out a case study in three munic ipalities in which criteria such as size (small, medium or large), a va ila bility of water (high, medium or low) and vocation of the munic ipality (to urism, a gribusiness, industry, a mong others). For the study, the cities of São Carlos and Brotas in the State of Sã o Paulo and Porto Alegre in Rio Grande do Sul will be used. Two munic ipa lities, São Carlos-SP and Brotas-SP, are included in the Tietê-J acaré Basin and the municipa lity of Porto Alegre-RS is inserted in the Lagoa da Guaíba Hydrographic Basin. The cities mentioned have the following charac teristic s:

São Carlos-SP: medium size, with high water a va ilability with vocation for industry;

Brotas-SP: small and with high water a va ila bility and voc a tion for to urism;

Porto Alegre-RS: large size, high water a va ila bility and with vocation for ind ustry and agriculture. 
In the case of Porto Alegre, there is more interest in study because the city is a partner of the Rockefeller Foundation and has joined the campaign of Resilient Cities of the United Nations (UN), The city a Irea dy has a resilient stra tegy developed.

It is worth mentioning that the munic ipa lities and the criteria to determine the cities can be modified, since they will depend on the application of the methodology.

\section{Adaptation of urban resilience construction methodology}

A city can be understood as the place that concentrates the offer of cultural, religious, infra structure or consumption services bringing together the most diverse streams of human activities. According to Benevolo (2006), this overlapping of func tions is due to the different a c hievements of its inhabitants over time, which are juxtaposed in the urban environment to a dapt the struc ture to diverse needsand interests. Therefore, a city has elements that differ from one a nother, making it necessary for the methodology to be used to be applied according to its specific ities.

For the adaptation of the methodology will be made an evaluation of the characteristic s of the methods used in the conceptual basis and their a pplic ability in the Brazilian munic ipalities that will be studied in the project.

The aim is to adapt the methodology of the Resilience Alliance for the construction of urban resilience through water resources. The Resilience Alliance is a research network of scientists and practitioners from different $d$ isc iplines working to develop and apply the concepts of resilience. Resea rchers develop a "Resilience Assessment" methodology as "an altemative way of thinking and practicing natural resource management" (RESILIENCE ALIANCE, 2007a). There a re several formats for conduc ting a resilience assessment, as presented in two versions of a manual for professiona ls (RESILIENCE ALLIANCE, 2007a; RESILIENCE ALLIANCE, 2007a), a ma nual for scientists (RESILIENCE ALIANCE, 2007b) and publications such as Walker et al . (2009) a nd Stric klandMunro et al. (2010). This literature is quite consistent in a general approach: a group with specialized knowledge will define the bounda ries of the system, its components and key issues; will characterize real and potential system dynamics (thresholds and altema tive sta tes), and uses this understanding to decide "where and how to intervene in the system in order to increa se resilience" (RESILIENCE ALLIANCE, 2007a).

The idea is that the methodological adaptation presents a n evaluation tool for the application of resilience thinking , aiming to increase understanding of water reso urces and their vulnera bility in cities. 


\section{1 - DEFINING THE SYSTEM \\ Key issue: System boundaries \\ (space and time) and focal scale}

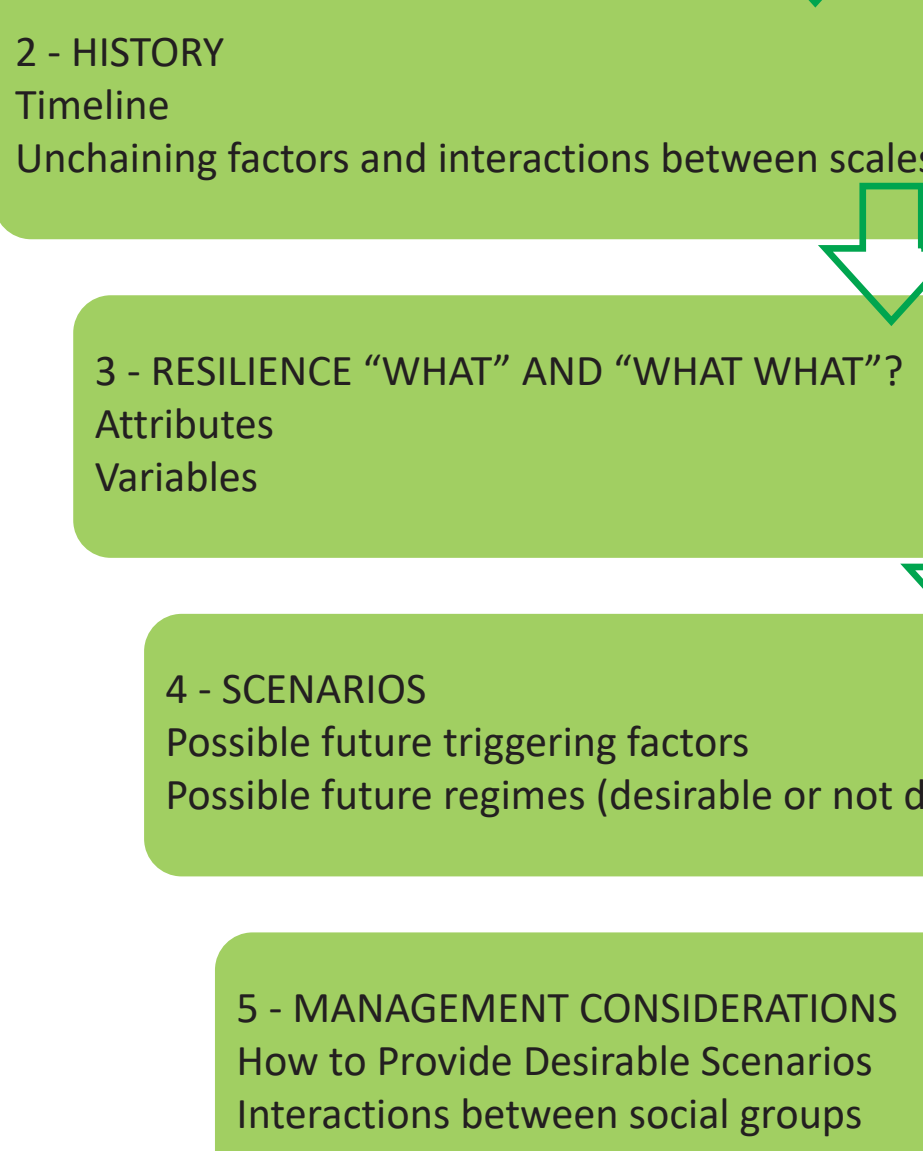

Figure 2 - Resilience evaluation methodology developed by Buschbacher et al. (2016). Adapted from Buschbacher et al. (2016).

\section{Characterization of study areas.}

In order to better understand the functioning of the hydrologic al system of the municipalities and to define the fields and strategies of action of the water resilience, the following investigations will be made:

- Classification of the vocation of the munic ipality (tourism, industry, agribusiness, a mong others);

- Diagnose the areas of greatest water vulnerability of the munic ipa lity; 
- Evaluate the water connection, analyzing how the rivers and streams are flowing and their environmental quality (level of vita lity);

- Historical survey of the transformations that occurred in water bodies, such as rivers, streams, lakes and ponds, flooded and floodable areas, including in areas where there was occupation process;

- To compare the occupancy times and the transformations that occurred to verify the interventions that may have altered the flows and the natural processes of the waters over time, with changes in the land uses and the consequent waterproofing;

- Map existing bodies and water flows, visible or subterranean drainage channels and the sanitation system, rainfall and prevailing precipitation flows, waterways and places where they accumulate and the history of wetlands and their vulnerability to precipitation volumes;

- To quantify the infiltrated, detained and retained waters and their contribution to avoid floods and to supply the aquifers and underground sheets;

- Evaluate the percentage of impermeable soil in the urban area, measuring the amount of water that flows superficially.

\section{Application of the modified methodology}

After the completion of the previous processes, the methodology will be applied adapted in the munic ipalities under study, in order to test the hypothesis through concrete situations. To do so, the data collected in the study a reas will be inserted in the methodology and future scenarios will be proposed to be considered in the evaluation of the instrument elaborated.

\section{Expected Results}

Water is a key factor for the sectors of economic growth and contributes to employment, job creation and gross domestic product (GDP), it is at the heart of the development goals of most sectors, including health, energy, a griculture, environment and social protection. However, most countries a re far from achieving water security and the triggering of c lima te change will further jeopardize their prospects.

Water safety is a key determinant of city growth, so the development of methodologies that a ssess urban systems will help planners to a ddress water issues and develop a legal framework to regulate, guide, and promote the practice of resilience water resources.

Therefore, after understanding the problem, identifying and evaluating methodological options, the following results a re expected:

- Discussion on the applied methodology of application, to substantiate the selection of a methodology with better applicability for the object of study in question;

Id entify stakeholders and their roles in the development of the methodology;

- Discuss the need to invest in water security for the resilient development of munic ipa lities;

- Develop and discuss strategies for action of water resilience in munic ipa lities; 
- Disc uss results with members of niver basin committees and potential users;

- Discussion on the potential applicability of the study to other niver basins.

\section{Discussion}

Problems and limitations in urban water management are among the main causes of ec onomic losses in cities. Water safety is a determinant by city growth, so the development of methodologies that evalua te urban systems will help planners to address water issues and develop a legal framework to regulate, guide and promote the practices of water resilience.

\section{References}

BENEVOLO, L., 2006. The city and the architect. Lisbon: Editions 70.

BUSCHBACHER, R. et al., 2016. Resilience Assessment as a tool for understanding the Amazon frontier as a social-ecological system. Sustainability in Debate, Brasília. vol. 7, no. 2, p. 36-52. Available in: <http:// periodicos.unb.br/index.php/sust/article/view/15134>. Access: Oct. 2016.

UNITED NATIONS, 2012. United Nations Office for Disaster Risk Reduction. How to Build More Resilient Cities- A Guide for Local Public Managers. Translation to: How to Make Cities More Resilient- A Handbook for Mayors and Local Government Leaders. Geneva, Switzerland: United Nations Office for Disaster Risk Reduction- UN / ISDR.

UNITED NATIONS ORGANIZATION IN BRAZIL, 2013. ONU: more than $70 \%$ of the world's population will live in cities by 2050. 15 April. 2013. Available in: <https://nacoesunidas.org/onu-mais-de-70-dapopulacao-mundial-vivera-em-cidades-ate-2050/>. Access: 30 Sep.2016.
In this way, it is possible from the study of wa ter reso urc es to establish new methodologies and processes for cities to become more resilient and, consequently, to develop new strategies and tools.

They could be used to a nalyze the intemal dyna mic s of urban ec osystems as well and thus reassess the planning of the city to make the best decision of making the use of the water resources when it faces the challenges imposed by the rapid urbanization.

\section{Acknowledgement}

The Federa I University of Sã o CarlosUFSC ar. The Coordination of Improvement of Higher Level Personnel - CAPES.

RESILIENCE ALLIANCE, 2007a. Assessing Resilience in Social-Ecological Systems: A Workbook for Practitioners. Version 1.1.

RESILIENCE ALLIANCE, 2007b. Assessing Resilience in Social-Ecological Systems: A Workbook for Scientists. Version 1.1. Available in: <http://library.uniteddiversity. coop/Transition_Relocalisation_Resilience/resilience_ workbook_for_scientists.pd>. Access: Sep. 2016.

STRICKLAND-MUNRO, J.K.; ALLISON, H.E.; MOORE, S.A., 2010. Using resilience concepts to investigate the impacts of protected area tourism on communities. Annals of Tourism Research. vol. 37, no. 2, pp. 499519. Available in: <http://www.sciencedirect.com/ science/article/pii/S0160738309001479>. Access: Oct. 2016.

WALKER, B.H. et al., 2009. Resilience, adaptability, and transformability in the Goulburn-Broken Catchment. Australia. Ecology and Society, vol. 14, no. 1. Available in: <https://dlc.dlib.indiana.edu/dlc/bitstream/ handle/10535/2601/http__www.ecologyandsociety. org_vol14_iss1_art12_.pdf?sequence=1>. Access: Oct. 2016. 



\section{Assessment of an in situ Real Time UV/VIS Based Spectrometry System for Chemical 0xygen Demand Measurement in a Wastewater Anaerobic Treatment Reactor}

Hernández. O.A.D. ${ }^{1}$ Lisboa, A.M. ${ }^{2}$ Cantã o, M.P. ${ }^{3}$, Possetti, G.R.C. ${ }^{2}$, Aisse, M.M. ${ }^{3}$

IInd ustrial Engineer (Universidad Nacional Experimental del Tachira - UNET, Venezuela), Master in Environmental Management and Audits (Universidad Europea Miguel de Cervantes - UEMC, Spain), Tea cher in the Universidad Nacional Experimental del Tachira - UNET, Doctorate in Water Resources and Environmental Engineering (Federal University of Pa ra ná - UFPR, Brazil).

${ }^{2}$ Research and Development Advisory, Companhia de Saneamento do Paraná (SANEPAR, Brazil).

${ }^{3} \mathrm{G}$ raduate Program in Water Resources and Environmental Engineering (PPGERHA, Federal University of Pa raná - UFPR, Bra zil).

*Correspondence author: oranduherl@gmail.com

\section{Abstract}

Analysis of physic al and chemic al parameters is more and more important for operation chec king and performance control in wastewater treatment plants (WWTP). Recently developed UV/VIS spectrometry based sensors are being used for measurement of parameters like chemical oxygen demand (COD). The a im of this work is to report results ofreal time in situ COD measurementusing a spectrophotometric system in a wa stewa ter trea tment plant with upflowa na ero bic sludg eblanket (UASB). The studies 
focused a medium size WWTP (wastewater average flow a round $319 \mathrm{~L} / \mathrm{s}$ ) located in Paraná State (Brazil), and used several statistical tools, like as rela tive error, boxplot charts, statistical dispersion, Student's t-test (significance level $a=0.05$ ) and bilateral test, to compare measurement system results with la boratorial a nalyses. The results indic ate that sensor monitoring can be effective for the UASB affluent, as the probe mea surement results a nd la bora to rial a na lyses of COD showed no sta tistic al signific a nt difference for three different calibration scenarios. Linear local calibration showed the best performance in the assessed WWTP, with mean error being $4.32 \%$, standard deviation $\sigma=2.76 \%$ and determination coefficient $\mathrm{R}^{2}=0.7667$. For the UASB reactor effluent the behavior has not shown the expected adherence: only the offset calibration, among four assessed methods, showed no signific ant difference, with mean error being $27.53 \%$, standard deviation $\sigma=24.11 \%$ and determination coefficient $\mathrm{R}^{2}=0.1246$. COD removal efficiency in the WTP was between $56 \%$ and $60 \%$.

Keywords: UV/VIS Spec tro photometry, COD, UASB, Probe, Sa nitation System.

\section{Introduction}

In the wastewater treatment plants of Brazil, and of Paraná Sta te in particular, the upflow anaerobic sludge blanket (UASB) treatment method is prevailing, due to its low energy consumption, reduced a rea requirement and higher operational simplic ity. Besides, UASB reactors have low sludge production and reduced implantation cost (CHERNIC HARO et al., 1999).

Sampling and analysis a re more and more important for treatment plants operation assessment, since the highquality data of present systems allow plant monitoring. Traditional approach is based on punctual short runs for sampling and later laboratory a nalyses, which use to be leng thy, demand expensive and/ortoxic reagents and produce residues needing la ter trea tment (VANRO LLEG HEM, LEE, 2003; BRITO et al.,2014).
Usually assessed parameters, like as tempera ture, $\mathrm{pH}$ and conductivity a mong others, can be continuously monitored. In the last few years some papers reported the monitoring of total organic carbon (TOC), tota I suspended solids (TSS) and chemical oxygen demand (COD) using spectrometric techniques (BRITO et al., 2014).

The chemical oxygen demand is a global parameter very used as ind ic ator of oxygen content in design and control of UASB ana erobic trea tment systems (CHERNICHARO et al., 2015). Aisse et al. (2002) obtained COD = $151 \pm 64 \mathrm{mg} / \mathrm{L}$ as a typical value for the effluent of domestic wastewater treated in UASB reactor. Considering a value of $453 \pm 147$ $\mathrm{mg} / \mathrm{L}$ for COD in the affluent the a uthors determined a removal efficiency of $69 \%$. The volumetric organic load (VOL) can be assumed to be $1.80 \mathrm{~kg}(\mathrm{COD}) \cdot \mathrm{m}^{-3} \cdot \mathrm{day}^{-1}$, for a hydraulic retention time of 8 hours. 
The full UV spectrum has been used for the TOC, COD and biochemical oxygen demand $\left(\mathrm{BOD}_{5}\right)$ estimation in wa stewater (THOMAS et al., 1997). The spectrometry in the ultra violet and visible ranges (UV/ VIS) a llows to obta in releva nt information (VAN DEL BROEKE et al., 2006; BRITO et al., 2014). It is a fast and easy to implement technique, used for wastewater quality assessment (THOMAS et al., 2005). The used wavelength varies from 200 to $800 \mathrm{~nm}$, and it is possible to relate the radiation absorbance features (absorption wavelength ranges) with the compounds that account for COD values.

In the measurement process it is very important to consider the sample peculia rities (matrix effect) and assessment of the error, which can be reduced with previous calibration and with control of local sampling variables, such as flow fluctuation, coarse solids and equipment cleansing. A good monitoring depends on true results. Van der Broke et al. (2006) affirm that online spectra a cquisition has been implemented in most WWTP. One can a dmit that mea surement instruments must deal with additional c hallenges, due to water quality matrix va riability and to facility related operation and safety issues (BRITO et al., 2014). There are few works in Brazil that support the installation of in situ COD real time probes in UASB reactors based WWTP.

In this respect, the objective of this work is to report the results of using a spectrophotometric measurement system for real time in situ COD determination in a wastewater trea tment plant with up flow anaerobic sludge blanket reactor.

\section{Metodology}

\section{Location of Study}

This study took place in a medium size WWTP with a verage flow of $319 \mathrm{~L} / \mathrm{s}$, located in Curitiba, PR. The wastewater pretreatment occurs in a system composed of $20 \mathrm{~mm}$ manual screen, $3 \mathrm{~mm}$ mechanic al sc reen, grit removal system, Pa rshall flume and the biological treatment is done in six UASB reactors, each one with rated c apacity of 70 L/s.Post treatment of a naerobic effluent post-trea tment could take place in aerated facultative ponds.

\section{Wastewater COD Concentration Meter (Probe)}

The COD measurement system, Carbolyser model supplied by S::can (shown in Figure 1) is composed of a probe and a control unit. The system can determine concentrations between 100 and 3,250 mg(COD)/L using UV/VIS spectrophotometry. The probe measures the difference between optical intensity emitted by a lamp inside the measuring window and the optical intensity that reaches the detector, after crossing the waste water flow. The probe is $0.6 \mathrm{~m}$ in length and $44 \mathrm{~mm}$ in diameter, operates in a wavelength range between 200 and $750 \mathrm{~nm}$ and uses a xenon la mp. 


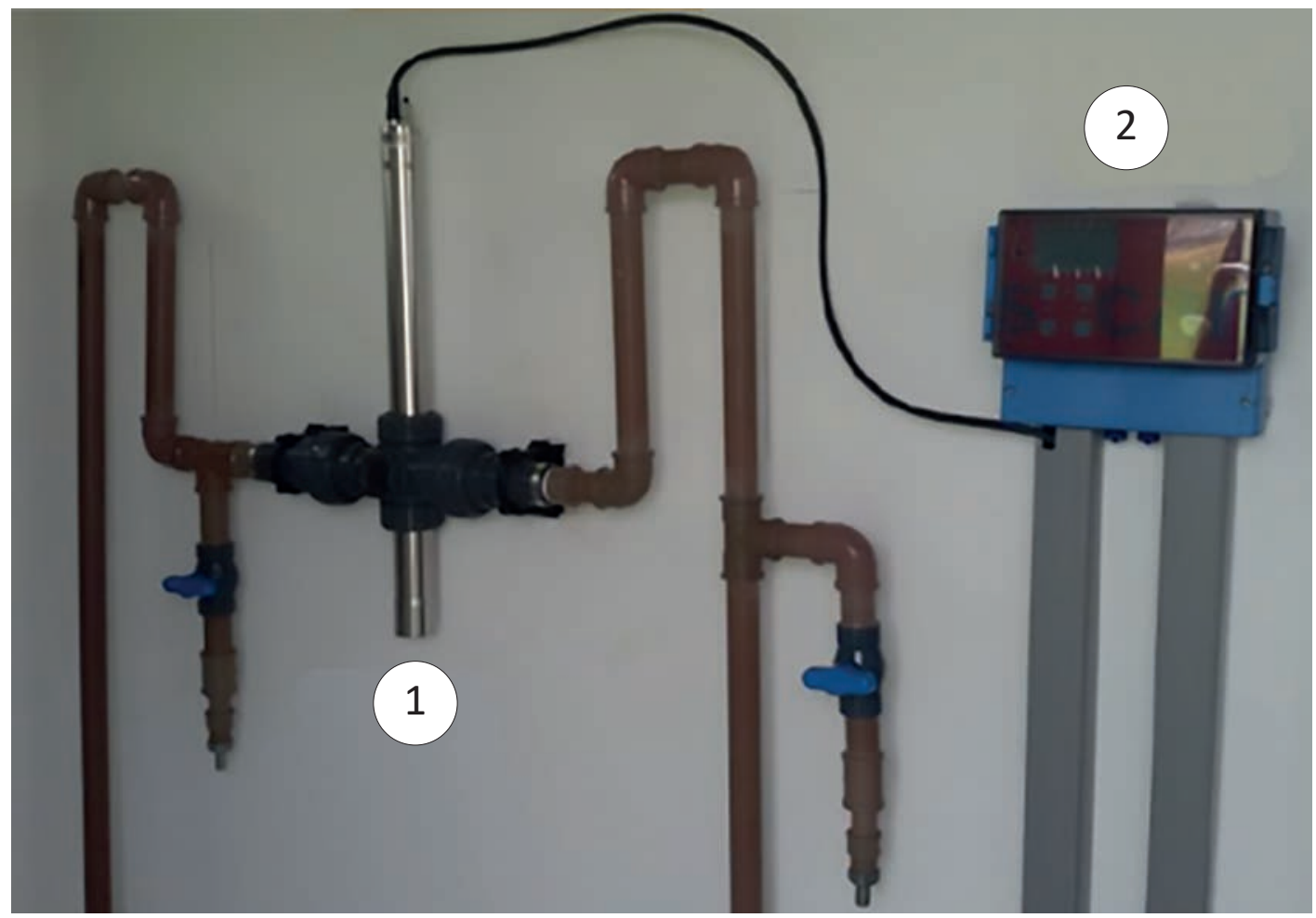

Figure 1-COD probe installation layout. Notes: (1) Carbolyser probe (spectrophotometer); (2) Equipment control display.

The insta lla tion of the instrument in the WTP allowed the assessment of a ffluent to and effluent from the UASB reactor, using an automated pumping system for altema te sampling of affluent and effluent flows.

The COD measurement system has a compressed a ir self-cleaning system with maximum pressure of 5 bar; manual cleaning is also allowed. The cleaning procedure, developed for the removal of solid deposits from the measurement hollow, includes the use of lukewarm water, pure ethanol and brushes provided by the manufacturer. The frequency of the manualcleaning wasincreased from biweekly to two times a week after day 14 reading.
Calibration Methods and Comparison with Laboratory Analyses

Besides the real-time mea surements, collec ted wastewater samples were analyzed in laboratory, through procedures preconized in the APHA Standard Methods (APHA, 2012).At laboratory the samples were transferred to a digestion flask at 150 ㄷ for 2 hours. COD was determined by colorimetric method based on absorbance measurement at $620 \mathrm{~nm}$ in a workbench spectrophotometer DR6000 (Hach Ind ustries) and previous calibration curve. Total 25 affluent and 29 effluent sa mples were collected in different days, between 9:00 and 11:00 am and during summer and a utumn of 2016. 
The calibration of the COD measurement system installed in the WTP was done so that the samples covered the historic va riation of wastewater concentration values. Three scenarios were outlined for affluent COD readings: 1 ) global calibration (from factory), 2) local offset calibration (for both field and laboratory measurements, used to fit the global calibration to present situation, shifting the position but not the inclination of global calibration curve), and 3) local linear calibration (from two field samples and two laboratory results, global calibration inclination and alignment change). For the effluent COD recording 4 scenarios were proposed: 1) global calibration (from factory), 2) local offset calibration, 3) local linearcalibration, and 4) new calibration curve supplied by the manufacturer.

Results were a nalyzed with statistic al tools such as percentage mean error, boxplot charts, sc atter plots, Student's t-test, for two samples with presumed equivalent variances and significance level $a=0.05$, and bilateral test, to compare results obta ined from measurement system at WTP with la boratory a nalyses.

\section{Results and Discussion}

Figure 2 shows the rela tive error between values registered by mea surement system installed in WTP and values obtained in the laboratory analyses, for wastewa ter affluent samples. Mean relative error va lues is $64.7 \%$ $\pm 64.0 \%$ for global ca lib ration (rea ding days \#1 to \#11), $38.3 \pm 40.5 \%$ for offset calibration (\#11 to \#20) and $4.3 \pm 2.8 \%$ for local linearcalibration (\#21 to \#25). The improved probe performance from day \#16 can be attributed to the increased cleaning frequency (from biweekly to two times a week) from day \#14.

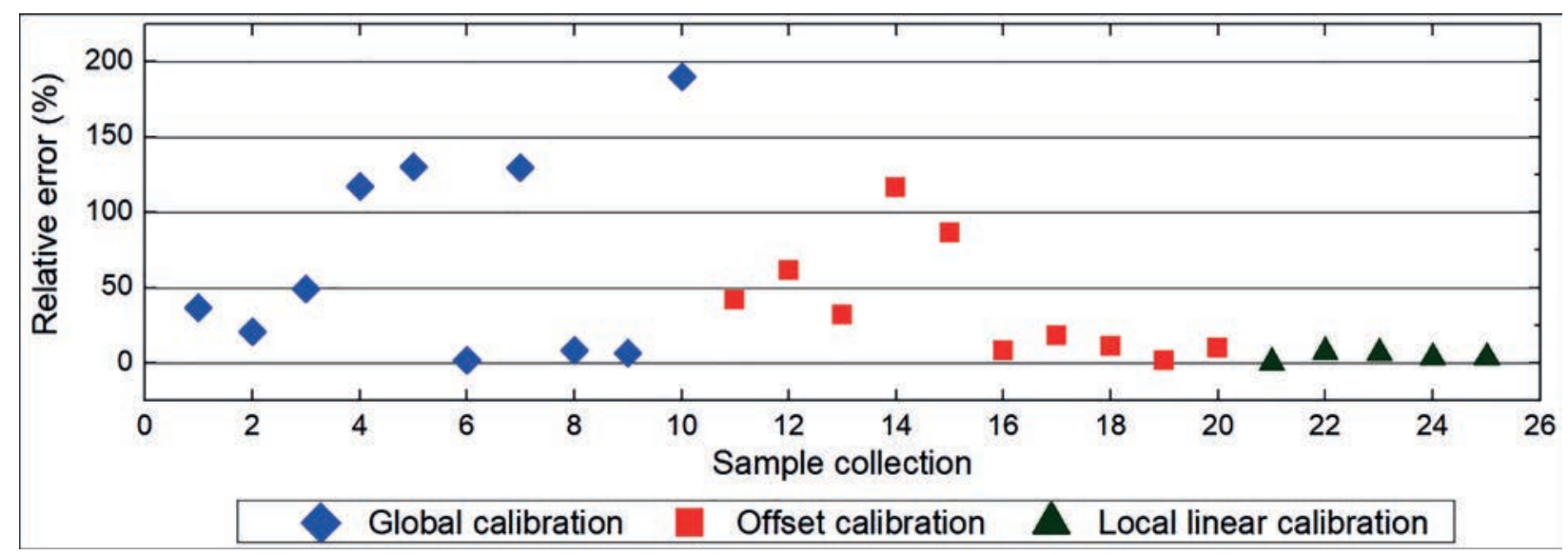

Figure 2 - Relative error scatter plot for the affluent in the calibration modes: global, offset and local linear. 
Figure 3 shows the COD boxplot charts for the wastewater affluent, measured by the probe and in the laboratory. For global calibration (Figure $3 a$ ) the a verage probe measured COD is $708 \pm 252 \mathrm{mg} / \mathrm{L}$ and $486 \pm 250 \mathrm{mg} / \mathrm{L}$ at the laboratory; in the case of offset calibration (Figure $3 b$ ) probe average COD is $705 \pm 152 \mathrm{mg} / \mathrm{L}$ and laboratory a verage, $562 \pm 190 \mathrm{mg} / \mathrm{L}$; for the local linear calibration (Figure $3 c)$, probe average COD is much closer to laboratory a verage: $650 \pm 52 \mathrm{mg} / \mathrm{L}$ (probe) and $651 \pm 73 \mathrm{mg} / \mathrm{L}$ (laboratory). The linear calibration has shown the best results among the three scenarios.

The applic a tion of Student's t-test in all the three calibration scenarios has not shown signific ant differences. Nevertheless, it is clearfrom Figures 2 and $3 c$ that linear calibration is the best one in comparison with global (manufacturer) and offset calibrations, based on its lowest rela tive error, equal to $4.3 \%$, and on the lowest difference between probe and laboratory averages.

Figure 4 shows the scatter plots of affluent COD results obtained with laboratory a na lyses versus mea surements obta ined with the probe at WTP, assessed with the three different calibration scenarios. The following determination coefficient $\left(R^{2}\right)$ values were found: 0,6178 for global calibration (Figure 4a), 0,4612 for local offset calibration (Figure 4b) and 0,7667 for local linear calibration. Aga in, the loc al linear calibration scenario is the more adequate to the studied situation.

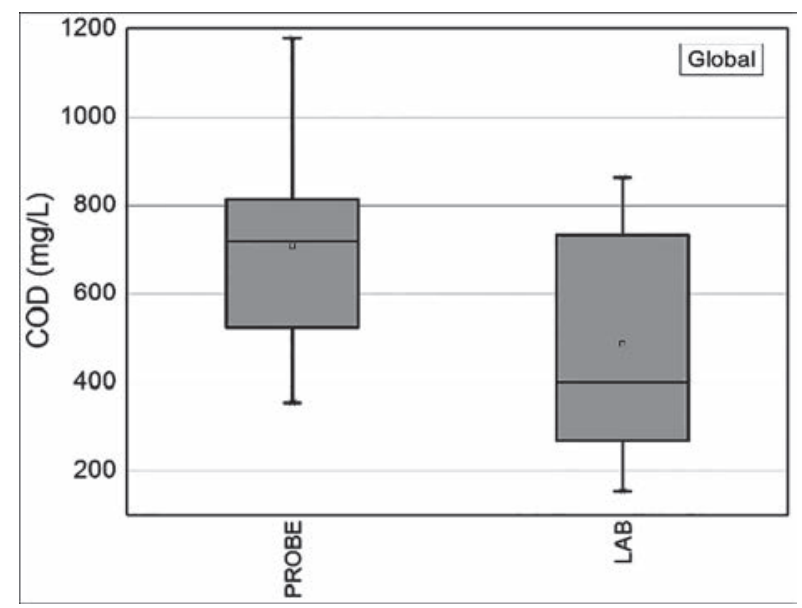

(a)

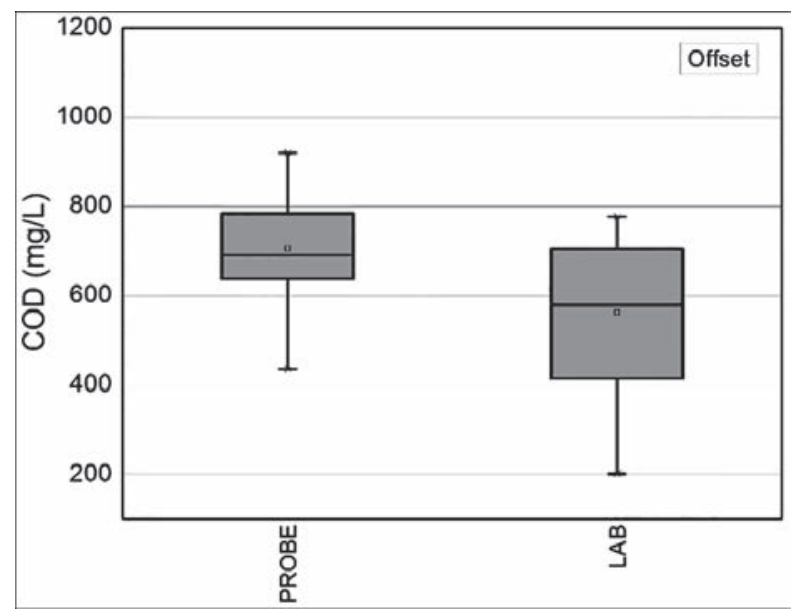

(b)

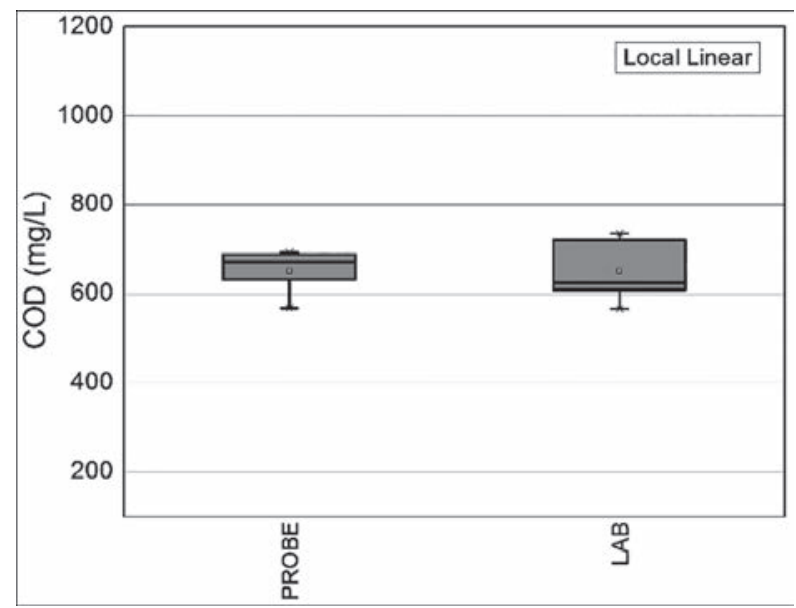

(c)

Figure 3 - Boxplot charts for the affluent: (a) global calibration; (b) local offset calibration; (c) linear local calibration. 


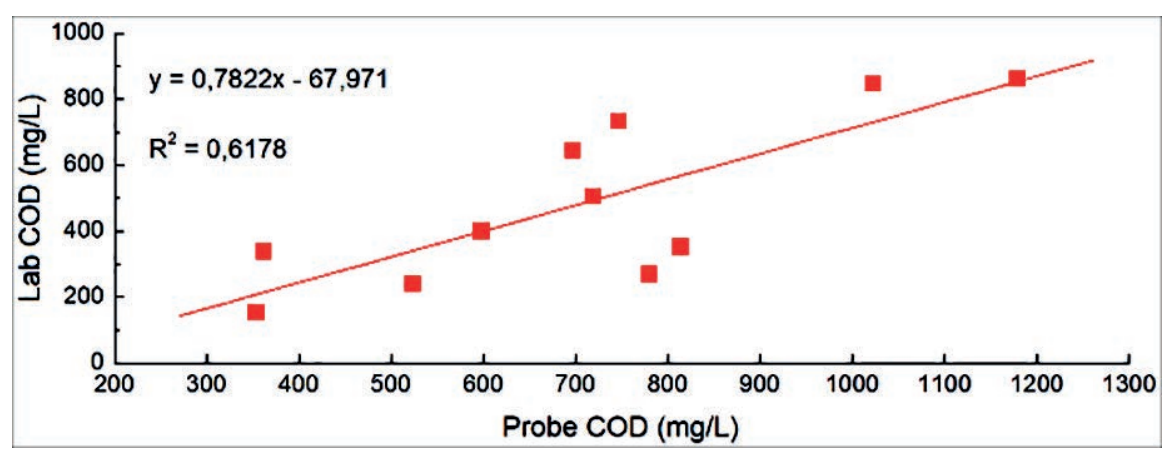

(a)

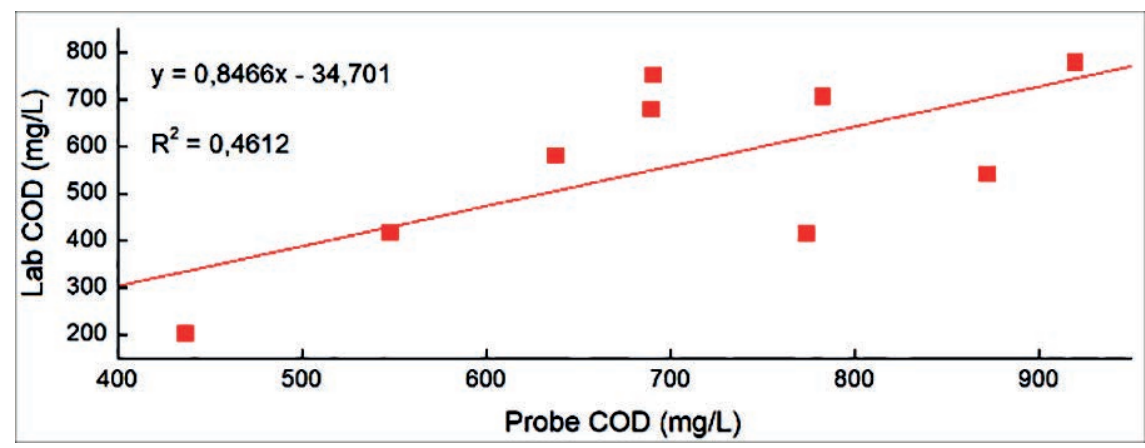

(b)

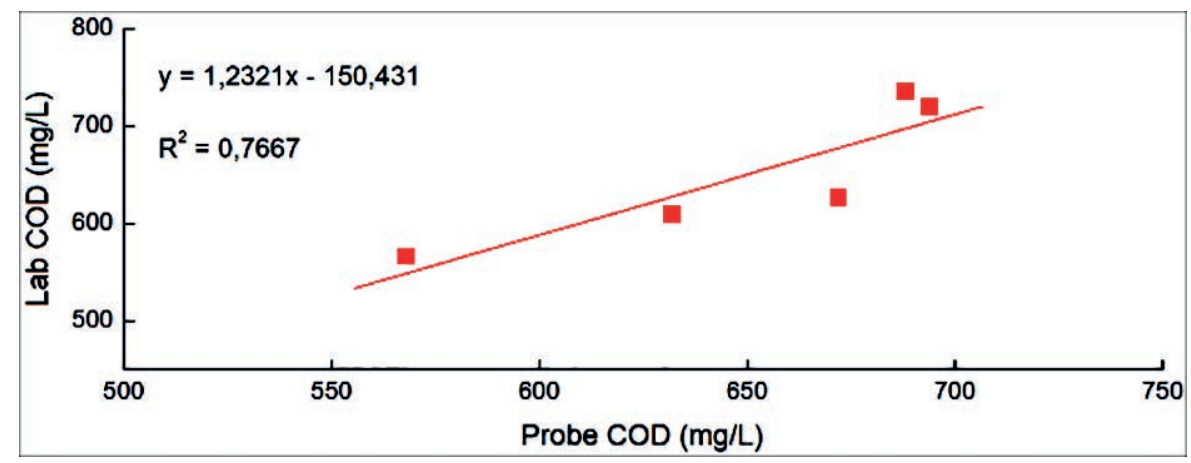

(c)

Figure 4 - Affluent CODlaboratory vs. probe dispersion scatter plots: (a) global calibration; (b) local offset calibration; (c) local linear calibration.

The relative error between the probe and the laboratory values for the effluent are shown in Figure 5.

Between readings \#1 and \#9 (manufacturer global calibration) the observed a verage error is $51.66 \% \pm 35.60$; for the measurement days from \#10 to \#19 (local offset calibration) the found error is $27.53 \pm 24,11 \%$; for the sa mples \#20 to \#24 the recalibrated probe (local linear calibration) has shown a $n$ a verage error of $10.09 \pm 1.95 \%$. 


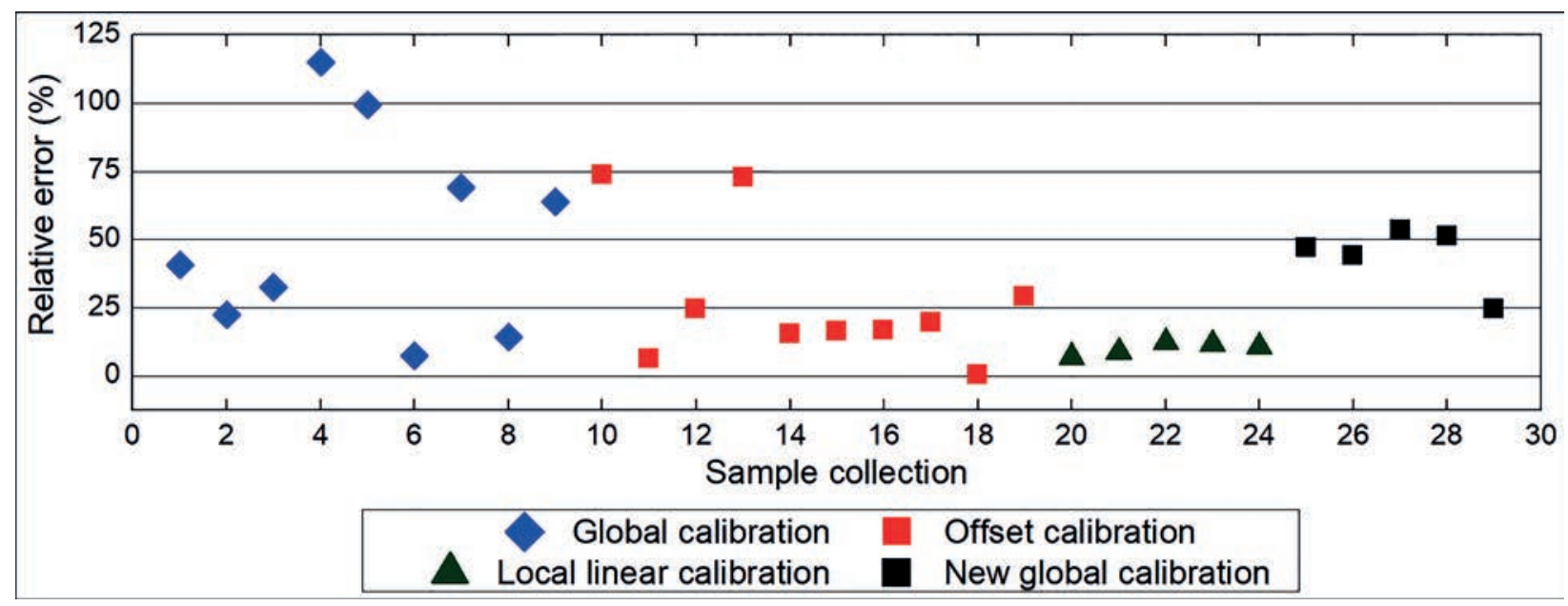

Figure 5 - Effluent COD relative error dispersion scatter plot for: (a) global calibration; (b) local offset calibration; (c) local linear calibration; (d) new global calibration.

As for the affluent samples, the increased cleaning frequency improved the probe performance for effluent samples from collection day \#14. Besides the previous three calibration scenarios, a new global calibration was supplied by the probe manufacturer, with a verage relative error of $44.14 \pm 10.25 \%$. The effluent COD values can be seen in Figure 6 , for the four different calibration conditions.

The probe has not shown the expected adherent behavior for the wastewater effluent. Forglobal calibration (Figure 6a) measurements with the probe showed average COD of $319 \pm 73 \mathrm{mg} / \mathrm{L}$ and laboratory results of $225 \pm 68 \mathrm{mg} / \mathrm{L}$. For local offset calibration (Figure $6 \mathrm{~b}$ ) the results were $277 \pm 60 \mathrm{mg} / \mathrm{L}$ with the probe and $241 \pm 53 \mathrm{mg} /$ Lat the laboratory. Local linearcalibration results (Figure $6 c$ ) were
$242 \pm 4 \mathrm{mg} / \mathrm{L}$ with the probe and $270 \pm 9$ $\mathrm{mg} / \mathrm{L}$ at the la boratory. Finally, a verage COD results were $114 \pm 43 \mathrm{mg} / \mathrm{L}$ with the probe and $204 \pm 74 \mathrm{mg} / \mathrm{L}$ at the laboratory for the new global calibration.

The application of Student's t-test ind ic a ted that only offset calibration has not showed signific ant difference between probe and laboratory mea surements, rejecting the other three conditions.

Figure 7 shows the determination coeffic ient $R^{2}$ for the effluent in the four studied calibration scenarios. The $R^{2}$ equals 0,3845 for global calibration (Figure 7a), 0,1246 for loca I offset c a libration (Figure 7b), 0,5566 for local linear c a libration (Figure 7c) and 0,7927 for the new global calibration (Figure 7d). 


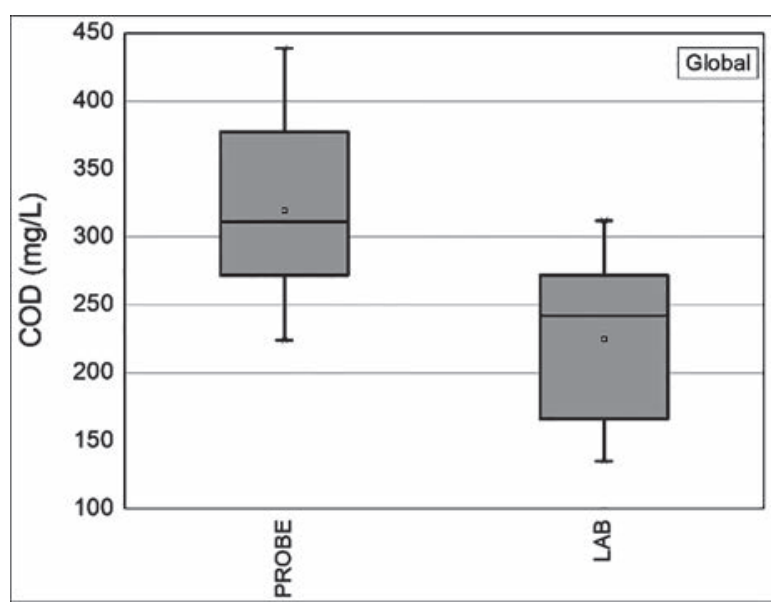

(a)

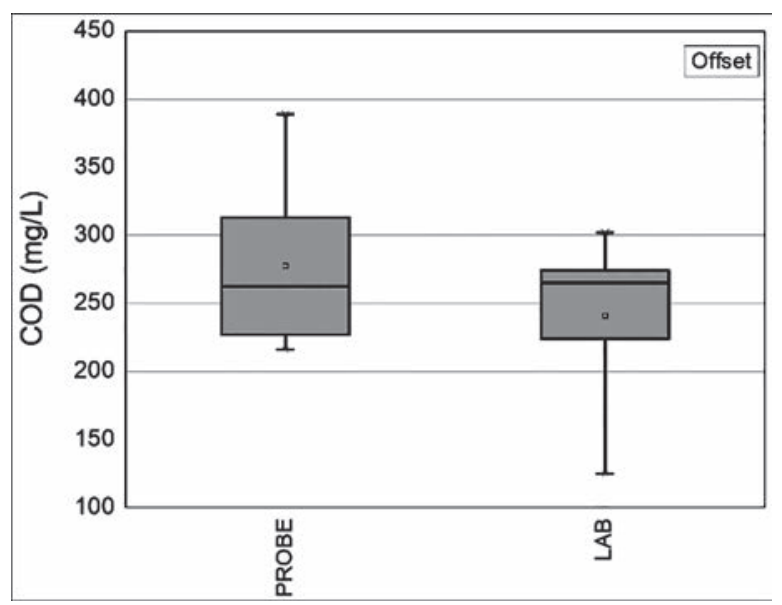

(b)

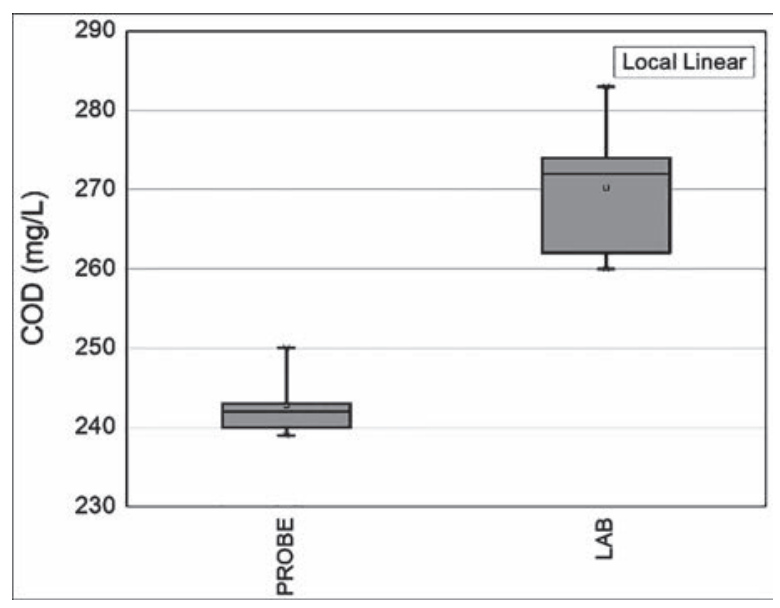

(c)

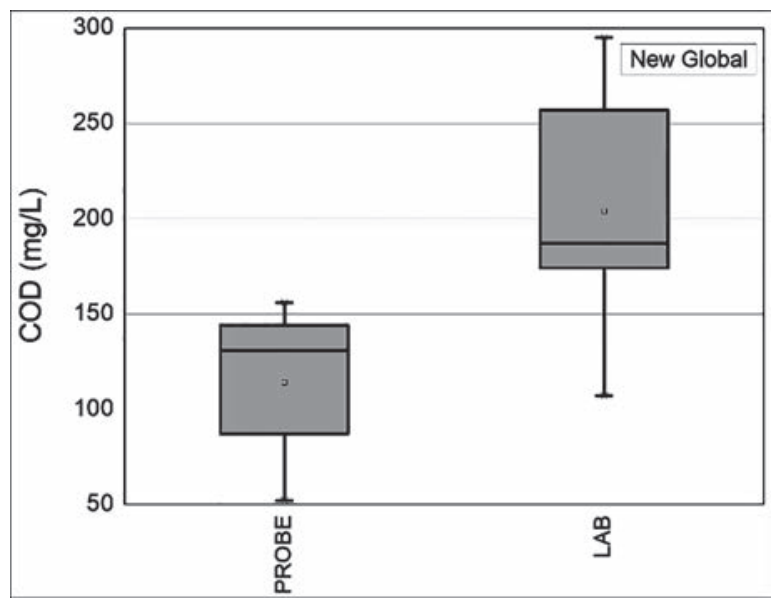

(d)

Figure 6 - Effluent boxplot charts for the different calibration scenarios: (a) global calibration; (b) local offset calibration; (c) local linear calibration; (d) new global calibration.

\section{Other Comments}

One possible explanation for the difference between probe and laboratory mea surements is that the spectrophotometer detec ts only the organic matter fraction absorbing in the UV/VIS range, e.g. organic acids and carbon hydrates. The laboratory analysis detects sulfide, chloride and Fe(II) ions by dichromate oxidation. If the probe spectrophotometer has not the ability to detect ion species, field measurements should give lower COD values. According Figures 4 and 7 , this is the case only for the wastewater effluent and only forlocal linear and new global calibrations.

The probe has the important ability to mea sure, besides COD, total suspended solids. J oint c a libration can allow fitting the parameters of the initia lly built intrinsic software model (Gruber et al., 2006). This can improve the supplier's global calibration, which has not shown reliable values for the effluent. 


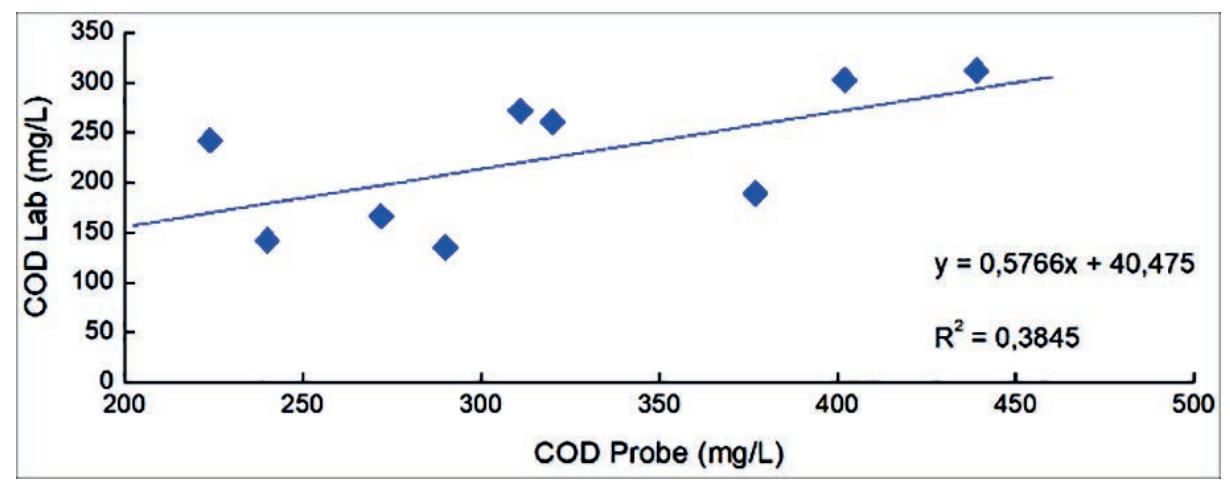

(a)

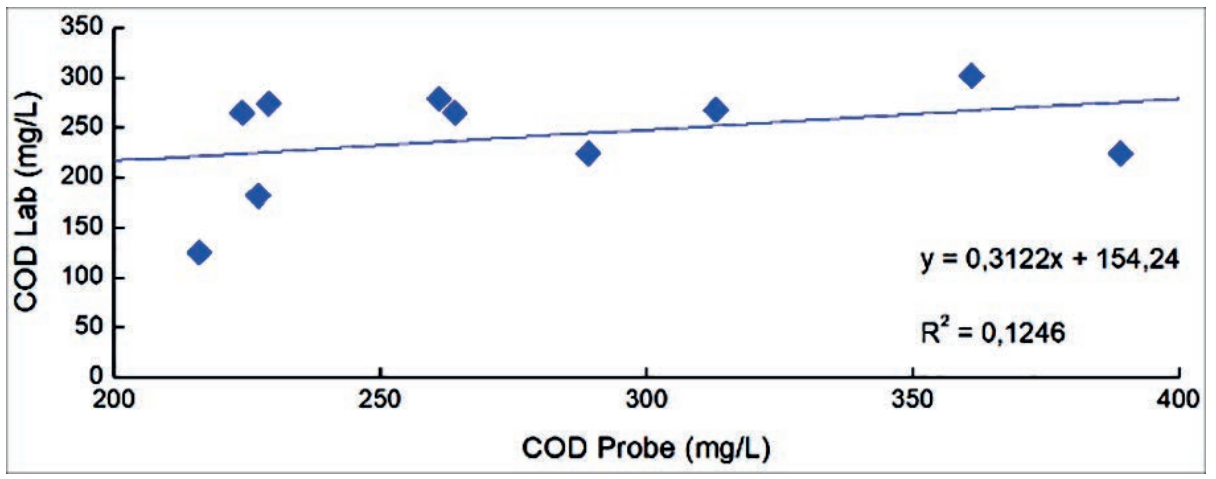

(b)

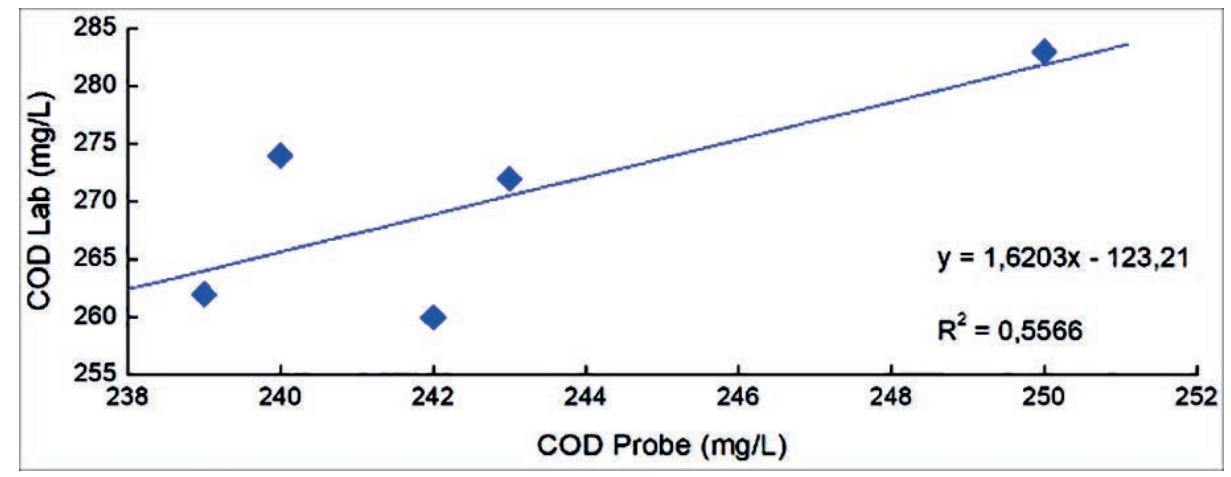

(c)

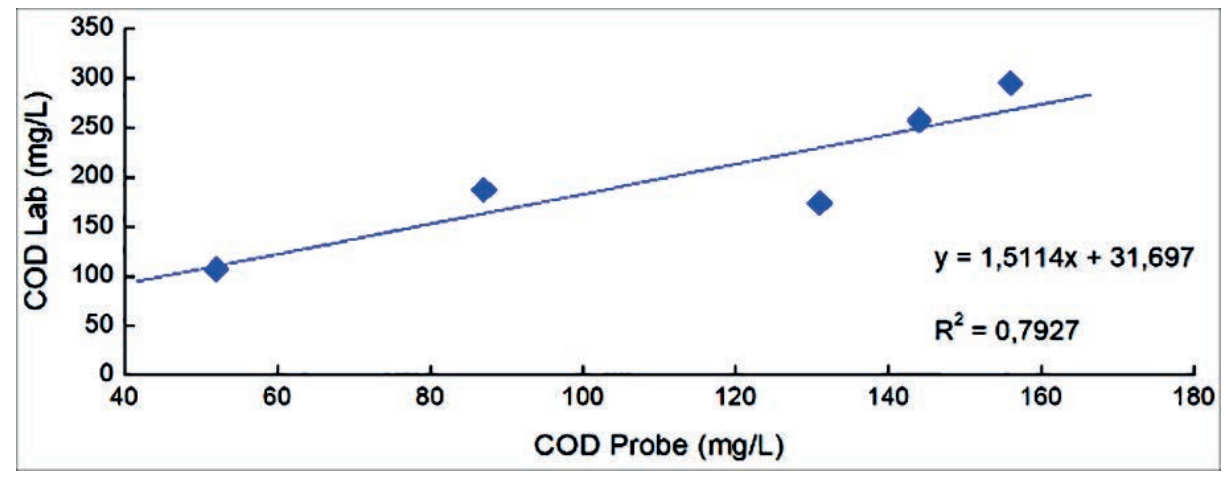

(d)

Figure 7 - Dispersion scatter plots for calibration modes: (a) global calibration, (b) local offset calibration, (c) local linear calibration, (d) new global calibration. 
It is worth mentioning that this study is the first attempt to use spectrophotometry for a ssessment of COD in wastewater trea tment UASB reactors, a successful tec hnology for urban drainage. The local linearcalibration is the best adapted configuration for affluent wastewater monitoring and it also has shown the sma ller rela tive errors for effluent sa mples.

\section{Operationa 1 Aspects}

It is mandatory to avoid a ir bubbles, optic al window hindrance and other measurement interfering phenomena (VANRO LLEG HEM et a I., 2003). The se phenomena were recurrent in this study, including obstruction and clogging of the pipeline connecting the effluent/affluent boxes to the probe site. The frequency of retention valves cleaning and pumps ma intenance was increased to mitigate these problems. Feeding pump flow speeds lowerthan $3 \mathrm{~m} / \mathrm{s}$ ensured the measurement quality. Weekly ma intenance and cleaning of submersible pumps kept the optical window free of impurities, which could encumber the measurement. Additionally, distilled water and detergent together with manual brushing completed the cleaning process.

Air cleaning systems are an important requirement spec trophoto meter relia bility. If cleaning a ir systems a re not able to remove the grime deposited on the measurement window COD values tend to be increased (drift) (GRUBER et al., 2005). According to Langengraber et al. (2004), Gruber et al. (2005). Air clea ning systems should prevent film formation and growth, but in this study case it was not enough to eliminate the film formed at the window, even using the maximum allowed pressure (5 mbar). The UASB wastewater characteristic s could be the reason for this phenomenon, and additional studies are needed.

Cleaning issues were a specific variable in this study and can be related to calibration modes. Manufacturerglobal calibration is based on standard algorithms developed for typic al a pplic a tions, but wastewater quality matrix can vary with location and wastewater origin. Local c a libration can reflect this va ria bility and produce better estimation results (LANGERG RABER et al., 2004; BRITO et al., 2014). The present study ind ic a tes the importance of local calibration adapted to the brazilian wastewater matrix.

\section{Assessment of Removal Efficiency for UASB reactor}

Table 1 summarizes the UASB reactors performance, with lowest relative error being the choice criterion of collection days. For the chosen collection days, the relative error between probe and laboratory measurements were $10 \%$ for the affluent and $13 \%$ for the effluent. 
Table 1 - UASB reactor performance assessment ${ }^{(1)}$.

\begin{tabular}{lccccccc}
\hline Parameter & Unit & $\begin{array}{c}\text { COD } \\
\text { affluent }^{(2)}\end{array}$ & $\begin{array}{c}\text { COD } \\
\text { effluent }^{(3)}\end{array}$ & $\begin{array}{c}\text { TSS } \\
\text { affluent }^{-}\end{array}$ & $\begin{array}{c}\text { TSS } \\
\text { effluent }\end{array}$ & $\begin{array}{c}\text { COD } \\
\text { efficiency }\end{array}$ & $\begin{array}{c}\text { TSS } \\
\text { efficiency }\end{array}$ \\
\hline Probe & $\mathrm{mg} / \mathrm{L}$ & 682 & 271 & - & - & $60 \%$ & - \\
\hline Laboratory & $\mathrm{mg} / \mathrm{L}$ & 613 & 267 & 196 & 82 & $56 \%$ & $58 \%$ \\
\hline
\end{tabular}

Notes: (1) observation period from January to May 2016, collection schedule from 9 to $11 \mathrm{am}$; (2) values for collection day \#16 on; (3) values for collection days \#14 and \#24.

One can notice that both measurement tec hniques provided similar COD removal effic iency values ( $56 \%$ and $60 \%$ ). For the entire assessment period ( $\mathrm{J}$ anuary to May 2016) COD removal measured at the laboratory was $56.76 \%$, with average of $541 \mathrm{mg} / \mathrm{L}$ at reactor entry and 234 at the exit. These effic iency values a re simila $r$ to the lower limit COD reported by Aisse et al. (2002) and Chemicharo et al. (2015), a uthors who compilated the performance of anaerobic treatment plants in large scale, with focus on brazilian plants. The assessed WTP operates with hydraulic retention timesclose by the rated value.

\section{Conclusions}

The scope of this study was to assess the real time in situ utilization of a spectrophotometric measurement system with COD probein UASB reactor entry and exit of a wastewater treatment plant located in the Paraná State.

Results allow to conclude that monitoring can be effective for the UASB affluent. COD values obta ined with spectrophotometric probe and laboratory colorimetric a nalysis have shown no sta tistically significant difference for three different calibration scenarios. Linear local ca libration is the most a dequate to the WTP wastewater conditions, with average relative error equal to $4.32 \%$, standard deviation of $2.76 \%$ and 0.7667 for the determination coeffic ient.

The probe has not shown the expected adherence for the UASB reactor effluent. Global calibration has not shown any reliable value for the effleuent and only the local offset calibration, a mong four calibration scenarios, has shown no significant difference (average relative error of $27.53 \%$, standard deviation of $24.11 \%$ and determination coeffic ient of $0.1246)$. COD removal efficiency values were between $56 \%$ and $60 \%$, close by the lower limit reported in the literature for brazilian wastewa ter trea tment plants.

Therefore, the applic ation of spec trophoto meter tec hniques consists of an advancement to the real time in situ monitoring of brazilian wastewa ter trea tment plants. Even then the spectrophotometric 
probes could not be considered as wa stewa ter quality indic ators, they allow real time monitoring wastewater trea tment plants. However, it is necessary to first define the best practices to obtain more reliable results. The development of cleaning procedures is a n example of a better practice adequate for the UASB reactor WTP.

\section{Recommendations}

The following recommendations will base future works on the use of spectro photometer techniques in wastewater trea tment plants:

- Improvement of the COD measurement for the effluent with probe operation changes, since the results were not conclusive in this case.

\section{REFERENCES}

AISSE, M.M., LOBATO, M.B., JÜRGENSEN, D. and ALÉM SOBRINHO, P., 2002. Tratamento de Efluentes de Reatores Anaeróbios. (Treatment of Anaerobic Effluents with Discharge of Aerobic Sludge to the UASB Reactor). In: VII Taller e Simposio Latino Americano sobre Digestion Anaerobia. Merida, Mexico.

APHA - AWWA - WEF, 2012. Standard Methods for the Examination of Water and Wastewater.

BRITO R.S., PINHEIRO, H., FERREIRA F., MATOS, J.S. and LOURENÇO, N., 2014. In situ UV-Vis spectroscopy to estimate COD and TSS in wastewater drainage systems. Urban Water Journal, vol. 11.

CHERNICHARO, C., VAN HAANDEL A., AISSE, M.M. and CAVALCANTI, P., 1999. Reatores anaeróbios de manta de lodo. In: CAMPOS, J. R. (coord). PROSAB. Rio de Janeiro ABES, p.55-198.

CHERNICHARO, C.A.L., VAN LIER J., NOYOLA, A.R., and BRESSANI T., 2015. Anaerobic sewage treatment: state of the art, constraintsand challenges. Environ Sci Biotechnol, vol. 14, pp. 649-679.
- Building of global calibration curves adequate for the Brazilian wastewater condition, for example, UASB reactors effluent.

- Assessment of behavior and correlations for other variables, also measured with the probe, such as filtered COD and total suspended solids (for UASB affluent and effluent), and the different posttrea tment configurations used for the anaereobic affluent.

\section{Acknowledgements}

The a uthors are grateful to the BrazilGermany Project on Biogas (PROBIOGÁS) for the research funding, and to SANEPAR, UFPR and UFMG for the manifested support. To OEA for the granted studentship during the doctorate course.

GRUBER, G., BERTRAND-KRAJEWSKI, J.L., DE BÉNÉDITTIS, J., HOCHEDLINGER, M. and LETTL, W., 2006. Practical aspects, experiences and strategies by using UV/VIS sensors for long-term sewer monitoring. Water Practice \& Technology, vol. 1.

GRUBER, G., WINKLER, S. and PRESSL, A., 2005. Continuous monitoring in sewer networks- an approach for quantification of pollution loads from CSOs into surface water bodies. Water Science \& Technology. IWA, vol. 52, no. 12, pp. 215-223.

LANGERGRABER, G., WEINGARTENER, A. and FLEISCHMANN, N., 2004. Time- resolved delta spectrometry. A method to define alarm parameters from spectral data. Water Science \& Technology. vol. 50, no. 11, pp. 13-20.

OJEDA, C. B. and SÁNCHEZ, F., 2009. Process analytical chemistry. Applications of ultraviolet/ visible spectrometry in environmental analysis. An overview. Applied Spectroscopy Reviews, vol. 44, pp. 245-265 
RIEGER, L., LANGERGRABER, G. and SIEGRIST, H., 2006. Uncertainties of spectral in situ measurements in wastewater using different calibration approaches. Water Science \& Technology, vol. 53, no. 12, pp. 187-197.

THOMAS, O., BAURÈS, E. and POUET, M., 2005. UV spectrophotometry as a non-parametric measurement of water and wastewater quality variability. Water Quality Research Journal, Canada. vol. 40, no. 1, pp. 51-58.

THOMAS, O., THERAULAZ, F., CERDA, V., CONSTANT, D. and QUEVAUVILLER, P., 1997. Wastewater quality monitoring. Trends in analytical chemistry, vol. 16, pp. 419-424.
VAN DER BROEKE, J., LANGERGRABER, G. and WIENGARTNER, A., 2006. On-line and in-situ UV/VIS spectroscopy for multi-parameter measurements: a brief review. Spectroscopy europe, vol. 18, p. 28.

VANROLLEGHEM, P.A. and LEE, D.S., 2003. On-line monitoring equipment for wastewater treatment processes. state of the art. Water Science \& Technology, vol. 47, pp. 1-34. 


\section{Real Time Monitoring of Water Quality in Supply Pipelines and Industrial Facilities}

Calvi, F.A. ${ }^{1,}$, Ramos, G.P. ${ }^{2}$, Tundisi, J .G. ${ }^{3}$, G higlieno, F.G. ${ }^{1}$

IFederal University of São Ca rlos, Department of Physics, São Ca rlos, SP - Bra zil 2Pa ulista University, Department of Mechanical Eng ineering, Ara raquara, SP - Brazil 3Intemational Institute of Ecology, São Carlos, SP - Brazil Corresponding author: felipe.calvi@df.ufscar.br

\section{Abstract}

The main goal of this project is to findalow costloT solution for real-time monitoring of water quality. With the support of a sensors network, we should be able to collect inorganic parameters in water for both domestic and ind ustrial a pplic a tions. For the first time, this tool can allow to monitoring and control the water chemical and physic al data along the mains water supply and distribution. The projectrelies on support of development companies such as FAPESP and with collaboration of the Intemational Institute of Ecology in partnership with Matsu-Aquatech and the Innovation Agency of UFSC ar.

Keywords: intemet of things, sensors network, real-time monito ring, water qua lity. 


\section{Introduction}

All living things depend of water to survive and we, human beings, a re not a $n$ exception. However, watergoes beyond our biological needs. We require water in our everyda y activities, from wa shing our dishes, to the cleaning of industrial equipment or dissolution of chemic al drugs. All those processes depend on the water qua lity.

In this context, the applic able local regula tions a im to define standards for the water quality combining several physical and chemic al para meters.

But nevertheless, there is evidence that Huma nity's ina dequate a ctions on the environment impacts the dynamic equilibrium in the Nature. It is a n exa mple the degradation of river waters, which, by the time, have considerably deteriorated due to the precariousness of basic sanitation and the increasing of ind ustrial pollution. Therefore, monitoring of wa ter qua lity is now a mandatory step for the preservation, the analysis and where possible the possible recovery on the basis of safety standards from the Health Ministry (MINISTÉRIO DA SAÚDE, 2011).

\section{Justification}

The a mount of chlorine, well-known bactericide, in the drinking water is one of the parameter available on the water bills in São Carlos. Since December 2015 we have monitored this value and we observed in the region next to the Federal University of Sã o Carlos a n a verage value of $1.2 \mathrm{mg} / \mathrm{L}$, six times $0.2 \mathrm{mg} / \mathrm{L}$, the minimum a mount fixed by SABESP (Ba sic Sanitation Company of the State of Sa o Pa ulo) (SABESP, 2017).

In the scientific literature, it is documented a correlation between an excess of chlorine and the breast cancer (SC IENTIFC AMERICAN, 2017). There is a Iso evidence of that this chemic al element be detrimental to kid neys a nd liver (DEN BESTEN, CATHALINE et al., 1991). In a ddition, the chemical reactions of chlorine with the environment can impact in producing carcinogenic toxins exposed in nature (DREC HSLER, P.A., WILDMAN, E.E. and PANKEY, W., 1990).

Made aware of the consequences for our health and for the environment, we have started to develop a compact, reconfigurable, hot-pluggable and low-cost stations for monitoring in real time the water chemical and physical parameters along the mains water supply in the city (FAPESP - PIPE: 2017/15930-4 and UFSC ar ProEx 23112.003836/2015-99). For this purpose, we work on integrating sensors in an equipment able to measure, record and send data in real time for modeling, monitoring and, if necessary, ta king action. We a re looking for a standardization of water quality verific a tion in our city. The project is interd isc iplinary and takes advantages from the collaboration with the Intemational Institute of Ecology (IIE - São Carlos) and from the support of the company Matsu-Aquatech. 
Methods and Materials

The prototype benefits from sensors both a vailable on the market and self-fabric ated.

A microcontroller ma nages the sensors, extracts and records the data. Firstly, the equipment will be tested and calibrated in the Óptica, LAser Fotônica laboratory - ÓLAF/DF-UFSC ar (see Figure 1) with 'ad-hoc' samples prepared by the Intemational Institute of Ecology. In this way, we expect to reach a high sensitivity, making our a rc hitec tural solution competitive with others, more expensive, available on the market.
In a second stage of the project, the sta tions will be installed in different place along the water supply network. Adopting different solutions depending on the a vailable network facilities, the equipment will transmit processed information (e.g. $\mathrm{pH}$, flux, temperature, etc.) to the data processing workstation.

The collected data are going to be analyzed and modelled by expert in the area. This monitoring facilities will be a precious to ol for all the enterp rises working with water and water distribution.

The authors in collaboration with the Innovation Agency (UFSC ar) work on the documentation to submit the patent to the INPI agency.

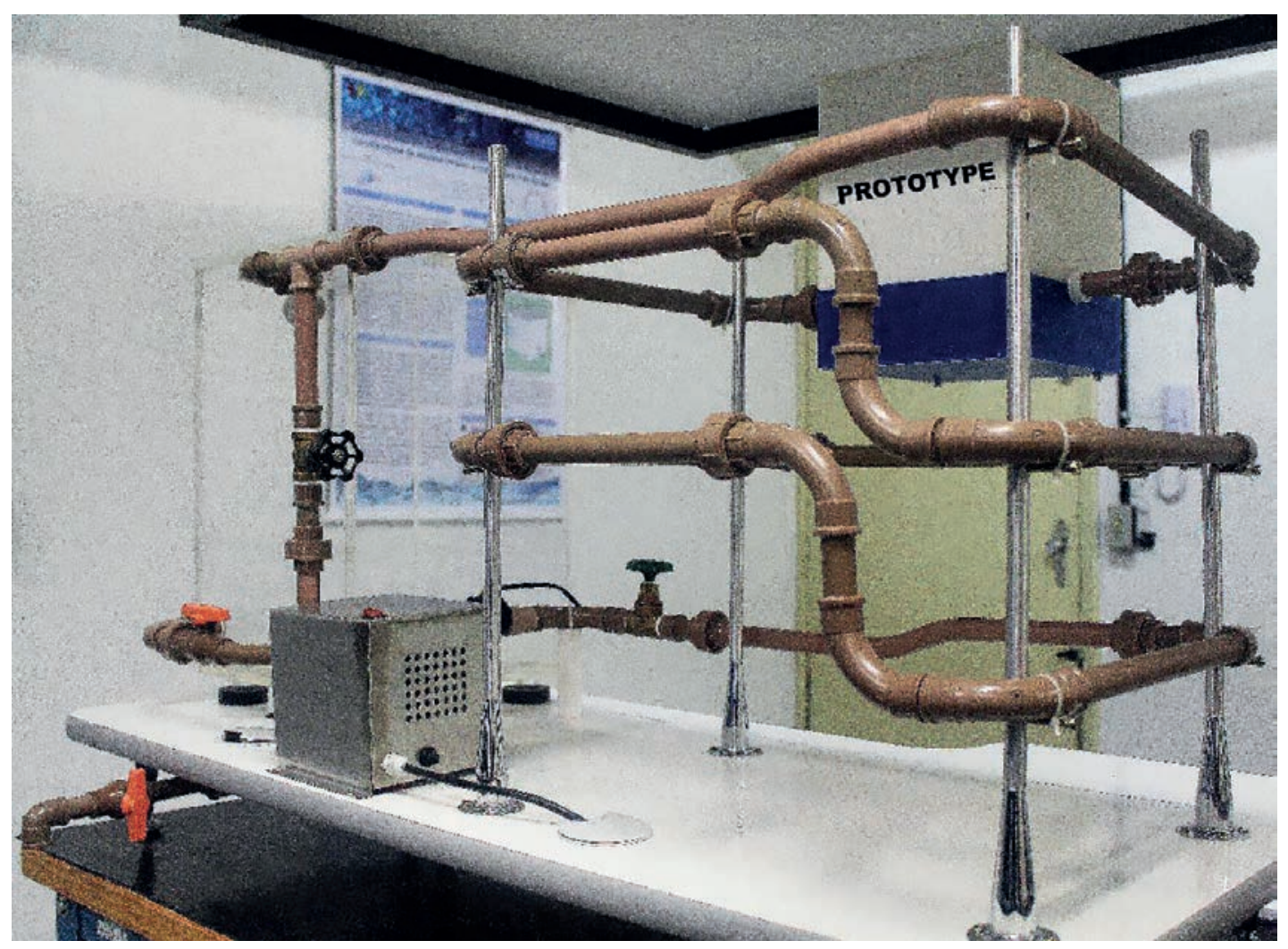

Figure 1 - Testing apparatus for the prototype (courtesy of Laboratório de Óptica, Laser e Fotônica - ÓLAF/DF-UFSCar). 


\section{References}

MINISTÉRIO DA SAÚDE. Portaria no 2914, de 12 de dezembro 2011. Available in: http://bvsms.saude. gov.br/bvs/saudelegis.

SABESP, 2017. Qualidade da água. Available in: http://site.sabesp.com.br/site/interna/Default. aspx?secaold=40. Access: Dec. 2017.

SCIENTIFC AMERICAN, 2017. Tapped Out? Are Chlorine's Beneficial Effects in Drinking Water Offset by Its Links to Cancer? Available in: https://www. scientificamerican.com/article/earth-talks-tappedout. Access: Dec. 2017
DEN BESTEN, CATHALINE et al., 1991. The liver, kidney, and thyroid toxicity of chlorinated benzenes. Toxicology and applied pharmacology, vol. 111, no. 1, pp. 69-81.

DRECHSLER, P.A., WILDMAN, E.E. and PANKEY, W., 1990. Evaluation of a chlorous acid-chlorine dioxide teat dip under experimental and natural exposure conditions. Journal of Diary Science. 


\section{Preliminary Study of a Low-Cost, Easily-Implementable Alternative for Waterbody Restoration}

Bertho, G.G.1

IIntemational Institute of Ecology and Environmental Management - IIEGA, Rua Bento Carlos, 750, Centro, CEP 13560-660, Sã o Ca rlos, SP, Bra zil

*Correspoding a uthor: gabsbertho@hotmail.com

\section{Abstract}

As the population increasingly grows, the impacts of climate change rise and the lack of clean water start to surround us, the need for the restoration of waterbodies increase. Thus, new technologies have to be developed a iming to improve the water quality of rivers and boost its natural recovery. The objective of this prelimina ry study was to develop a cheap and accessible altemativeto improve the water quality of rivers and lakes by using low-cost waste materials. Experiments were conducted to observe the decrease of organic matter of biofilms supported in coconut fibers and in P.U spongesthrough time. Both biofilms presented high degradation efficiencies and at low contact times. The biofilm in coconut fiber showed a higher average organic matter degradation rate, but the biofilm in P.U sponges showed a higher decrease of coloration and odor. A structure was created to simulate the condition of a river and both materials were placed into it in order to a nalyze their effic iency. The results showed considerable decrease in nutrients, organic matter, suspended solids, turbidity and coloration. Considering the system had a relatively high flow rate, thus not allowing the water to have contact with the structure for a long time, these results establish that the structure could be applied in a real effluent to improve the water quality. However, further research is needed to a nalyze the effects of more variables and establish some strategies of how this should be applied in a real waterbody.

Keywords: waterbody, restoration, low-cost, biofilm, coconut, polyuretha ne. 


\section{Introduction}

Considering the increasing impacts of climate change, the population growth and the quantity of rivers and lakes that c urrently a re eutrophic, the efforts conceming river restoration have to be one of the main focuses of environmental engineers.

Govemment agencies and stakeholders recognize the importance of river restoration for the conservation of the environment. However, even with legal mandates, massive expenses, and the emerging industry of ripa rian restoration, a qua tic ecosystems continue to deteriorate due to human influences (KARR, CHU, 1999).

According to the la test survey of Fundação SOS Mata Atlântica, of the water a nalyzed in 184 rivers, strea ms and lakes of 11 Brazilian States and the Federa I District, $27.5 \%$ showed poor qua lity, $70 \%$ showed regular quality and only $2.5 \%$ showed good quality (FUNDAÇÃO SOS MATA ATLÂNTICA, 2017).

When a river or strea $m$ is degraded, we lose many of the ecosystem services that a re essential to soc iety (BARON et al. 2002). River restoration a ims to recoup some of these losses and to do it in more public acceptable ways and at lower costs than through technologic al fixes such as waste treatment plants (PALMER et al. 2004).

During the last decades, the use of aquatic macrophytes to improve the quality of water bodies has been very suc cessful. These a quatic plants and the mic roorga nisms associa ted to its roots can effec tively decrease the qua ntity of nutrients, organic matter, heavy metals and turbidity of the water (SRIVASTAVA, CHANDRA, 2008). By improving the water quality, the aquatic environment can effectively sta rt to recover itself. Thus, the use of macrophytescan offer a good altema tive for effluent resto ration, however the implantation and the accessibility of this technology is not fla shy in some regions. Additionally, the macrophytes when saturated need to be replaced by new ones and they can become haza rdous boosters for eutrophic ation if not controlled properly.

In order to conserve the environment and ensure the availability of water resources to any being in the future, new technologies have to be developed to improve the water quality of the a quatic ecosystems. These technologies can either be an alternative for the use of macrophytes or be used a long with these plants. Any proper effort in the restoration of water bodies is valuable to augment the alrea dy strained water resource portfolios and preserve the diversity of not only the rivers, streams and lakes, but also the wetlands, forests and swamps interconnected to them.

\section{Objective}

Aiming to restore the water quality of rivers, prevent eutrophic ation and thus help ensure the availability of water resources to any living being in the future, this preliminary work has the object of developing a low-cost altemative method 
to reduce the concentration of organic matter, turb idity, coloration, suspended solids and nutrients of river waters using waste materials that are in abundance in Brazil.

\section{Methodology}

\section{Sampling}

Sampleswere collected from three main sources. The first source was the Gregorio River in which the sampling point was near a settlement called SESC, in the center of Sã o Carlos, SP, Bra zil. The sec ond so urce was the Mojolinho River in which the sampling point was in a course neara lake located inside the Federa I University of Sã o Carlos. The third source was the sewage from São Carlos's neighborhood Santa Felicia which was provided by the Department of Environmental Engineering of the University of Sã o Paulo. The samples were collected with buckets and stored in sterilized fla sks.

\section{Effect of time on organic matter degradation of biofilms supported in coconut fibers and polyurethane sponges}

A study in laboratory scale was made to evaluate the degradation of organic matter of biofilms supported in coconut fibers and polyurethane (P.U) sp ong esthro ug htime.
Twenty liters of water from the Gregorio River collected as described in this methodology before were flowed in an inert water tank, and then 200 grams of coconut fiber were added to the tank. Ana lysis of Bioc hemic a I Oxygen Demand (BOD) wasmade in the raw sample of the river water and then the same analysis was made in the water sample after 30 minutes, 1, 2, 3 and 5 hours of contact with the coconut fiber. The figure below portrays the watertank with the coconut fibers inside.

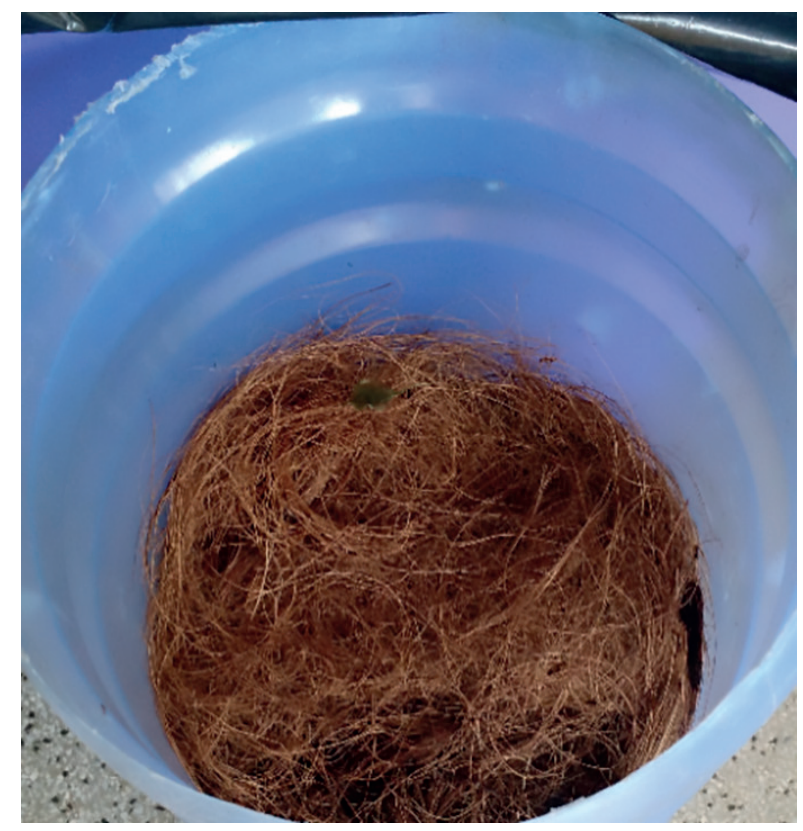

Figure 1 - Water tank with coconut fibers.

To compare the efficiency of organic matter degradation of the biofilms, twenty liters of the sa me water from the Gregorio River were flowed in a second inert water tank, and then 150 grams of P.U sponges were added to the tank. The sponges were cut into small pieces to allow water flow and the pieces were wrapped with a nylon cloth to prevent the water from floating the sponges up. BOD a nalysis was made 
in the raw sample of the river water and then the same analysis was made in the water sample after 30 minutes, 1, 2, 3 and 5 hours of contact with the P.U sponges. The figure below portrays the water tank with the sponges inside.

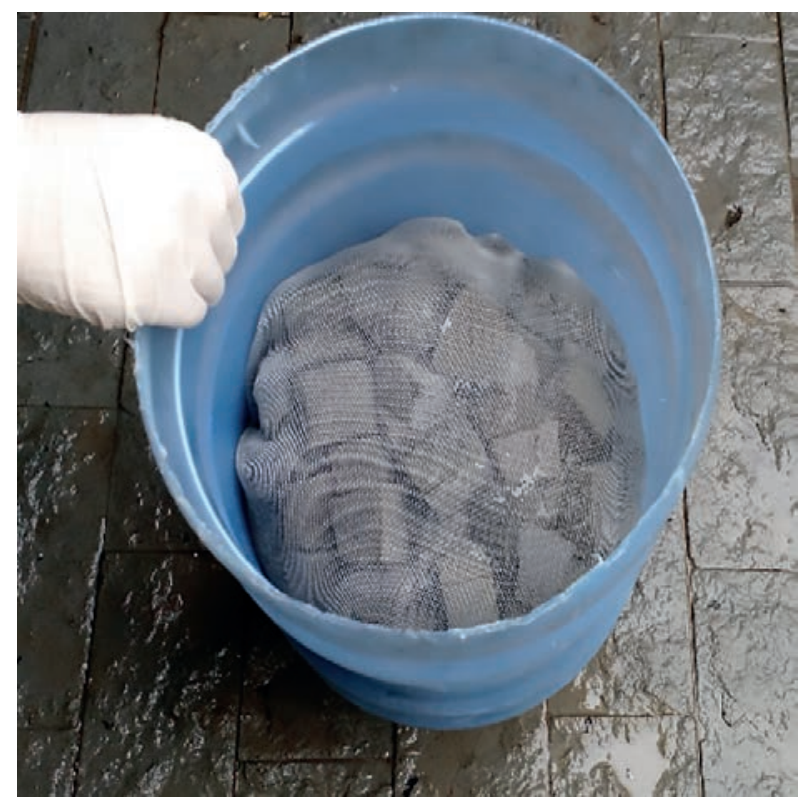

Figure 2 - Water tank with P.U sponges.

\section{Development of a biofilm cel1}

In order to create a "biofilm cell" which would be applied directly in the effluent to enhance its quality, the following materials were used: coconut fibers, polyuretha ne sponges, nylon cloth and PVC tubes. The coconut fibers and the P.U sponges were previously left for 7 days in contact with organic matter and mic roorga nism from a São Carlos water river sample (Monjolinho River); afterward, both materials were wrapped in a nylon cloth in order for them not to disperse in the water. In each biofilm cell, 100 grams of coconut fiber and 50 grams of P.U sponges were used. The sponges were disposed more at the top and the bottom of the cell; the coconut fibers were disposed at the center. It was made because biofilms created in coconut fibers a re more efficient in the degradation of organic matter and the biofilms in the P.U sponges are more efficient in the reduction of coloration and turbidity as detected before in this study. This a rrangement a llows the water to have a greater contact with the coconut fiber while its suspended solids a re reta ined by the P.U sponges. The PVC tube would be the support for the cell, and would be attached to the nylon cloth. The figure below outlines the biofilm cell.

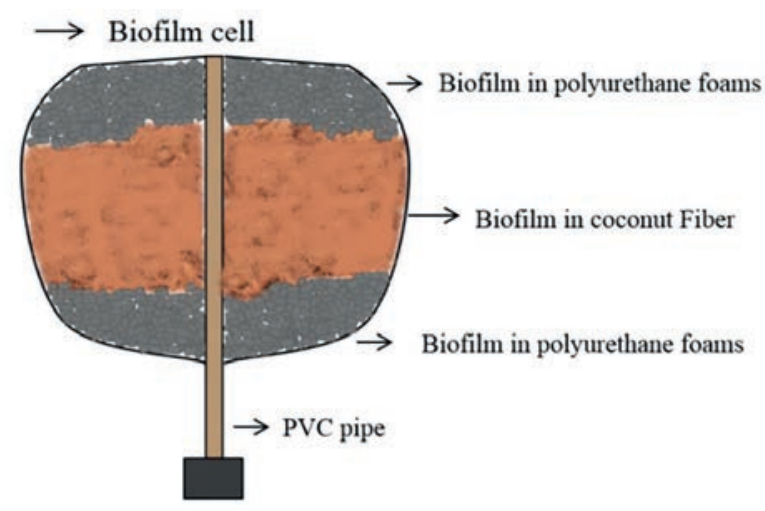

Figure 3 - Biofilm cell.

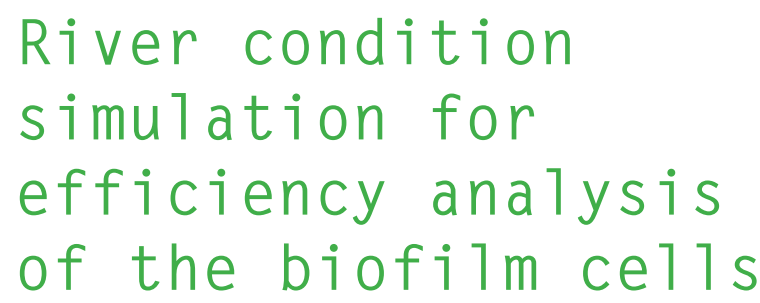

Aiming to evaluate and establish the efficiency of the biofilm cells in the improvement of river's water, a structure was developed to simula te the condition of a n effluent. The following materia ls were used: three wooden planks (Dimensions of $30 \times 70 \mathrm{~cm})$, impermeable plastic canvas, 
50-liter wa ter ta nk and wooden supports. The planks were nailed together to form a rectangle without its to $p$ face and the plastic canvas was used to clothe the wood and prevent water absorption by it. The water tank was attached to one side of the structure and an opening was made on the other side. The biofilm cells would be placed in the middle of the system, the contaminated water would be dispensed from the tank and the treated water collected at the other side asillustrated in the figure below.

For an initial effic iency test, 5 biofilm cells were placed in the center of the simulator structure. Sewage collected in the University of Sã o Paulo as described before was taken to a nalysis in triplicate of biological oxygen demand (BOD), elec tric al conductivity, total suspended solids, turbidity, coloration, phosphorus, and nitrate. Afterwards, the sewage waspoured with constant flow in the simulation system and the treated water was taken to the same analyses of the raw sample. The inlet flow rate was approxima tely $20 \mathrm{ml} / \mathrm{s}$ and the samples analyzed were only collected when 5 liters of wa ter had a Irea dy left the system in order to ensure that the system was already stabilized. A total of 3 trea ted water samples were collected.

\section{Laboratory analysis}

The laboratory a nalyses were all conducted in the Intemational Institute of Ecology. Analysis for biochemical oxygen demand (BOD) began within $24 \mathrm{~h}$ of sample collection using the 5-day BOD test (APHA, 1998). Elec tric a I C onduc tivity was measured using a Digimed EC meter. Turb id ity was measured with a Hach 2100P Turbid imeter using nephelometric methods. Coloration wasmeasured with a calibrated Hach DR3900 spectrophotometer. The Total Suspended Solids (TSS) was a nalyzed using the Standard method 2540D. Finally, for ana lysis of nutrients, $30 \mathrm{ml}$ a liquots were used and a nalyzed by the method of digestion with Pota ssium Persulfate (VALDERRAMA, 1994), followed by colorimetric reading in the form of nitrate or phosphate as described in Strickland and Parsons (1972).

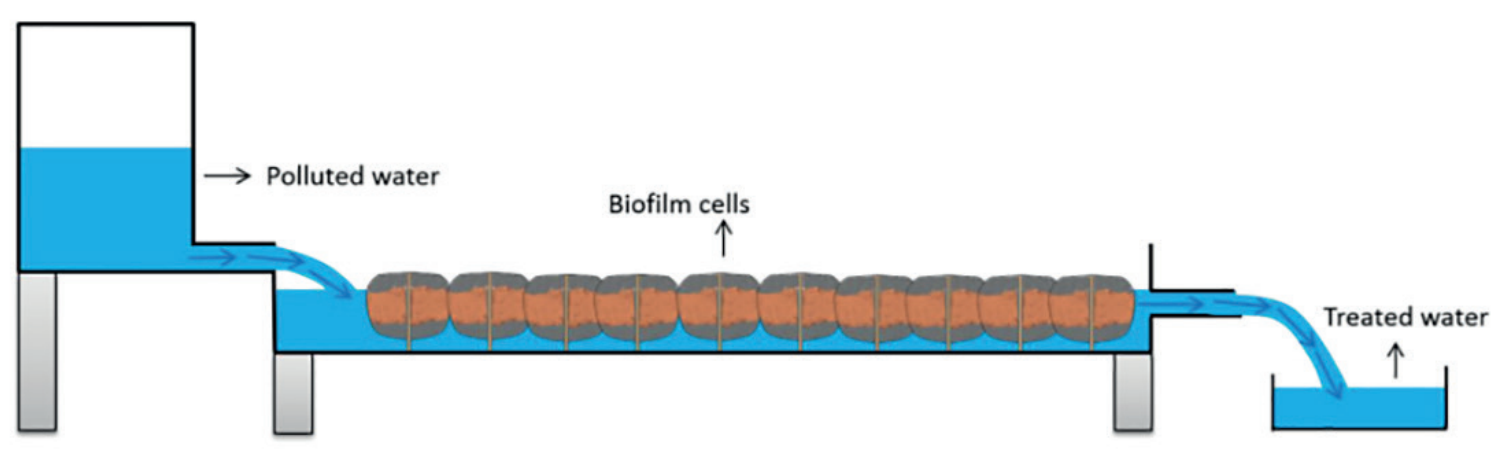

Figure 4 - Structure to simulate a river condition. 


\section{Results and Discussion}

\section{Effect of time on}

\section{organic matter}

degradation of

biofilms supported

in coconut fibers

and polyurethane

sponges

The following graph deploys the results of the BOD a nalysis made to evaluate the effect of time in the organic matter degradation of the biofilms as described in the methodology and a line of best fit.

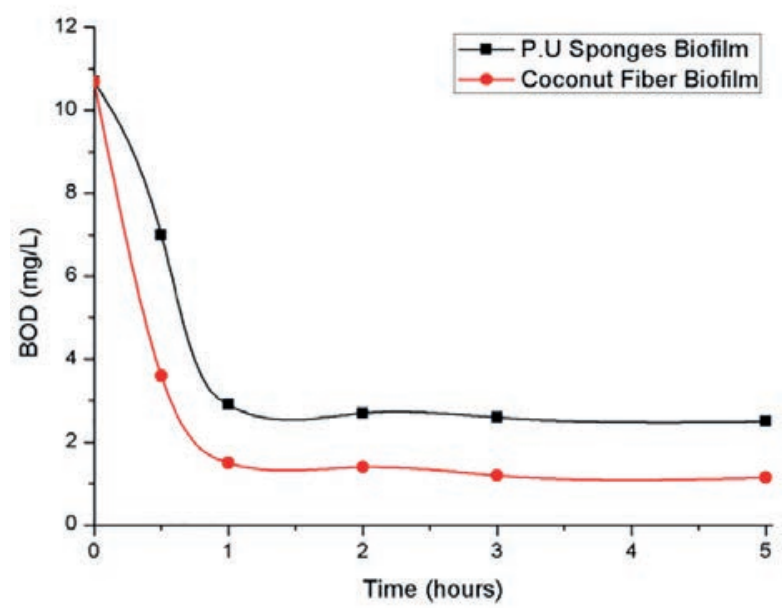

Figure 5 - Graph of BOD throughtime ofwater samples in contact with coconut fiber and P.U sponges biofilms.

As shown in the graph, the organic matter concentration decays exponentially in the first hour and then remains a lmost static in the next hours.An explanation for this may be that the remaining organic matter after the first hour werePersistent organic pollutants (POPs), therefore the biofilms were not able to degrade it rapidly. The biofilm supported in coconut fiber had an average organic matter degradation rate greater than the biofilm supported in the P.U Sponges. The pores of the coconut fibers a re smaller than the ones of the P.U sponges, this makes the fibers more suita ble for mic roorga nisms and expla ins why the coconut fibers had a greater total effic iency for $B O D$ reduction. However, the coloration and the odor of the water were observed todecrease faster in the biofilm supported in P.U sponges, establishing that it conta ins mic roorganisms of different functions compared to the ones in the coconut fiber.

These results demonstrate that the biofilms can have potential uses in river restoration once the degradation time was relatively slow for high effic iencies, what is an essential fea ture for their a p liance in water bodies.

\section{Efficiency analysis}

The following table displays the results of the laboratory analyses of bioc hemic al oxygen demand (BOD), electric al conduc tivity (EC), turbidity, coloration, total suspended solids (TSS), total phosphorus and nitrate in the samples collected to evaluate the effic iency of the biofilms cells as desc ribed in the methodology. The results shown a re the arithmetic mean of the results of all a nalyzed samples. 
Table 1 - Laboratory analysis results of samples in the efficiency analysis.

\begin{tabular}{lcc}
\hline & Raw Sample & After treatment \\
\hline BOD $(\mathrm{mg} / \mathrm{L})$ & $34,82 \pm 1.21$ & $23.42 \pm 2.40$ \\
\hline $\mathrm{EC}(\mu \mathrm{S} / \mathrm{cm})$ & $260.2 \pm 0.74$ & $218.1 \pm 7.24$ \\
\hline Turbidity $(\mathrm{NTU})$ & $50.2 \pm 0.08$ & $28.6 \pm 2.08$ \\
\hline Coloration $(\mathrm{Pt} / \mathrm{Co})$ & $80.2 \pm 0.14$ & $54.9 \pm 0.78$ \\
\hline TSS $(\mathrm{mg} / \mathrm{L})$ & $30.00 \pm 1.75$ & $10.67 \pm 1.24$ \\
\hline Total Phosphorus $(\mu \mathrm{g} / \mathrm{L})$ & $840.2 \pm 32.60$ & $730.1 \pm 37.10$ \\
\hline Nitrate $(\mathrm{mg} / \mathrm{L})$ & $5.04 \pm 0.29$ & $4.12 \pm 0.23$ \\
\hline
\end{tabular}

As shown in the table, the biofilm cells are efficient at improving the water quality, having a $\mathrm{n}$ efficiency of $32.73 \%$ in the reduction of BOD, $16 \%$ in the reduction of electric al conductivity, $43 \%$ in the reduction of turbidity, $31.5 \%$ in the reduction of coloration, $64.4 \%$ in the reduction of suspended solids, $13.1 \%$ in the reduction of phosphorus and $23.6 \%$ in the reduction of nitrate.

The decrease in BOD reveals that the mic roorganism established in the biofilm cells can effectively and rapidly degrade organic matter. The reduction of nutrients in the water is reflected in the fact thatthe coconut fiber can act as a natural biosorbent of nutrients due to its physical and chemic al properties (LO MONACO, MATOS, SARMENTO, LOPES J ÚNIOR, LIMA, 2009). Considering the simula tion system was with a rela tively high flow rate, hence not allowing the water to have contact with the coconut fibers and the P.U sponges for a long time, the reduction of organic matter, nutrients, and suspended solids show the potential of the biofilm cells of reducing these parameters in a real river condition, where the contact time will be even lower. The more biofilms cells in the system, the more it is expected to have higher efficiencies once there will be more microorganisms and more absorbent ma teria ls a vailable. Therefore, these results show that the biofilm cells can be applied to improve the water quality of effluents.

\section{Conclusion}

Biofilms sup ported in coc onut fibers and polyurethane sponges are efficient in the degradation of organic matter and the contact time needed to achieve great decrease percentages is relatively low. The biofilm supported in coconut fibers is more effic ient at the decrease of BOD, but the biofilm supported in the P.U sponges is more efficient in the decrease of coloration and odor. By gathering both materials and applying them in a river simulating condition, it was possible to detect their effic iency in the reduction 
of organic matter, suspended solids, turbidity, coloration, and nutrients. The results gathered showed relatively great effic iencies to all parameters studiedand the contact time of the water with the materia ls was very low, what revea ls the potential use of these materials to improve the water quality of waterbodies and thus boost its restoration.

The struc tures developed and studied in this preliminary work could either be applied directly in a river or applied a long with floating macrophytes in order to a chieve greater effic iencies. Thestructures a re easy to implement, have a low-cost, and should be placed in several parts of a river or lake, to the reby gradually improve their water quality. However, further research is needed to establish the relationship between the number of

\section{References}

BARON, J.S., POFF, N.L., ANGERMEIER, P.L., DAHM, C.N., GLEICK, P.H., HAIRSTON, N.G., JACKSON, R.B., Johnston, C.A., Richter, B.G. and Steinman, A.D., 2002. Meeting ecological and societal needs for freshwater. Ecological Applications, vol. 12, pp. 1247-1260.

BERNHARDT, E. S., SUDDUTH, E.B., PALMER, M.A., ALLAN, J.D., MEYER, J.L., ALEXANDER, G. et al., 2007. Restoring rivers one reach at a time: results from a survey of U.S. river protection practitioners. Restoration Ecology, vol. 15, pp. 482-494.

FUNDAÇÃO SOS MATA ATLÂNTICA, 2017. Observando os Rios 2017. O retrato da qualidade da água nas bacias da Mata Atlântica. Available in: https://www. sosma.org.br/projeto/observando-os-rios/analiseda-qualidade-da-agua/. Access: Sep. 2017. biofilm cells and the system efficiency, the influence of the waterflow rate, the influence of $\mathrm{pH}$ and temperature, the potential decrease of heavy metals and the maximum usage time of the biofilm cells.

\section{Acknowledgement}

This resea rch was partially supported by the Internationa I Institute of Ecology (IIE). I tha nk my collea gues from IIE who helped me in the experiments execution and la bora tory a na lysis, especia lly Leandro Campanelli, who accompanied me in all laboratory a nalysis and provided full support. I would also like to show gratitude to Prof. J osé Galizia Tundisi, who provided me the use of the laboratory, supported the funding and gave me the opportunity of publishing this paper.

KARR, J.R. and CHU, E.W., 1999. Restoring Life in Running Waters: Better Biological Monitoring, Island, Washington, D. C.

LO MONACO, P.A.V., MATOS, A.T., SARMENTO, A.P., LOPES JÚNIOR, A.V., and LIMA, J.T., 2009. Desempenho de filtros constituídos por fibras de coco no tratamento de águas residuárias de suinocultura. Engenharia na Agricultura, Viçosa, vol. 17, no. 6, pp. 473-480.

SRIVASTAVA, J., GUPTA, A. and CHANDRA, H., 2008. Managing water quality with aquatic macrophytes. Reviews in Environmental Science and Bio/Technology, vol. 7, no. 3, pp. 255-266. 


\section{The Use of Geotechnologies In the Environmental Vulnerability Diagnosed in Sustainable Use Conservation Unit}

Siqueira, H.E. ${ }^{1}$, Pereira, G.T.2 ${ }^{2}$ Pissa rra, T.C.T. ${ }^{3}$, Valle J unior, R.F. ${ }^{4}$, Santi, G. L. D. ${ }^{5}$, Campos, C.A.A. ${ }^{6}$

${ }^{1}$ Doctorate in Agronomy (Soil Science)na Faculdade de Ciências Agrárias e Veteriná rias - FCAV-UNESP, Campus de J a botic a bal - SP, Bra sil.

2Prof. Dr. at the Faculda de de Ciências Agrárias e Veterinárias - FCAV- UNESP, Campus de J abotic a bal - SP, Brasil.

${ }^{3}$ Profa. Dra. at the Faculdade de Ciências Agrárias e Veterinárias - FCAV- UNESP, Campus de J aboticabal - SP, Brasil.

${ }^{4}$ Prof. Dr. at the Instituto Federal do Triângulo Mineiro - Campus Uberaba, MG, Brazil.

${ }^{5}$ Student in Geography at Universidade Federal do Triângulo Mineiro, Uberaba-MG, Brazil.

${ }^{6}$ Prof. Dr. of Universida de Federal do Triângulo Mineiro, Ubera ba-MG, Brazil.

Corresponding autor: hygorsiqueira@ya hoo.com.br, genertp@fc av.unesp.br, teresap@ fcav.unesp.br, renato@iftm.edu.br, giulia.deisanti@gmail.com, carlos.campo@uftm.edu

\section{Abstract}

The misuse of agric ultural a ctivities has been a cause for concern a s to the risks of contamination of soil and water, with possible health and environmental impacts. The objective of this study was to verify the enviro nmental vulnera bility of water reso urc es in the Environmental Protection Area of the Uberaba (APA). The condition of risk and fra gility that the environment is found was determined using the multic riteria modeling 
of morphometric parameters and soil occupation, and data a nalysis was performed in a geographic information system (GIS) platform. The intervening factors selected for a nalysis were: draina ge density, slope, soil classes, distance of water lines and land use and occupation. It was possible to jointly evaluate the different information plans and to generate from the multic riteria the vulnerability of the water resources in the APA.

Keywords: information system, morphometry, conservation planning, multiple criteria.

\section{Introduction}

Environmenta I vulnerability refers to the risk of degradation of the natural environment, related to soil erosion, loss of biodiversity, soil and water resources contamination and loss of vegetation cover exacerbated by anthropogenic factors, which may result in the loss of biodiversity and compromise the quality and quantity of na tural reso urces (COSTA et al., 2007).

Multic riteria decision modelling (MCE) based on the geographic information System is the basis of decision-making, and the weighted Linearcombination (WLC) is one of the basic methods, which makes Exchange of factors "with each other". Modeling is an important tool for the study of environmental a nalysis (VELDKAMP, LAMBIN, 2001). This methodology provides altemative techniques to incorporate decisions preferences in the environmental assessment process. Thus, the objective of the use of MCE model is to find solutions to the problems of decision making characterized by multiple alternatives, which can be evaluated by using decision criteria (PINTO, 2010, BOTTERO et al., 2013).

Fuzzy logic, drawn by Zadeh (1965) became an important topic of research during the Decade of 1980 for use in GIS and environmental a dequacy a nalysis. Consists in algebraic logic analyses of maps, sustained by the simila rity Bayesian probability and Boolean, generating maps by map cumulative algebra through the standardization of the variables used, converting the data values unique in fitness values to the desired purpose.

Several researches in different areas were developed using MCE. Such studies in a gric ulture (AKINCI et al.; 2013, DRAGINCIC et al.; 2015;), soil conservation and fitness (VALLE J UNIOR et al.; 2014;), irrigation (CHEN, PAYDAR 2012), conservation of water reso urces (VALLE J UNIOR et al.; 2015; CALIZAYA et al.; 2010), conservation of natural resources and forestry (Bottero et al.; 2013; KAYA and KAHRAMAN 2011), transport and industrial projects (MACHARIS et al. 2012), Ec onomic s (MARTIN-ORTEGA, BERBEL 2010; ZUBARYEVA et al.; 2012) a mong others, showed the functionality of the multi-criteria a nalysis in decision making in different applic ation a reas.

The APA of Uberaba River just had a recognition and concem in 2003, in which in the Alegria, this basin in the APA, there was a derailment of a freight train, and this accident is considered 
the la rgest environmental disa ster of the TriânguloMineiro until the present day. The charges were made up by the octanol $\left(\mathrm{C}_{8} \mathrm{H}_{18} \mathrm{O}\right)$, methanol $\left(\mathrm{CH}_{4} \mathrm{O}\right)$, ISO-buta nol $\left(\mathrm{C}_{4} \mathrm{H}_{10} \mathrm{O}\right)$ and potassium chloride $(\mathrm{KCl})$ in which, with the accident, an explosion occurred and which devastated more than 1000.0 m of native vegetation, as well as deposit and disperse more than $670 \mathrm{~kg}$ of contaminants in soil and water. Public water supply was intemupted for more than 5 days and it was decreed a State of public calamity. In this period the lack of water was supplied by water trucks, however, insuffic ient. More than 250,000 inhabitants were impacted by the lack of water due to this accident and the contamination of water resources.

The a im of this paper is to draw up the diagnosis of environmental vulnerability of water resources from the multi-criteria modeling of physical parameters and microbasin in the APA morphometric of Uberaba River, through the use of GIS.

\section{Area of study}

Their diagnosis of vulnerability of water intercepted by highways in Environmental Protection Area APA of Uberaba River (Figure 1) which is part of the Uberaba River basin, located between the geographical coordinates $19.51^{\circ}$ and $19.74^{\circ}$ South and 47.64 and $47.98^{\circ}$ West of $G$ reenwich in the city of Uberaba-MG.

With a total a rea of $525.27 \mathrm{~km}^{2}$, the APA of Uberaba River has 62 mic roba sins, bounded from the main course, which contribute significantly to the quantity and quality of water reso urc es which supplies the city of Uberaba.

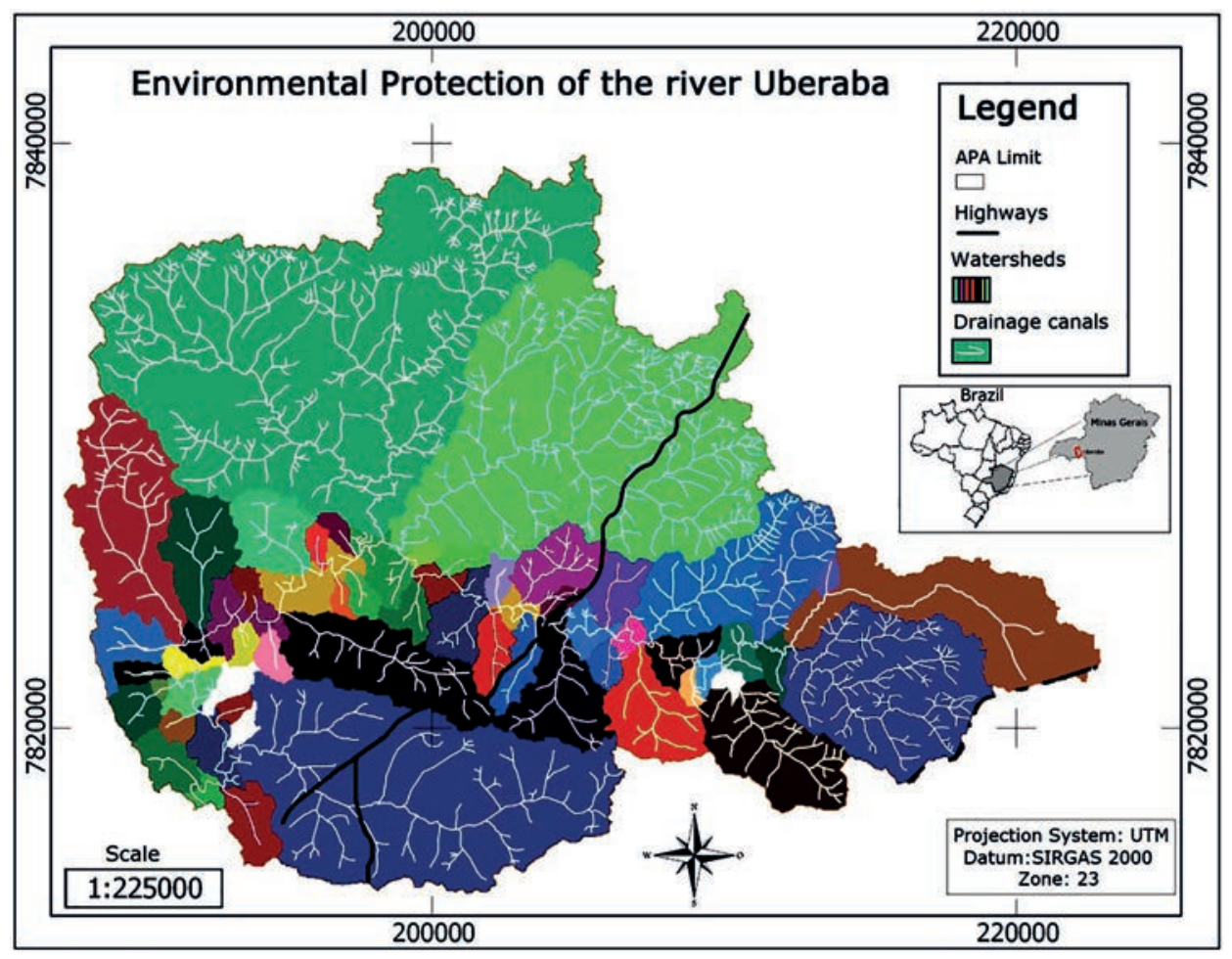

Figure 1 - APA of Uberaba River. Source: Siqueira. 
The climate of the region is classified according to the Köppen type Aw-hot humid tropical, with cold winter and dry, being the domain ranking the humid clima te with 4 to 5 dry months (ABDALA, 2012). The average annual precipitation varies between 1300 and $1700 \mathrm{~mm}$ in the rainy period corresponds to the warmest period of the year. Therefore, there is a characteristic ra iny scheme from October to March and a dry season from April to September. The months of December and J anuary are the rainiest.

The munic ipality of Uberaba is located in Sandstone Plateau Basalt relief of the Paraná basin with soil showing varied characteristics. Most have average texture, ranging from sandy to clay and are classified, in general, as the presence of mic roaggregates showing varying degrees of fertility, with a predominance of Red La tosol Distroférrico medium-textured, Red La tosol typic al and Acrisol Red-Yellow La tosol (NISHIYAMA, 1998).

Cruz (2003) points out that the topography is characterized by flat or slightly wa vy surfa ces, geologic ally formed by sedimentary rocks, basic ally the sandstone, the Cretaceous Bauru formation.

\section{Materials and Methods}

Multi-Criteria Analysis

The Idrisi G IS features integrated image processing feature for analysis and visua lization of spatial data, developed by resea rc hers at CLARK LABS, Depa rtment of geography, Clark University, Worc ester,
MA. In a ddition to the GIS a nalysis modules, image processing, surface analysis, change and time series a nalysis and modeling, the Idrisi providesa set of useful tools to support the decision-making process. In particular, it provides functions to implement the objective evaluation weighting procedure multi-criteria, standardization and diffuse set of criteria for aggregation. The Weighted Linear combination (WLC) present in the module, multiple criteria evaluation (MCE) of Idrisi J ungle, made it possible for this type of work (EASTMAN, 2012).

Second Malc zewski (1999) and Garfi et al., (2011), multic riteria methodology, the developed model follows three phases: (1) selection of the criteria (factors and constraints) for the a nalysis a nd creation of raster maps; (2) a ssignment of weight to each criterion; (3) combination of criteria and creating the final suitability map. In general the methodological process of multi-criteria analysis can be observed as shown in Figure 2.

\section{Data acquisition and choice of factors and constraints}

It was determined for this study of environmental vulnerability of water resources in APA of Uberaba River the acquisition and preparation of thematic mapping of physical factors and watershed morphometric totaling 5 (five) factors (dra inage density, distance from watercourses, slope of the land, use and occupation of the soil and soil classes) and 1 (one) constra int (dra ina ge networks). The restriction was used to the water courses were not classified in classes of vulnera bility. 


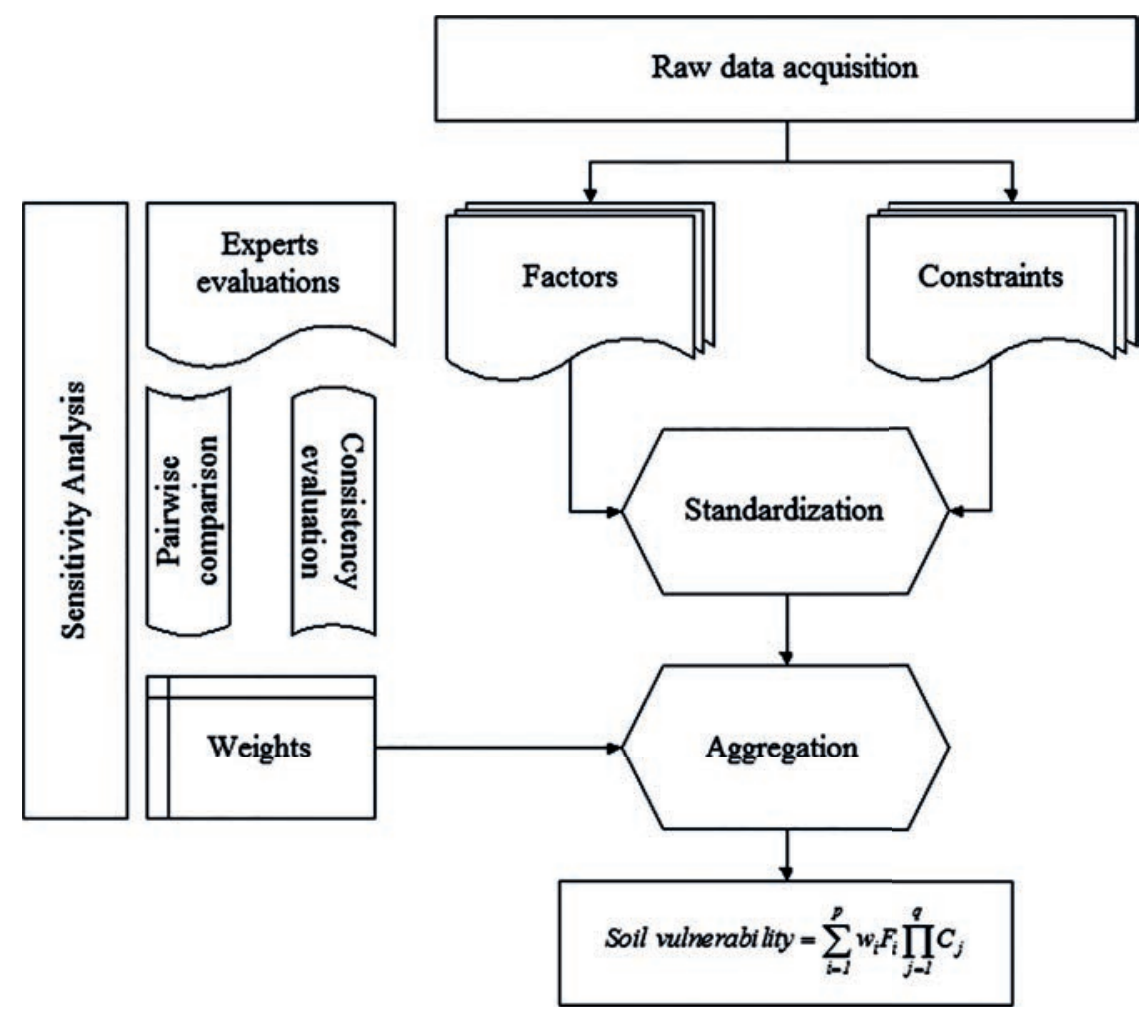

Figure 2-Methodological process of multi-criteria analysis. Source: Adapted from Siqueira et al. (2017).

The map of the drainage network (Figure 3 ) in the a rea under study was drawn from the Digital Elevation Model-DEM, rendered image of the Aster GDEM Sensor (Digital G lobal Elevation Model), at the geographic information System - GIS. The vector file of drainage was exported to the "Google Earth", which has made checking and modific ation, when necessary, of the respective watercourses. Subsequently, exported the vectorfile (drainage network) for the GIS Idrisi J ungle, being this the Cartographic base for the development of the database.

The demarcation of the mic robasin of the study a rea were performed from the DEM, in GIS Id risi J ungle, through the "Watershed". Once generated the information flow was traced the point closest to the exhilarating (mouth) of each watershed with the main course of the Uberaba River and using "Watershed" was bounded each hydrographic watershed.

Dra inage density corresponding to relative to the total length of the channels $(\Sigma \mathrm{L})$ in $(\mathrm{km})$ and the area of the watershed $(A B H)$ in $\left(\mathrm{km}^{2}\right)$ (C HRISTO FO LETT, 1980), was calculated on the following formula:

$$
D d=\sum L / A B H \quad \text { Eq. } 1
$$




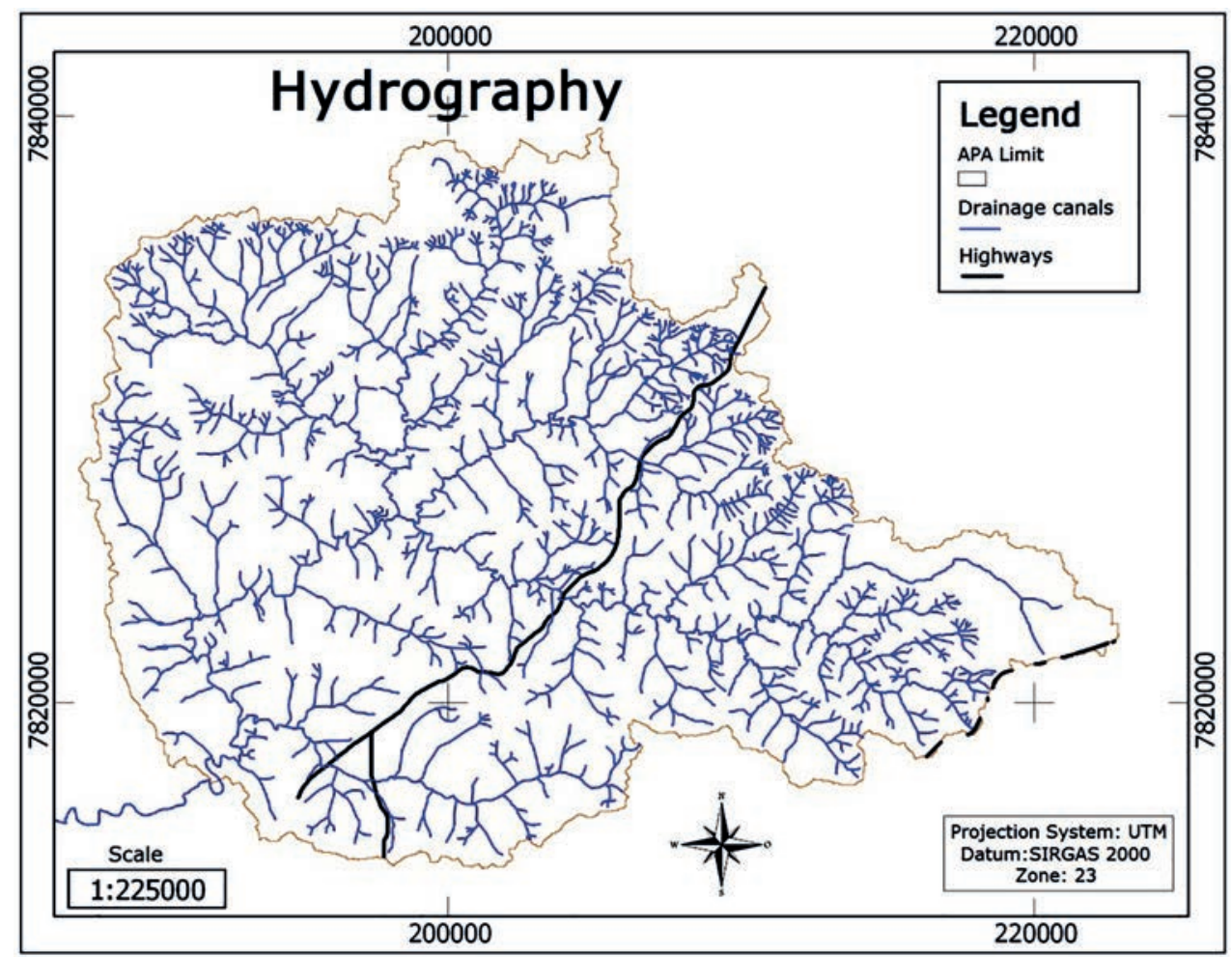

Figure 3 - Map of the APA of Uberaba River drainage.

The data were obtained from the morphometric study of the APA of Uberaba River mic robasin. Using vector files of drainage networks and proceeded to read of the lengths of each strand of mic robasins in AutoCad softwa re by the command "Modify-Lengthen." The a rea of the basin was a utomatically calculated in the GIS with the tool "area".

The values of the density of each drainage basin of the APA were classified according to the criteria described by Vilela and Mattos (1975), such that the ind ex of Dd varies from $0.5 \mathrm{~km} . \mathrm{km}^{-2}$, for with poordrainage basins, the 3.5 ormore, for exceptiona lly well dra ined basins. Wa sheld on Standardization of information plans where the drainage density values were rec lassified as shown in Figure 4.

The map of the distance from the waterline (Figure 5), drawn from the dra inage networks, originated from GIS Idrisi J ungle by distance operation menu "Buffer". Generated from the "Buffer" command the matrix file from distances of $30,50,100,150$ and 200 meters.

The map of slope land was drawn from the DEM where was applied in the GIS image clipping of the study a rea. With the use of the "Slope" tool in the GIS were generated in percentages the land slope classes. After raised the percentages of dec livity was conducted the reclassific ation 
of slope classes using the reference ranges of EMBRAPA (1999) described in Table 1 and illustrated in Figure 6.

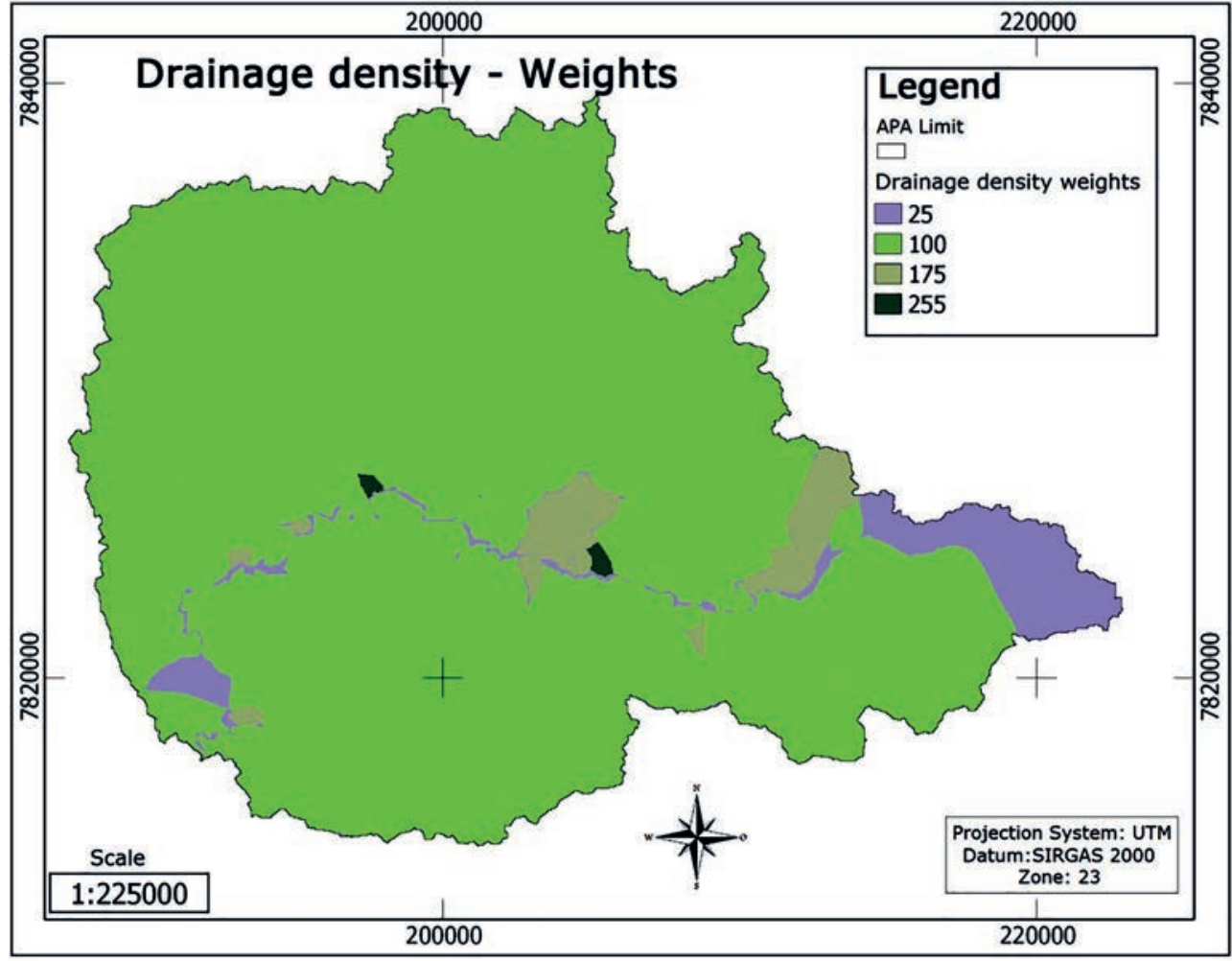

Figure 4-Map of drainage density of the APA of Uberaba River.

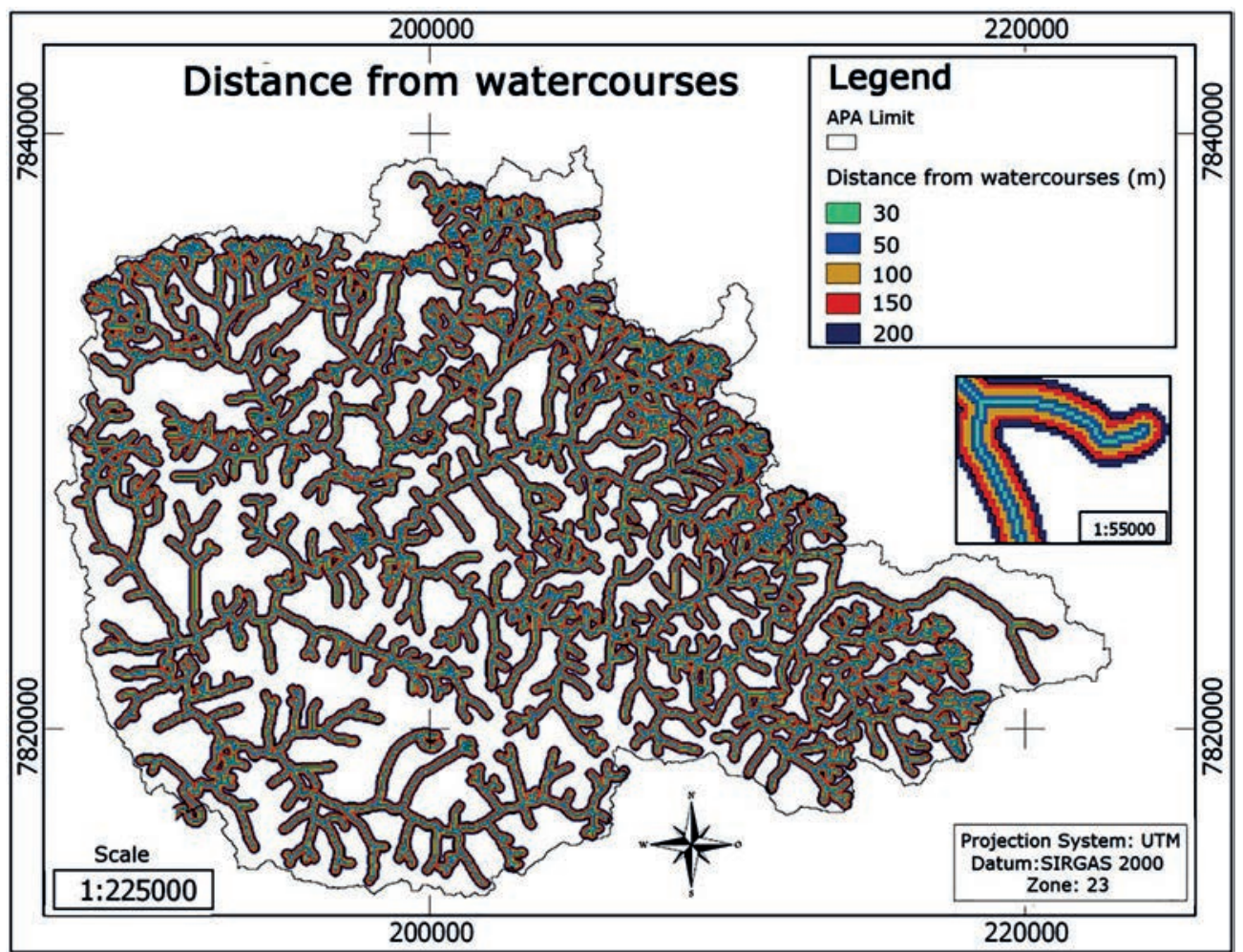

Figure 5 - Map of the distance from the waterline. 
Table 1 - Class intervals of slope and its corresponding reliefs.

\begin{tabular}{cc}
\hline Slope & Discrimination \\
\hline $0-5$ & Relief plan the gentle wavy \\
\hline $5-10$ & Gently rolling relief the wavy \\
\hline $10-20$ & Wavy to moderately undulating relief \\
\hline $20-47$ & The rugged mountainous relief \\
\hline$>47$ & Mountainous relief \\
\hline
\end{tabular}

Source: EMPRAPA (1999).

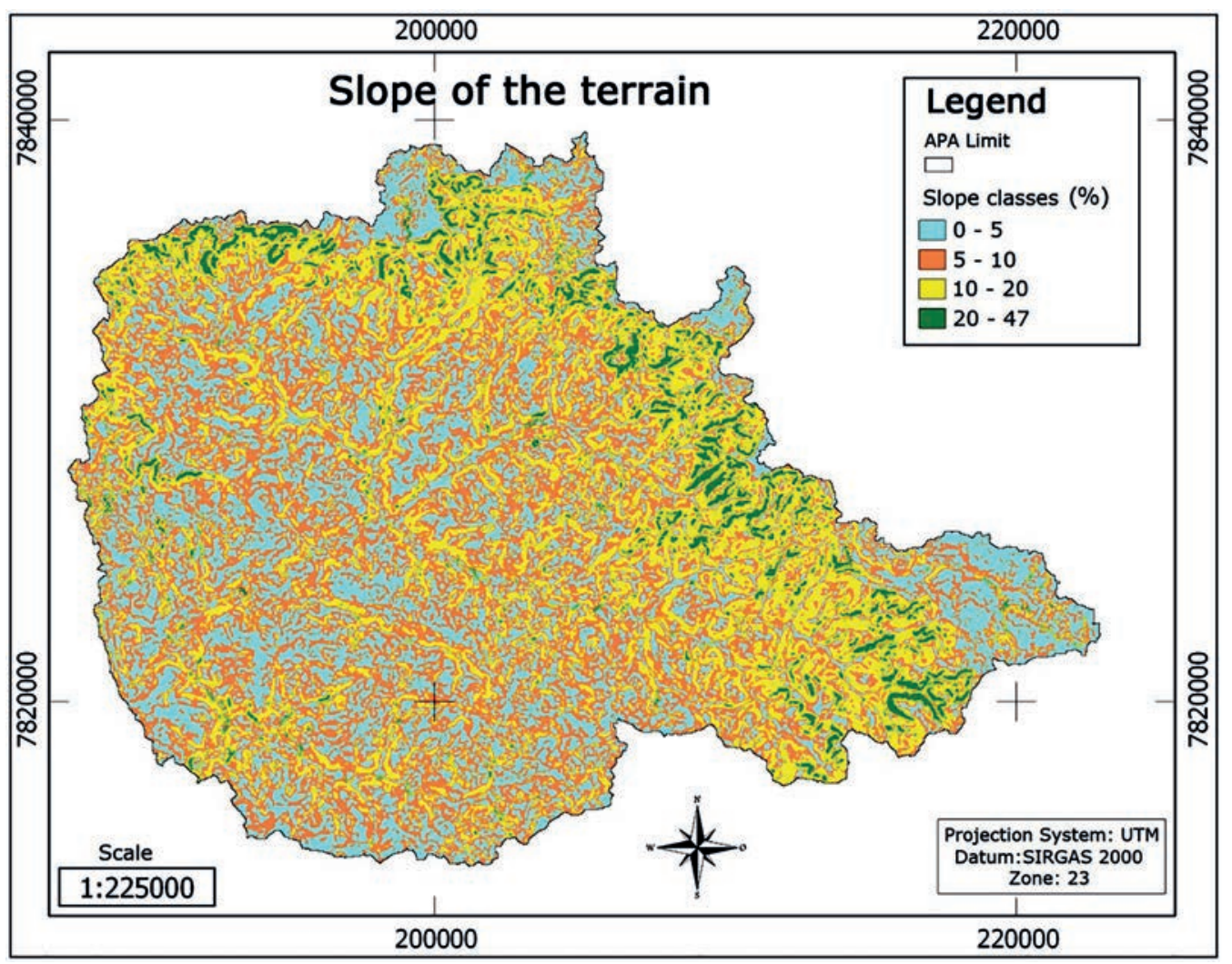

Figure 6 - Map of declivity of the APA of Uberaba River.

The map of soil use and occupation (Figure 7) has been developed using the supervised classific ation with use of the tool "Maxlike" of the GIS were used images from the Land sat 8 sa tellite Sensor "OLI-TIR" collected by the geological survey of the United Sta tes dated 06 February 2014, with spectral resolution of 30 metres. Were used for the colour composition bands 4 (R), 3 $(G)$ and 2 (B) in which these scenes were cut individually in GIS. Following devised the Landsat 8 RG B composition with the use of "Composite" tool. Were classified as to the use of the soil the following vegetable toppings: pasture, forests and annual crops.

The map of soil classes was generated from the cut in the soil of the State of Minas Gera is provided by UFV et al. (2010), illustrated in Figure 8. 


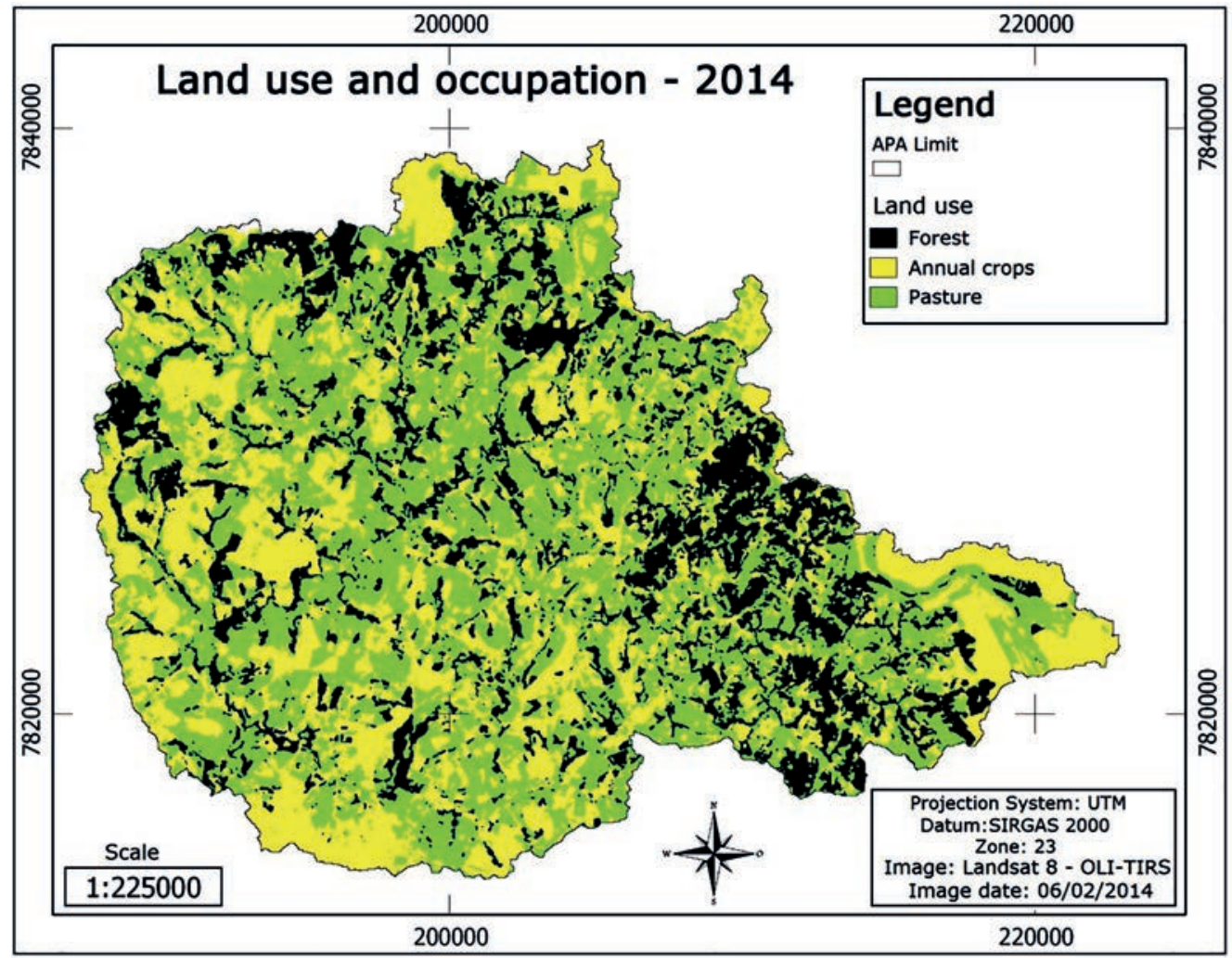

Figure 7 - Map of soil use and occupation of the APA of Uberaba River (2014).

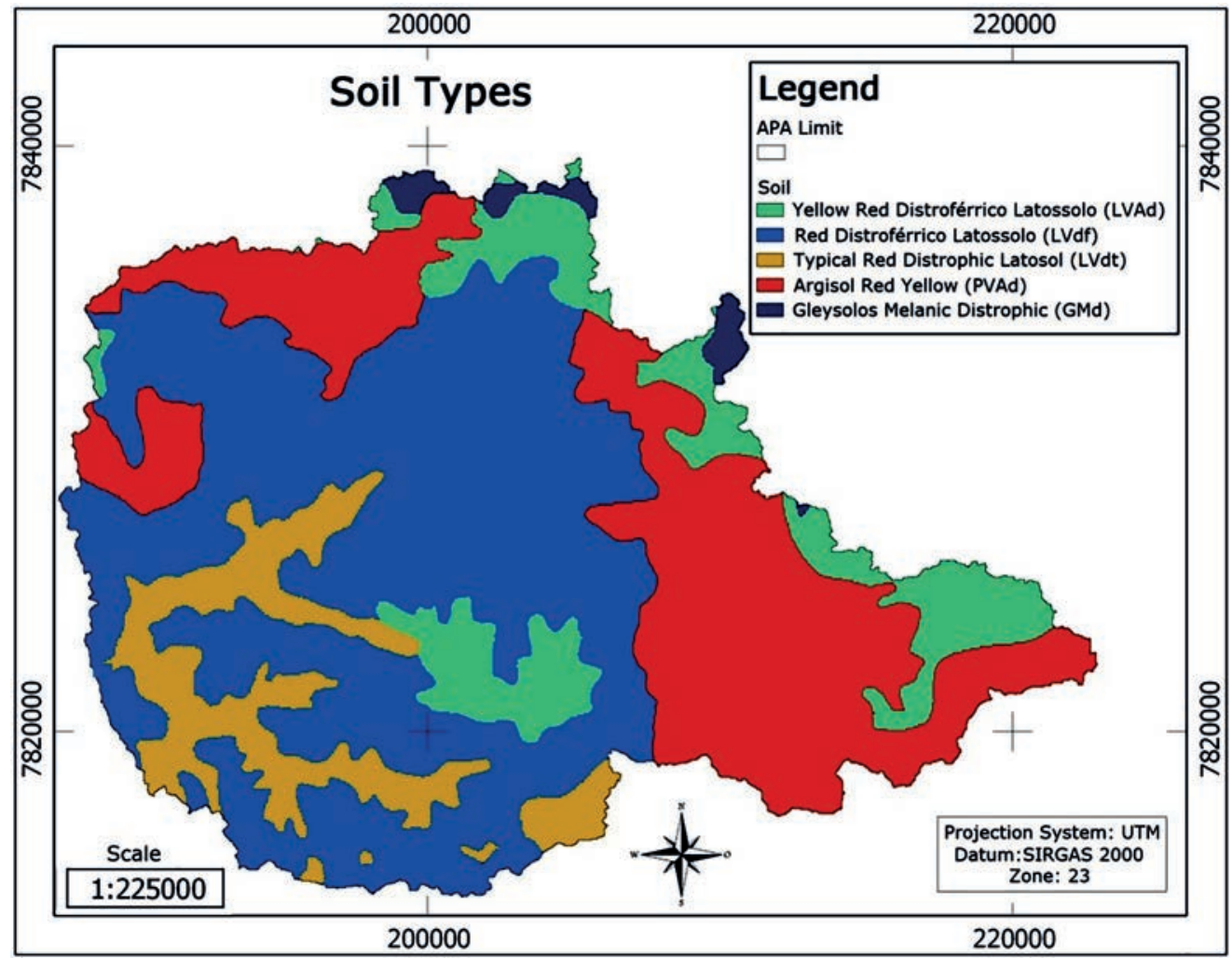

Figure 8 - Map of soil classes of APA of Uberaba River. 
The maps generated in this study a dop ts the system of Universal Tra nsverse Mercator projection (UTM); 23 zone; Datum horizontal a lignment 2000 SIRG AS (Geocentric Reference System for the Americas).

\section{Standardization}

The sta ndardization of the criteria analyzed followed a byte-level range ( 0 to 255), assigning the level 0 less importance and 255 greater importance. The construction of decision rule was executed by means of the functions of relevance to the whole "fuzzy". The slope, dra ina ge density, distance of water courses, classes of soil and the use and occupation of the soil were analyzed as continuous maps in "raster" format.

\section{Sensory analysis and assignment of weights}

Possession of the structured criteria in database in GIS, sensory a nalysis of these c riteria, which consisted of bibliographic surveys and discussions with multid isc ip lina ry tea $m$ about the importance of each factor in the process of vulnerability of water resources. Sought in the disc ussions with the various forms of interpretation and of valuesassignments and importance in the different criteria used in these studies (Table 2).

Importance values used in this study was also observed in research developed by Abbaspour et al. (2011), Pinto (2010) and
Valle J unior (2014) rela ted to environmental vulnera bility.

Depending on the use of several factors for surface a na lysis of wa ter reso urces vulnerability and whereas these have different weights in the decision-making process was established the routine WEIG HT (“Weighted Linear Combination"-WLC) from IrisDRISI, a weighting of va riables, according to your degree of relative importance on the decision. Through a paired comparison technique, developed by Sa aty (1980), in the context of a decision-making process known as a na lytic hiera rc hy process (AHP), which consists of the categorization problem in linear hiera rchical levels of importance in relation to each environmental factor (Table 3 ).

Based on the scale of comparators in Id risi were adopted 3 (three) different weighting factors scenarios by assigning greaterimportance to the criterion value of slope of the land (scenario 1), drainage density (scenario 2) and soil class 3 scenario (Table 4). This procedure was used to compare and id entify, after the assignment of weights in different scenarios, which c riteria indic a tes the a reas of vulnerability of water resources.

The routine of the MCE of Id risi, once assigned importance values, determined the sta tistic al weights for each factor (Table 4) and calculated the consistency index.Indicates the probability of the consistency of the points a rray to be generated at random and shall be less than 0.1 for model be considered accepTable (EASTMAN, 2012). 
Table 2 - Criteria identified for the study of environmental vulnerability.

\begin{tabular}{|c|c|c|}
\hline Criteria (factors) & Assigned & Values \\
\hline \multirow{5}{*}{ Drainage density $\left(\mathrm{Km} / \mathrm{Km}^{2}\right)$} & Too Low & 5 \\
\hline & Low & 25 \\
\hline & Media & 75 \\
\hline & High & 125 \\
\hline & Too high & 255 \\
\hline \multirow{5}{*}{ Away from the water lines (m) } & Distance $(30 \mathrm{~m})$ & 255 \\
\hline & Distance $(50 \mathrm{~m})$ & 175 \\
\hline & Distance (100 m) & 115 \\
\hline & Distance (150 m) & 75 \\
\hline & Distance (200 m) & 50 \\
\hline \multirow{5}{*}{ Slope of the land (\%) } & Slope (0 to $5 \%$ ) & 25 \\
\hline & Slope (5 to $10 \%$ ) & 75 \\
\hline & Slope (10 to $20 \%$ ) & 125 \\
\hline & Slope (20 to $47 \%$ ) & 175 \\
\hline & Slope $(47 \%)>$ & 255 \\
\hline \multirow{3}{*}{ Soil class } & $\begin{array}{l}\text { The presence of } \\
\text { microaggregates }\end{array}$ & 100 \\
\hline & Argissolos & 200 \\
\hline & Gleyssolos & 255 \\
\hline \multirow{3}{*}{ Soil use and occupation } & Forest Fragments & 255 \\
\hline & Pasture & 125 \\
\hline & Annual Crops & 75 \\
\hline
\end{tabular}

Table 3 - Scale of comparators with the respective weights of importance - fundamental Scale Saaty (1980).

\begin{tabular}{cc}
\hline Values & Mutual importance \\
\hline $1 / 9$ & Extremely less important than \\
\hline $1 / 7$ & Very strongly less important than \\
\hline $1 / 5$ & Strongly less important than \\
\hline $1 / 3$ & Moderately less important than \\
\hline 1 & Equally important to \\
\hline 3 & Moderately less important than \\
\hline 5 & Strongly more important than \\
\hline 7 & Very strongly more important than \\
\hline 9 & Extremely important that \\
\hline
\end{tabular}

Source: Saaty (1980). 
Table 4 - Paired comparison matrix which is part of the analytic hierarchy process-AHP (SAATY, 1980).

\begin{tabular}{lcccccc}
\hline & $\begin{array}{c}\text { Distance from } \\
\text { watercourses }\end{array}$ & $\begin{array}{c}\text { Use of } \\
\text { soil }\end{array}$ & $\begin{array}{c}\text { Soil } \\
\text { class }\end{array}$ & $\begin{array}{c}\text { Slope of } \\
\text { the land }\end{array}$ & $\begin{array}{c}\text { Drainage } \\
\text { density }\end{array}$ & Weight \\
\hline $\begin{array}{l}\text { Distance from } \\
\text { watercourses }\end{array}$ & 1 & $1 / 3$ & $1 / 5$ & 1 & 1 & 0.0863 \\
\hline Use of soil & 3 & 1 & $1 / 3$ & $1 / 5$ & 1 & 0.2702 \\
\hline Soil class & 5 & 3 & 1 & $1 / 3$ & $1 / 5$ & 0.4658 \\
\hline Slope of the land & 1 & $1 / 3$ & $1 / 5$ & 1 & $1 / 3$ & 0.0863 \\
\hline Drainage density & 1 & $1 / 5$ & $1 / 3$ & 1 & 1 & 0.0913 \\
\hline
\end{tabular}

The AHP was implemented by the module of weight of the IDRISI J unglesoftware. To this set of factors, the consistency index calculated was 0.07 in sc enario 1 , 0.07 in scenario 2 and 0.04 in scenario 3 considered acceptable for all scenarios adopted.

\section{Aggregation}

The data were aggregated on weighted linear combination (WLC) ("Weighted Linear Combination") of the Idrisi, considering their respective weights resulting in a map from 0 to 255 . It was nec essa ry to combine the data, in order to achieve the General map of vulnerability. In thiscase, a weighted linear combination was used, which combined the criteria and restriction maps according to the following formula:

$$
S j=(\Sigma W i X i) \Pi(C k)
$$

Eq. 2

Where:

Sj: $\quad$ represents the risk to pixel j;

Wi: represents the weight of the factori;

Xi: represents the criterion score of factori;

Ck: represents the constra int criteria score kand;

$\Pi: \quad$ is the symbol of the product.

The factors were combined in applying weights following a dequacy calculated from the product factors to the restric tions. The map was reclassified (Table 5) in five c lasses of vulnera bility of wa ter reso urces: Invulnerable, Modera tely Vulnerable, Vulnerable, Heavily Vulnerable and extremely vulnerable and their respective a rea s were spatialized and calculated. 
Table 5 - Range defined for classifying degree of vulnerability.

\begin{tabular}{lc}
\hline \multicolumn{1}{c}{ Risk classes } & Range of Classes \\
\hline Invulnerable & $0-50$ \\
\hline Moderately Vulnerable & $50-100$ \\
\hline Vulnerable & $100-150$ \\
\hline Heavily Vulnerable & $150-200$ \\
\hline Extremely Vulnerable & $200-255$ \\
\hline
\end{tabular}

Results and

Discussion

\section{Sensitivities of} the factors and

assignment of

\section{weights}

The importance of soil class, fator weights were the 0.0863 (distance of watercourses), 0.2702 (soil use and occupation), 0.4658 (soil class), 0.0863 (slope of the land) and 0.0913 for dra ina ge density; being the relationship of consistency of $4 \%$. However, for similar weights for the same sc enario 3 noted that the consistency index was the sa meobtained by (VALLE J UNIOR et al. 2014). In this manner, appending the drainage density factor the consistency index remained the same.

\section{The vulnerability in the APA}

The map of vulnerability of water resources based on weighted linear combination (Eq . 2) of the factors referred to above is illustrated in Figure 9, with the values of the vulnerability described in the Table 6 . The results of the vulnerability represent am the high potential risk of contamination of water resources therefore strongly c lasses and extremely vulnerable occupy a portion of (16.39\%, $7.12 \%)$ of the APA and the vulnerable class (49.89\%) total $73.4 \%$. The most plausible cause for this fact is the occupation of the areas G leysolos, Argissolos and the presence of Mic roaggregates coupled with land use factor tha twerec la ssified with a very high note until 255 byte. 


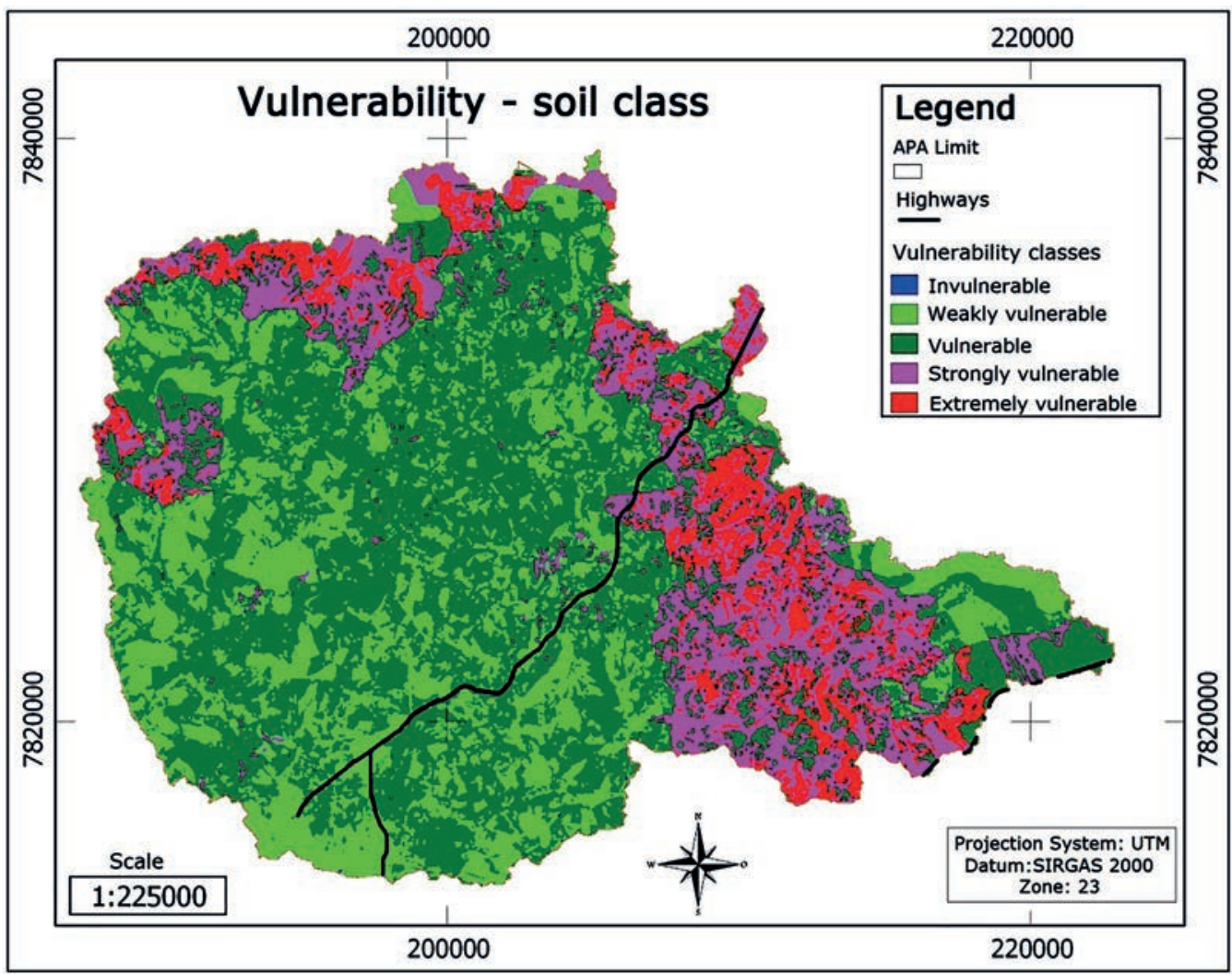

Figure 9 - Map of vulnerability of water resources in APA of Uberaba River.

Table 6 - Areas of vulnerability in the APA of Uberaba River.

\begin{tabular}{lcc}
\hline \multicolumn{1}{c}{ Risk classes } & Area $\left(\mathbf{k m}^{\mathbf{2}}\right)$ & Percentage of area (\%) \\
\hline Invulnerable & 0.00 & 0 \\
\hline Moderately Vulnerable & 138.438 & 26.6 \\
\hline Vulnerable & 259.690 & 49.9 \\
\hline Heavily Vulnerable & 85.340 & 16.4 \\
\hline Extremely Vulnerable & 37.061 & 7.1 \\
\hline Total & $\mathbf{5 2 0 , 5 2 9}$ & $\mathbf{1 0 0}$ \\
\hline
\end{tabular}

With this study it was possible to determine in the APA of Uberaba River the vulnera bility enviro nmental. According to morphometric and physical parameters of the catchment a rea and with the use of the Geographical information system it was possible to evaluate jointly the different levels of information.

Because it is a conservation a re a the area of Environmental protection, whose activities must be susta inable and use their water resources (ma in course of 
the Uberaba River) bein the supplying the population of Uberaba, thereis a need for studies that seek to assess the environmental quality of the existing natural resources as well as propose measures of preservation and conservation.

Environmental vulnera bility occ urs in the area studied, which indicates the risk of degradation of the na tural environment, related to soil erosion, loss of biodiversity, contamination of soil and water resources and vegetation cover loss aggravated by roads and misuse of the soil.

The dominant factor in the transport of contaminants to the water courses is the runoff, being the same powered by declivities, uses presented soil and physical characteristic s of the same. In this way the classes of soils prone to shallow streams generation given its characteristics, the

\section{References}

ABBASPOUR, M., MAHIN, A.S., ARJMANDY, R. and NAIMI, B., 2011. Integrated approach for land use suitability analysis. International Agrophysics, vol. 25, pp. 311-318. Available in: <http://www. old.internationalagrophysics.org/en/issues. html?stan=detail\&vol=25\&numer=4\&paper=946\&i=1 . Access: july 2014.

ABDALA, V.L., 2012. Diagnóstico hídrico do rio Uberaba - MG como subsídio para a gestão das áreas de conflito ambiental. 2012. 64 f. Tese (Doutorado em Agronomia) - Faculdade de Ciências Agrárias e Veterinárias, Universidade Estadual Paulista "Júlio de Mesquita Filho", Jaboticabal.

AKINCI, H., ÖZALP, A.Y. and TURGUT, B., 2012. Agricultural land use suitability analysis using GIS and AHP technique. Computers and Electronics in Agriculture, vol. 97, pp. 71-82. http://dx.doi. org/10.1016/j.compag.2013.07.006. topography, the distance of the courses of the rivers interfluvial (drainage density and uses data to soils) should be strongly considered as elements of decision making for the management of water resources of this area, in order to promote the ma intenance of them quantita tively and qua lita tively.

\section{Conclusion}

The use of multi-c riteria a nalysis applied to the study of vulnerability of water resourcescan be employed in several studies since there is a correlation to the factors involved.

Morphometric and physic al aspects of influence in basin environmental vulnera bility.

BANAI, R., 1993. Fuzziness in Geographical Information Systems: Contribution from the Analytic Hierarchy Process. International Journal of Geographical Information Science, vol. 7, no. 4, pp. 315-329. http://dx.doi.org/10.1080/02693799308901964.

BRASIL, 2000. Lei no 9.985 de 18 de julho de 2000. Regulamenta o art. 225, § 10, incisos I, II, III e VII da Constituição Federal, institui o Sistema Nacional de Unidades de Conservação da Natureza e dá outras providências. Brasília, DF. Available in: http://www. planalto.gov.br/ccivil_03/LEIS/L9985.htm. Access: Oct. 2014.

BRASIL, 2007. Ministério do Meio Ambiente. Vulnerabilidade Ambiental. Brasilia, $192 \mathrm{p}$.

BOTTERO, M., COMINO, E., DURIAVIG, M., FERRETTI, V. and POMARICO, S., 2013. The application of a Multicriteria Spatial Decision Support System (MCSDSS) for the assessment of biodiversity conservation in the Province of Varese (Italy). Land Use Policy, vol. 30, pp. 730-738. http://dx.doi.org/10.1016/j. landusepol.2012.05.015. 
CALIZAYA, A., MEIXNER, O., BENGTSSON, L. and BERNDTSSON, R., 2010. Multi-criteria Decision Analysis (MCDA) for Integrated Water Resources Management (IWRM) in the Lake Poopo Basin, Bolivia. Water Resources Management, vol. 24, pp. 2267-2289. http://dx.doi.org/10.1007/s11269009-9551-x.

CARDOSO, C.A., DIAS, H.C.T., SOARES, C.P.B. and MARTINS, S.V., 2006. Caracterização morfométrica da bacia hidrográfica do rio Debossan, Nova Friburgo, RJ. Revista Árvore, vol. 30, no. 2, Viçosa.

CHEN, Y. and PAYDAR, Z., 2012. Evaluation of potential irrigation expansion using a spatial fuzzy multi-criteria decision framework. Environmental Modelling \& Software, vol. 38, pp. 147-157. http://dx.doi. org/10.1016/j.envsoft.2012.05.010.

CHRISTOFOLETT, A., 1969. Análise morfométrica de bacias hidrográficas. Notícia Geomorfológica, vol. 18, no. 9, pp. 35-64.

CHISTOFOLETTI, A., 1980. Geomorfologia. São Paulo: Edgard Blüchler. 2 ed. 149p.

CRUZ, L.B.S., 2003. Diagnóstico ambiental da bacia hidrográfica do rio Uberaba - MG. 2003. 182 f. Tese (Doutorado em Engenharia Agrícola)- Faculdade de Engenharia Agrícola, Universidade Estadual de Campinas, Campinas.

DRAGINCIC, J., KORACB, N. and BLAGOJEVICA, B., 2015. Group multi-criteria decision making (GMCDM) approach for selecting the most suitable table grape variety intended for organic viticulture. Computers and Electronics in Agriculture, vol. 111, pp. 194-202. http://dx.doi.org/10.1016/j.compag.2014.12.023.

EMBRAPA, 1999. Empresa Brasileira de Pesquisa Agropecuária. Centro Nacional de Pesquisa de Solos. Sistema brasileiro de classificação de solos. Rio de Janeiro, 412 p.

EMBRAPA, 2006. Empresa Brasileira de Pesquisa Agropecuária. Centro Nacional de Pesquisa de Solos. Sistema Brasileiro de Classificação de solos. Rio de Janeiro, 2 ed., 306 p.

EASTMAN, J.R., 1998. IDRISI para Windows. Introdução aos exercícios tutoriais. Versão 2. Tradução: Heinrich Hasenack e Eliseu Weber. Porto Alegre, UFRGS Centro de Recursos IDRISI.

EASTMAN, J.R., 2012. IDRISI Selva Manual. Worcester, MA: Clark Labs, Clark University. 322 f. Available in: http://clarklabs.org/products/spanish-manual.cfm. Access: Jan. 2014.
FERREIRA, C.E.G., 2012. Sistema de Suporte à decisão espacial aplicado à análise da vulnerabilidade dos recursos hídricos na bacia Guapi-Macacu - RJ. 152 f. Dissertação (Mestrado em Engenharia de Computação) - Faculdade deEngenharia, Universidade do Estado do Rio de Janeiro, Rio de Janeiro.

GARFI, M., FERRER-MARTÍ, L., BONOLI, A. and TONDELLI, S., 2011. Multi-criteria analysis for improving strategic environmental assessment of water programmes.A case study in semi-arid region of Brazil, Journal of Environmental Management, vol. 92, pp. 665-675. http://dx.doi.org/10.1016/j. jenvman.2010.10.007.

HORTON, R., 1945. Erosional development of streams and their drainage basins: hidrophysical approach to quatitative morphology. Geological Society of American Bulletin. New York, vol. 56. pp. 807-813.

IBGE, 1974. Instituto Brasileiro de Geografia e Estatística. Cartas Topográficas. Folha SE 23-Y-C-IV (Uberaba). Brasília: IBGE. (Escala: 1:100.000). Available in: http://www.ibge.gov.br. Access: Jun. 2014.

JIANG, H. and EASTMAN, J.R., 2000. Application of fuzzy measures in multi-criteria evaluation in GIS, International Journal of Geographical Information Systems, vol. 14, no. 2, pp. 173-184. http://dx.doi. org/10.1080/136588100240903.

KAYA, T. and KAHRAMAN, C., 2011. Fuzzy multiple criteria forestry decision making based on an integrated VIKOR and AHP approach. Expert Systems with Applications, vol. 38, no. 6, pp. 7326-7333. http:// dx.doi.org/10.1016/j.eswa.2010.12.003.

LEPSCH, I.F., 2002. Formação e conservação dos solos. São Paulo: Oficina de Textos.

LIMA, W.P., 1986. Princípios de hidrologia florestal para o manejo de bacias hidrográficas. São Paulo: ESALQ, 242 p.

LIMA, L.A., SILVA JR., G.C., MENEZES, J.M. and SEABRA, V.S., 2009. Favorabilidade de Aqüíferos Fraturados, Bacia Hidrográfica do Rio São Domingos Estado do Rio de Janeiro. Anuário do Instituto de Geociências, vol. 32, no. 2. Rio de Janeiro: UFRJ, pp. 51-61. Available in: http://www.anuario.igeo.ufrj. br/2009_2/anuario_2009_v32_2_sumario.htm>. Access: July 2015.

MACHARIS, C., TURCKSIN, L. and LEBEAU, K., 2012. Multi actor multi criteria analysis (MAMCA) as a tool to support sustainable decisions: State of use. Decision Support Systems, vol. 54, pp. 610-620. http://dx.doi.org/10.1016/j.dss.2012.08.008. 
MALCZEWSKI, J., 1999. GIS and Multicriteria Decision Analysis, John Wiley and Sons. New York, p. 392. Available in: <http://books.google.pt/books?id=2Zd54x 4_2Z8C\&printsec=frontcover\&source=gbs_ge_

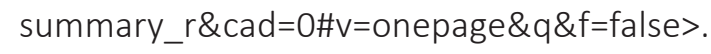

MARTIN-ORTEGA, J. and BERBEL, J., 2010. Using multi-criteria analysis to explore non-market monetary values of water quality changes in the context of the Water Framework Directive. Science of the Total Environment, vol. 408, no. 19, pp. 3990-3997. http://dx.doi.org/10.1016/j.scitotenv.2010.03.048.

MOTTA, L.H.S.O. and VALLADARES, G.S., 2011. Vulnerabilidade à degradação dos solos da Bacia do Acaraú, Ceará. Revista Ciência Agronômica, vol. 42, no. 1, pp. 39-50. Available in: <http://www. ccarevista.ufc.br/seer/index.php/ccarevista/article/ view/1041/533.

MUSA, K.A., AKHIR, J.M. and ABDULLAH, I., 2008. Groundwater Prediction Potential Zone in Langat Basin using the Integration of Remote Sensing and GIS.In: XVI Congresso Brasileiro de Águas Subterrâneas e XVII Encontro Nacional de Perfuradores de Poços. Anais... Natal: ABAS.

NISHIYAMA, L., 1989. Geologia do Município de Uberlândia e áreas adjacentes. Sociedade e Natureza, Uberlândia, vol. 1, no. 1, pp. 9-15.

NISHIYAMA, L., 1998. Procedimentos de mapeamento geotécnico como base paraanálises e avaliações ambientais do meio físico, em escala 1:100.000: aplicação no município de Uberlândia - MG. Tese (Doutorado em Geotecnia) - Universidade Federal de São Carlos, São Paulo.

OLIVEIRA, J.B., 2005. Pedologia aplicada. 2. ed. Piracicaba: FEALQ, $574 \mathrm{p}$.

PRADO, R. B., 2004. Geotecnologias aplicadas à análise espaço-temporal do uso e cobertura da terra e qualidade da água de Barra Bonita, SP, como suporte à gestão de recursos hídricos. $172 \mathrm{f}$. Tese (Doutorado em ciências das Engenharia Ambiental). Universidade de São Paulo, São Carlos, 2004. Available in: <http://www.teses.usp.br>. Access: Oct. 2014.

PINTO, R.C., 2010. Verificação de aptidão de áreas selecionadas para instalação de parque de lazer no Município de Paranaguá-PR utilizando-se de sistemas de informações geográficas. Geoingá: Revista do Programa de Pós-Graduação em Geografia, vol. 2, no. 1, pp. 83-104. Available in: http://periodicos.uem. br/ojs/index.php/Geoinga/article/view/14964/8398. Access: Jul. 2014.
PISSARRA, T.C.T., 2002. Análise da Bacia Hidrográfica do Córrego Rico na sub-região de Jaboticabal, SP: Comparação entre imagens TM-LANDSAT 5 e Fotografias aéreas verticais. $136 \mathrm{f}$. Tese (Doutorado em Produção Vegetal) Faculdade deCiências Agrárias e Veterinárias, Universidade Estadual Paulista, Jaboticabal.

PISSARRA, T.C.T., POLITANO, W. and FERRAUDO, A.S.. 2004. Avaliação de características morfométricas na relação solo-superfície da bacia hidrográfica do córrego Rico, Jaboticabal (SP). Revista Brasileira de Ciência do Solo, vol. 28, pp. 297-305. http://dx.doi. org/10.1590/S0100-06832004000200008.

ROCHA, J.S.M., 1977. Avaliação quantitativa da capacidade de uso da terra do estado do Rio Grande do Sul. 169 f. Tese (Livre Docência) - Universidade Federal deSanta Maria, Santa Maria.

ROCHA, J.S.M., 1997. Manual de projetos ambientais. Santa Maria: UFSM. 423p.

SAATY, T.L., 1980. The Analytic Hierarchy Process. Planning, Priority Setting, Resource Allocation. McGraw-HillUSA.

SANTOS, A.F., 2004. Morfometria da microbacia hidrográfica do Ribeirão Faxinal Botucatu - SP e alterações em suas áreas de biomassa no período de 1972 a 2000. 59 f. Dissertação (Mestrado em Agronomia)- Faculdade de Ciências Agronômicas, Universidade Estadual Paulista "Júlio de Mesquita Filho", Botucatu.

SENER, E., DAVRAZ, A. and OZCELIK, M. An Integration of GIS and remote sensing ingroundwater investigations: A case study in Burdur, Turkey. Hydrogeology Journal, p. 826-834. Available in: http:// www.springerlink.com/content/c3ha1w4225f91qrj. Access: Jan. 2015.

SOUZA, A.L.N., FERNANDES, V.H., CARVALHO, L.G. and ANTUNES, M.A.H., 2003. Ferramentas de geoprocessamento para estudos de potencial hidrogeológico. In: XXI Congresso Brasileiro de Cartografia, SBC, Belo Horizonte. Anais... Belo Horizonte.

SOUZA, T.A.R., HISSA, L.B.V., MICHEL, R.F.M. and MORAIS A.M.L., 2009. Análise de Multicritério aplicada ao diagnóstico do risco ambiental do transporte rodoviário de produtos perigosos: um estudo de caso sobre a BR-381. In: XIV Simpósio Brasileiro de Sensoriamento Remoto, 2009, Natal. Anais eletrônicos... INPE. Natal, RN. Available in: http://marte. sid.inpe.br/col/dpi.inpe.br/sbsr@80/2008/11.18.01.02/ doc/4465-4472.pdf. Access: Jun. 2015. 
UFV, 2010. Universidade Federal de Viçosa. Fundação Centro Tecnológico de Minas Gerais; Universidade Federal de Lavras; Fundação Estadual do Meio Ambiente. Mapa de solos do Estado de Minas Gerais. Belo Horizonte. p. 35-49.

VALLE JUNIOR, R.F., 2008. Diagnóstico de áreas de risco de erosão e conflito de uso dos solos na bacia do rio Uberaba. 222 f. Tese (Doutorado em Agronomia) - Faculdade de Ciências Agrárias e Veterinárias, Universidade Estadual Paulista "Júlio de Mesquita Filho", Jaboticabal.

VALLE JUNIOR, R.F., GALBIATTI, J.A., MARTINS FILHO, M.V. and PISSARRA, T.C.T., 2010. Potencial de erosão da bacia do Rio Uberaba. Engenharia Agrícola, vol. 30, pp. 897-908. http://dx.doi.org/10.1590/s010069162010000500012.

VALLE JUNIOR, R.F., VARANDAS, S.G.P., SANCHES FERNANDES, L.F. and PACHECO, F.A.L., 2014. Environmental land use conflicts: a threat to soil conservation. Land Use Policy, vol. 41, pp. 172-185. http://dx.doi.org/10.1016/j.landusepol.2014.05.012.

VALLE JUNIOR, R.F., VARANDAS, S.G.P., SANCHES FERNANDES, L.F. and PACHECO, F.A.L. Multi Criteria Analysis for the monitoring of aquifer vulnerability: A scientific tool in environmental policy. Environmental Science \& Policy, vol. 48, pp. 250-264. http://dx.doi. org/10.1016/j.envsci.2015.01.010.
VELDKAMP, A. and LAMBIN, E.F., 2001. Predicting landuse change, Agriculture, Ecosystems \& Environment, vol. 85, pp. 1-6. http://dx.doi.org/10.1016/S01678809(01)00199-2.

VIEIRA, C.A.O., 2000. Accuracy of remotely sensing classification of agricultural crops: a comparative study. P. 327. Thesis (Doctor of Philosophy in Physical Geography)- University of Nottingham, Nottingham.

VILLELA, S.M. and MATTOS, A., 1975. Hidrologia aplicada. São Paulo: McGraw-Hill do Brasil. 245 p.

YU, J., CHEN, Y. and WU, J.P., 2009. Cellular Automata and GIS based landuse suitability simulation for irrigated agriculture. In: 18th World IMACS/MODSIM Congress, Cairns, Australia, p. 7. http://metronu.ulb. ac.be/imacs/cairns/18/yu_j.pdf.

ZADEH L.A., 1965. Fuzzy sets. Inf. Control, vol. 8, pp. 338-353.Available in: http://www.cs.berkeley. edu/ zadeh/papers/Fuzzy\%20SetsInformation\%20 and\%20Control-1965.pdf.

ZHANG, J., WANG, K., CHEN, X. and ZHU, W., 2011. Combining a Fuzzy Matter-Element Model with a Geographic Information System in Eco-Environmental Sensitivity and Distribution of Land Use Planning. Int. J. Environ. Res. Public Health, vol. 8, pp. 12061221. http://dx.doi.org/10.3390/ijerph8041206. 


\section{World Bank Model Calibration Project with SWAT Methodology in 0chomogo River, Nicaragua (1st Stage)}

Cordero, M.', García, A. ', Lacayo, N.' ', Ramos, J.' ', Yescas, L. ', Peña, E. ', Laver, W. ${ }^{2}$, Archibald, J. ${ }^{2}$

'Faculty of Science, Technology and Environment, Universidad Centroamericana, Managua, Nicaragua.

${ }^{2}$ College of Science and Engineering, Seattle University, Seattle, USA.

Corresponding author: mariajose.corfer@gmail.com, anasvet.28@gmail.com, normanenriquelacayocuadra@gmail.com, josephramosfuentes@gmail.com, luisyeskas@ gmail.com, elizabetp@uca.edu.ni, laverj@seattleu.edu, archibaj@seattleu.edu

\section{Abstract}

The World Bank's Model Calibration Project with the SWAT Methodology in the Ochomogo River (1st stage) is an investigation that begins as a necessity for generating field data to calibrate the data already presented in the study conducted by the World Bank (2013).Considering the Ochomogo River as an important tributary for the Cocibolca Lake, the World Bank by using SWAT modeling calculated an estimation of the incoming volume of sediments that enter to the lake, in order to identify the principal pressure exerted on the river by the diverse human activities taking place in the sub-basins than discharge into the lake. This investigation consisted generating the data for tracing calibration curves used for the analysis of the watershed behavior. Besides obtaining data from the sensors, installed by the investigation team in alliance with Seattle University, used for monitoring the levels of the river in real time and the flow measurements made weekly, currently there are also installed two rain gauges which recordings match the historical data of precipitation for that area. In order to improve the credibility of the data, it's recommended to continue the monitoring, especially the data obtained about the correlation between the led sensor recordings 
and the quantity of total suspended solids. The principal goal expected to achieve in the following stages is to apply the SWATmodeling with the information that'll be generated to the basin and being able to calibrate it and improve it with time.

Keywords: hydrographic basin, hydrological monitoring, flow, lake, sedimentation, modeling validation.

\section{Introduction}

The Lake Cocibolca Watershed located in Nicaragua is an important freshwater resource for the country, and its value transcends all of Central Americ a. Currently, this resource is being used as water supply for some cities and its use may increase in the future. Being second largest lake in Latin America and the watershed's location within the Mesoamerican Biological Corridor has made it a meeting ground for fish, bird and mammal species from North and South America.

The Lake Cocibolca and its watershed are under pressure from multiple sources that threaten its ecological balance, as the sediment and nutrient load coming from the sub-basins that compound it; given the few information available and lack of monitoring over time, the degree of environmental degradation is unc lear. In this context, the Intemational Bank for Reconstruction and Development (The World Bank) carried out a study in 2013 where they evaluated the sources and the magnitude of these pressures that threa ten the Lake, through the applic ation of a hydrological and land use model SWAT (Soil and Water Assessment Tool). The study was developed to obta in an approximation about the volume of sediments a nd nutrients that a rrive a nnua lly to the lake.

In this study the Ochomogo River was identified as one of the main sediment contributors, however, this evaluation should be interpreted cautiously because the model has not been calibrated; this is due to the little a vailability of data, which limits the assessment of the severity of environmental problems and their likely of social and economic impacts. Therefore, these measures should be taken as indica tive measures of magnitude instead of precise estimates.

The present investigation begins as a need to analyze the estima tes presented in the study conducted by the World Bank. And it covers from the a nalysis of a vailable information, such as maps of current land use, topographic sheets and meteorological information, to the a nalysis of information generated in the field. To obtain field data it was necessary the installation of equipment in the Ochomogo river, in the lower part of the basin. This equipment has sensors that allow monitoring in real time, a tmospheric pressure, hydrostatic pressure, temperature, suspended solids (measured by turbidity) and precipitation.

This investigation offers the possibility of generating information that is extremely useful for the beginning of future research. The data obtained have the purpose of 
contributing to the development of the communities; in this case, the intention is make flood maps, identification of risk a reas through the a nalysis of the hyd rological characteristic s of the basin and the hydraulic s of the main channel.

The analysis of the data obtained leads to the calibration of the model in one of the basins that contributes the largest volumes of sediment to the lake according to the World Bank report, such as the Ochomogo River. The information obtained to date has allowed generating calibration curves for the a nalysis of the behavior of the basin. Likewise, in order to verify the veracity of the data comparisons were made of the rainfall data from the meteorological sta tions of the Nic ara guan Institute of Territorial Studies (INETER) and the one obtained by the sensors installed by the research team, compound by Universidad Centroameric ana and Seattle University professors and Students.

The main a im of the present study was to analyze the results of meteorological and hydraulic data obtained in the first stage of the World Bank Model Calibration Project with the SWAT methodology in the Ochomogo River located in the department of Granada, Nicaragua.

\section{Methodology}

\section{Placement of instruments}

The study was performed in the Ochomogo river basin, delimited with the SWAT tool and validated through the Nicaragua Basins Guide under the Pfafstetter methodology developed by the Nic araguan Institute of Territorial Studies (2014). The insta lla tion of equipment fordata collection, based on the methodology of the study of Wagner, Boulger, Oblinger, \& Smith (2006). This consisted of the placement of two rain gauges with information storage systems at distant points within the watershed and the location of topographic sights and an electronic circuit in the lower part of the watershed on the riverside. The circ uit was constituted by a pressure transducer, a turbidity sensor, a temperature and atmospheric pressure meter, programmed through an arduino and coupled with a mini GSM module, this allows the transmission of the values obta ined in 15 minutes intervals, by satellite signal to a web page corresponding to a public data collection site called ThinkSpeak.

A series of a rea reconna issance visits were carried out, in order to select the most appropriate place to obtain real data, considering the lowest a nthropogenic incidence, the security of the installed equipment and the guarantee of the transmission in real time. As well the disposition by the owner of the farm was contemplated due to the need to take note of the river level in the topographic sights twice a day.

The installation of the electronic circuit was made according to the method described by Kelley et al. (2014), it was installed on September 13th, 2016 in the lower part of the basin, near the river, ensuring the submersion of the pressure transducer and the turbidity sensor up to the reference level considered after the placement of topographic sights. 
The Rainwise pluviometers were calibrated to know exactly the number of millimeters of water represented by each registered unit. These were placed on October 17, 2016, one was placed on the farm adjacent to the site of installation of equipment in the river, and the second one waslocated in the middle of the basin, in the urban area of the city of Nandaime.

For the establishment of the correlation between the readings made by the turbidity sensor and the concentration of solids in the water, the dilution of 6 samples with va rio us a mounts of sed iments was c a rried out prior to the installation.

\section{Field measurements}

The compilation of information in situ was carried out through nine visits, after the installation of the equipment, in these we proceeded to make battery changes, ma intenance of the equipment and download of the stored information.

For the determination of the river flow, a current meter was used, through which velocity measurements were obtained in manner of revolutions per minute in a cross section of the river as described by the World Meteorological Organization (2011). This was determined through the vertic al measurements from the starting point, to over the total width, dividing it in sections of 1,5 meters each; considering the relationship of the velocity with the water column of the section, measurements were made at 20 and 60 percent of the total depth to obtain a more truthful average. In view of the flooding of the river, due to safety measures, the method of surface determination by flotation was used.

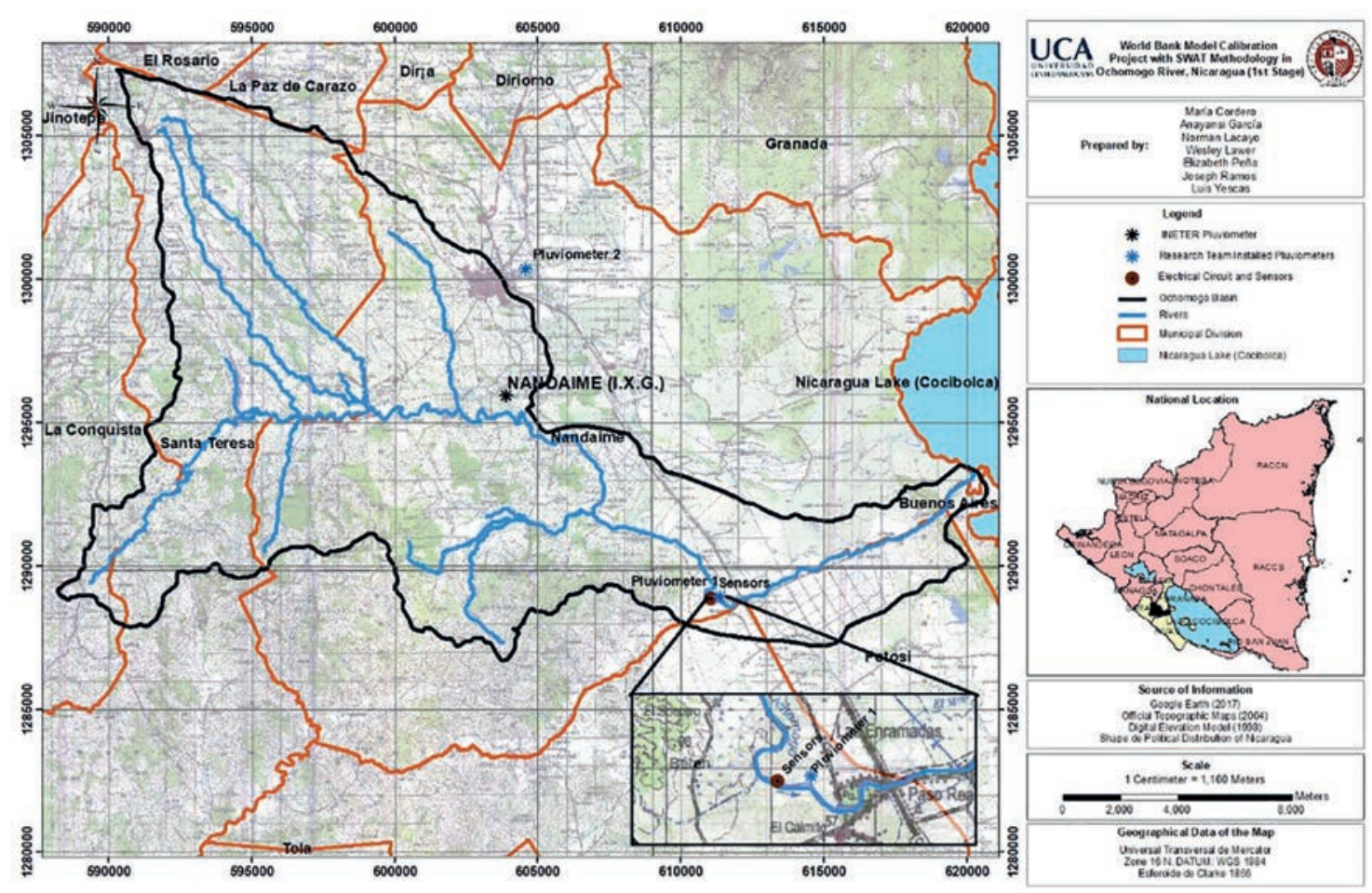

Figure 1 - Map of the Ochomogo sub-basing showing the location of monitoring points. 
The sampling of water was made during the months of September-December 2016, at the same point of the flow measurement, using the collector vessel to perform the immersion to an appropriate depth in an ascending and descending manner, gua ranteeing its tota I filling.

The discharge of the two rain gauge information was differentiated, obtaining va lues from its installation until the midd le of November for the first one and the sec ond until the first 16 days of the month of December.

\section{Determination}

\section{of solids}

\section{concentrations}

The water samples were a nalyzed through the methodologies established by the Standard Methods for the Examination of Water and Wastewater prepared by American Public Health Association (1998), this was carried out for the parameters of total suspended solids, tota I solids and the ir fixed and volatile components. All the prepared dilutions were ma de considering the total volume of the sample, it was only used 10 milliliters for each of the nine samplings made in the field visits.

\section{Information Processing}

The information obtained was compiled and arranged, the existing bibliographic information was considered for structuring the results.

The precipitation values of the two sampled sites were correlated for the analogy of events within the basin. It was compared with the historic al data of the Nica raguan Institute of Territorial Stud ies (INETER) in the Nandaime station of the last 16 years for the only month of complete measurements, corresponding to the month of November.

Consecutively, the transformation of the speed readings to flow was carried out using the current meter equation, followed by the use of the AutoCAD program for the estimate of the cross section's area.

The a na lysis of the turb id ity readings was realized in relation to the total solids concentrations obta ined from the dilutions for the calibration, as well as the analysis of the values and readings of the nine samples.

Considering the flow measurements versus the measured water level, a correspondence equation was determined, at the same time a relationship with the determined hydrostatic pressure values was developed.

\section{First Results \\ Correlation of hydrological monitoring parameters}

The flows determined during the nine measurements made in the Ochomogo River a re shown in Table 1, as well as the water level that was reported at the precise moment of the gauging. 
Table 1 - Resume of the flows with river levels.

\begin{tabular}{ccccccc}
\hline Date & Method & $\begin{array}{c}\text { Effective } \\
\text { area }\left(\mathbf{m}^{2}\right)\end{array}$ & $\begin{array}{c}\text { Average } \\
\text { speed }(\mathbf{m} / \mathbf{s})\end{array}$ & $\begin{array}{c}\text { Flow } \\
\left(\mathbf{m}^{3} / \mathbf{s}\right)\end{array}$ & $\begin{array}{c}\text { Measurement } \\
\text { time }\end{array}$ & $\begin{array}{c}\text { Riverlevel } \\
(\mathbf{x 1 0} \mathbf{~ c m})\end{array}$ \\
\hline $16 / 09 / 26$ & Current meter & 2,67 & 0,364 & 0,97 & $13: 30$ & 2,1 \\
\hline $16 / 01 / 03$ & Current meter & 2,9 & 0,306 & 0,89 & $10: 11$ & 1,6 \\
\hline $16 / 10 / 10$ & Current meter & 3,8 & 0,374 & 1,09 & $10: 50$ & 2,5 \\
\hline $16 / 10 / 17$ & Current meter & 2,36 & 0,377 & 0,86 & $8: 55$ & 1,7 \\
\hline $16 / 10 / 19$ & Floatmethod & 15,95 & 0,680 & 10,85 & $9: 07$ & 7,2 \\
\hline $16 / 10 / 31$ & Current meter & 2,67 & 0,481 & 1,29 & $9: 09$ & 1,7 \\
\hline $16 / 11 / 02$ & Current meter & 21,8 & 0,735 & 16,01 & $16: 49$ & 8,8 \\
\hline $16 / 11 / 11$ & Current meter & 2,75 & 0,500 & 1,38 & $8: 58$ & 1,7 \\
\hline $16 / 11 / 14$ & Current meter & 2,97 & 0,342 & 1,19 & $10: 28$ & 1,7 \\
\hline
\end{tabular}

From the previous table, the following image was extracted showing the relationship between the river level, the area and the hydrostatic pressure in the river.

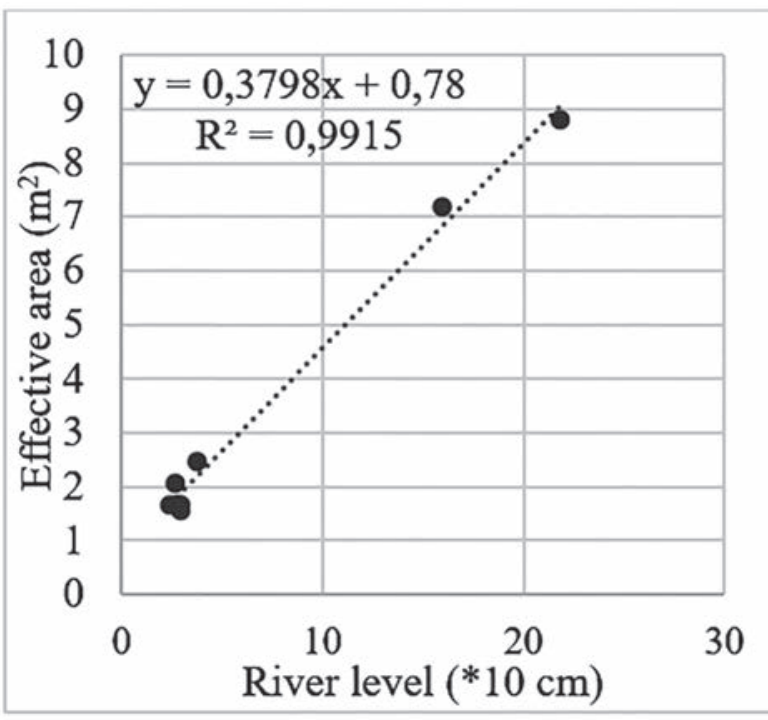

Figure 2 - Relation between area and river level.

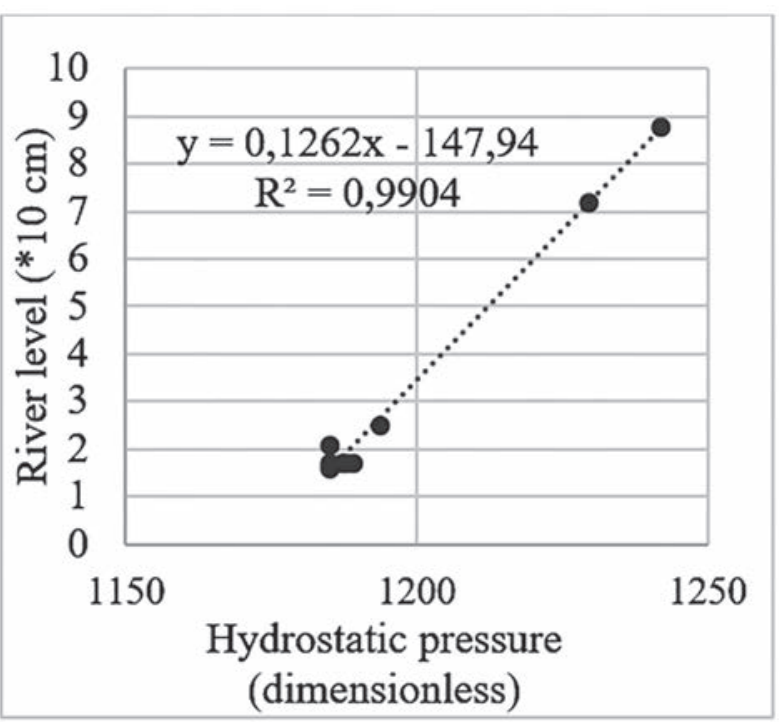

Figure 3 - Relation between hydrostatic pressure and river level.

Considering that flows determined by the flotation method and the ones made with the current meter, the following correlations were obtained: 


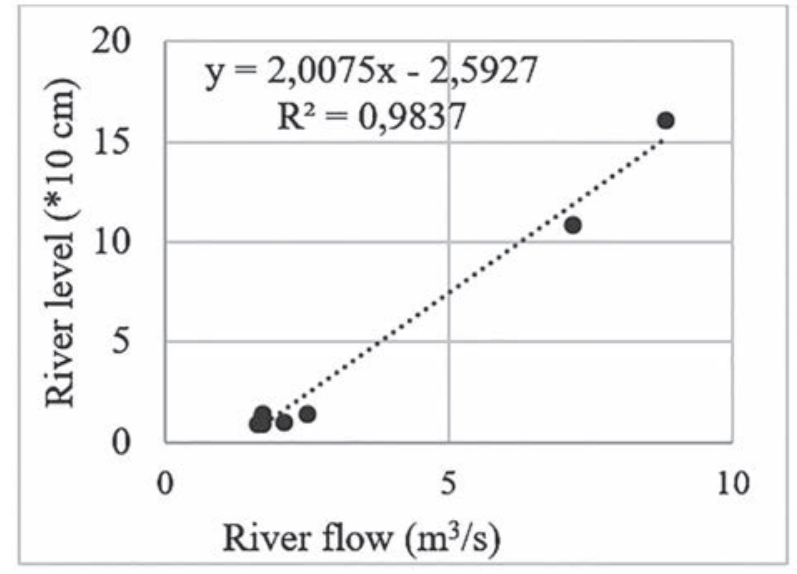

Figure 4 - Flow vs river level.

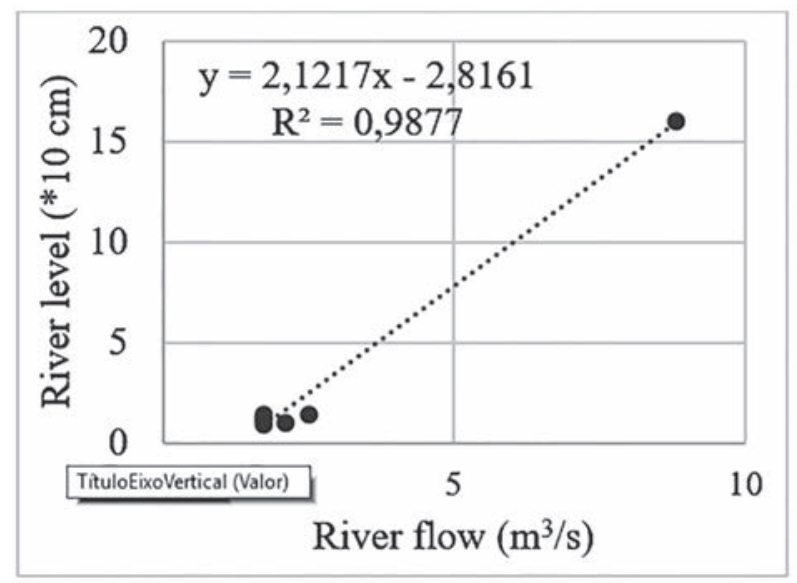

Figure 5 - Flow determined with current meter vs. river level.

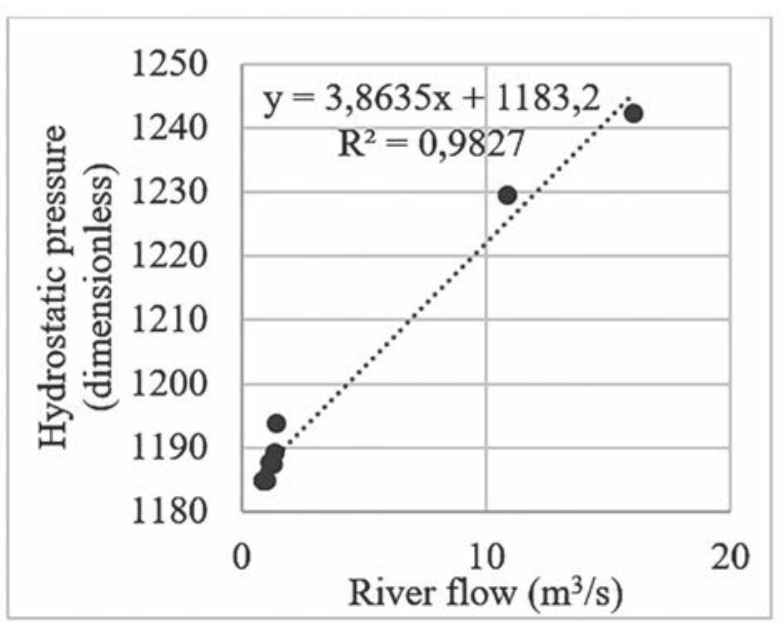

Figure 6 - Flow vs hydrostatic pressure.

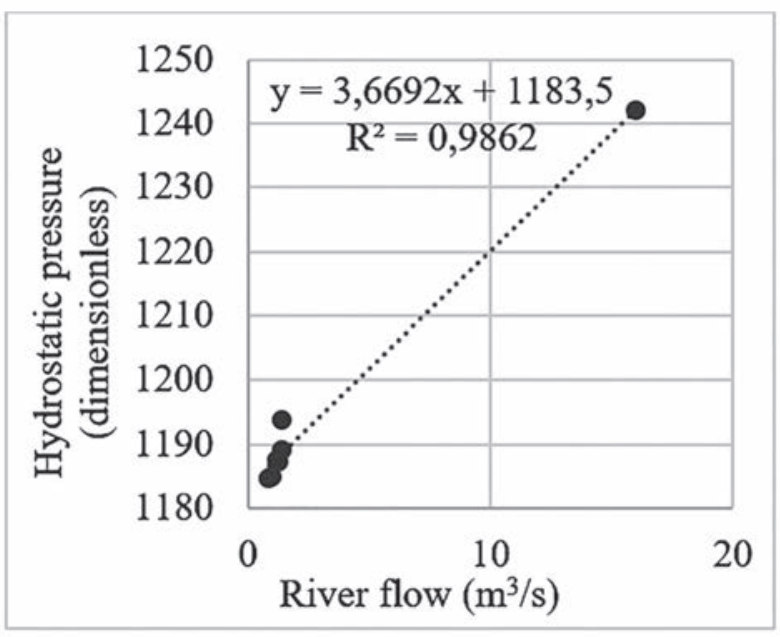

Figure 7 - Flow determined with current meter vs. hydrostatic pressure.

\section{Precipitation inside the basin}

To make the correlations of rainfall in the area, the rain gauge installed near the Ochomogo Riverwasused in the farm within which the monitoring equipment is located, because it has the most complete records. The precipitation data in the study a rea and the data from official meteorological stations (monitored by INETER) were compared in ord er to validate the values obtained from the installed rain gauges. Theinformationis presented in Table 2 and Table3, respectively.

Table 2 - Precipitation data of rain gauge No. 1 for November.

\begin{tabular}{lc}
\hline \multicolumn{1}{c}{ November } & mm of rain \\
\hline Total & 104,00 \\
\hline Average & 3,355 \\
\hline Average by event & 8,00 \\
\hline Maximum & 37,00 \\
\hline
\end{tabular}


Table 3 - Official data for November reported by INETER.

\begin{tabular}{lc}
\hline \multicolumn{1}{c}{ November } & mm of rain \\
\hline $\begin{array}{l}\text { Total number of } \\
\text { years evaluated }\end{array}$ & 41 \\
\hline Average & 174 \\
\hline Maximun & 461.3 \\
\hline Minimum & 38,9 \\
\hline
\end{tabular}

The data obtained from rain gauge No. 1, located in the study area, were obtained graphs that represent the relationship between the flows and the rainfall on the day the measurement was made.

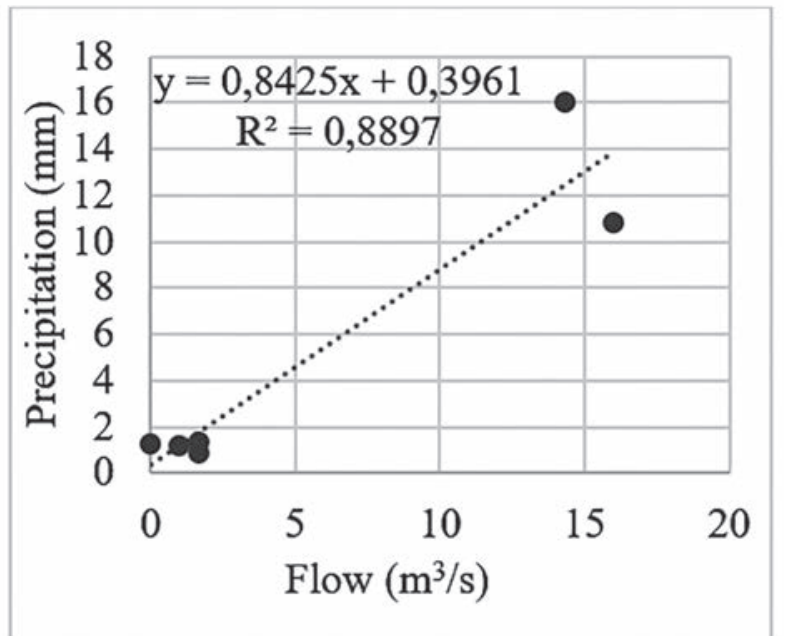

Figure 8 - Relation between flow and precipitation reported the day of measurement.

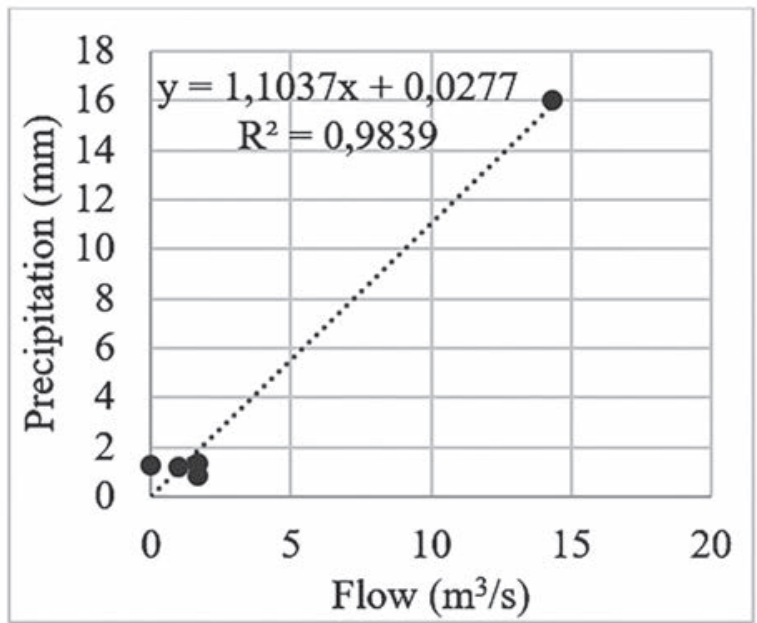

Figure 9 - Relation between flow with current meter and precipitation the day before measurement.

\section{Determination of}

\section{solids in water}

Table 4 shows the conc entrations of total, volatile and fixed solids, as well as the total suspended solids and the LED sensor rea dings.

From the data presented in Table 1 and Table 4 correlations were made between the LED readings and the variation of the flow, with the alterations of the solids in the river.

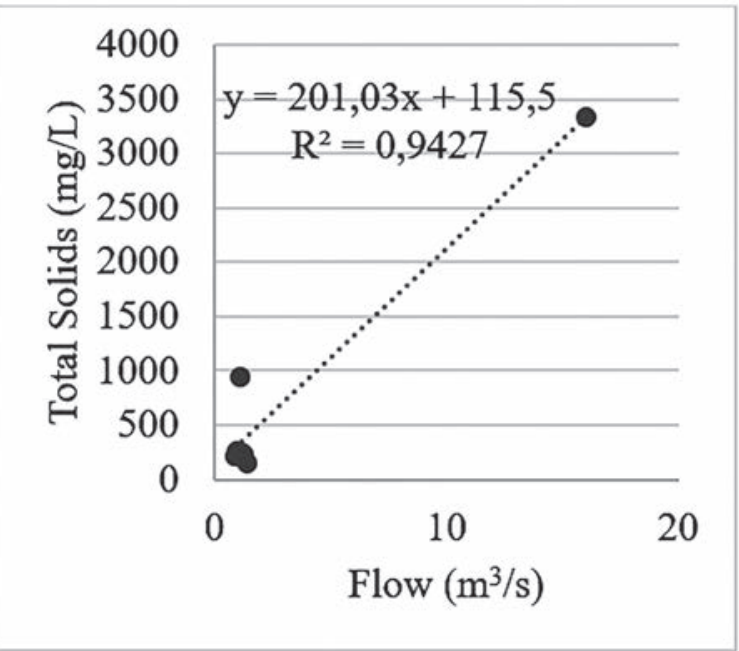

Figure 10 - Relation between flow and total solids concentration. 
Table 4 - Values of total solids, volatile and fixed components.

\begin{tabular}{ccccccc}
\hline No & $\begin{array}{c}\text { Sampling } \\
\text { day }\end{array}$ & $\begin{array}{c}\text { Totales } \\
\text { Solids } \\
\text { (mg/L) }\end{array}$ & $\begin{array}{c}\text { Total Volatile } \\
\text { Solids (mg/L) }\end{array}$ & $\begin{array}{c}\text { Total Fixed } \\
\text { Solids } \\
\text { (mg/L) }\end{array}$ & $\begin{array}{c}\text { Total } \\
\text { Suspended } \\
\text { Solids (mg/L) }\end{array}$ & $\begin{array}{c}\text { FED } \\
\text { Frequency }\end{array}$ \\
\hline 1 & $16 / 09 / 26$ & 270 & 100 & 170 & 40 & 1826 \\
\hline 2 & $16 / 10 / 10$ & 940 & 500 & 440 & 340 & 1634 \\
\hline 3 & $16 / 10 / 17$ & 215 & 105 & 110 & 15 & 0 \\
\hline 4 & $16 / 10 / 31$ & 235 & 155 & 80 & 40 & 106 \\
\hline 5 & $16 / 11 / 02$ & 3340 & 1390 & 1950 & 3890 & 10 \\
\hline 6 & $16 / 11 / 11$ & 145 & 95 & 50 & 26 & 8 \\
\hline 7 & $16 / 11 / 14$ & 245 & 95 & 150 & 30 & 92 \\
\hline
\end{tabular}

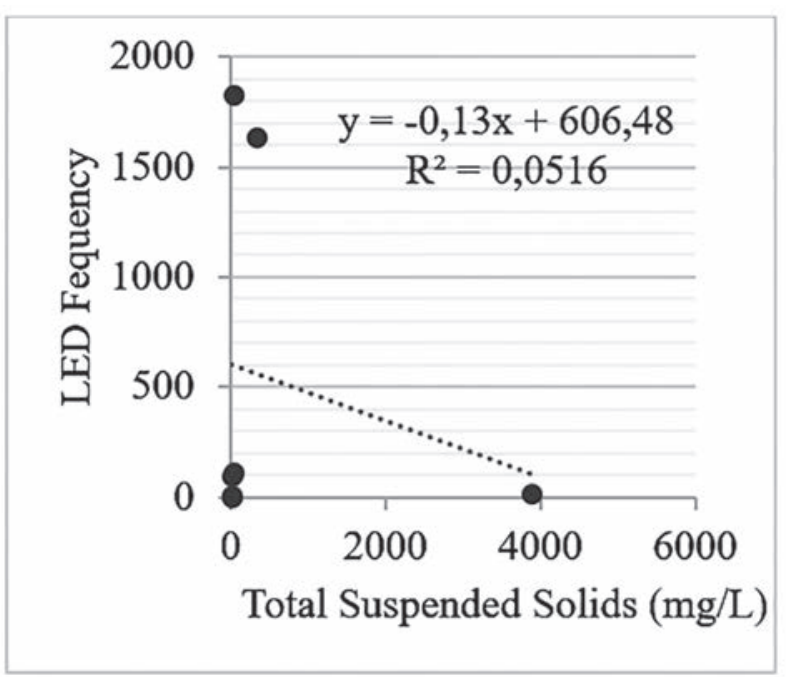

Figure 11 - Relation between total suspended solids and LED sensor reading.

\section{Discussion \\ F 7 OW}

The channel of the river where the flow measurements were made consists of a width of 30,10 meters. When measuring the cross section it had a maximum height of 1,68 meters, an area of 42,74 square meters and perimeter of 62,70 meters.
Under normal conditions, the riverbed in this section would only be 15 meters to 16,50 meters wide, but during heavy precipitation events, it covers the total visible wid th of the channel.

When doing the topographic survey of the cross section, it can be predicted, by means of the equation on Figure 2, the effective area or area used by the water that crosses the channel.

The flow measurements were made using the area/velocity method with two different techniques: the determination of the water velocity with the velocity meter and the floater method. For each case, two correlations are presented, which show that the measurements made with the velocity meterhas a slight increase in the correlation of the data, which ranges from 0,0035 to 0,0040 , with the exception of Figure 9, in which the relation between precipitation and flow rate increases by almost $10 \%$, that is to say that the flow 
obtained by the flotation method is rela tively close to a real value.

For the a forementioned, it was possible to develop a set of equations that allowed monitoring the river in real time, from a nywhere on the world that has access to the intemet. The determination of the flow was made possible by developing the equation presented in the Figure 7. On the monitoring web page, hydrostatic pressure is obta ined, which, when substituted, yields a flow rate with a precision percentage of $98,62 \%$.

To obtain the values of width and height of the channel that's occupied by the volume of water, the equations on Figures 2 and Figure 3 are used, which, having the hydrostatic pressure of the river, obta in the level and by means of the cross section measures the volume can be calculated, so width and length that the water occupies at that moment, under a correlation greater tha n $99 \%$.

\section{Precipitation}

The rain gauges installed have a diameter of $11,5 \mathrm{~cm}$ and therefore a surface of $330 \mathrm{~cm}^{2}$. In these, $33 \mathrm{~cm}^{3}$ equals one millimeter of rain, therefore, it was adapted to be recorded every $11 \mathrm{~cm}^{3}$, so it has an accuracy of $0,33 \mathrm{~mm}$ of rain. Both pluviometers show similar behavior, but for the validation of the data, only the one closest to the river was used, since it has more record.

The comparison was made with the Nanda ime rainfall station, which according to table 3. Presents historical values for the month of November between 38,9 and $461,3 \mathrm{~mm}$ of rain, and an a verage of $174 \mathrm{~mm}$. The data obtained by the rain gauge No 1. Present a total of $104 \mathrm{~mm}$ of rain during the month, being within the historical range, thus allowing the use of this data for the run of the hydrological model.

Figure 9 shows the proportionality that exists between the precipitation within the basin and the flow of the studied channel. Theoretic ally, it is known that the greater the precipitation in the basin, the greater the flow within the channel, this being different in each basin due to its hyd rolog ic al cha ra c teristic s. O bta ining a $98 \%$ relia bility equation with a single ra in gauge installed near the control site is not considered signific ant to determine the flow rate at the study site, as it does not provide suffic ient information on the a mount of rain that may fall on the entire basin.

\section{Sediments}

Table 4 shows the conc entrations of solids that the Ochomogo River discharges to Lake Cocibolca. When correlating the tota I solids vs the flow at the time of taking the sample (Figure 10), it corroborates that the higher the flow, the more turbulent the flow, which favors the lifting and mixing of the solids, considerably increasing the conc entrations for these.

The flow increases as precipitation increases, a part of the water that falls, infiltra tes and a nother is transported to the ma in channel by means of runoff that drag part of the organic matter present in the soil, for this reason approximately $50 \%$ of 
the total solids a re volatile, which means that they a re calc inated at $550^{\circ} \mathrm{C}$, which is characteristic of all the organic matter that is transformed into $\mathrm{CO}_{2}$ and $\mathrm{H}_{2} \mathrm{O}$.

The main point to improve in the research is the relationship and calibration of the LED sensor with the a mount of total suspended solids, a parameter that gives turbidity to water, since at first sight there is no logical relation and the fluctuations in the values a re very large, when performing a data correlation a value of $5 \%$ is obta ined considering it null.

This null correlation can be given by the placement of the sensor, which has a led located in a $90^{\circ}$ position, which could

\section{References}

AMERICAN PUBLIC HEALTH ASSOCIATION, 1998. Standard Methods for the Exaination of Water and Wastewater (20th ed.). Washington DC: American Public Health Association.

INTERNATIONAL BANK FOR RECONSTRUCTION AND DEVELOPMENT, 2013. Policy and Investment Priorities to Reduce Environmental Degradation of the Lake Nicaragua Watershed (Cocibolca). Washington DC: Environment \& Water Resources.

KELLEY, C., KROLICK, A., BRUNNER, L., BURKLUND, A., KAHN, D., BALL, W., and SHIRK, M., 2014. An Affordable Open-Source Turbidimeter. Sensors, vol. 14, pp. 7142-7155. mean that at low concentrations the light is scattered and the sensor can detect it, but at high concentrations, the light is blocked and the sensor does not detect brightness at all.

The more data or measurements are made, the equations will be developed to achieve a better correlation. The investigation wasstopped on November 15th because the companies that grow cane and rice in the surrounding areas close the dam located next to the PanAmerican highway, and it is well known that the flow cannot be measured before a dam because it obtains stagnant water readings.

NICARAGUAN INSTITUTE OF TERRITORIAL STUDIES, 2014. Hydrographic Basins of Nicaragua under the Pfafstetter methodology. Managua: Nicaraguan Institute of Territorial Studies.

WAGNER, R., BOULGER, R., OBLINGER, C. and SMITH, B., 2006. Guidelines and Standard Procedures for Continuous Water-Quality Monitors: Station Operation, Record Computation, and Data Reporting. U.S. Geological Survey Techniques and Methods 1-D3, p. 51.

WORLD METEOROLOGICAL ORGANIZATION, 2011. Hydrology - From Measurement to Hydrological Information. Ginebra: World Meteorological Organization. 



\section{Using MQual 1.5 Modelling to Assess the Water Quality of a Subtropical Catchment}

Honda, F.P., Matsumura-Tund isi, T. ${ }^{1}$, Tund isi J .G. ${ }^{1}$

International Institute of Ecology and Environmental Management - IIEGA, Brazil. Corresponding author: takako@iie.com.br

\section{Abstract}

The a im of this research was to study the point and non-points sources of the catchment of Agua Branca stream located, in Itira pina municipality, São Paulo State. Various sc enarios were proposed in order to a nalyze the behaviors of BOD5 days at $20^{\circ} \mathrm{C}$ and dissolved oxygen along with physic al and chemic al pa ra meters mea sured in situ with the data on total nitrogen, total phosphorus, total and fecal coliforms obtained in the laboratory, from samples of six station in the stream, if was possible to distribute spatially the components and represent this graphic ally. The data showed that the situation of the water quality of the stream Agua Branca is critical and a new sewage treatment plant is urgent required. Of the va rious scenarios studied if was demonstrated that if the diffuse load was reduced by $20 \%$ in the agric ultural area better water quality was achieved in the stream. With an increase in the agric ultural activity, a $50 \%$ dec rease in water quality could occur. For point sources, the best scena rio was the construction of a new wastewater treatment plant. The worst scenario for point source was the non-implementation of this new wastewater trea tment plant of Itira pina town.

Keywords: non point sources; point sources; mathematic al modeling (MQ ual 1.5); land use; water qua lity, scenarios. 


\section{Introduction}

The quality and qua ntity of water is dependent of the soil use, the hydrologic al cycle and water availability. The multiple uses of water a ffect both water quality and water quantity. Wa ter qua lity results from natural phenomenon such as surface runoff, infiltration of soil impurities, soil cover and a nthropic a ctivities such as domestic and industrial waters, agric ultural pestic ides, land use and occupation and untreated waste waterfrom urban a reas.

In watersheds loads from human activities a re key factors to degrade water qua lity of strea ms, lakes rivers a nd reservoirs. Softwa res with advanced technologies are used in order to determine the impacts of loads from point and non-point sources in the surface aquatic ecosystems. By classifying land use in the area of influence, it is possible to locate point and non-point sources of pollution. Export coeffic ients are used to complete the load scenarios, from the different areas.

The present research work wascarried out in order to evaluate the water quality of the Agua Branca stream as well to study the effects of loa ds from point and non-point so urces. The land use, land occupation population growth, were used in different scenarios. This can provide the necessary tools from planning, management and restoration of the stream Agua Branca.

\section{Material and Methods}

\section{Study site}

The Água Branca stream ispart of the Itaqueri river basin, one of its tributaries that most genera te all nutrients (BOD, total and fecal coliforms, phosphorus and nitrogen, among others). These are from the discharge of sewage from the munic ipa lity of Itirapina, located near the source of the stream. As a receiver of Itira pina sewage, it is the most degraded of water bodies evaluated in this study, besides being the main contributor of nutrients and fecal coliforms to the Lobo reservoir, through the Itaqueni river.

The Water and Sewage Division (DAE) of the munic ipality of Itirapina, responsible for the distribution and control of water consumption, and to carry out the collection and treatment of sewage, sta tes that the municipality has seven deep wells to collect water to attend all population, and a sewage trea tment plant that treats $72 \%$ of the sewage produced.

The old station has been operating for more than twenty years, that is, above its limit, which has a lrea dy caused legal problems for the munic ipa lity of Itira pina. To address this problem, the new treatment plant will have a 20-year service life and the ability to treat 80 liters of sewage per second. 
Another relevant aspect to be evaluated is the use of the soil in the watershed of the Água Branca stream. This a rea presents urban uses (Itirapina), reforestation (Pinus and Eucalyptus), a gricultura I a c tivities (orange and sugar cane), natural forest, c errado, field, pasture, exposed soil.

In the watershed area of the Água Branca stream, sandy soils domina te, with more fertile soils due to the presence of basalt. The vegetation of cerrado if dominant is related to the type of soil, and replaced by the mesophyllous forest or forest of plateau in places with more fertile soils, where there is presence of basalt, and by riparian forests or swamps, near the courses rivers, in more wetland regions.

However, much of this natural vegetation has undergone anthropic changes that have modified the landscape. One of them is the substitution of part of this vegetation for the a gric ulture, impla ntation of sand mining in the banks of the river Ita queri and construction of the Lobo dam (Broa), with the impoundment of the river Ita queri, and river Lobo.

\section{Using MQUAL 1.5 for} simulating river and stream water quality based on point and non point sources and loads

To obtain non-point source loads, the land uses were classified in the following a spects:
1 - urban area;

2 - agric ultura I uses;

3 - natural forest;

4 - a rtificial reforest;

5 - pasture;

6 - Exposed soil;

7 - Field.

The following equation was used to estima te the diffuse load:

Diffuse Load $=$ Area $\left(\mathrm{km}^{2}\right) \times$

Export coefficient $\left(\mathrm{kg} / \mathrm{km}^{2}\right.$.day)

The coefficients were extracted from the MQUAL 1.5 model developed by the Environment Department of the State of São Paulo (SMA, 2003).

The estima te of loads of tota I phosphorus, total nitrogen, suspended solids, to tal coliforms and $\mathrm{BOD}_{5,20}$ the mean values of domestic sewage concentration were used (METCALF; EDDY, 1991).

The area for each use of soil was obtained using following data base and software:

- Digital database made available by ANA, composed of Hydrographic Basins, of dra inage, in 1: 1,000,000 scale (ANA, 2005);

- Digital database made available by the IBGE, consisting of Carta files International to millionths (1: 1,000,000) (IBG E, 1999);

- Arcview/Arcgis 9.3 softwa re with Spatial Analyst extensions and Arc HydroTools 9.0. 


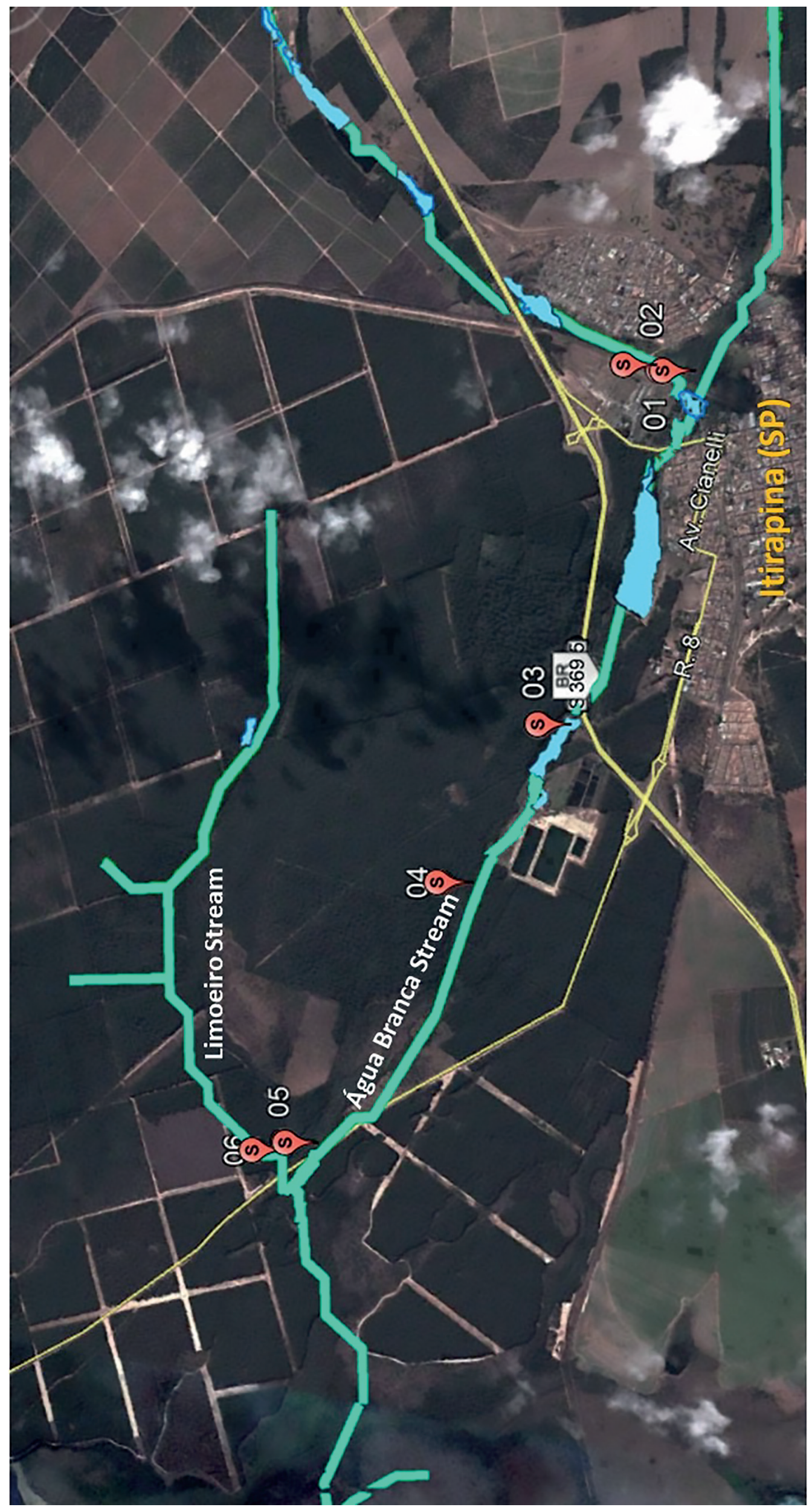

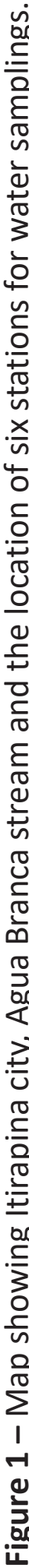


The point sourcesload wascalculated by the equation:

Point sources load $=150 L \times 0.80 \times$ Population $x$ Average Concentration $(\mathrm{mg} / \mathrm{L}$ )

The following parameters were adopted:

- Average water consumption In habitant/day: 150 Liters (SNIS, 2007);

- Percentage of water returning to the sewage network: $80 \%$ (VON SPERUNG, 1996);

- Current Population: 14,829 inhabitants (IBGE, 2009).

To obtain point sources loud was carried out samplings in the Agua Branca stream at six Stations (Figure 1) for physical-chemical and mic robiological analyzes, during the period of intensive rainfall: St1 located in the Agua Branca Stream; St2 on the tributarie 1 and downstream of the Sewage Treatment Plant, in operation; St3 and St4 at the downstream of the municipality; St5 at the tributa rie Limoeiro and St6 at outfa II of the river Itaqueri.

The following parameters such as: temperature, conductivity, dissolved oxygen, turbidity, total suspended solids, $\mathrm{pH}$, loc al depth, were measured were measured in the local using multi-para meter probe Horiba. Also it was been measured the velocity of the stream at the sampling points of the Água Branca stream and the tributa ries. GPS was essential for loc a ting station by providing a c curate la titude and longitude data.

Other analysis such as BOD for 5 days at $20^{\circ} \mathrm{C}\left(\mathrm{BOD}_{5,20}\right)$, total Nitrogen and total and fecal coliforms were carried out according Alpha (1988). Total phosphorus followed the method described by Valderrama (1981).

\section{Proposed scenarios for simulation

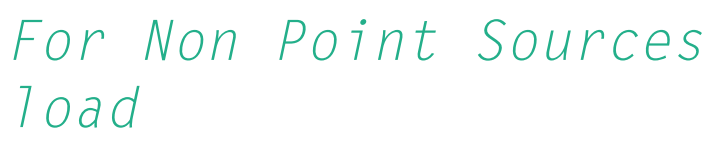

- Scenario 01: Reduction of $50 \%$ of the forest area with increase rela tive to the urban area;

- Scenario 02: Reduction of $50 \%$ of the forest area with increase rela tive to the agricultural area;

- Scenario 03: Reduction of $10 \%$ of the agricultural a rea with increase relative to the forest area;

- Scenario 04: Reduction of $20 \%$ of the agricultural area with increase relative to the area of reforestation.

Scenarios 1 and 2 present the more critic al situa tions, with deforesta tion of $50 \%$ of the forest area and growth of urban and a gric ultural area, while scenarios 3 and 4 present situations of improvement in the use of the soil in relation to the production of non-point loads. The improvement scenarios were useful to encourage the implementation of legal reserves on the properties or incentive to reforestation ac tivity that may be economic a lly viable for a gric ultura I producers. 


\section{For Point Sources load}

The point load sources in the munic ipality of Itira pina were estimated for the current sc enario without sewage trea tment (14.829 inhabitants a c cording to IBGE, 2009); with treatment of $73 \%$ of the sewage produced, according to information from Itira pina's Water Depa rtment (DAE); a nd with an increase of $50 \%$ of the population considering that the Sewage Treatment Station would be deactivated due to the end of its useful life, a lso considering that a nother Sewage Treatment Station is not activated in operation.

For the point sources loads, the following scenarios were:

- Scenario 01: Current situation without treatment of the munic ipal sewage;

- Scenario 02: Wastewa ter treatment plant operating with efficiency of $73 \%$;

- Scenario 03: G rowth of $50 \%$ of the population in the river basin, with treatment station inactive.

\section{Results}

\section{Non point loads}

Table 1 and the Figure 2 show the total area of the Agua Branca stream watershed and the calculated area for different land uses.
Table 1 - Calculated área for different land uses of Agua Branca stream catchment.

\begin{tabular}{lcc}
\hline \multicolumn{1}{c}{ Land uses } & Area $\left(\mathrm{km}^{2}\right)$ & $\%$ \\
\hline Water & 0.315 & 0.79 \\
\hline Artificial reforest & 9.286 & 23.30 \\
\hline Exposeds oil & 6.462 & 16.21 \\
\hline Pasture & 4.761 & 11.95 \\
\hline Urban area & 2.078 & 5.20 \\
\hline Natural forest & 6.865 & 17.23 \\
\hline Agriculture & 7.076 & 17.75 \\
\hline Field & 3.076 & 7.56 \\
\hline Total area & 39.854 & 99.99 \\
\hline
\end{tabular}

Ascan be seen the reforestation represents the class with the largest area within the basin: $23.3 \%$, followed by agriculture, $17.75 \%$. The relationship between the agricultural area and the forest a rea, presents a lmost the same size. The urban use represents the smallest area within the basin, together with a reas of open field.

After obtaining the values of the land use and occupation, it was possible to estimate the non-point loads in the watershed of the Água Branca stream.

The tables 2, 3, 4, 5, 6 and 7 shows respectively the diffuse loads of total phosphorus, total nitrogen, BODc (Biochemical Demand for Carbon), BODn (Biochemic al Demand for nitrogen), Suspended Solids, Coliforms for each type of land use. 


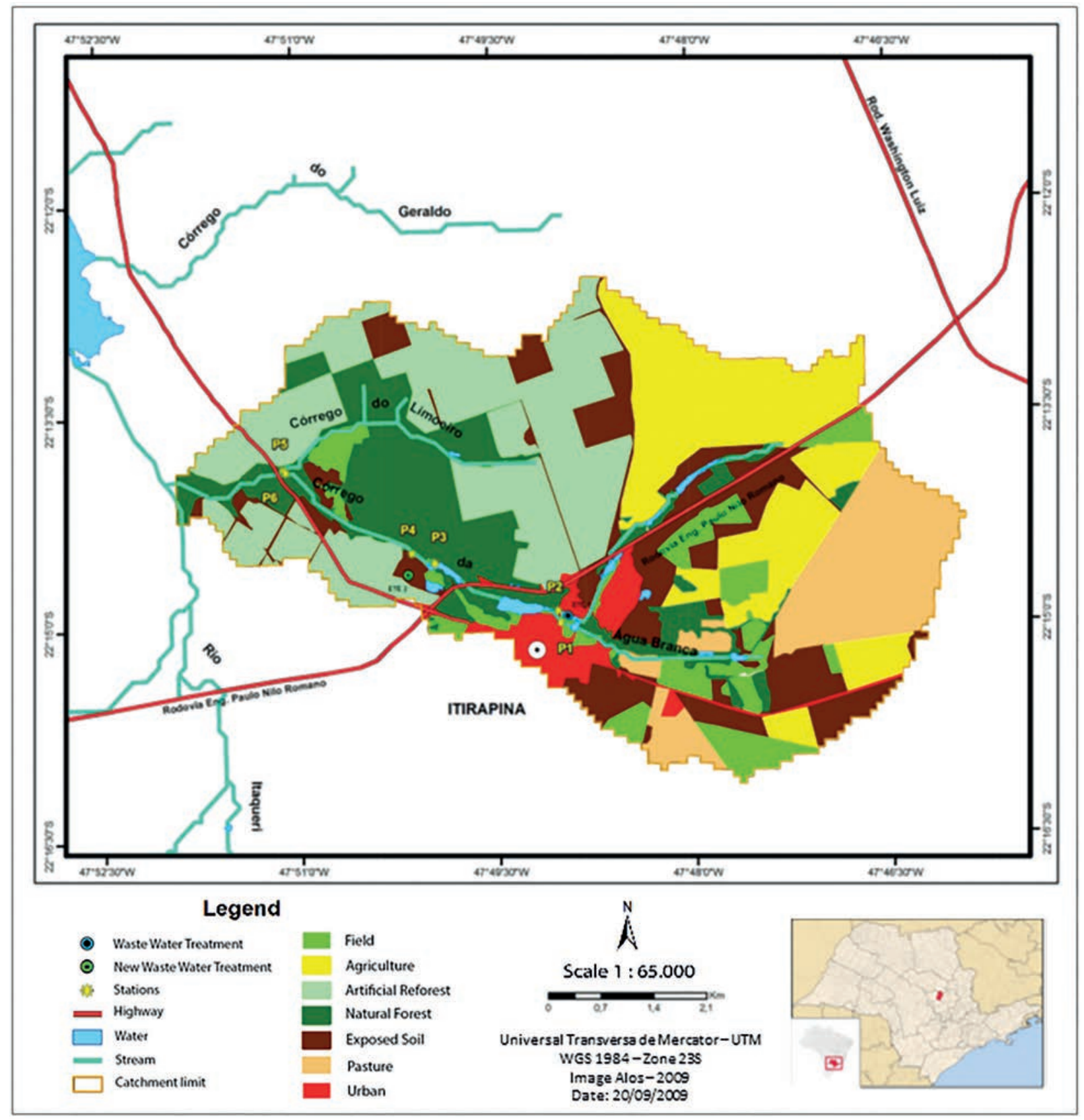

Figure 2 - Land use and occupation of the water catchment area of the Água Branca stream, Itirapina - SP. 
Table 2 - Coefficient ( $\mathrm{kg} / \mathrm{km}^{2} / \mathrm{day}$ ) and load ( $\mathrm{kg} /$ day) of total phosphorus for each type of land uses.

\begin{tabular}{|c|c|c|c|}
\hline Land use & Area $\left(\mathrm{km}^{2}\right)$ & Coefficient - P total $\left(\mathrm{kg} / \mathrm{km}^{2} /\right.$ day) & Load P (kg/day) \\
\hline Artificial Reforest & 9,286 & 0,039 & 0,363 \\
\hline Exposed Soil & 6,461 & 0,034 & 0,220 \\
\hline Pasture & 4,761 & 0,050 & 0,239 \\
\hline Urban area & 2,077 & 0,034 & 0,070 \\
\hline Natural Forest & 6,865 & 0,039 & 0,268 \\
\hline Agriculture & 7,075 & 0,346 & 2,448 \\
\hline Field & 3,011 & 0,028 & 0,084 \\
\hline Total & 39,539 & & 3,692 \\
\hline
\end{tabular}

Table 3 - Coefficient $\left(\mathrm{kg} / \mathrm{km}^{2} /\right.$ day) and load ( $\mathrm{kg} /$ day) of total nitrogen for each type of land uses.

\begin{tabular}{lccc}
\hline \multicolumn{1}{c}{ Land use } & Area $\left(\mathbf{k m}^{\mathbf{2}}\right)$ & Coefficient $\mathbf{N}\left(\mathbf{k g} / \mathbf{k m}^{2} /\right.$ day) & Load N (kg /day) \\
\hline Artificial Reforest & 9,286 & 0,600 & 5,572 \\
\hline Exposed Soil & 6,461 & 1,274 & 8,232 \\
\hline Pasture & 4,761 & 0,900 & 4,285 \\
\hline Urban area & 2,077 & 1,274 & 2,647 \\
\hline Natural Forest & 6,865 & 0,600 & 4,119 \\
\hline Agriculture & 7,075 & 2,950 & 20,874 \\
\hline Field & 3,011 & 0,500 & 1,506 \\
\hline Total & 39,539 & & 47,235 \\
\hline
\end{tabular}

Table 4 - Coefficient ( $\mathrm{kg} / \mathrm{km}^{3} /$ day) and load ( $\mathrm{kg} /$ day) of BODc for each type of land uses.

\begin{tabular}{lccc}
\hline \multicolumn{1}{c}{ Land use } & Area $\left(\mathbf{k m}^{\mathbf{2}}\right)$ & Coefficient BODc $\left(\mathbf{k g} / \mathbf{k m}^{2} /\right.$ day) & Load BODc (kg/day) \\
\hline Artificial Reforest & 9,286 & 1,302 & 12,091 \\
\hline Exposed Soil & 6,461 & 4,000 & 25,848 \\
\hline Pasture & 4,761 & 2,000 & 9,523 \\
\hline Urban area & 2,077 & 4,000 & 8,311 \\
\hline Natural Forest & 6,865 & 1,302 & 8,938 \\
\hline Agriculture & 7,075 & 7,564 & 53,522 \\
\hline Field & 3,011 & 1,079 & 3,248 \\
\hline Total & 39,539 & & 121,480 \\
\hline
\end{tabular}


Table 5 - Coefficient ( $\mathrm{kg} / \mathrm{km}^{3} /$ day) and load ( $\mathrm{kg} /$ day) of BODn for each type of land uses.

\begin{tabular}{lccc}
\hline \multicolumn{1}{c}{ Land use } & Area $\left(\mathbf{k m}^{\mathbf{2}}\right)$ & Coefficient BODn $\left(\mathbf{k g} / \mathbf{k m}^{2} / \mathbf{d a y}\right)$ & Load (kg BODn/day) \\
\hline Artificial Reforest & 9,286 & 1,197 & 11,116 \\
\hline Exposed Soil & 6,461 & 5,535 & 35,767 \\
\hline Pasture & 4,761 & 2,250 & 10,713 \\
\hline Urban area & 2,077 & 5,535 & 11,501 \\
\hline Natural Forest & 6,865 & 1,197 & 8,217 \\
\hline Agriculture & 7,075 & 7,315 & 51,760 \\
\hline Field & 3,011 & 1,064 & 3,204 \\
\hline Total & 39,539 & & 132,277 \\
\hline
\end{tabular}

Table 6 - Coefficient $\left(\mathrm{kg} / \mathrm{km}^{3} /\right.$ day) and load $(\mathrm{kg} /$ day) of suspended solids for each type of land uses.

\begin{tabular}{|c|c|c|c|}
\hline Land use & Area $\left(\mathbf{k m}^{2}\right)$ & Coefficient S.S (kg/km²/day) & Load Susp. Sol. (kg/day) \\
\hline Artificial Reforest & 9,286 & 20 & 185,725 \\
\hline Exposed Soil & 6,461 & 50 & 323,095 \\
\hline Pasture & 4,761 & 40 & 190,453 \\
\hline Urban area & 2,077 & 50 & 103,891 \\
\hline Natural Forest & 6,865 & 20 & 137,301 \\
\hline Agriculture & 7,075 & 230 & 1627,443 \\
\hline Field & 3,011 & 30 & 90,332 \\
\hline Total & 39,539 & & $2.658,239$ \\
\hline
\end{tabular}

Table 7 - Coefficient $\left(\mathrm{kg} / \mathrm{km}^{3} /\right.$ day) and load ( $\mathrm{kg} /$ day) of coliforms for each type of land uses.

\begin{tabular}{lccc}
\hline \multicolumn{1}{c}{ Use } & Area $\left(\mathbf{k m}^{\mathbf{2}}\right)$ & $\begin{array}{r}\text { Coefficient Coliforms } \\
\mathbf{( k g / \mathbf { k m }} \mathbf{2} / \mathbf{d a y})\end{array}$ & $\begin{array}{c}\text { Load Coliforms } \\
\mathbf{( k g / d a y})\end{array}$ \\
\hline Artificial Reforest & 9,286 & $1,00 \mathrm{E}+08$ & $9,29 \mathrm{E}+08$ \\
\hline Exposed Soil & 6,461 & $1,00 \mathrm{E}+09$ & $6,46 \mathrm{E}+09$ \\
\hline Pasture & 4,761 & $1,00 \mathrm{E}+09$ & $7,76 \mathrm{E}+09$ \\
\hline Urban area & 2,077 & $1,00 \mathrm{E}+09$ & $2,08 \mathrm{E}+09$ \\
\hline Natural Forest & 6,865 & $1,00 \mathrm{E}+08$ & $6,87 \mathrm{E}+08$ \\
\hline Agriculture & 7,075 & $1,00 \mathrm{E}+11$ & $7,08 \mathrm{E}+11$ \\
\hline Field & 3,011 & $1,00 \mathrm{E}+08$ & $3,01 \mathrm{E}+08$ \\
\hline Total & 39,539 & & $7,23 \mathrm{E}+11$ \\
\hline
\end{tabular}


After obtaining the diffuse load estimates, they were evaluated for the proposed scenarios. Table 8 shows the sc enarios of diffuse loads in the watershed of the Agua Branca stream, using loadsfor total phosp horus, total nitrogen, biochemic al demand of carbon, biochemic al demand of nitrogen suspended solids and total coliforms.

The following results a re presented:

- For scenario 1 (reduction of $50 \%$ of the natural forest area, and increase of the urban area) it was observed a reduction of $0.47 \%$ of the load of $P$, increases of $13.4 \%$ of the load of $N, 7.62 \%$ of the BODC load, $11.25 \%$ of the BODn load. It does not occurred high difference among the suspended solids load and the total coliform load;

- For scenario 2 (reduction of $50 \%$ of the natural forest area, and increase of the area of agric ultural use) there were increa ses of $27.74 \%$ of the load of $\mathrm{P}, 16.17 \%$ of the load of $\mathrm{N}$, of $17.7 \%$ of the BODc load, $15.87 \%$ of the BOD load, $17.12 \%$ of the suspended solids load and $47.44 \%$ of the total coliform load;

- For scenario 3 (a reduction of $10 \%$ of the agricultural area with an increase relative to the natural forest area) there was a reduction of $5.72 \%$ of the load of $P$, but did't show any significant change in the loads of total N, BODC, BODn, suspended solids and total coliforms;

- For scenario 4 (a reduction of $20 \%$ of the agricultural area with an increase relative to the reforestation area), there was a reduction of $11.44 \%$ of the load of $P, 6.67 \%$ of the $\mathrm{N}$ load, $7.3 \%$ of the BODc load, $6.55 \%$ of the BOD load, $11.18 \%$ of the suspended solids load and $19.56 \%$ of the total coliform load;

- With this it can be observed that the most critical case was scenario 2 , presenting signific ant increases in the loads; it is the most common situation currently. The best scenario for diffuse loads was the 4 , due to the significant reduction of the loads of P, N, BODC, BODn, suspended solids and coliforms.

This a lterna tive could contribute to the improvement of the water quality of the Água Branca stream and encourage reforestation a ctivities that a re of great ecological and economic importance in Itirapina and the region.

Table 8 - Scenarios of diffuse loads in the watershed of the Água Branca stream.

\begin{tabular}{lcccccc}
\hline \multicolumn{7}{c}{ Diffuse loads in different scenarios } \\
\hline & $\begin{array}{c}\mathbf{P} \\
\text { (kg/day) }\end{array}$ & $\begin{array}{c}\mathbf{N} \\
\mathbf{( k g / d a y )}\end{array}$ & $\begin{array}{c}\text { BODc } \\
\mathbf{( k g / d a y )}\end{array}$ & $\begin{array}{c}\text { BODn } \\
\mathbf{( k g / d a y )}\end{array}$ & $\begin{array}{c}\text { SS } \\
\mathbf{( k g / d a y )}\end{array}$ & $\begin{array}{c}\text { Total Coliforms } \\
\text { (kg/day) }\end{array}$ \\
\hline $\begin{array}{l}\text { Current } \\
\text { Scenario }\end{array}$ & 3,69 & 47,23 & 121,48 & 132,28 & $2.658,24$ & $7,23 \mathrm{E}+11$ \\
\hline Scenario 1 & 3,78 & 56,57 & 130,74 & 147,17 & $2.761,21$ & $7,26 \mathrm{E}+11$ \\
\hline Scenario 2 & 4,85 & 57,95 & 142,97 & 153,28 & $3.379,07$ & $1,07 \mathrm{E}+12$ \\
\hline Scenario 3 & 3,58 & 49,88 & 121,48 & 132,28 & $2.658,24$ & $7,23 \mathrm{E}+11$ \\
\hline Scenario 4 & 3,36 & 46,56 & 112,62 & 123,62 & $2.361,05$ & $5,81 \mathrm{E}+11$ \\
\hline
\end{tabular}




\section{Point sources loads}

The chemical and physical parameters (tempera ture, cond uc tivity, dissolved oxygen, biochemic al oxygen demand $\left(\mathrm{BOD}_{5,20}\right)$ and $\mathrm{pH}$ measured at six stations in the Agua Branca stream and its tributaries are presented in the Table 9.

Also the hydraulic data such as width, section a rea, cha in speed, declivity, altitude and flow rate for each station were performed and presented in the Table 10.

The results obtained through the a na lysis of water samples collected at the six stations of the stream, showed the following situation for the water quality of the Agua Branca stream. Acording CONAMA Resolution 357/05 (2005), the quality of the water from Stations 1, 2, 3 could be considered as belonging to Class II and the water quality from 4,5,6 as Class III or some times IV.

The total coliform concentration was higher than 2,419.6 NMP/100 mL at all stations. The E. coli concentration was higher downstream of Point 2 and near Point 4 , respectively. The presence of total and fecal coliforms makes water from the Água Branca stream unfit for human consumption and for fishing and leisure activities.

Table 9 - Physical and chemical data obtained in the 6 stations located in the Agua Branca stream and in its tributaries.

\begin{tabular}{lccccccc}
\hline Parameter & Unity & St 1 & St 2 & St 3 & St 4 & St 5 & $\begin{array}{c}\text { St 6 } \\
\text { (downstream) }\end{array}$ \\
\hline Temperature & ${ }^{\circ} \mathrm{C}$ & 22,8 & 23,40 & 26,68 & 26,30 & 24,70 & 23,62 \\
\hline Conductivity & $\mathrm{uS} / \mathrm{cm}$ & 50 & 48 & 34 & 39 & 57 & 60 \\
\hline DO & $\mathrm{mg} / \mathrm{L}$ & 6,60 & 5,81 & 5,79 & 4,85 & 3,52 & 2,83 \\
\hline BOD & $\mathrm{mg} / \mathrm{L}$ & 3,561 & 7,00 & 7,00 & 6,29 & 6,30 & 5,21 \\
\hline pH & & 8,47 & 8,05 & 8,11 & 7,02 & 6,78 & 6,60 \\
\hline
\end{tabular}

Table 10 - Hydraulic data measured in the Água Branca stream.

\begin{tabular}{lccccccc}
\hline Parameter & Unity & St 1 & St 2 & St 3 & St 4 & St 5 & St 6 \\
\hline Width & $\mathbf{m}$ & 3,00 & 1,60 & Lagoon & 1,00 & 0,52 & 2,80 \\
\hline Section area & $\mathbf{m}^{\mathbf{2}}$ & 0,81000 & 0,042 & $\mathrm{xx}$ & 0,00446 & 0,00122 & 1,04 \\
\hline Chain speed & $\mathbf{c m} / \mathbf{s}$ & 5,84 & 40,2 & $\mathrm{xx}$ & 32,84 & 8,34 & 15,9 \\
\hline Declivity & $\mathbf{m} / \mathbf{m}$ & 0,0077 & tributary & 0,2857 & 0,009 & tributary & downstream \\
\hline Altitude & $\mathbf{m}$ & 768 & 760 & 748 & 748 & 724 & 724 \\
\hline Flow rate & $\mathbf{m}$ 3/s & 0,0473 & 0,017 & $\mathrm{xx}$ & 0,1465 & 0,0102 & 0,1653 \\
\hline
\end{tabular}


Considering the following simulation sc enarios:

- Scenario 01: Current situation without treatment of the municipal sewage;

- Scenario 02: Wastewater treatment plant operating with efficiency of $73 \%$;

- Scenario 03: Growth of $50 \%$ of the population in the river basin, with treatment station inactive, Table 11 presents the variation of the point source loads forvarious factors

The simulating scenarios show that the population growth is more important than the treatment of domestic sewage improving with $73 \%$ effic iency.

\section{Discussion}

The bad water quality of Água Branca stream of Itirapina city is determined ma inly by the poor effic iency of domestic sewage trea tment based in the current number of population ( point sources loads) associated by the inappropriate land uses. As it was demonstrated by simulation, the inc rea se in efficiency of sewage treatment in $73 \%$, reduce considerably the phosphorus, nitrogen, BOD ${ }_{c}, B O D_{n}$ and coliformsloads However when the population increases in $50 \%$ there is duplic ation of loads.

As it was demonstrated in the present analysis it was possible to distinguish between pollution from point sources and non point sources. Impacts on rivers, reservoirs and lakes from point sources a re originated mainly from discharge of wastewater. This is the case of the Agua Bra nca river that receives wastewater from Itira pina town. Acceptable solution therefore would be to construct the new wastewater trea tment plant that reduce the impact.

The water pollution problems associated with municipal wastewater include their content of:

- Nutrients causing eutrophic ation;

- Biodegradable organic matter causing oxygen depletion;

- Bacteria and virus affecting the sanitary quality of water which impa irs multiple uses (J O RGENSEN et al., 2013).

Table 11 - Variation of point source loads of variable factors for proposed scenarios.

\begin{tabular}{|c|c|c|c|c|c|}
\hline \multicolumn{6}{|c|}{ Variable factors } \\
\hline Scenarios & $\begin{array}{l}\text { P total } \\
\text { (kg/day) }\end{array}$ & $\begin{array}{l}\text { N total } \\
\text { (kg/day) }\end{array}$ & $\begin{array}{c}\text { BODc } \\
\text { (kg/day) }\end{array}$ & $\begin{array}{c}\text { BODn } \\
\text { (kg/day) }\end{array}$ & $\begin{array}{l}\text { Coliforms } \\
\text { (kg/day) }\end{array}$ \\
\hline $\begin{array}{l}\text { Current Situation (without } \\
\text { treatment) }\end{array}$ & 0,16 & 0,82 & 4,53 & 4,53 & $2.059 .583,33$ \\
\hline $\begin{array}{l}\text { Treatment with } 73 \% \\
\text { efficiency }\end{array}$ & 0,04 & 0,22 & 1,22 & 1,22 & $556.087,50$ \\
\hline $50 \%$ increase in population & 0,25 & 1,24 & 6,80 & 6,80 & $3.089 .375,00$ \\
\hline
\end{tabular}


If the identific ation of point sources is well determined as it is in the case of Agua Branca river, the load from non point sources is more diffic ult to measure. This is due to the highly dynamic character of the non point sources, to diverse soil uses, diffic ult to quantify loads with tra ditional hydrologic techniques and variability of values that range a cross several orders of magnitude.

Non struc tural c ontrol mea sures can offer a viable option for controlling non point sources in many dra ina ge basins. Changes in a gric ultural practic es could reduce signific antly phosphorus inputs

\section{References}

AGÊNCIA NACIONAL DE ÁGUAS (ANA). Disponibilidade e demandas de recursos hídricosno Brasil. Brasília, ANA. 2005.

ALPHA - AWWA - AMERICAN WATER WORKS ASSOCIATION. Standard methods for examination of water and wastewater. 20th. Washington: American Public Health Association. 1988.

CONAMA, 2005. Resolução do CONAMA 357. 17 de Março de 2005, Ministério do Meio Ambiente, Brasília.

GOOGLE. Google Earth website. Available in: http:// earth.google.com/. Access: 2009.

IBGE - Instituto Brasileiro de Geografia e Estatística, 2009.

IBGE. Mapoteca Digital Versão 04. Rio de Janeiro: IBGE/DGC/DECAR, 1999

JØRGENSEN, S.E., LÖFLER, H., RAST, W. and STRAŠKRABA, M. ${ }^{+}, 2005$. Lake and Reservoir Management. Developments in Water Science 54. Elsevier B.V., 502 pp. from a gric ultural runoff. Reducing fertilizers or pestic id es applied in a gric ultural fields reduces input to the river. Reforestation of watersheds is a nother possible ac tivity that concerns reducing sediment or suspended matter loa ds, nutrients, hea vy meta Is a nd organic substances (J ORG ENSEN et al, 2005).

Since so urces typ ic a lly a rise from extensive land a reas the use of models to simula te the loads is indicated. Effective pollution control programs involves farmers, urba $\mathrm{n}$ inhabitants; changes in huma $\mathrm{n}$ practices have the potential to reduce pollutants loads to rivers.

JØRGENSEN, S.E., TUNDISI, J.G. and MATSUMURATUNDISI, T., 2013. Handbook of Inland Aquatic Ecosystem Management. CRC Press, Taylor \& Francis Group. 422pp

METCALF and EDDY, 1991. Wastewater Engineering Treatment, Disposal and Reuse. Third Edition. McGraw-Hill, Inc., 1334 p.

IBGE, 2009. Resultado dos Dados Preliminares do Censo-2009. Available in: www.ibge.gov.br/cidade@.

SMA. Secretaria do Meio Ambiente do Estado de São Paulo. Versão 1.5 do Modelo de Correlação Uso do Solo/Qualidade de Água - MQUAL. 2003.

SNIS. Sistema Nacional de Informações sobre o Saneamento. Ministério das Cidades. 2007.

VARDERRAMA, J.C., 1981. The simultaneous analysis of total nitrogen and total phosphorus in natural waters. Mar. Chem. vol. 10, pp. 109-122.

VON SPERLING, M., 1996. Introdução à qualidade das águas e ao tratamento de esgotos. 2. ed. Belo Horizonte: DESA/UFMG. vol. 1, 243 p. 



\section{The Ecological Dynamics of UHE Carlos Botelho (Lobo/Broa) Reservoir: Temporal Changes}

Tund isi, J .G. ${ }^{1}$, Matsumura-Tund isi, T. ${ }^{2}$

${ }^{1}$ Feeva le University-Novo Ha mburgo, RS.

2Intemational Institute of Ecology, Sã o Ca rlos, SP.

Corresponding author: tundisi@iie.com.br

\section{Abstract}

The temporal and spatial variability of the aquatic ecosystems are fundamental processes in the ecological dynamic s of these ecosystems. Particularly in reservoirs these characteristics are very important. Detemining the hierarchic al relationships of these key mechanisms is an important step in the knowledge of the functioning of these artificial ecosystems. In order to develop a more comprehensive theory of reservoir dynamics in necessary to adapt a broader perspective encompassing physic al, chemical and biological responses coupled with the hierarchy of forcing functions. The objective of this paper is to present and disc uss the "tipping point concept" a pplied to UHE Carlos Botelho (Lobo/Broa) reservoir based on recent changes in the climatological forcing functions that produced several alterations in this reservoir ecologic al dyna mic s.

Keywords: reservoirs, ecological dyna mic s, climate, changes, tipping point concept, hierarchy. 


\section{Introduction}

Ec ologic al research at small a qua tic ec osystems is und oub ted ly an a dvanced development for the scientific understand of the limnology of these water systems. Reservoirs, partic ularly, can be very useful once they are controlled by man, have a known origin and age and provide water for a variety of a p plications. Small, shallow reservoirs, with a volume of a round $20.000 .000 \mathrm{~m}^{3}$ a re very much relevant since they can be used as a "qua si-experimental site" (MARG ALEF, 1966; EDMONDSON, 1994).

Such was the approach taken at the establishment of ecological and limnological research, in 1971 (TUNDISI; MATSUMURA-TUNDISI, 2013) at Lobo/Broa reservoir, a shallow, well mixed, subtropic al a rtific ial a qua tic ecosystem construc ted in 1936 to supply hydroelectric ity to the small town of Itira pina at that time.

The resenvoir has been monitored since then. It has a watershed area of $230 \mathrm{~km}^{2}$; an average depth of 3 meters; a maximum depth of 12 meters; the watershed is dominated by a savanna type of vegetation ("c errado"); a reas of reforestation with Pinus sp and Eucalyptus $\mathrm{sp}$; The soil of the watershed has a high concentra tion of aluminum and a reas with high iron concentration; the reservoir has an a rea of $7 \mathrm{~km}^{2}$, a width of $1 \mathrm{~km}$, and two spatial compartments.

The research and monitoring projects developed at Lobo/Broa reservo ir included a ll c lima tologic al, biologic al, physical, hydrologic al and chemical processes. During 47 years of this research and monitoring a clear understanding of the ma in climatologic al forc ing functions and the responses of the reservoir in terms of vertic al and horizonta I circulation and the biological communities was promoted.

Forcing functions as wind speed and direction, precipitation, and circulation and nutrient cycles were well known. Therefore the fluctuations during the climatologic al year, the response of the reservoir and the communities to these fluctuations and the succession processes a re known and described in severa I publications and books (TUNDISI; MATSUMURA-TUNDISI, 2013). Different stages of suc cession and stability were extremely repetitive showed by the many years of research, sampling and monitoring. (TUNDISI, 2017).

As Margalef (1966) pointed out, the strong fluctuations in the environment stop and change succession. Climatic changes a re among those fluctuation that interfere with succession, especially it they a re forcing functions that drive the ecosystem.

In this paper the a uthors disc uss the effects of c limate changes in the Lobo/Broa reservoir ecologic al dyna mic s. Suc cession of species, eutrophication and water quality were affected by a combination of climatic a Iterations, water uses and nutrient input due to human exploitation. Figures 1 and 2 show the location and general characteristic s of the watershed and reservoir. 


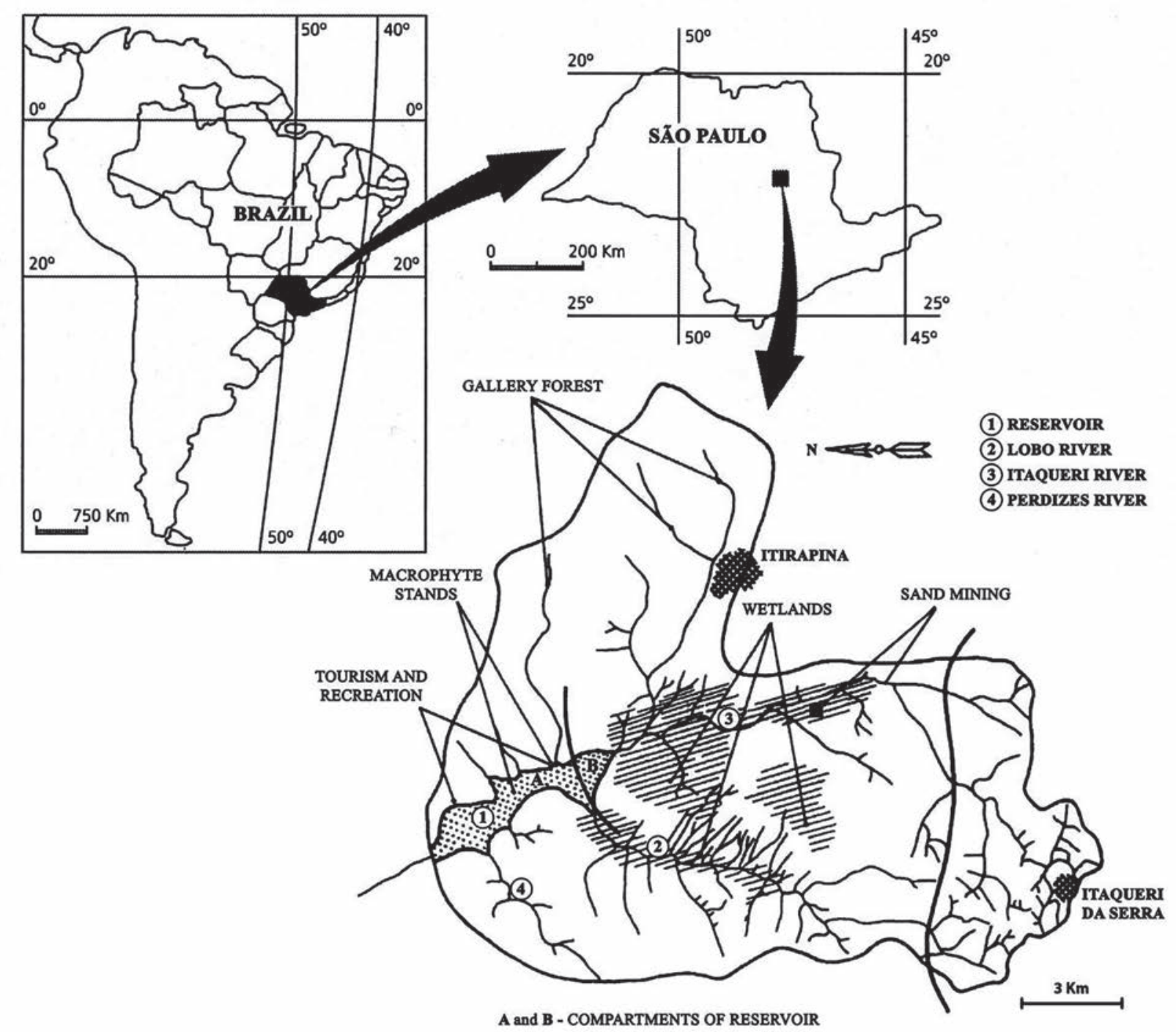

Figure 1 - Location of Itaqueri/Lobo watershed and UHE Carlos Botelho reservoir (Lobo/ Broa) in São Paulo State, Brazil. 


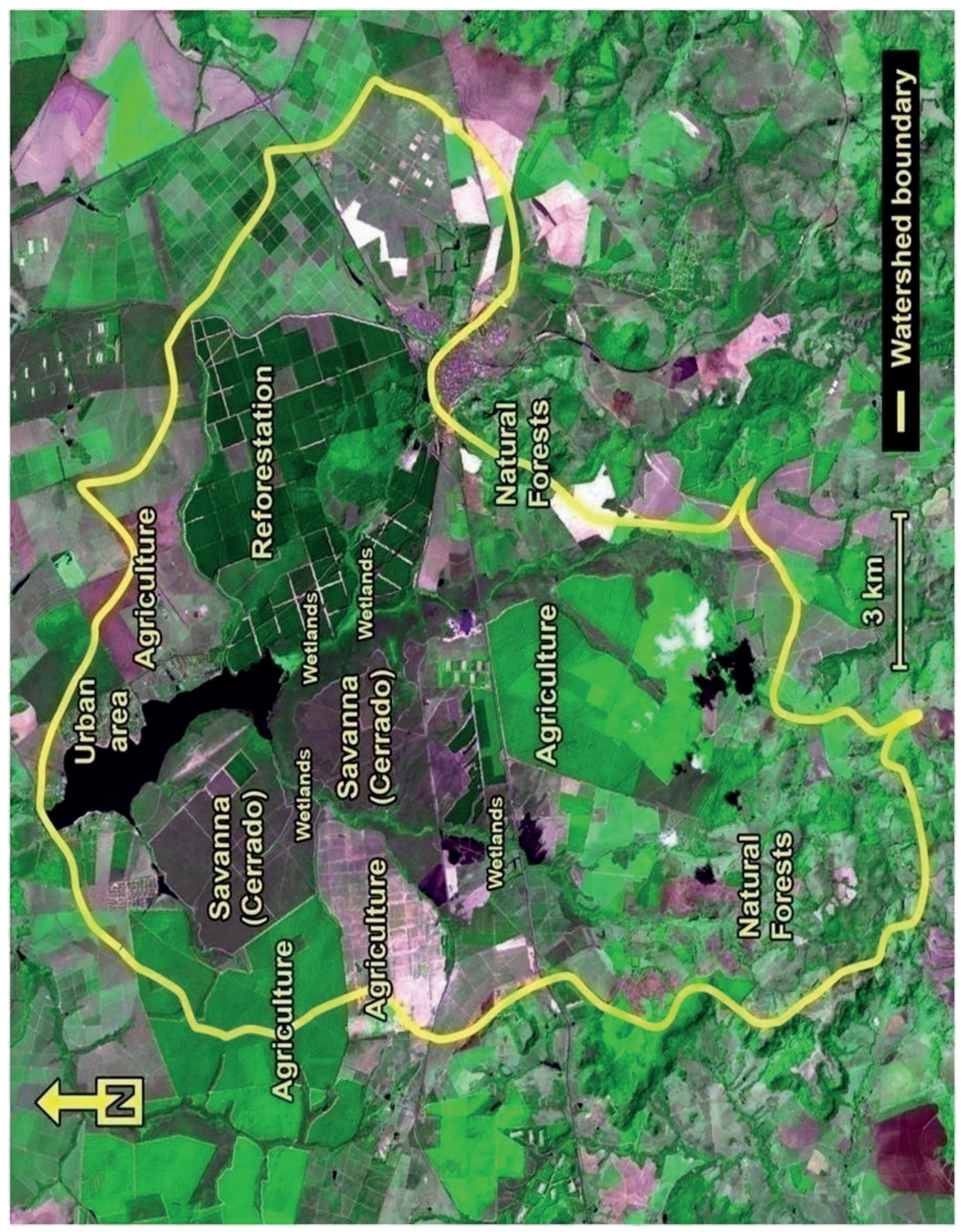

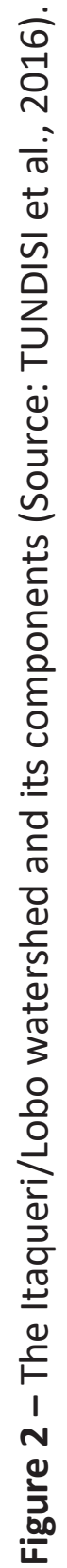


Description of main events

Throughout the many years of study a clearpic ture of the ecological dyna mics of the resenoir emerged. Fluctuations of the climatologic al forcing functions such as precipitation and wind, a ir and water temperature showed a regular fluctuation process that promoted responses of the reservoir: hidrogeochemical, hidrologic al, limnologic al and biological. This was predic table year after year (Figure 3).

The use of reservoir for hydroelectricity generation maintained a low retention time, , therefore low nutrient content in the water was detected. Due to permanent mixing promoted by wind (GRANADEIROS RIOS, 2003) phosphorus was forced to the sediment reducing also its concentration (dissolved inorganic phosphate) in the water column, therefore maintain a low phytoplankton biomass (TUNDISI, 2017).

This sequence of events lasted from 1971, first year of sa mpling and monitoring to 2015 , therefore 44 years.

In 2014 and 2015, changes in the precipitation, surface water temperature, and retention time occurred. The reduction of precipitation and the increase of $2^{\circ} \mathrm{C}$ in surface water temperature ( $2^{\circ} \mathrm{C}$ above the average surface temperature for 43 years), were attributed to climatologic al changes that affected the south east of Brazil in 2014 and 2015. (MARENG O et al.,
2015). Lower va lues of precipitation with values of less $250 \mathrm{~mm}$ in relation of the average during this period occurred. At Itaqueri/Lobo watershed and reservoir the reduction in precipitation is shown in Figure 4.

Since the reservo ir hydroelec tric power plant was in continuous usage in order to ma inta in hydropower production of $2 \mathrm{MW} / \mathrm{h}$ retention time was increased to 60 days instead of the normal 20 days period (Figures 5 and 6).

The overall consequence of these climatological/ hydrological events combined with the human activities such as hydropowergeneration was an increase in the nutrient in the water, deterioration of water quality and the growth of Cylind rospermopsis raciborskii in the reservoir; concentrations of chlorophyll a from 99 $\mathrm{mgxl}^{-1}$ to $108,0 \mathrm{mgxl}^{-1}$ were determined. (TUNDISI, 2017). When compared with the data of Passerini (2010) that measured chlorophyll a values from $23 \mathrm{mgxl}^{-1}$ to $26 \mathrm{mgxl}^{-1}$ this shows the impact of the Cyanobacteria growth. Lower diversity of phytoplankton and zooplankton were measured also during the period of the bloom (OGASHAWARA et al., 2017).

Therefore the changes in climatological events, and the human uses of the water had as a consequence the presence of heavy blooms of Cyanobacteria and loss of diversity and feedback control systems in the reservoir. 

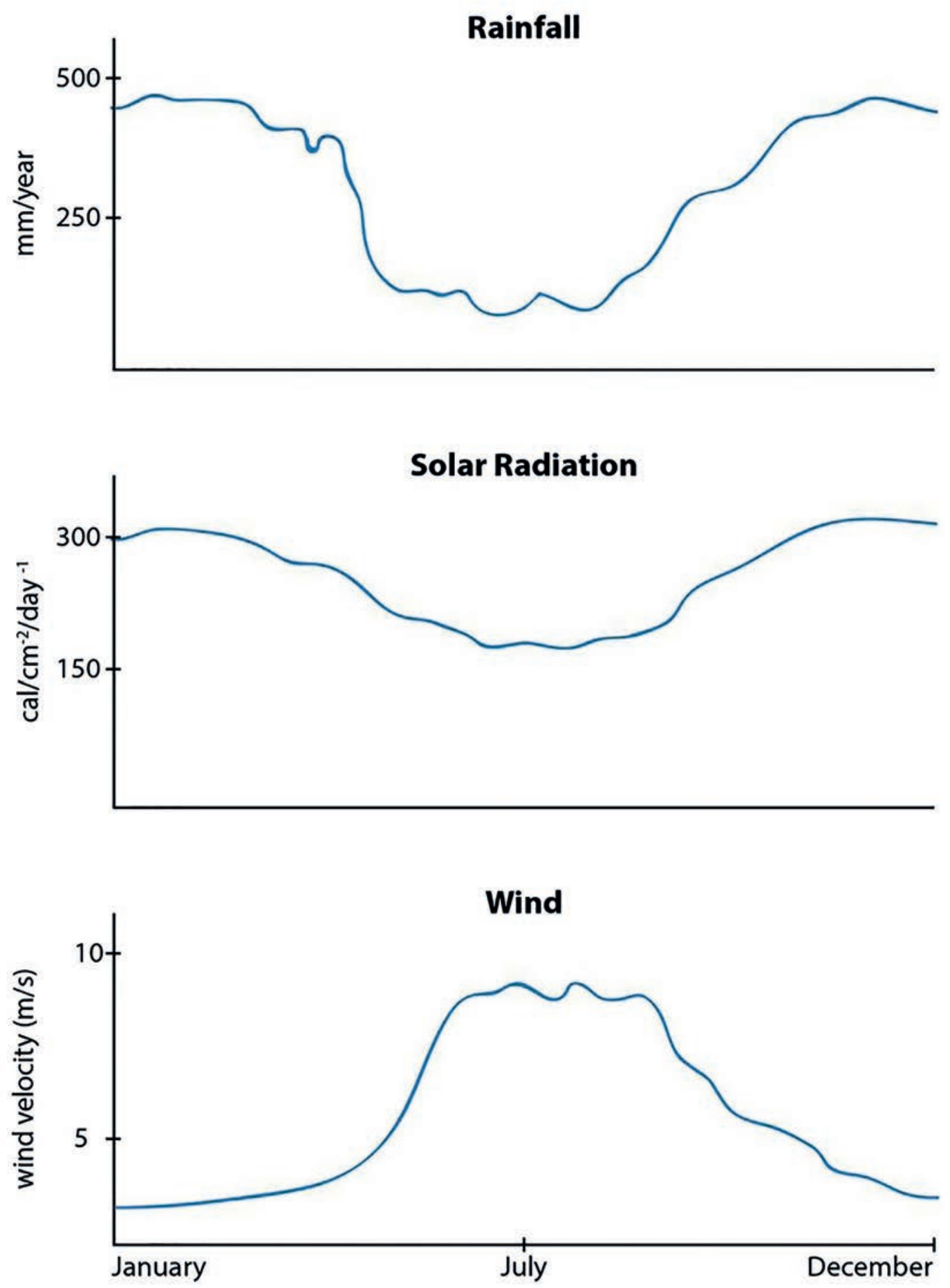

Figure 3 - The climatological onditions at Itaueri/Lobo watershed. Average values for 44 years (Source: TUNDISI et al., 2013). 
The Ecological Dynamics of UHE Carlos Botelho...

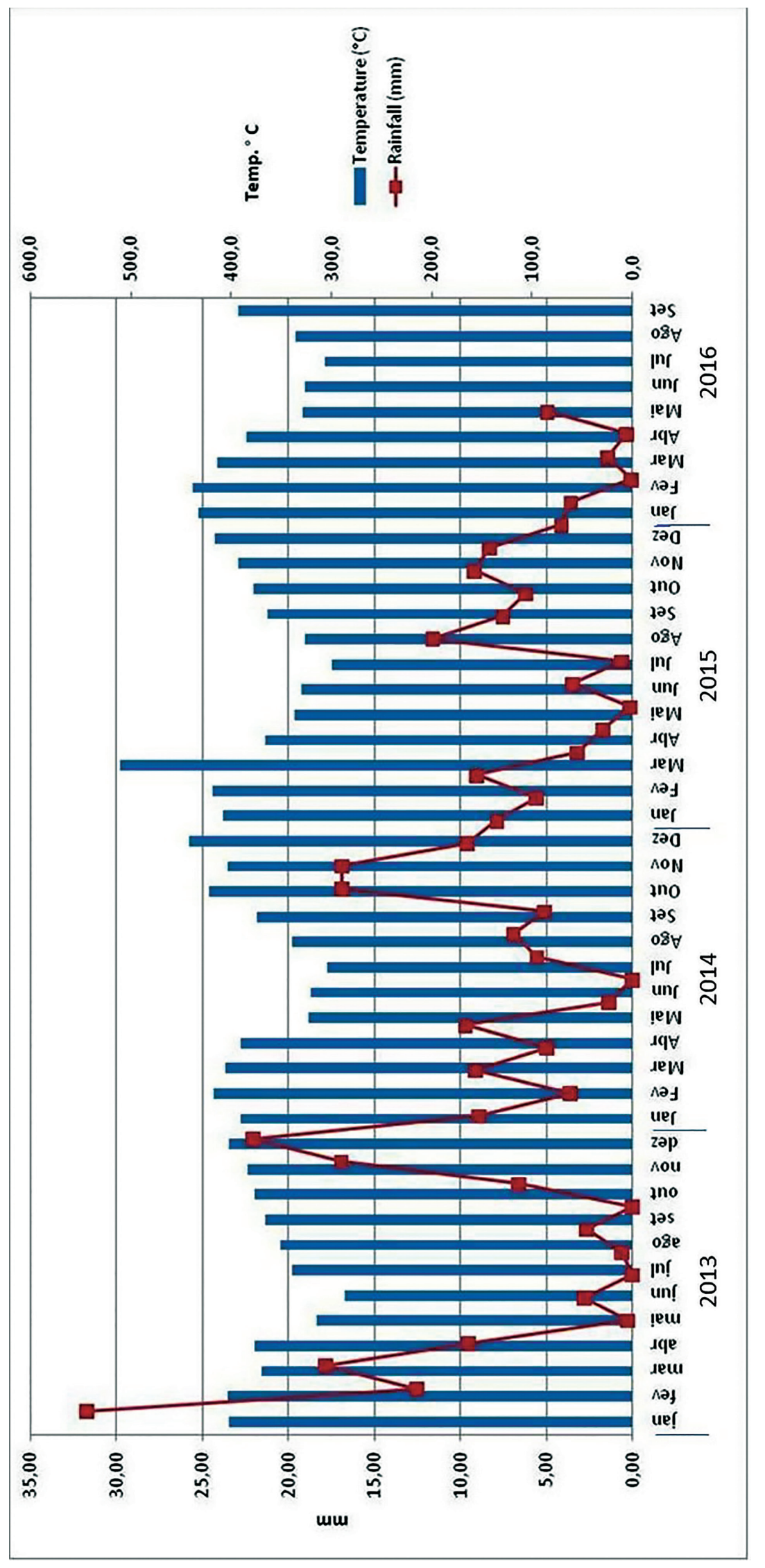

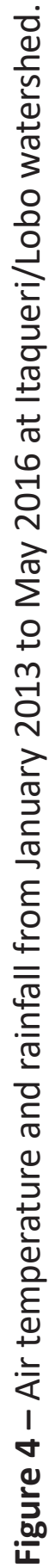




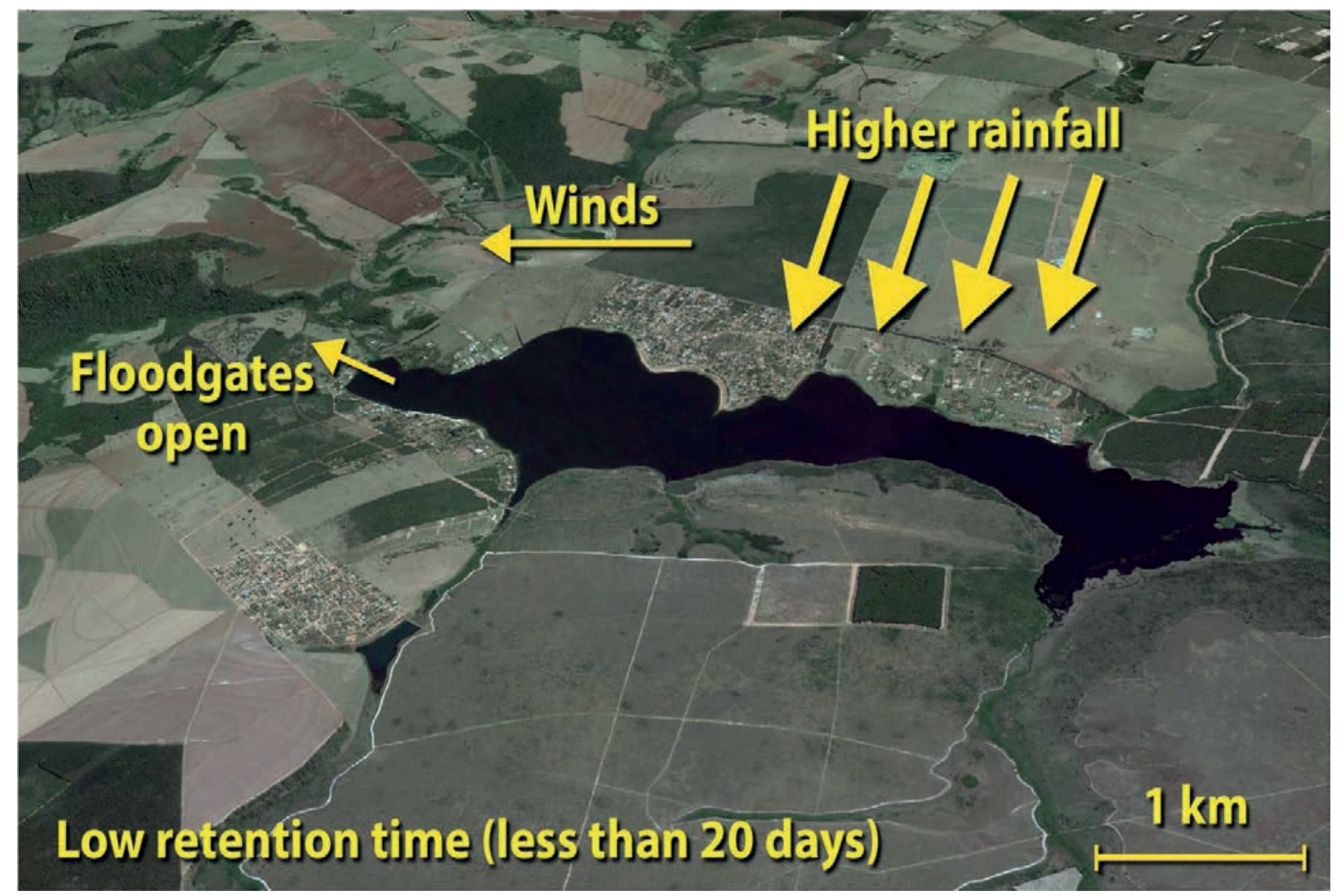

Figure 5 - Normal conditions at Itaqueri/Lobo watershed and reservoir.

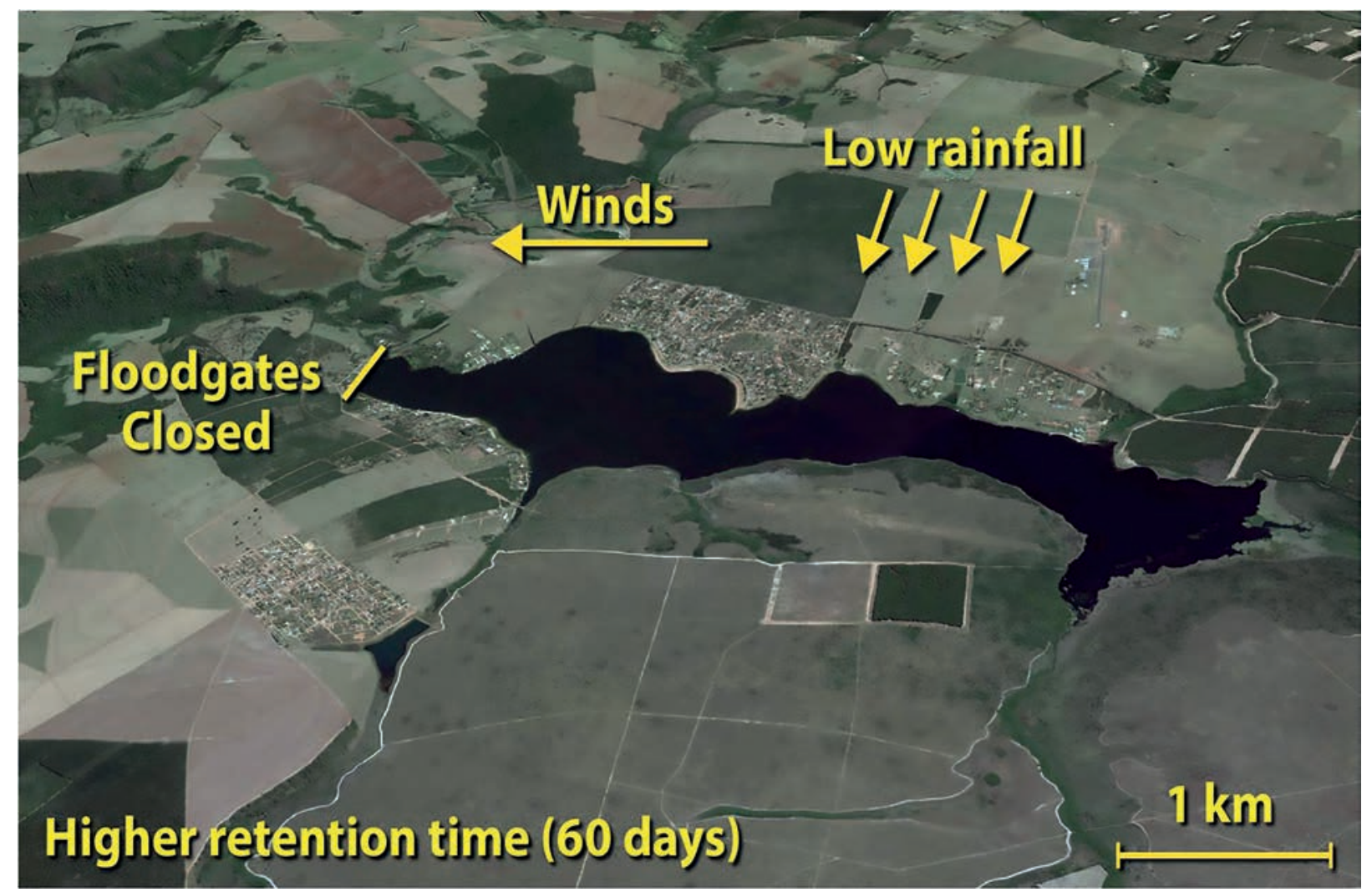

Figure 6-Low retention time and low rainfall during period of climatic changes at Itaqueri/ Lobo watershed and reservoir. 
The Cyanobacteria blooms linked to climatic changes present the following chara c teristic s and responses:

- Hydrologic changes;

- Nutrient concentration in the water; inputs; a vaila bility of nutrients increase;

- Water residence time (an increase enhances Cyanobacteria growth);

- Water mixing conditions (low mixing enhances Cyanobacteria growth);

- Higher surface water temperatures;

- Synergic activity of climatic change with anthopogenic nutrient enric hment.

(So urc es: SC HEFFER et al., 2001; PAERL; PAUL, 2012; WILSO N; SARNELLE; TLLMANS, 2006; WAGNER; ADRIAN, 2009).

\section{Dicussion}

In the search for funda mental mec ha nisms that drive the structure and function of ecosystems, it is necessary to understand the role of the forcing function that are the key components of ec osystems dyna mic s.

In the case of Lobo/Broa resenoir climatological/hydrological forcing functions are the ma in drivers of the reservo ir dyna mic processes related to biologic al, chemic al and physical responses. As stated by Kitchell et al. (1988), a major effort should be directed to understand the relationship between spatial/temp oral relationships the response and the interactions of a quatic communities.

Lobo/Broa reservoir has two compartments distributed spatially in the horizo ntal axis: the upper region, a wetland dominated by aquatic macrophytes with high concentration of organic matter in the waterand in the sediment; the lower region, the largest volume of the reservoir, turbulent, well mixed with predominance of phytoplankton as primary producerand a oxidized sediment due to continuous vertic al mixing (TUNDISI, 2017).

The ecological dynamic s of the reservoir is dependent of this horizontal gradient from the upper region to the dam site the vertical mixing promotes perma nent instability, full oxyg enation of the water column.

As for the temporal dynamics two ma in forcing functions a re present in the reservoir: precipitation in the summer and wind during the winter. These two forcing functions establish the horizontal and vertical pattems of circulation in the reservoir.

As demonstrated by Grana deiro Rios (2003) Lobo/Broa reservoir respond rapidly to the climatological forcing functions such as wind and precipitation. Low retention time (approxima tely 20 days) in norma I clima tological periods, controls the vulnerability to extemal fluxes of nutrients and suspended material loads. As disc ussed by Straškraba (1999) retention time is a key factor in the ecological dynamics of the reservoirs. The wetland at the upperportion of the reservoir is a lso an important controlling factory since it functions as a buffer compartment retaining nutrients, and suspended matter (TUNDISI; MATSUMURA-TUNDISI, 2013). 
Changes in this climatologic a I and retention time conditions promote changes in the response of the reservoir. It must be emphasized that during the period of studies the reservoir showed very much predictable responses in terms of phytoplankton biomass and composition and zooplankton composition and suc cession. (TUNDISI; MATSUMURA- TUNDISI, 2013).

During 2013 and 2014 the forcing function dynamics changed. Lower precipitation lead to lower volume of the reservoir. Also a highersurface water temperature occurred ( $2^{\circ} \mathrm{C}$ above average surface water temperature of 45 years). Higher retention time (approximately 60 days and not 20 days), higher nutrient concentration, presence of an inva sive species Cylind ro spermo psis ra ciborskii, of unknown origin produced drastic changes in the composition of phytoplankton community (from diatom/ Chlorophyte to dominance of Cyanobacteria). Lower diversity of phytoplankton and very high chlorophyll concentrations (80-120 mg $\times \mathrm{I}^{-1}$ ) demonstrated the change in the ecologic al dyna mic s (OGASHAWARA et al., 2017). Several species of zoopla nkton were not found at this stage.

The loss of control and feedback systems in related to abrupt changes in the forcing functions. The resilience of Lobo/ Broa reservoir was due to the stability in the clima tological forcing functions and in the long term stability of the retention time. Once these conditions were lost the resilience was a lso lost. A major change in the forcing functions promoted a new step in the organization and ecological dynamic s of the reservoir. This the "tipping point concept" applied to Lobo/Broa reservoir showed a change of status, a loss of resilience and feedback controls and a lower biodiversity. The links of the global expansion of harmful Cya nobacteria with climate change are at present well doc umented in several public a tions (PAERL; HUISMAN, 2008; PAERL; PAUL, 2012).

Mass development of Cyanobacteria inc rea ses turb id ity, restric ts ligh penetra tion; numerous planktonic species of cyanobacteria produce toxic peptides and alkaloids, that can produce neurological impairment, skin disea ses and even death (CHORUS; BARTHRAN, 1999).

Global wa rming produce hydrologic changes affecting the physical-chemical environmental and biological processes such as metabolic growth rates and bloom function. (PAUL, 2008) Higher tempera tures promote cyanobacterial growth. Global waming and changes in climate affects intensities, duration of precipitation and droughts with a consequence of inc reasing cyanobacteria dominance.

The effects of extensive Cylind rospermopsis raciborskii growth at Lobo/Broa reservoir showed strong interference with multiple uses such a s: rec rea tion, to urism, a quatic sports, fisheries.

In order to a chieve a better control of the waterquality and reduce the impact of changes in the climatological forc ing 
functions it is necessary to better control human activities in the system. Fisheries, recreation, aquatic sports have to be controlled in order to reduce nutrient point and non point sources, and avoid eutrophication. Also the deforestation process should be stopped; thus a improvement of the control of impact on now point sources should be expected.

The "tipping point concept" applied to Lobo/Broa reservoir ecosystem could be also applied to other reservoir/lake ecosystems of tropical and subtropical latitudes. When we learn more about the general mechanisms that drive the structure and functions of ecosystems, and regulate theirfunction, we are prepared

\section{References}

CHORUS, I. and BARTRAM, J., 1999. Toxic Cyanobacteria in Water. E \& F Spon, London.

EDMONDSON, W.T., 1994. What is Limnology. In: Limnology Now: A Paradigm of Planetary Problems. R. Margalef (Editor), pp. 547-553. Elsevier.

GRANADEIRO RIOS, C.M.M., 2003. Modelagem de Circulação de um Reservatório Tropical polimítico. Tese de Doutorado. UFSCar, 59 p.

KITCHELL et al., 1988. Epistemology, Experiments and Pragmatism. In: Carperter, S.R. (Editor). Complex interactions in lake communities. pp. 263-280. Springer Verlag.

MARENGO, A.J. et al., 2015. A seca e a crise hídrica de 2014-2015 em São Paulo. São Paulo. Revista USP, no. 106, pp. 31-44.

MARGALEF, R., 1966. Perspectives in Ecological Theory. University of Chicago Press. The Chicago series in Biology. $111 \mathrm{p}$. to promote a "big picture" that will emerge, applied to many ecosystems we can resolve and/or understand complex problems and intera ctions (KITC HELL et al., 1988). These complex interactions involve multiple spatial and temporal scales, with biogeochemical, chemical and physical responses. Thus the exemple of Lobo/Broa reservoir should be useful as study case for other lake/ reservoir ec osystems.

\section{Acknowledgements}

The authors acknowledge the support of FAPESP-PELD (Process 2012/51502-3) for this project. CNPq-PELD program (Process: 441564/2016) is a lso gra tefully acknowledged.
OGASHAWARA, I., CURTARELLI, M.P., STACH J.L. and TUNDISI, J.G., 2017. The use of remote sensing as a toll for water governance: study case of an algal bloom at Lobo-Broa reservoir Itirapina, Brazil, In: Justin A. Daniels (ed.). Advances in Environmental Research, vol. 61, pp. 131-160.

PAERL, H.W. and Paul, V.J., 2012. Climate Change: links to global expansion of harmful cyanobacteria. Water Research. vol. 46, pp. 1349-1363.

PASSERINI, M.D., 2010. Influencia das frentes frias nos mecanismos de funcionamento da represa UHE Carlos Botelho (Lobo/Broa) - Itirapina, SP, dos pontos de vista fisico, quimico e biologic. MSc thesis, Universidade Federal de São Carlos. 111 p.

PAUL, V.J., 2008. Global warming and cyanobacterial harmful algal blooms. In: Hudnell, H.K. (Ed.), Cyanobacterial Harmful Algal Blooms: State of the Science and Research Needs. Advances in Experimental Medicine and Biology, vol. 619. Springer, pp. 239-257. PAERL, H.W. \& HUISMAN, J., 2008. Blooms like it hot. Science, vol. 320, pp. 52-58. 
SCHEFFER, M., STRAILE, D., VAN NES, E.H. and HOSPER, $H ., 2001$. Climatic warming causes regime shifts in lake food webs. Limnology and Oceanography, vol. 46, pp. 1780-1783.

STRAŠKRABA, M., 1999. Retention time as a key variable of reservoir limnology. pp. 385-410. In: Tundisi, J.G. and Straškraba, M. (eds.). Theoretical reservoir ecology and its applications. Brazilian Academy of Sciences, International Institute of Ecology, Backhuys Publishers. 585 p.

TUNDISI, J.G. and MATSUMURA-TUNDISI, T., 2013. The ecology of UHE Carlos Botelho (Lobo/Broa reservoir) and its watershed S. Paulo, Brazil. Freshwater Reviews. vol. 6, pp. 75-91.

TUNDISI, J.G. et al., 2015. A bloom of Cyanobacteria (Cylindrospermopsis raciborskii) in UHE Carlos Botelho (Lobo/Broa reservoir): a consequence of global change? Braz. Journ. of Biol. vol. 75, no. 2, pp. 507-508.
TUNDISI, J.G. and MATSUMURA-TUNDISI, T. 2016. Integrating ecohydrology, water management, and watershed economy: case studies from Brazil. Ecohydrology \& Hydrobiology, vol. 16, pp. 83-91.

TUNDISI J.G., 2017. Pesquisas ecológicas de longa duração na Bacia dos Rios Itaqueri e Lobo e na Represa da UHE Carlos Botelho, (Lobo/Broa), Itirapina, Brazil. Relatório Final - Projeto PELD FAPESP 2012/51502-3. 82 pp.

WAGNER, C. and ADRIAN, R., 2009. Cyanobacteria dominance: quantifying the effects of climate change. Limnology and Oceanography, vol. 54, pp. 2460-2468.

WILSON, A.E., SARNELLE, O. and TILLMANNS, A.R., 2006. Effects of cyanobacterial toxicity and morphology on the population growth of freshwater zooplankton: meta-analyses of laboratory experiments. Limnology and Oceanography, vol. 51, pp. 1915-1924. 

Diatoms as Indicators of Anthropogenic Changes in Water Quality in Mucheke and Shagashe Rivers, Masvingo, Zimbabwe Bere, T.; Chakandinakira, A.T.

Analysis of Surface and Ground Water Samples in the Environs of Gold Mines Linked to Lead Poisoning Incident in Niger State, Nigeria Adio-Adepoju, A.A., Okiei, W.O., Ogunlesi, M., Ojobe, B.L., Ibrahim, G.O., Sobowale, O.S.

'Natal' Orange (Citrus sinensis L. Osbeck) Growing Simulation Model Under Climate Change Conditions Pereira, F.F.S., Queluz, J.G.T., González, A.M.G.O., Sánchez-Román, R.M.

Diversity of the Zooplankton (Alpha and Beta) in the Lentic Environment in the Miranda River Basin (MS, Brazil) Silva, W.M., Zanata, L.H., Roche, K.F., Silva, T.H.P.N., Souza, J., Severino, L.V., Duarte, J.D., Orikassa, T.N.

Impact Assessment of Water Translocation from the Tucutunemo River to Camatagua Reservoir (Aragua State, Venezuela) Matos, M.L., Guajardo, N.

Composition of the Characidae Family (Order: Characiformes, Pisces) in an Andean-Amazonian River, Case Study Hacha River Basin (Caquetá-Colombia) Remicio-Duque, J.H., Pelaez-Rodriguez, M., Gaspar, S.

The Fluvial Forests as Indicators of the Flow and Permanence of Water Zambiasio, V.A., Casco, S.L., Neiff, J.J.

Geographcal Distribution of Calanoida Species (Copepoda-Crustacea), at 22 UGRHi of São Paulo State - Brazil Matsumura-Tundisi, T., Tundisi, J.G.

Integrated Management Plan for the Itaquri Lobo Watershed and UHE Carlos Botelho (Lobo/Broa) Reservoir Tundisi, J.G., Matsumura-Tundisi, T., Tundisi, J.E.

Enhancing Methane Yields by Anaerobic Co-digestion of Sludge with Food Residues Aburawaa, A. A., Alrousan, D., Hayek, B.

Improving Global Wash Sustainability Graydon, $P$

System of Sustainability Batalhão, A.C.S.,

The Management of Water Resources as a Factor of Urban Resilience Corrêa, T.H.P., Teixeira, B.A.N.

Assessment of an in situ Real Time UV/VIS Based Spectrometry System for Chemical Oxygen Demand Measurement in a Wastewater Anaerobic Treatment Reactor Hernández. O.A.D., Lisboa, A.M., Cantão, M.P., Possetti, G.R.C., Aisse, M.M.

Real Time Monitoring of Water Quality in Supply Pipelines and Industrial Facilities Calvi, F.A., Ramos, G.P., Tundisi, J.G., Ghiglieno, F.G.

Preliminary Study of a Low-Cost, Easily-Implementable Alternative for Waterbody Restoration Bertho, G.G.

The Use of Geotechnologies In the Environmental Vulnerability Diagnosed in Sustainable Use Conservation Unit Siqueira, H.E., Pereira, G.T., Pissarra, T.C.T., Valle Junior, R.F., Santi, G. L. D., Campos, C.A.A.

World Bank Model Calibration Project with SWAT Methodology in Ochomogo River, Nicaragua (1st Stage) Cordero, M., García, A., Lacayo, N., Ramos, J., Yescas, L.

Using MQual 1.5 Modelling to Assess the Water Quality of a Subtropical Catchment Honda, F.P., Matsumura-Tundisi, T., Tundisi J.G.

The Ecological Dynamics of UHE Carlos Botelho (Lobo/Broa) Reservoir: Temporal Changes Tundisi, J.G., Matsumura-Tundisi, T.

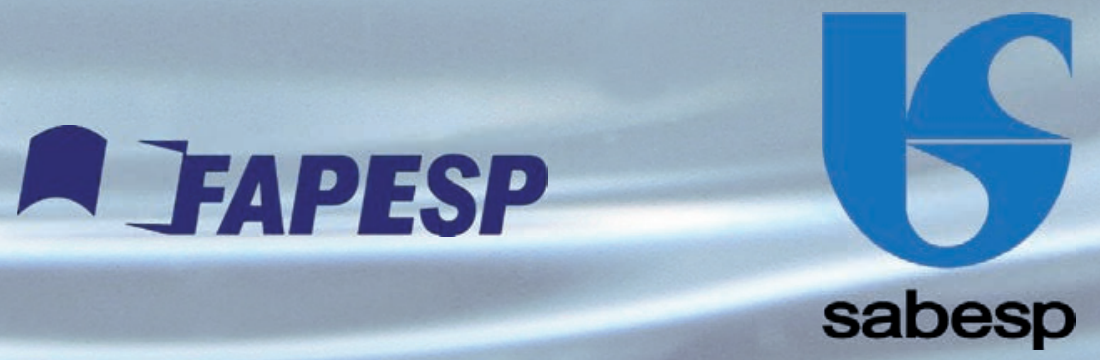

